\title{
The Politics of Identity: Emerging Indigeneity
}

Edited by:

Michelle Harris

Martin Nakata

Bronwyn Carlson

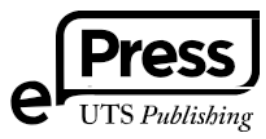




\title{
This edition published in 2013 by
}

\author{
UTSePress
}

University Library

University of Technology, Sydney PO Box 123

Broadway NSW 2007

Australia

ISBN: 978-0-9872369-2-0

\section{Edited by}

Michelle Harris, Martin Nakata \& Bronwyn Carlson

The essays in this volume are refereed. Copyright rests with the individual authors (C) 2013

No part of this publication may be reproduced in any manner whatsoever without written permission from the authors. Every reasonable attempt has been made to identify owners of copyright. Errors or omissions will be corrected in subsequent editions. 


\section{CONTENTS}

Contributors $\quad$ V

Acknowledgements $\quad$ xi

1. Indigenous Identities and the Politics of Authenticity 1 Michelle Harris, Bronwyn Carlson

\& Evan Te Ahu Poata-Smith

2. Emergent Indigenous Identities:

Rejecting the Need for Purity

Michelle Harris

3. Emergent Identities: The Changing Contours of

Indigenous Identities in Aotearoa/New Zealand

Evan Te Ahu Poata-Smith

4. On the Temporality of Indigenous Identity

60

Lewis R. Gordon

5. Emergent Indigenous Identities at the U.S.

Mexico Borderlands

T. Mark Montoya

6. Emerging and Submerging: Ebbs, Flows, and

Consistency in Expression of Indigenous Identity

Hilary N. Weaver 
7. Identity Politics: Who Can Count as Indigenous?

8. The New Frontier: Emergent Indigenous

Identity and Social Media

Bronwyn Carlson

9. Reading Radmilla: The Semiotics of Self

169

(Black and Navajo)

Ricardo Guthrie

10. Refusing Nostalgia:

185

Three Indigenous Filmmakers' Negotiations of Identity

Jeff Berglund

11. The Lions of Lesoit: Shifting Frames of

Parakyo Maasai Indgeneity

Kelly Askew and Rie Odgaard

12. Emerging Ethnicities and Instrumental

Identities in Australia and Brazil

Amanda Kearney

13. Resistance and Existence: North American Indigenous Humour of the $21^{\text {st }}$ Century

Daisy Purdy 


\section{CONTRIBUTORS}

Michelle Harris is an Associate Professor and Coordinator of the Graduate Program in the Department of Sociology and Social Work at Northern Arizona University. Her scholarly writings have focused on several areas including acculturation and stress among immigrant Americans, how racial discrimination affects the mental health and well-being of Blacks in the United States, and the effects of sociodemographic factors and stress on the mental health of Jamaican adults. She has also published in the area of critical race theory. Dr. Harris envisioned and convened the first Working Group on Emergent Identities (2009) when her research interest shifted to issues of identity construction and performance among Indigenous Peoples around the world. This edited volume is the product of scholarly conversations and papers developed and presented over the life of the Working Group.

Bronwyn Carlson is a senior lecturer in the Indigenous Studies Unit, Faculty of Law, Humanities and Arts at the University of Wollongong. Bronwyn's research focuses on a number of interrelated themes including the politics of Indigenous identity, with particular interest in what it means to identify as an Aboriginal person today focusing on what constitutes and is constitutive of Aboriginal identity in contemporary times. She was the first Indigenous person at UOW to be granted an Australian Research Council, Indigenous Discovery Grant. Her research project focuses is on how Aboriginal people represent and negotiate identity issues in the online space, more specifically in Facebook. Bronwyn is also one of the conveners of The Forum for Indigenous Research Excellence (FIRE) at the University of Wollongong. 
Martin Nakata is the Director of Nura Gili at the University of New South Wales. He also holds the title of Chair of Australian Indigenous Education. $\mathrm{He}$ is the first Torres Strait Islander to receive a $\mathrm{PhD}$ in Australia. His mother is an Indigenous person from the Torres Strait Islands, and his dad was born in Kushimoto-cho, Japan. His current research work focuses on higher education curriculum areas, the academic preparation of Indigenous students, and Indigenous knowledge and library services. He has presented eighteen plenary and keynote addresses at national as well as international conferences in ten countries, and published various pieces on Indigenous Australians and education in various academic journals and books in Australia and abroad. His book, Disciplining the Savages - Savaging the Disciplines, was published in 2007 by Aboriginal Studies Press.

Evan Te Ahu Poata-Smith, (Te Rarawa, Ngati Kahu) is Head of Indigenous Studies at the University of Wollongong. Prior to this he taught at the Auckland University of Technology and the University of Canterbury. More recently he was a Fulbright Scholarin-Residence at Northern Arizona University where he taught in the Applied Indigenous Studies and Sociology programmes. His research focuses on Maori political and social change. He is also one of the conveners of The Forum for Indigenous Research Excellence (FIRE) at the University of Wollongong.

Lewis R. Gordon is Professor of Philosophy, African American Studies, and Judaic Studies at the University of Connecticut at Storrs. He is the author of many influential books and articles, including An Introduction to Africana Philosophy (Cambridge UP), Disciplinary Decadence: Living thought in Trying Times (Paradigm Publishers), and the forthcoming No Longer Enslaved, Yet Not Quite Free: On Freedom, Justice, and the Decolonization of Knowledge (Fordham UP). For more information, please consult http://www.lewisrgordon.com/ 
T. Mark Montoya received his Ph.D. in Political Science with Distinction from Northern Arizona University (NAU) in 2009. He is currently a Lecturer in the Ethnic Studies Program, where he regularly teaches "Intro to Ethnic Studies," "Intro to Chicana(o)/Latina(o) Studies," and "Race, Identity and Film." Mark also serves on numerous

university, departmental, and student-support committees, and is the faculty advisor for 2 student organizations. His current research critically examines the development, use, and contestation of citizenship in U.S.-Mexico Borderlands.

Hilary N. Weaver, DSW (Lakota) is a Professor and Associate Dean for Academic Affairs in the School of Social Work, University at Buffalo (State University of New York). Her teaching, research, and service focus on cultural issues in the helping process with a particular focus on indigenous populations. She currently serves as President of the American Indian Alaska Native Social Work Educators Association. Dr. Weaver has presented her work regionally, nationally, and internationally including presenting at the Permanent Forum on Indigenous Issues at the United Nations in 2005, 2006, 2007, 2008, and 2013. She has numerous publications including the text, Explorations in Cultural Competence: Journeys to the Four Directions (2005) and is currently compiling an edited book, Social Issues in Contemporary Native America: Reflections from Turtle Island. Dr. Weaver has received funding from the National Cancer Institute to develop and test a culturally grounded wellness curriculum for urban Native American youth, the Healthy Living in Two Worlds program.

Ricardo Guthrie, Assistant Professor of Ethnic Studies at Northern Arizona University, examines political narratives of the Black Press and writes about cinema as cultural political artifacts. He is currently researching the life and influence of physician/publisher Dr. Carlton 
B. Goodlett and the San Francisco Sun-Reporter (1945-1966). His poetry and artwork can be viewed on the Museum of the African Diaspora's website:

http://www.iveknownrivers.org/

Jeff Berglund is a Professor of English at Northern Arizona University where he is a President's Distinguished Teaching Fellow and affiliate faculty with Ethnic Studies and Applied Indigenous Studies. He is the author of articles on the Navajo punk band, Blackfire, poet Simon Ortiz (Acoma Pueblo), poet Esther Belin (Navajo), and the pedagogy of American Indian literature. He is the editor and contributor of essays to Sherman Alexie: a Collection of Critical Essays (Utah UP, 2010) as well as the author of Cannibal Fictions: American Explorations of Colonialism, Race, Gender, and Sexuality (Wisconsin UP, 2006). His newest work in progress is Indigenous Pop: Contemporary Native American Music of the 20th Century (U of Arizona P).

Kelly M. Askew is Director of the African Studies Center and Associate Professor of Anthropology and Afroamerican/African Studies at the University of Michigan. Her works include Performing the Nation: Swahili Music and Cultural Production in Tanzania (University of Chicago Press, 2002); African Postsocialisms (coeditor, Edinburgh University Press, 2006); The Anthropology of Media (co- editor, Blackwell, 2002); and two documentary films: Poetry in Motion: 100 Years of Zanzibar's Nadi Ikhwan Safaa (70 min., 2012); The Chairman and the Lions (46 min., 2012)

Amanda Kearney is a Senior Lecturer of Anthropology at the School of Social Sciences and International Studies (SSIS) at the Faculty of Arts and Social Sciences, UNSW. She is the Convenor of the Global Studies major in the Bachelor of International Studies program. Her research specialty is Australian Indigenous anthropology, emerging ethnicities, intangible cultural heritage and 
the emotional geographies that accompany Indigenous homelands. In addition, she is currently undertaking a comparative analysis of emerging ethnicities amongst Indigenous youth in northern Australia and Afro-descendant groups in north eastern Brazil. By critically engaging with ethnic studies from an anthropological perspective, her research aims to define the quality and character of emerging ethnicities in post colonial and post imperial spaces.

Daisy Purdy is an Instructor with the Ethnic Studies and Sociology Department at Northern Arizona University. She received her Bachelor of Arts in Cultural Anthropology with minors in Psychology and American Studies from the University of New Hampshire prior to completing her M.Ed and Ethnic Studies Graduate Certificate at Northern Arizona University. Her current research addresses Native humor of North America as a tradition and survival strategy that challenges the dominant construct of stoicism. 



\section{ACKNOWLEDGEMENTS}

The editors wish to thank the Center for International Education at Northern Arizona University for its generous support. Dr. Harvey Charles, its director, believed in the vision and the importance of the work of the Emergent Indigenous Identities Working Group. The first and second meetings would not have been possible without grants from the Center. The editors would also like to acknowledge the support of the Department of Sociology and Social Work at Northern Arizona University who contributed to the first meeting in Flagstaff.

The Nura Gili Indigenous Programs Unit at the University of New South Wales also provided support for the project and hosted the second meeting of the working group in Sydney, Australia. We extend our deep appreciation to the Nura Gili staff.

This volume has been enduringly shaped by the contribution of several people. We wish to acknowledge the assistance of staff at UTS ePress and particularly for their timely and very helpful replies to all our questions. For prompt and professional copy-editing services we are grateful to Seema Mahanian.

We are grateful to the contributors of the volume, for their cooperation and for sharing their outstanding work. The involvement in the project has resulted in strong research collaborations that will continue well past this project. This is particularly the case for the contributors from Northern Arizona University and the University of Wollongong. 



\section{INDIGENOUS IDENTITIES AND THE POLITICS OF}

\section{AUTHENTICITY}

\section{Michelle Harris, Bronwyn Carlson \& Evan Poata-Smith}

The very question of Indigenous authenticity, as Jeffrey Sissons reminds us, "...has deep roots within colonial racism" $(2005,43)$. Racialisation and the practice of creating and imbuing racial categories with seemingly impermeable boundaries and indestructible meanings has, after all, underpinned a range of colonial practices from the systematic alienation of Indigenous land and resources to child abduction. Regimes of biological and cultural authenticity continue to shape state policies and practices that regulate the everyday lives of Indigenous people around the world. Indeed, in some contexts, expectations of Indigenous cultural purity or environmental naturalness exist alongside the imposition of varying degrees of blood quantum as criteria for citizenship, political recognition and access to resources and services.

Failure to express Indigenous identities in these terms often undermines the credibility of those individuals and groups who claim Indigeneity but resist such institutionally sanctioned identity categories. Although there are real material and non-material rewards associated with adopting Western stereotypes of Indigeneity that are recognised by institutions of the state and wider public, this is a double edge sword. As Sissons has noted, $(2005,39)$ "The operation of oppressive authenticity has been integral to the foundation of all settler nations and it continues to haunt the formation and implementation of their cultural politics. Included in the excluded middles of many post-settler states today are millions of Indigenous 
people variously described as 'half-castes', 'mixed-blood', 'urbanized', non-traditional' and 'westernized' - usually the majority of their Indigenous citizens." $(2005,39)$. In this way, a significant number of Indigenous people find themselves marginalised and dismissed as contaminated, impure and inauthentic.

It is not our goal in this volume to interrogate who legitimately has claim to Indigenous identity, how one should define "Indigenousness," or to document the identity making process among Indigenous peoples. Rather, it is our intent to explore what it means to claim Indigenous identity in contemporary times - whether one can meet state or community standards of "legitimate" Indigenous status. We also explore some of the ways individuals inhabit, negotiate and challenge existing definitions of "Indigenous identity," and how many others are creating new ways of "being" Indigenous.

\section{Identities: Relational and Contextual}

The concept of 'identity' has been deployed in such a myriad of different ways in the social and behavioral sciences, there has been a lack of consistency and clarity in its definition and application (Hall 1996). To some extent the wide variety of conceptualisations and definitions of identity simply reflect the concerns of different disciplinary paradigms with their own distinctive theoretical and empirical traditions. Conceptually, it is possible to make the distinction between notions of 'personal identity' and 'social identity' (Burke 2004). 'Personal identities' on the one hand are the selfdesignations and self-attributions that an individual enacts or asserts during the course of social interaction with others, and are essentially the meanings the individual attributes to the 'self' (Snow and Anderson 1987). The concept of 'social identities', on the other hand, provides a conceptual link between the individual's representation of 
'self and the social structures and groups in which the 'self' is embedded and ultimately constituted (Coupland 2007).

The concept of identity is both a relational and contextual construct. It is relational in the sense that it is not possible to hold a social identity all alone. All social identities are reflexively produced in interaction with others. The consequence of this interaction has been the production of 'representations' of other individuals and groups in terms of real or attributed differences, and of course for those that construct these representations, the establishment of criteria by which they represent themselves. While group identities must always be defined in relation to non-members of the group, the criteria for differentiation are contested and variable within groups themselves (Eriksen 2002). Indeed, there is seldom consensus about the norms, boundaries and world views that constitute the essence of a collective identity.

Identities are contextual in the sense that they are constituted differently in different historical and cultural contexts. In this way, identity is "...a socially constructed, variable definition of self or other, whose existence and meaning is continuously negotiated, revised and revitalized" (Nagel 1993, 2). The assumption that an individual possesses a unique core or underlying essence - the 'real me' - an authentic identity that is coherent and remains more or less the same throughout life, is a characteristic of essentialist arguments about identity. Rather than represent the "self" as a unified, fixed and unchanging construct, the chapters in this volume show how our notions of "self" are the product of a range of shifting and diverse social and cultural categories and identifications that are rarely stable. While obviously a repository of distinct individual and collective experiences, identities have been increasingly conceptualised as dynamic and shifting and as a process of becoming rather than being. 
Moreover, because our identities are formed and constituted in interaction with other people, they are fluid and evolve over the course of our lives. As Stuart Hall has argued, identity should not be theorised in terms of a "...stable core of the self unfolding from beginning to end through all the vicissitudes of history without change" (Hall 1996, 3).

More recent approaches have tended to treat identities as discursive resources. To have an identity, as Stevenson notes, is “...to be able to tell a story about the self and related communities. An identity is like a narrative that has to be constantly retold and reformulated in the light of new circumstances" (Stevenson 2006, 278). And while this discursive element to identity defies fixedness, and by definition is emergent, it does not imparts agentic power. Discourses are inert and by definition cannot possess agency and the capacity to act in the world. Of course, as Bob Carter notes, “...there are ways in which discourses can be said to condition and constrain what actors may say and do, but they cannot 'mobilize' or 'signal' or 'set boundaries' or 'prevail over'. All of these elements require intentionality and reflexivity - and, of course, discourses possess neither of these qualities" (Carter 2000, 48). It is important to emphasise, therefore, that it is not discourses of identity that impose particular interpretations of authenticity on individuals and groups, but social actors. The tensions between actors, and the particular discourses they articulate, are concretely negotiated in particular historical settings.

This last point is one of the conceptual cornerstones of this volumehuman actors deliberately and intentionally act out their identities in ever-changing ways as a consequence of the social relations and settings in which they find themselves. Identity, we contend, is a product of both agency and structure. While institutionalised forms of social conduct place limits on our autonomy, social life is both 
enabling and constraining. Social actors are also creative agents who attempt to construct their own sense of social identity and may challenge (or not) the prevailing social constraints and social structures. Nevertheless, social actors do not do this in circumstances of their own choosing. As Peter Berger has argued, social identities are "socially bestowed, socially sustained and socially transformed" (Berger 1963, 98).

\section{Emergent Indigenous Identities}

Indigenous identities are reflexively produced and depend as much upon the recognition of others as they do on the self-designations and self-attributions we assert during the course of social interaction with others. Rather than constituting a unified, fixed and unchanging construct, Indigenous identities are, therefore, always in flux; they are a response to shifting and diverse social and cultural categories and identifications that are rarely stable. In this sense, Indigenous identities are emergent; a process of becoming rather than being.

Indigenous identities not only develop from the constant ebb and flow of interactions between individuals and others, those interactions are frequently sites of contestation. Individuals laying claim to particular identities may find that others challenge those claims. The evaluation of others may be accepted or rejected by the individual, but it is in this context that claims and counter-claims about indigenous identities emerge. In this sense, the negotiation and renegotiation of indigenous identities involves claiming and resisting identities from within a set of prevailing discourses about the authenticity of particular indigenous categories. The social actors that articulate these discourses are themselves, of course, embedded in unequal sets of social, economic and political relations. As a result, these narratives about who should count as indigenous have conflicting political implications for different groups of indigenous people in the present 
especially given the increasingly diverse circumstances in which indigenous people now find themselves.

Indeed, colonial processes and practices have fundamentally transformed (and in some cases severed) the relationships that indigenous people have to place and to kin in a variety of ways. Some claims to indigenous identity align closely with the notions of biological and/or cultural authenticity that are so powerfully entrenched in institutional practices and the public consciousness. There are real material and non-material rewards for those and who can perform this indigenous 'otherness' in visible ways. In other cases, colonialism has restructured indigenous communities to such an extent that many individuals only become aware of their indigeneity later in their lives. Overtime, many have sought to re-establish those social and cultural connections. Identifying as indigenous, however, is not a straight-forward process and requires navigating particular narratives of belonging and discourses about what constitutes an 'authentic' or 'traditional' indigenous identity. If one cannot "be" in the right way, does one get to "be"? It is also important to recognise that many indigenous people, finding themselves caught once again in a binary not of their own making, continue to vigorously resist institutionally sanctioned identity categories viewing the preoccupation with notions of indigenous authenticity as racism and primitivism in disguise.

Identities, whether personal or collective, are inherently political. The politics of identity can involve the construction, reconstruction or disruption of notions about what it means to claim particular identities, or the creation or recreation of meanings attached to themespecially if these efforts are attempts to shift power relations within or between groups. Often, it is thought that the social, economic or resource stakes are much higher when out-groups (indigenous and 
non-indigenous) interact, but differential access to power occurs within and among indigenous groups.

The chapters in this volume explore some of the critical issues that impact on our understandings of indigeneity. They take the position that while identities are not fixed and immutable, nor can they be simply dismissed as an ideological fiction; they have real-life meaning and consequence. Indeed, it is clear that identities constitute significant modes through which people continue to experience, understand and explain the world around them. Therefore, identities, we believe, while socially and historically situated, are open to individual interpretation as to their usefulness and meaning at a particular point in time, and, as such, the political implications of a particular identity are not fixed or generalisable. Having said this, we do not mean to imply that we think indigenous identity is a kind of essence. Rather, we see it as a social fact, a knowledge system, a social location and an important factor in social relations - social relations that are ultimately political in nature!

\section{The Working Group on Emergent Indigenous Identities}

In 2010 a group of international scholars gathered at Northern Arizona University for the first working group discussing the topic of 'emergent indigenous identities'. The majority of members of the working group identified as indigenous to various geographical locations, identifying as Aboriginal, Torres Strait Islander, Maori, Mexican, Native American and Inuit. As culturally appropriate to many of the indigenous participants, presentations followed after recognition of ancestors, kin and country. These cultural acknowledgements included various languages (including English) and at times artifacts and images. After the formal proceedings were done with, discussion arose about the performitivity of indigeneity. One member of the group spoke about the anxiety she felt giving her 
presentation, as she was not wearing a necklace, which is specific to her people/culture. She commented that the necklace when worn signified to others her indigeneity and membership of a specific cultural group. The indigenous members recalled various experiences where they felt the need to perform or overly perform their indigeneity to ensure recognition of their identity.

The focus of the working group was guided by the following questions: Are emergent identities - new constructed identities that emerge as a function of historical moment, place and social forces"legitimately" available to groups such as those who claim Indigenous/Aboriginal/First Nation status? If so, what forces help to forge these identities? What are the ways in which these identities are performed throughout the world among indigenous groups? What are some of the challenges (both from outside and within groups) that indigenous individuals face as they negotiate the fine line between "authentic" cultural expression and new emergent identities? How do claims to multiple racial or ethnic identities affect one's emergent indigenous identity? The 'working group' is unique in that it is an international, multi disciplinary cohort coming together to "open up" the conversation about emergent indigenous identities in myriad ways so that we can begin to understand both the breadth and depth of this important topic.

This edited volume is the result of the collaboration of the participants of the working group.

\section{References}

Berger, P. (1963), Invitation to Sociology. A Humanistic Perspective. New York: Anchor Books.

Burke, P.J. (2004), 'Identities and Social Structure: The 2003 CooleyMead Award Address', Social Psychology Quarterly 67: 5-15. 
Carter, B. (2000), Realism and Racism: Concepts of Race in Sociological Research, London: Routledge.

Coupland, C. (2007), 'Identity: the Management of Meaning' in Ritzer, George (ed.), Blackwell Encyclopedia of Sociology, Oxford: Blackwell Publishing.

Eriksen, T.H. (2002) Ethnicity and Nationalism (2 ${ }^{\text {nd }}$ ed.), London: Pluto Press.

Hall, S. (1996), 'Introduction: Who Needs Identity?' in Hall, S. and du Gay P. (eds.), Questions of Cultural Identity, London: Sage Publications.

Nagel, J. (1993), 'Constructing ethnicity: creating and recreating ethnic identity and culture', in Yetman, N. (ed.), Majority and Minority: The Dynamics of Race and Ethnicity in American Life, 6th ed., Boston, MA: Allyn and Bacon.

Sissons, J. (2005), First Peoples: Indigenous Cultures and Their Futures, London: Reaktion Books.

Snow, D.A. \& Anderson, L. (1987) 'Identity Work Among the Homeless: The Verbal Construction and Avowal of Personal Identities', The American Journal of Sociology, Vol. 92, No. 6. (May, 1987), pp. 1336-1371.

Stevenson, N. (2006), 'Identity', in Turner, B.S. (ed)., Cambridge Dictionary of Sociology, Cambridge: Cambridge University Press. 


\section{EMERGENT INDIGENOUS IDENTITIES: REJECTING THE NEED}

FOR PURITY

\section{Michelle Harris}

In November 2009, a colleague sent me a CNN.com story about 'New Jews' - those who were exploring ways of accessing, understanding, and performing their identities as contemporary Jews. "It's true, for the first time in thousands of years that we can build the identities we want," one interviewee said, as the author highlighted ways that younger believers expressed their Jewish-ness, including tattooing Stars of David on their chests and performing punk-rock renditions of Jewish prayers (Ravitz 2009).

The article illustrated something which had recently captured my imagination, but the articulation of which eluded me: that contemporary indigenous identities can be "new" even as they are rooted in the ancient - a paradox if ever there was one. It forced me to delve deeper into my thinking about a term I had been using 'emergent' - and I began to see it as a space indigenous peoples carve out to be who they are. It is a complex space informed by historical moments, place, social forces, and the everyday of their lives. Of course, to claim Indigeneity is to self-consciously recognise that certain cultural "traits" (such as language, religion, ancestry) are important emblems in representing one's self, and in mobilising these emblems as signifiers of belonging, one is, in part, making a political statement of solidarity with others who also identify as indigenous (DeVoss 1995; Levi \& Dean 2003).

Both those who claim indigenous identity and outsiders often seem to fall into a trap of paradoxes - acknowledging complexity on the one 
hand, while reifying notions of 'tradition' and 'authentic cultural expression' as the core features of an authentic indigenous identity on the other. Of course, to claim difference is to eschew simplicity, or at least, straightforwardness - a condition that seems suited to being able to name and define that which constitutes the authentic. Authenticity also connotes a hegemonic state - one that is over-arching and predominant. Yet, scholars of indigenous identity challenge the notion of a hegemonic indigeneity, especially when the claimants range from those who were born to and are historically rooted (socially and culturally) in the practice of their identity, those who come to a knowledge of this identity status later in their lives, and those who may have been cut off from cultural or social institutions that offer opportunities and constraints that define and outline the parameters of how to 'be' indigenous. If one cannot 'be' in the right way, does one get to 'be'?

In this chapter, I want to rearticulate contemporary indigenous identity (primarily as it relates to those people in the latter group who face the challenge of accessing and claiming "authentic" indigenous identities) as an emergent phenomenon and in a way that is free of cultural essentialisation. I want to highlight agency, or the 'emergent' in identity formation and to recognise how positionality - or where we are in the social order - further complicates how identities are enacted. Additionally, I will borrow from writings about the concept of the 'Creole' or 'Creolisation,' not to claim that Indigeneity is a form of the being Creole, but rather to illuminate how contemporary forms of being indigenous highlights cultural accretion or mixing.

\section{Moving Beyond the "Real" Indigene}

Two presuppositions frame identity politics around indigenous identity (Taylor 1994). The first has to do with the ideal of the 'pure', 
'authentic', or 'real'. Clearly articulated, the assumption is that a binary exists: one either displays an 'authentic' indigenous identity (which is essentially primordial and displayed in culturally appropriate ways), or one does not. The second presupposition is that if identity is real, then others will know it. In other words, it will be distinguishable, and if it is either unrecognisable or misrecognised, then it cannot be true. Therefore, those who perform Indigeneity are open to censure, rejection and exclusion from their communities especially if they deviate from or misrepresent what is thought to be the 'right' or 'real' way to do things. Of course, much of this realness is tied up in beliefs of tradition and authenticity. As Conklin (1997) points out, there is a great deal of symbolic capital that ensues from authentic performance, especially in the absence of group access to important economic and political resources. Who establishes the boundaries within which one must perform? Forces both from within and outside of indigenous communities seek to construct, define, name, and police indigenous identities, and in doing so, a constant battle ensues in the shifting sands on which the play for authenticity is performed (Ariss 1988; Bourdieu 1990; Ang 2001).

Paradies (2006) eloquently speaks to some of the pitfalls inherent in defining and regulating the identity formation and performance of Aboriginality in Australia. Others have echoed similar sentiments in relation to minority and indigenous peoples in other sites around the world. ${ }^{1}$ Ideas about the primordial nature of indigenous culture and ethnicity not only delimits its possession to those who can claim uninterrupted access to indigenous culture and identity through ancestry, but also creates a situation where many people may fall into a trap of idealising a mythologised and fetishised authenticity that is

\footnotetext{
${ }^{1}$ For examples see Gilroy 1993; Sylvian 2003; Anthias, 2001; Bruner and Kirshenblatt-Gimblett 2004; and Fiske 2006
} 
rooted in a tradition that has most likely been impacted by centuries of colonisation, conquest and/or outsider influence. I do not suggest that indigenous culture should not be named as such, that it does not exist, or that attempts to define, perform or celebrate such a cultural identity ought to be abandoned. Rather, I question the existence of a pure, singular, hegemonic form that unifies all individuals who claim indigeneity. Moreover, I contend that identity, rather than being expressive of a definable cultural tradition, is formative: it emerges from particular historical moments, experiences, relations, position with the social order, and from both the opportunities and constraints that govern our realities. This means identities are formative and constitutive, not merely reflexive (Hall 1989).

One of the most crippling problematics of the stricture of a pure cultural form is the assumption that 'culture' is ontological - and to the extent that it exists, it must do so in some true, identifiable dimension. This is illustrated in the very popular conception that indigenous peoples have a mystical and ancient, or as Goldie (1989) termed it, "prehistoric" tie to that which was (culture, land, behaviors), so as to make their existence today irrelevant. This irrelevance exists if one can make claim to accessing 'pure' forms of culture (which then has no true relevance in today's world), or if one claims Indigeneity but has no claim to land, 'pure' cultural traditions, or has recently claimed indigenous identity (no claims to ancient signifiers means your claim is irrelevant because you are not really part of the culture).

An indigene of today cannot then be the same as an indigene of fifty years ago, much less one who lived one thousand and fifty years ago. It also means one pure or hegemonic racial/ethnic/cultural identity is unlikely, though many in the same ethnic group may, for example, experience some similar events and realities at a particular moment. The diversity of subjective positions will result in a contested, 
contextual, situated, and nuanced sense of what it means to belong to a particular cultural tradition.

Out of necessity, especially in today's mobile world, it is also imperative to consider how diaspora, dislocation, and migration challenge notions of accessing and performing "pure" forms of culture, ethnicity, and identity, though our thinking and research often ignores these realities. Inherent in this is the problematic and taken-for-granted notion that culture (which is usually seen as elemental to identity) can remain free of influence from outside forces. In fact, literature on migration and identity often frames those who are not physically residing within culture-rich physical spaces as being between 'two cultures'. Further, these individuals may be researched in terms of assimilation and/or acculturation (vis-à-vis the receiving community), and the extent to which the culture of their ancestry is diminishing relative to that of 'mainstream' society (Back 1996; Sellers et al. 2007). In other words, the strictures of cultural absolutism suggests limited bounds - both physical and behavioral within which one can manifest authentic forms of cultural identity: a challenge to the reality of mobility, globalisation, and dislocation.

\section{Inventing Culture?}

In writing about the politics of identity that San communities in Namibia often negotiate, Sylvian (2003) describes a situation where non-San (in and outside of government) often hold the view that since many who claim San identity no longer live in traditional ways hunting and foraging for food versus working on farms or living in urban areas-the idea of the 'Bushman' is a fiction of Colonialism and capitalism. 'Modern Bushmen', therefore, are inventing or creating new identities as they go, and these constructions cannot be 'true' since they have left ancient ways of life behind. Of course, in the case of the San, rights to land and other resources if they are perceived to 
be authentically indigenous, are at stake. But, most importantly, their agency and autonomy in terms of living their identities in contemporary times based on the opportunities and constraints at their disposal, are also at risk. In some cases, 'traditional' communities are unavailable to the San because of colonial-era land grabs, intermarriage with non-San peoples, or the need to find paid work as a means of survival. The reality for those making such choices is that they are precluded from qualifying for official recognition since they no longer live in their 'traditional communities' where they practice 'traditional' culture.

In this specific case, and often, more broadly when indigenous identity is considered, culture is defined in limited ways. It is sometimes seen as some kind of emblem or practice associated with a group, as a worldview by which we make sense of our world (Mannheim 1929), or as Durkheim (1966) conceptualised culture: patterned ways of knowing and doing - so that culture acts as structure.

Of course, in the case of the San, Indigenous Australians, Maori, Native American, or any other indigenous or First Nation people, the notion of cultural identity becomes bound up in narratives of belonging to a place, an ancient time, and a static culture. Identity enactment is constrained by elements of essentialism fixity - narrowly defined standards of behaviors that are steeped in the 'ancient' and are never open to change. Nowhere in this conception are the realities of conquest and colonialism, alienation, violence, and all forms of degradation: mental, physical and cultural.

Bourdieu's (1990) conception of 'habitus' sees culture as performative, agentic, and emergent. A combination of artifacts, behaviors, and dispositions that emerge from social structures -habitus, by definition, cannot exist outside of history, experience, and individual 
dispositions. This form of culture is active and interactive. It incorporates and adopts that which operates outside of the individual, but it does not necessarily herald meaningful change to one's identity, intellect, or emotional adjustment.

If 'traditional' practices and cultural expressions of a particular (i.e. ancient) kind become insupportable, and others emerge in the fullness of time, are these new forms 'invented' or inauthentic? What happens to indigenous identity as it travels through modernity? At war are rigid, totalised, doctrinally based conceptions of what it means to be a real San/Indigene versus the fluidity and flux of performing identity that reflects the discursive elements of social reality and cultures that emerge as a result of time, place, and histories of conquest and oppression.

\section{Creolisation: A Cultural Form}

The term Creole emerged during the Colonial period to reference those offspring of Old World' individuals who were born and raised in New World societies. The word comes from the Latin verb creare 'to create.' By the 1600s in the Spanish and Portugese languages, forms of the word existed - criollo/crioulo - to mean those of mixed descent, or both black and European.

Like 'culture' the word went on to have many meanings, many of them laden with negative connotations. For example, Creole is often used in linguistics to mean a non-standard or broken form of a particular language that may be recognised today as a unique linguistic form - but none-the-less, one that had its roots in a previous mother tongue (Brathwaite 1971; Mintz 1971; Vaughan 2005). Another example comes from cultural theory. In tackling the identity dilemma of descendants of enslaved Africans and formally colonised 
peoples, cultural theorists of the last fifty years sought to escape the dialectic, racist boundaries inherent in categorising peoples (Stoddard and Cornwell 1999). Since racial mixing is a reality in most formally colonised populations, using terms like "hybrid" came into vogue when referencing these groups. Within the discourse of postcolonial and cultural studies, however, hybridity suggests some "pure" beginnings and the subsequent crossing of boundaries that then leads to a transgression. This transgression would then be called a "hybrid." Inherent in this conception is the dialectic that is at the heart of race we are either one or the other, and hybrids represent yet a third entity that is neither. Hybridity therefore cannot exist outside of meanings of what constitutes "purity" - and by extension, the impure or hybrid form. Creole as an analytic framework, therefore, acts as an intellectual corrective to the notion of hybridity because the assumption of nativity is inherent in its meaning. It is about how cultural and institutional forms evolve in a particular place and time, and from a particular ethos: that of colonisation, a slave plantation economy and the power and race dynamics that was unique to that setting. Creolisation as a discourse, therefore, is a dynamic process of intercultural fusion - its parts leading to a particular whole in a specific context. One is very much native to a place (and, by extension, to a historical moment) even as one's roots may hail from a local or cultural context which is far removed. To simultaneously 'belong' and 'not belong' challenges biologistic and essentialist notions of any identity designation.

Some scholars of Caribbean culture - a major geographic seat of Creole culture - argue that Creolisation as a theory of cultural and identity must necessarily reside within Creole peoples (Black/European) in the New World, that its explanatory power is diluted outside of that context, and that its ability to 'travel' to other regions and people is hampered by its specificity (Mintz 1971). That 
view is not uniform. Glissant (1989), for example, a Martinician scholar and novelist, extends the concept outside of racial boundaries to people everywhere. Because no culture can be free of outside influence, the most important feature of what it means to be Creole is the reality of a complexity of cultural forms that have evolved historically. This is not about the loss of culture. Rather, the evolutionary process represents an "interactional and transactional" process that forges a contemporary identity form from the reality of colonisation, conquest, and the meeting and mixing of different cultural forms (Barnabe et al., 1990, 891). This thinking liberates Creolisation from its rootedness in meanings associated with "race" and allows me to focus on the concept as a means of highlighting interculturation or cultural transformation through mixing - a concept at the heart of contemporary emergent indigenous identities.

\section{Emergent Indigenous Identities}

Thus far I have made an argument for the necessity to move beyond arguments for a real or "pure" indigenous identity. This kind of thinking embodies an essentialism that relies on notions of purity and separateness. Indigenous people within any particular ethnic group cannot constitute a monolithic entity. Multiple contemporary realities predispose and shape myriad experiences, which in turn, lead to socially heterogeneous and dynamic ideas of the self. Research on identity formation supports this notion.

Early sociological research on the self led Mead (1912, 1925, 1934), a social psychologist who during the first decade of the twentieth century, wrote about identity in terms of the "I" and "Me." $\mathrm{He}$ conceptualised these as a dynamic grounded self-formation made up in part of how others define us and also what we create on the way to answering the question of "who am I?" Identities are formed in 
relation to the ways people inhabit roles, positions and cultural imaginaries that matter to them, e.g., a singer, a mother, an Aboriginal, a Maori.

We act out these identities in the course of coordinated social activity and everyday encounters with others. A Meadian identity is a sense of oneself as an actor in the social roles and positions defined by a specific, historically constituted set of social activities. In this configuration, identities are understood to be multiple, and while some may be longstanding and enduring, others may be disposable and fleeting. Some are ascribed: they come about as a result of how others see us. All, however, are dynamic entities - open to growth and change. There were two important points in Mead's conception: firstly, that the self was a complex, emergent phenomenon continually produced in and by individuals in their interactions with others and with the material world, and secondly, that the social position and roles, cultural symbols and other resources found in the material world, provided both opportunities and constraints for self-making. In other words, cultural genres and artifacts are the means through which we act out and/or represent identity, and even more importantly, identities themselves are part of more encompassing cultural constructions.

This last point involving the issue of culture is an important one. In today's world, many lay claim to "global" or diasporic identities as a means of claiming a political space where, I believe, we want to tell a story that constructs a reality of transcendence and contestation, and thereby lodge a protest against the stricture that culture and identity suggests, and that is so often inherent in racialised discourse. Yet, to do this may land one in the trap of glossing over the cultural, hierarchic, and hegemonic practices that are so important to understanding the "space" we occupy in a society, and ultimately the leverage we have to perform our identities. 
The concept of an emergent indigenous identity honors this space. Inherent in the concept is the recognition of the fact that identities are comprised of multiple components including the social and the personal - or where we fit in the social order. I am going to call this positionality, and use it to mean the space we occupy at the intersection of structure (place in the social order) and agency (meaning making and practice). The concept involves the lived experience in which identification is performed as well as the subjective appraisal of one's worth and utility in particular settings.

This positionality is often manifested in narratives or disclaimers of belonging. These narratives reflect, I contend, the social and cultural milieu in which one operates and also the epistemological (knowledge) and ontological (being) contexts of one's life. So hierarchies and social positions are always shifting -an Indigene could be powerless in certain institutional contexts, but exert power in interaction with peers by belittling, or in another instance, holding a position of an elder statesperson. Both of these contexts position people differently and reflect the situated nature of claims and attributions and their production in complex and shifting locals. I want to note here (though I will not say more about it) the recognition of the complexity of positionality when one considers the interplay of the range of locations in relation to gender, ethnicity, national belonging, class and racialisation.

A dictionary definition might explain 'emergent' as a process of coming into being or becoming prominent. When coupled with the term identity and placed in the context of the preceding discussion, it emerges as an agentic and dynamic process that unfolds through social and cultural activities and relationships. An emergent identity is an evolving integration of the self and "other" (or what is outside the self) through participating in activities that give meaning to who 
we are. It becomes manifest in the context of personal, social and cultural influences.

Emergent identities accommodate interculturation: cultural transformation through mixing. There is often a critique of (loss of culture) or "deculturation" by the gatekeepers of "authentic" culture. There is nothing static or unchanging about indigenous cultures and therefore, indigenous identity. It, like every other culture, is fluid and must change and adapt over time. Can there be authentic culture? Moreover, to those who do not have the luxury of "authentic" modes of cultural expression, there really is no loss! Rather, it is accretion that occurs, or cultural enrichment. Of course, we must recognise that at the heart of this debate is the issue of (masked) power relations that raise critical questions about social location of those performing and reading the process of interculturation.

Emergent indigenous identities make room for those on the outside of the orthodoxy (or those, who by their very existence, are "Creole" per Bernabe et al.). They, too, are drawing on the complex cultural sources available to them. They are affirming their legitimacy through the production of intentionally mixed cultural forms. Some of these forms are deliberately created to express experiences and identity, and some have been imposed in that they have been passed down from generation to generation. In either case, those claiming indigenous identities do so in contemporary times using subjective symbols that announce their belonging to a particular community - one that is distinct from most "national" populations.

Finally, emergent identities recognise the performative nature of identity. It is discursive as well as a social reality, and any performance's endurance or demise will depend on either feelings of satisfaction (and the subsequent decision to continue an action), or 
appraisals of diminishing utility (and a decision to cease acting in a particular way). This element of enactment does not entail fixity or essentialism; rather, it speaks to the complex appraisals of costs and benefits that are the motivational heart of identity performance. Most importantly, performing identity highlights agency - the ability to act deliberately and purposefully.

\section{Conclusion}

To identify as an indigenous person, according to Levi and Dean, is to utilise an "idiom of social belonging" to a people whose "histories, habitats, and lifeways distinguish them from dominant "national" populations" $(2006,8)$. Yet, to do so often locks one into a trap of monolithic, fossilised, and essentialised characteristics of identity performance. In fact, claiming indigeneity often demands the demise of all other identity markers or positions and leaves individuals in the position of defending their performance of a "real" or "pure" form of this identity status. In this essay I have tried to problematise this tendency and to delineate the concept of emergent indigenous identities as a corrective. That which is emergent is in the process of becoming - a state which connotes growth and change. Sociohistorical conditions, ideological variations, and the personal ecologies of people's lives impact identity construction and lead to a diversity of interpretations of what it means to be indigenous.

Creolisation, as an analytical tool, offers us a way to understand emergent indigenous identity, not as a biologically rigid or culturally essential entity, but as an agentic, interactional, and adaptive response to the questions, "Who am I?" and "What does it mean to be 'me' as an indigenous person?" Emergent identities reject the necessity to access 'authentic' culture since, by its very definition, it is never available in this space and time. Moreover, these dynamic self- 
proclamations embrace interculturation - the cultural transformations that come via mixing. Most importantly, emergent indigenous identities must reject the notion that the 'new' identities are 'deculturised' or lacking in authenticity since that luxury of the authentic is not currently available. This is in no way loss; it is, in fact, cultural enrichment.

\section{References}

Anathias, F. 'New Hybridities, Old Concepts: The Limits of Culture'. Ethnic and Racial Studies 24, no. 4 (2001): 619-641.

Ang, I. On Not Speaking Chinese: Living Between Asia and the West. New York: Routledge, 2001.

Ariss, R. 'Writing Lack: The Construction of an Aboriginal Discourse' In Past and Present: The Construction of Aboriginality, edited by J.R. Beckett, 131- 146. Canberra: Aboriginal Studies Press, 1988.

Back, L. New Ethnicities and Urban Culture. London: UCL Press, 1996.

Bernabe, J., P. Chamoiseau, and R. Confian 'In Praise of Creoleness' Callaloo, 13, no. 4 (1990): 886-909. Translated by M.B.T. Jhyarr from E'loge de la Creolite. Paris: Gallimard, 1989.

Bourdieu, P. The Logic of Practice. Oxford: Polity Press, 1990. Brathwaite, E. The Development of Creole Society in Jamaica 17701820. Oxford: Clarendon Press, 1971.

Bruner, E M. and B. Kirshenblatt-Gimblett. 'Maasai on the Lawn: Tourist Realism in East Africa' Cultural Anthropology, 9, no. 4 (1994): 435-470.

Conklin, B. 'Body Paint, Feathers, and VCR's: Aesthetics and Authenticity in Amazonian Activism', American Ethnologist 24, no. 4 (1997): 711-37. 
Dean, B. and J. M. Levi. At the Risk of Being Heard. Ann Arbor: The University of Michigan Press, 2003.

Durkheim, E. The Rules of Sociological Method. New York: The Free Press, 1966.

Fiske, J. 'Boundary Crossings: Power and Marginilisation in the Formation of Canadian Aboriginal Women's Identities' Gender and Development 14, no. 2 (2006): 247-258.

Gilroy, P. Small Acts: Thoughts on the Politics of Black Cultures. London: Serpent Press, 1993.

Glissant, E. Caribbean Discourse: Selected Essays. Charlottesville: University of Virginia Press, 1989.

Goldie, T. Fear and Temptation: The Image of the Indigene in Canadian, Australian and New Zealand Literatures. Kingston: McGill-Queens University Press, 1989.

Hall, S. 'New Ethnicities.' Black Film, British Literature: ICA Documents 7, London: Institute of Contemporary Arts, 1989.

Manheim, K. Ideology and Utopia. London: Routledge, 1929.

Mintz, S. 'The Socio-historical Background to Pidginization and Creolization.' In Pidginization and Creolization of Languages, edited by Dell Hymes, 481-496. Cambridge: Cambridge University Press, 1971.

Paradis, Y. 'Beyond Black and White: Essentialism, Hybridity and Indigeneity.' Journal of Sociology 42, no. 4 (2009): 355-367. Ravitz, J. (2009). 'New Jews' stake claim to faith and culture.' CNN, October 30, 2009. Accessed November 30, 2010, Accessed November 30 , 2009, http://www.cnn.com/2009/LIVING/10/28/new.and.emergent.je ws/index.html

Sellers, S., F. C. Hiu Ha, and M. Harris. 'Theorizing heterogeneity: Social and Economic Well-Being of Native Blacks, AfroCaribbean and African immigrants in the US.' Research in Race and Ethnic Relations, 14, 287-305. JAI Press, 2007. 
Stoddard, E. and G. Cornwell. 'Cosmopolitan or Mongrel? Creolite, Hybridity and 'Douglarisation' in Trinidad.' Cultural Studies 2, no. 3 (1999):331-353.

Sylvian, R. 'Class, Culture and Recognition: San Farm Workers and Indigenous Identities.' Anthropologica 45, no. 1 (2003): 111 119.

Taylor, C. 'The Politics of Recognition.' In Multiculturalism: Examining the Politics of Recognition, edited by Amy Gutmann, 25-73. New Jersey: Princeton University Press, 1994.

Vaughn, M. Creating the Creole island: Slavery in Eighteenth-Century Mauritius. Durham: Duke University Press, 2005. 


\section{EMERGENT IDENTITIES: THE CHANGING CONTOURS OF \\ INDIGENOUS IDENTITIES IN AOTEAROA/NEW ZEALAND}

\section{E.S. Te Ahu Poata-Smith}

This chapter explores the changing contours of contemporary indigenous identities in Aotearoa/New Zealand. It challenges essentialist notions that Māori have “...singular, integral, altogether harmonious and unproblematic identities"(Calhoun 1994, 13). It will be argued that rather than conceptualising Māori identities as the continual transmission of fixed cultural essences through time, "being Māori” should be approached as part of a more discontinuous process in which culture and tradition are continually made and remade.

First, the chapter will present an overview of the way Māori identities are signified and constructed through various codes and everyday practices, so that what it means to be Māori varies across space and time. Indeed, it will be argued that Māori identities are “...renewed, modified and remade in each generation. Far from being selfperpetuating, they require creative effort and investment" (Eller \& Coughlan 1993, 188). indigenous identities in Aotearoa/New Zealand are also constituted amid a flow of competing cultural discourses about what it means to be Māori. These identities are the outcome of interactions that involve claims made by individuals and groups to particular identities (and in some cases the rejection of those identities), and the ascriptions made by others (both from outside and within indigenous communities). As such, the negotiation and renegotiation of Māori identities is a contested process. It involves claiming and resisting identities from within a set of prevailing discourses about the authenticity of particular indigenous categories. 
Next, it will explore competing ideas and dominant narratives about what being Māori is, or what being Māori ought to be. It will examine, in the first instance, the idea that Māori identities should be understood principally in terms of "whakapapa" (the genealogical connections of individuals and groups to particular ancestors). Is whakapapa a sufficient criterion for those identifying as "Māori"? How significant are other social and cultural factors? In the second instance, the chapter will explore the impact of doctrines of "race" and racial purity on historical and contemporary notions of Māori identity in Aotearoa/New Zealand. How has the idea that being "Māori" is principally a matter of blood quantum (and that, by extension, the essence of "Maori" identity is a discrete set of phenotypical charateristics) shaped both indigenous and non-indigenous understandings of Māori identity?

Thirdly, it will trace the evolution of a sense of Māori "ethnicity" that transcends disparate iwi and hapū based identities. ${ }^{2}$ To what extent has a more generic notion of "Māori culture" become a critical dimension of contemporary expressions of Māori identity? How have these ethnic representations of Māori identity been embraced or resisted? Finally, the chapter will examine the argument that Māori identities are exclusively iwi or tribal in nature. To what extent do iwi constitute the permanent, timeless entities that are so often represented in contemporary debates about 'traditional' Māori social structures? Do they constitute the only authentic expression of being Māori?

${ }^{2}$ Iwi, hapū and whānau are the basic social units of Māori society and are based on descent from common ancestors. The word 'iwi' (literally meaning 'bone' but often miss-translated as 'tribe') refers to the widest of possible descent categories. 'Hapū' (literally meaning 'pregnant') constitute narrower descent groups made up of related 'whānau' (extended family groupings). 
The social actors that articulate these discourses are themselves embedded in unequal sets of social relations. It is important to emphasise that Māori identities have been, and continue to be, negotiated and renegotiated in the context of the ongoing political, economic, and social subjugation of iwi, hapu and urban Māori communities. Furthermore, the state has long been involved in the regulation and monitoring of indigenous identities in Aotearoa/New Zealand. Indeed, state agencies have actively encouraged Māori to adopt particular ways of identifying by categorising indigenous communities into more administratively convenient and allegedly authentic groupings (Poata-Smith 2004). Failure to express indigenous identities in these terms may undermine the credibility of those individuals and groups who resist such state sanctioned identity categories. On the other hand, there are real material and nonmaterial rewards associated with adopting categories of Indigeneity that are recognised by institutions of the state.

Māori identities are also shaped and molded in the context of inequalities between Māori that exist within iwi, hapū and urban Māori communities. As is the case with many subcultures and identity groups, definitions of authenticity are highly contested (Peterson 2005). The political debates and controversies are wide ranging and they reflect the radically different ways Māori life experiences have been shaped through the complex articulations and interpretations of racism, colonialism, ethnicity, class, and gender. Given the inequalities of wealth and political power that are entrenched within contemporary Māori society, particular historical representations and interpretations of "authentic" or "traditional" Māori identity have conflicting political implications for different groups of Māori in the present. There are, as a consequence, intense struggles over who gets to define that authenticity in the first place. Clearly, particular 
definitions of what constitutes authentic Māori ways of living favour the interests of some members over others.

The state has not been neutral in the ongoing political debates and controversies about Māori identities. In recent years, the complexity and fluidity of Māori identities and indigenous social and political relations have often been translated to fit more simplified, static, and essentialised cultural paradigms. In this way, the state has tended to privilege the representations of authenticity articulated by the more powerful members of iwi, hapū, and urban Māori communities in shaping identity categories often at the expense of those Māori at the margins.

\section{The Concept of Identity}

Although there has been a "veritable discursive explosion" in the use of the concept of "identity" in the social and behavioural sciences, there has been a lack of consistency and clarity in its definition and application (Hall 1996). To some extent the wide variety of conceptualisations and definitions of identity simply reflect the concerns of different disciplinary paradigms with their own distinctive theoretical and empirical traditions. Nevertheless, the concept of "identity" has been deployed in such a myriad of ways, there is little agreement about the phenomena to which it might refer. As such, some scholars have argued that the concept of identity is so analytically loose and amorphous that it will never prove to be a reliable variable for the social sciences (Brubaker \& Cooper 2000). Others have attempted to develop greater analytical rigour and clarity by suggesting dimensions along which different meanings can be compared and contrasted (Hogg \& White 1995; Deauz 1996; Brewer 2001). 
While the diversity of Māori lived experiences is more widely acknowledged than it once was, there is a tendency, nonetheless, to fall back on reified and simplistic notions of tradition, language, and culture as constituting an unchanging "authentic" essence of Māori identity. Indeed, the underlying core of Māori collective identities are often characterised as if they are in some sense primordial or naturalistic and are frequently presented as being relatively unchanging and therefore transcending time and space. To some extent this response is understandable. As Calhoun has acknowledged, "When a particular category of identity has been repressed, delegitimated or devalued in dominant discourses, a vital response may be to claim value for all those labelled by that category, thus implicitly invoking it in an essentialist way" (Calhoun 1994, 202).

Indeed, more essentialist notions of Māori identity flourished with the rise of cultural nationalist strategies and the assumptions of identity politics as the dominant philosophical and political paradigm within Māori political movements from the late 1970s and early 1980s (Poata-Smith 1996). Cultural nationalist political ideology and practice rests explicitly on the assumption that there is an "essence" or set of innate and inherent characteristics that define Māori identity, and which have remained constant throughout history (see the discussion below).

While cultural nationalism is only one of a number of competing political ideologies that exist within the broader Māori political milieu, the representation of New Zealand history as an irredeemable clash of cultural identity based on underlying essentialist assumptions about Indigeneity have had a profound influence on contemporary debates about Māori identities.

Unfortunately, this has, all too frequently, gone hand-in-hand with the suggestion that those Māori that do not share all of these elements 
of culture, language, or tradition suffer some degree of deprivation or are inauthentic. Indeed, this points to one of the more problematic aspects of these essentialist conceptions of identity: that is, the tendency to posit one aspect of identity as the sole determinant constituting the social meanings of an individual's experience. Individuals, however, bear multiple identities. Māori life experiences, for instance, are also profoundly shaped by gender, sexuality, and class, among a host of other social factors. As such, Māori individuals have "...multiple intersecting social and identity attributes that help to comprise their self-identity" (Brekhus 2008, 1063).

Because of this, indigenous identity is best thought of as an ongoing social process rather than being a fixed property of an individual or group. At its core, this process involves a dialectical relationship between the way we attempt to present ourselves and the way that others regard us. In this sense, there is no external or objective source of validation, but ongoing identifying or positioning by social actors embedded in particular social systems ${ }^{2}$. The concept of identity deployed here, therefore, is not essentialist, but a strategic and positional. As Said $(1995,332)$ has argued, "Far from a static thing then, identity of self or of "other" is a much worked-over historical, social, intellectual, and political process that takes place as a contest involving individuals and institutions in all societies."

\section{Emergent Māori Identities}

For centuries Māori communities have communicated information about their identity, and their relationship to "space" and "place" in

\footnotetext{
2 See Hollway, W. (1984) "Gender Difference and the Production of Subjectivity" in Henriques, J., Hollway, W., Urwin, C., Venn, C. and Walkerdine, W. Changing the Subject, London: Methuen, pp. 227-263; Harré, R. and van Langenhove, L. (Eds.) (1999) Positioning Theory, Oxford: Blackwell.
} 
complex and dynamic ways. Their ongoing connection to a place of origin has manifested itself through complex forms of land tenure that embody the communities' changing material needs, land use patterns, belief systems, and governing structures (Jacobs \& Hirsh 1998). The use of the noun 'Māori' as a self-referential term and as a means to categorise and describe the indigenous inhabitants of New Zealand is, however, relatively recent in origin. ${ }^{3}$ As an adjective, the word "Māori" means "normal," "usual" or "ordinary" and was used historically to describe anything in its natural state. As an adverb, the word 'Māori' means "freely," "without restraint" and "without ceremony" (William 1992, 179).

Although there is some evidence that the term 'Māori' was in use prior to 1815 to describe the quality of being "native" or belonging to New Zealand, early European settlers, traders, and explorers invariably spoke of "Natives," "Aboriginals," or "Indians." These were, of course, well-rehearsed categories that had emerged as the lingua franca of European colonial encounters with indigenous peoples globally.

With the legal and statutory recognition of New Zealand as an independent sovereign territory outside British dominion in 1817, many colonial administrators, missionaries and settlers simply referred to the local inhabitants by the more generic label "New Zealanders". This became more problematic with the annexation of New Zealand as a formal British settler colony in 1840 and the subsequent rapid influx of predominantly British settlers. The term "New Zealander" would no longer remain the preserve of indigenous communities.

\footnotetext{
${ }^{3}$ Historically, “Tangata Māori” was a phrase used to differentiate human beings from supernatural beings.
} 
From the mid-nineteenth century, the word "Māori" was increasingly used as a noun to differentiate the indigenous inhabitants of Aotearoa/New Zealand from the new European arrivals (Williams 1971, 179). One of the earliest documented examples of the use of the word 'Māori' in this way, in written English, dates from the 1850 s. $^{4}$ In this sense, the notion of a "Māori race" or people co-existed with and eventually superseded other official British Colonial Office descriptors employed in the New Zealand context (although the more pejorative and widely used "Native" continued to be employed in official State business). In fact, it was not until 1947 with the introduction of the Māori Purposes Act that the Department responsible for the administration of indigenous affairs in New Zealand changed its nomenclature from the Department of Native Affairs to the Department of Māori Affairs.

Being "Māori" was, in a sense then, created through that very contact with members of European settler groups. It was a convenient category that did not require a more nuanced understanding of localised identities and relationships based around whānau, hapū and iwi. Since the nineteenth century, the term "Māori" has been invested with new meaning and significance. Indeed, contemporary Māori identities have been constituted amid a flow of competing cultural discourses about what it means to be a member of iwi, hapū and/or urban Māori communities. The negotiation and renegotiation of contemporary Māori identities is a contested process in the sense that it involves claiming and resisting identities from within a set of

\footnotetext{
${ }^{4}$ Cooper, G.S. (1851) Journal of an expedition overland from Auckland to Taranaki by way of Rotorua, Taupo, and the west coast undertaken in the summer of 1849-50 by his Excellency the Governor-in-Chief of New Zealand, Auckland: Printed by Williamson and Wilson, p. 204.
} 
prevailing discourses about the authenticity of particular Indigenous categories.

\section{Whakapapa}

Māori identities in Aotearoa/New Zealand have been, and continue to be, expressed principally in terms of "whakapapa" (the genealogical connections of individuals and groups to particular ancestors). Whakapapa not only refers to lines of descent that bind people to ancestors and to each other, but constitutes a framework that links human beings to the origins of the universe and all animate and inanimate phenomena. The notion of "whakapapa" (geneaology) may have been derived from the Māori verb to "place in layers" or "lay one upon another" (William 1992, 259). As Apirana Ngata $(1972,6)$ once explained it, whakapapa is "...the process of laying one thing upon another. If you visualise the foundation ancestors as the first generation, the next and succeeding ancestors are placed on them in ordered layers."

Those who trained as repositories of oral history could recite hundreds of names in interlocking genealogies. As Ballara (1991, 550551) notes:

Evidence exists that the most expert tohunga did have phenomenal memories... There is some evidence that genealogies were learned in metric patterns involving changes of pitch for each generation, similar to intonation of waiata, in formalised patterns designed to aide the memory...Genealogies were often rendered at a speed and in a tone of voice designed to protect both the tapu information and the status of the tohunga.

Although the emphasis on the oral retention of whakapapa has been maintained, the development of writing in Māori communities has meant that whakapapa and its associated knowledge have also been 
recorded in manuscripts and books. Strict protocols exist around the handling of such manuscripts.

The critical feature of whakapapa is that an individual's identity was primarily defined and given meaning through their relationships with others. The emphasis was on social connectedness. This was expressed in whakatauākī and pepeha (proverbs or sayings) and in waiata (songs) and pūrākau (historical narratives). These declarations not only consolidated relationships with ancestors and the natural environment, they also served to differentiate Māori on the basis of distinctive hapū and iwi.

Historically, as Taonui (2011) points out, whakapapa “...did not list all individuals, marriages and tribes, but focused on those that were important and relevant for the time." Indeed, whakapapa was crafted in different ways to suit different situations and contexts. Ngata, for example, identified a number of variations in the form that whakapapa could take: "taraere" involved the recitation of a single line of descent from an ancestor, without the inclusion of marriages or other kin; "whakamoe" traced descent from an ancestor and included the marriages and subsequent kin; "tahu" set out the main descent lines for an iwi or hapū; "whakapiri" were used to define a person's position in respect of another on the basis of their seniority in the descent line.

For this reason, whakapapa took on different forms for different audiences and purposes. As Te Rito $(2007,2)$ has observed:

The technique of tararere is particularly useful when dealing with the names of ancestors where little is known of spouses and other lateral links. As we come closer to modern times the techniques of whakamoe and of whakapiri become particularly useful, as the knowledge of lateral ancestors like spouses, is more to the forefront of people's memories. Their stories are better remembered and the 
narratives become easier to fill out. In other cases, for ease of presentation, the whakapapa can be displayed laterally rather than vertically. This method is suitable for example when there are multiple spouses.

Where only main or key ancestors are shown, the technique of tahu is suitable. This technique is also suitable in other cases, for example when some siblings may be more well- known than others for their deeds and may consequently have a high profile, while others may have died as babies on the other hand and consequently be lesser known. Furthermore, with large families it is often quite difficult to represent all its members within the confines of the written page as the whakapapa charts can easily become quite cluttered and cumbersome to manage.

Although whakapapa is commonly viewed as the most fundamental feature of being Māori today, it is clear that there is not necessarily a direct correspondence between whakapapa and identifying as "Māori" in contemporary New Zealand society. The New Zealand 1996 Census of Population and Dwellings is particularly revealing in this regard. Using separate questions, the census required respondents to identify the ethnic group(s) to which they belonged to as well as whether they were of Māori descent. Question 10 of the 1996 Census allowed respondents to select more than one ethnic group (of which, "NZ Māori" was one of a number of possible ethnic categories). In addition, Question 13 asked respondents whether they were, "...descended from a NZ Maori (that is, did you have a NZ Maori birth parent, grandparent, or great-grandparent, etc.)?"5 579,714 people, or 17.3 percent of the New Zealand population on census night, said they were of Māori descent. Of those people who said they were of Māori descent, 84.7 percent also identified with the Māori

\footnotetext{
${ }^{5}$ Statistics New Zealand (1998), 1996 New Zealand Census of Population and Dwellings: Iwi, Wellington: Statistics New Zealand.
} 
ethnic group. The fact that 15.3 percent of respondents claimed to be descended from a NZ Māori but did not identify as Māori in an ethnic sense, demonstrates that while whakapapa may be an essential requirement it is not necessarily sufficient by itself.

This trend was repeated at the last Census of Population and Dwellings in 2006, which also distinguished between those claiming Māori descent (who numbered 643,977 or 17.7 percent of the population usually living in New Zealand), and those actually identifying themselves as Māori $(565,329)$.

There are clearly a range of other factors which appear to influence an individual's decision to identify as Māori as opposed to simply declaring that one's ancestors were Māori. Anecdotally, an individual's cultural background, proficiency in the Māori language, the influence of popular ideas around 'race' (and perhaps the legacy of ideas about 'racial purity'), the strength of an individual's ties to iwi and hapū, and the intensity of ethnic attachments ${ }^{6}$ appear to be significant factors. In this way, even in situations where whakapapa is established, there may be intense debates over how to determine the depth or authenticity of an individual's identity. Was the individual raised within their tribal territory? Were they immersed within the tikanga of their hapū and/or iwi? Do they speak Māori? Claims to Māori identities based on these more essentialist, "traditional" markers tend to be given more weight in the broader discursive milieu.

\footnotetext{
${ }^{6}$ At the 2006 Census, 42.2 percent of Māori stated that they also identified with European ethnic groups, 7.0 percent with Pacific peoples ethnic groups, 1.5 percent with Asian ethnic groups, and 2.3 percent also gave 'New Zealander' as one of their ethnic groups.
} 
Rāwiri Taonui (2011) describes a number of new expressions that have evolved in the context of contemporary debates about Māori authenticity. For example, the phrase "born-again Māori" is employed pejoratively to describe those Māori who are usually of mixed descent and who may not have previously acknowledged their identity as Māori. There is sometimes an implicit assumption that those Māori have emerged at a time when the rewards and opportunities associated with being Māori were greater, but were conspicuously absent in the struggle against racism and prejudice, which came at a considerable personal cost to many individuals and families. The phrase also indicates a tension over the idea that Māori identities can be voluntary. In other words, the prevailing notions of authenticity are more hostile towards the idea that one can be Māori as matter of choice at a particular time and place, rather than being Māori in an inherent and involuntary sense.

A related term, "plastic Māori" (i.e. meaning ersatz and therefore inauthentic), is a term sometimes used by cultural nationalists to refer to those Māori who do not possess an understanding or proficiency in te reo Māori (Māori language), or a knowledge of tikanga (cultural protocols) and whakapapa (geneaology). These Māori are often viewed as "de-cultured" and "assimilated". They are frequently depicted as hapless victims of colonisation, intoxicated by the material trappings of 'Pākehā ${ }^{7}$ society' and alienated from their true identities.

In addition, the terms "waka blondes" and "kōtuku mā" (white herons) are used to describe Māori who possess what are considered "non-traditional" phenotypical features such as fair skin and/or hair colouring, and blue or green eyes. It is important to emphasise that these terms are not necessarily used in a pejorative sense within Māori

\footnotetext{
${ }^{7}$ Pākehā is the Māori language term used to refer to New Zealanders who are the descendants of British settlers.
} 
communities. Indeed, the validity or authenticity of these identities will more often than not rest on other cultural and social factors. Nevertheless, assumptions about the physical characteristics and traits associated with being Māori continue to shape social interactions in wider New Zealand society. Furthermore, those who are unable to project these identifiable biological traits and stereotypes, find other ways of activating and performing their Indigeneity in the course of interactions with others.

\section{The Idea of 'Race' and the Biological Categorisation of Māori}

The idea of "race" and the notion of blood quantum have profoundly shaped both historical and contemporary notions of Māori identity in Aotearoa/New Zealand. Official State policies with respect to Māori were strongly influenced by ideas about racial purity, social Darwinism, and the assimilative paradigms of New Zealand nationalism.

Racial policies were, however, applied inconsistently and often in a contradictory fashion. On the one hand, Māori were frequently represented as "noble savages," a term associated with a romanticised depiction of indigenous peoples as living a life of harmony uncorrupted by the excesses of Western industrial life. On the other hand, Māori were consistently represented as "racially inferior" to their European counterparts. These views were well rehearsed on a global scale. Indeed, the alienation of the lands and resources of indigenous peoples was justified as part of the "natural" evolutionary process. It demonstrated the inherent superiority of the colonising 'races' and the inferiority of the colonised.

A significant decline in the Mãori population by the later part of the nineteenth century seemed to lend credence to social Darwinist notions of the "survival of the fittest." The rapid influx of European 
migrants, recurrent epidemics, high infant mortality, and declining resources as a result of land alienation saw Māori “...relegated to a precarious existence on the fringe of a rapidly expanding Pakehadominated state" (Pearson 1990, 57). By the turn of the twentieth century, Māori-who had been the numerical majority in around 1860 --were a mere four percent of the total New Zealand population. In the colonial imagination, this was simply the inevitable consequence of a clash of superior and inferior "races."

The Māori population began to recover by the early twentieth century. Nevertheless, few disputed the inevitability of assimilation as a priority for state policy. For this reason, the children of Māori and Pākehā unions were often depicted in a more positive light. As well as the apparently more favourable aesthetic qualities associated with "halfcaste" children, they were also said to personify the "dilution" of a potent "Maori" essence that was resistant to assimilative pressures. In other words, being Māori was a contaminating factor that could be bred out of existence or, with an administrative sleight of hand, categorised out of existence. Those who were categorised as being less than "half" blood could be "salvaged" because their "white blood" was their springboard to successful assimilation.

For this reason, in addition to distinguishing "half-caste Māori" from "full-bloods," a further distinction was drawn between half-castes whose mode of living was Māori, and those who lived as European. ${ }^{8}$ After the 1921 census, the lifestyle distinction between MāoriEuropean half-castes was discarded and all half-castes were statistically assigned to the Mãori population. At the same time the concept of blood quantum was extended from half-caste to embody a

\footnotetext{
${ }^{8}$ See Kukutai, T.H. (2010), 'The Thin Brown Line: Re-Indigenizing Equality in Aotearoa New Zealand', Unpublished PhD Thesis, Stanford University
} 
wider range of racial designations including "three-quarter-caste" and "quarter-caste."

Of course, notions of "race" and "racial purity" were tied up with political rights and entitlements. Until the passing of the Māori Affairs Amendment Act in 1974, a Māori was defined as someone with "half or more blood". From 1896 up until 1967, Māori (except "half-castes") were not allowed to stand as candidates in European seats. Until 1975, only so-called "half-castes" were allowed to choose whether they voted in the General Electorates or the Mãori Electorates. In 1975 the Labour government introduced a "Māori electoral option", to be held alongside (or following) each census. This also allowed electors of Māori descent to choose whether they enrolled in general or Māori seats.

The idea that being "Māori" is principally a matter of blood quantum (and that, by extension, the essence of "Maori" identity is a discrete set of phenotypical characteristics) still influences many popular understandings of contemporary Māori identities. As Tūhoe scholar, Tracey McIntosh (2001) notes:

I have been asked many times why I self-identify as Maori, the underlying thrust of the inquiry being less posed as an inquiry of interest but rather offered as a challenge; that is, a questioning of the authenticity of my claim. My authenticity is questioned due to the simplest of things: colour. Being of fair complexion means that for many my persistence to identify as Maori is seen by some (nonMaori) as a form of romantic stubbornness while for others it is seen as merely perverse.

The notion that the "racial essence" of Māori has been increasingly eroded after two centuries of contact, and that there are now no "real" (that is, "racially pure") Māori left in New Zealand, has been firmly entrenched in the public's consciousness. This is, of course, a very 
convenient justification for ignoring indigenous grievances. If there are no "real Màori" then there is no need to confront the colonial atrocities of the past and the continued marginalisation of indigenous communities in the present.

In the context of the assimilative pressures of New Zealand nationalism, to claim a Māori identity when one should simply "pass" as Pākehā is often represented as an intentionally divisive act. With its direct appeal to national interest, the infamous catch cry, "we're all New Zealanders" has frequently been employed to deny legitimacy to Māori struggles for the return of land, a greater share of society's resources and an active role in formal decision-making processes. The mythology of "one people, one nation" has been the bedrock of the assimilative ideologies that have underpinned government policy with respect to Māori for well over a century.

\section{The Politicisation of Māori Ethnicity}

From the 1970s onwards, there was a gradual shift in the New Zealand based social science literature from an emphasis on "race" and biology to a concern with culture and "ethnicity." Although, blood quantum continued to be used as a way of measuring identities in the official New Zealand Census until 1981, the emphasis on ethnicity was part of a growing critique of the idea of "race" and the notion that biological racism (at least in its more explicit forms) was politically and morally disreputable. It led many social scientists to search for more positive, self-defined and empowering ideologies. This took place in the context of the politicisation of "ethnic" identities in response to racism and the legacy of colonialism. It was an integral part of a more generalised upsurge in struggle which included anti-colonial movements in the so called "third world," national liberation struggles against Western imperialism, the civil rights movement in the United States, the proliferation of a variety of social movements (anti-war 
movements, the women's liberation movement, environment movements, gay and lesbian rights movements, and so forth), and the struggles of indigenous peoples on a global scale.

Since the late 1960s, one of the critical features of the evolving ideology of Māori political activism was an emphasis on the positive aspects of being 'Māori' in an attempt to unite diverse Māori communities in struggle. The construction of a contemporary Māori ethnic identity has been a contested social and political process that has involved the selective reconstruction of symbols and beliefs from the past and their adaptation to the contemporary political environment (Poata-Smith 2001). This centrally involved the conscious employment of ideological constructs that replaced the more innocuous and apolitical term "Polynesian." Specifically, it involved using the language employed by black power movement in the United States. This generated an aggressive and assertive meaning to being Māori or "black." As an ideological construct, black implied a resistance to white values, social structures and institutions and represented an inherent commitment to alternative aesthetic standards (Greenland 1991, 98). It emphasised the inherent polarity of Māori and Pākehā world views.

This assertive concept of being Māori involved an individual reaction against the racist assumptions of New Zealand society which found expression even when it came to personal appearance: aesthetically, the way forward for individual Māori had often seemed to be straightening their hair and lightening their skins. This was rejected fundamentally with an unabashed expression of "Māoriness" through hairstyle, dress codes, behavior, and name changing to reflect more "authentic" Māori identities. Greenland $(1991,99)$ notes that such a challenge to the conventional and traditional categories of Māori identity propagated a sense of collective identity and solidarity in 
struggle which transformed the attributes of phenotype into "...an overt semiotic combat."

It is important to appreciate that this symbolic construction of a paniwi "ethnic solidarity" compensated for the absence of other more localised and regional identifications (particularly te reo Māori and tikanga), which had united preceding generations of Māori on the basis of iwi and hapū. Despite the perceived loss of traditional authenticity, the physical expression of ethnic solidarity performed the function of maintaining a distinctive "Māori identity" which differentiated itself culturally and politically from the bilingual Pacific migrants who had maintained a national homeland and cultural protocols the likes of which had not been passed on to the post-1950s Māori generation.

The development of the idea of a Māori community united in resistance by virtue of their common ethnicity drew on and influenced revisionist accounts of colonisation and Māori resistance that were emerging within academia (Sharp 1990, 4). Revisionist accounts of New Zealand history demonstrated the unique nature of Māori politics and made available accounts that depicted the exploitative nature of colonisation and the active role of Māori in response. ${ }^{9}$ These historical accounts established an interpretation of history incompatible with popular myths such as the view of colonialism as the "white man's burden" and of New Zealand as a "one people

9 For example see, T. Simpson, Te Riri Päkehä: The White Man's Anger, Auckland: Hodder and Stoughton, 1986. D. Scott, Ask that Mountain: the Story of Parihaka, Auckland: Reed/Southern Cross, 1981. A. Ward, A Show of Justice; J. Binney, et al. Mihaia; J. Belich, The New Zealand Wars; C. Orange, The Treaty of Waitangi; M.P.K Sorrenson, "Towards a Radical Reinterpretation of New Zealand History: the Role of the Waitangi Tribunal”, pp. 158-178; J. Kelsey, "Legal Imperialism and the Colonization of Aotearoa", pp. 20-43. 
nation." They debunked the view of the Treaty of Waitangi as a sacrament of harmonious ethnic relations and a symbol of peaceful coexistence. These revisionist narratives also gave powerful coherence to contemporary struggles for Māori autonomy by linking them to historical traditions of resistance in a way that transcended disparate iwi and hapū experiences of everyday life.

The tangible symbol that united past, present, and future generations of Māori was the land. Indeed, the historical fact of land alienation provided a rallying symbol and focus for protest providing a contemporary basis for pan-tribal unity. ${ }^{10}$ During the land rights movement of the 1970s, land alienation became the central political and historical feature that underpinned all others. Greenland (1991, 93-94) identifies three ideological themes that were developed in this regard. The first theme emphasised the inherent polarity between two allegedly conflicting approaches (Māori and Pākehā) to land: one emotive and communal, the other material and individualistic, one natural and environmental, the other artificial and exploitative. The gap between Māori and Pākehā conceptions of land was irredeemable and the political significance of this was crucial to the demands of the activists. The second dimension emphasised the notion of tāngata whenua (people of the land), “...the common origin and fundamental unity [of all Māori] based on an organic primordial connection with the land" (Greenland 1991, 94).

The third theme posited a link between a variety of contemporary social problems such as alcoholism, unemployment, lower life expectancy, psychological illness, high rates of imprisonment,

\footnotetext{
${ }^{10}$ See Poata-Smith, E.S. Te Ahu (1996) 'He Pōkeke Uenuku i Tu Ai: The Evolution of Contemporary Māori Protest', in Spoonley, P., Pearson, D. and Macpherson, C. (eds) Ngā Patai: Racism and Ethnic Relations in Aotearoa/New Zealand, Palmerston North: Dunmore Press.
} 
violence, and poverty to the historical fact of land alienation (ibid.). The fact of land alienation provided a concrete link between everyday political struggle and the all-embracing political attack on "Pākehā society."

The assumption that there is an 'essence' or set of innate and inherent characteristics that define Māori and Pākehā identity, which have remained constant throughout history, underpins Māori cultural nationalist political ideology and practice. For instance, Pākehā are said to embody inherent characteristics: they are competitive, exploitative, and value material success (Greenland 1991, 97). Māori communities on the other hand, are said to be co-operative and communal, reflecting the importance of the collective will of the people and their natural relationship with the environment.

The emphasis on the rediscovery of "culture" as a panacea to the issues confronting contemporary Māori communities continues to have a significant impact on arguments about the authenticity of Māori identities. The revitalisation of te reo Māori (the Māori language) is frequently at the heart of this process. The argument that the significance of Māori cultural paradigms can only be comprehended through immersion in Māori language, and by extension, that te reo Māori is a fundamental feature of authentic Māori identities, has been an influential narrative.

In this regard, researchers and public policymakers have sometimes uncritically accepted essentialist notions of authenticity. This is particularly the case for research that focuses on the measurement of Māori cultural identity or ethnic group attachment. For instance, the "Best Outcomes for Māori: Te Hoe Nuku Roa" project is a 25-year longitudinal study of Māori households run by the Research Centre for Māori Health and Development and Te Pūtahi-ā-Toi, the School 
of Māori Studies at Massey University. ${ }^{11}$ The study involves 700 Māori households and is based on the development of a "Māori relevant" framework to gauge personal and family development. ${ }^{12}$ The study proposes a measure of Māori identity which places the highest weighting on Māori language and is followed by "involvement in extended family," "knowledge of ancestry," and "self-identification." The fact that Māori language is weighted so heavily as an indicator of Māori identity is interesting given the lack of fluency that exists amongst contemporary Māori. Indeed, the National Māori Language Survery shows that, “....although 59\% of Māori adults speak the Māori language to some extent, the majority (83\%) have either low fluency or do not speak Māori at all. Most Māori adults said that they found English the easiest language to converse in. Only 8\% of Māori adults are highly fluent..."13

This is not to suggest that Māori language is not a valuable and important dimension in the lives of many Māori, nor that communities should not invest in its revitalisation. What it does reveal, however, is the influence of certain essentialist assumptions about the relationship between Māori language and claims of authenticity. Such weightings privilege the narratives of more powerful and influential members of Māori communities while

\footnotetext{
${ }^{11}$ See Forster, M. (2003). Te hoe nuku roa: A journey towards Māori centered research. Ethnobotany Research \& Applications, 1, 47-53; Cunningham, C., Stevenson, B., \& Tassell, N. (2005). Analysis of the charaterictics whānau in Aotearoa. Wellington: Massey University, Ministry of Education.

${ }^{12}$ See Best Outcomes for Māori: Te Hoe Nuku Roa http://www.tehoenukuroa.org.nz/about_us.htm

${ }^{13}$ Te Puni Kōkiri, Te Taura Whiri i te Reo Māori, and Statistics New Zealand (1998),Te Mahi Rangahau Reo Māori: The National Māori Language Survey, Wellington, p.10.
} 
disregarding or ignoring the lived experiences and views of other members.

\section{Iwi}

Some have responded to the evolution of a sense of Māori ethnicity by claiming that it represents an "invention of tradition" that is not a natural product of an essentially tribal people. ${ }^{14}$ The idea that authentic Māori identities are essentially iwi-based identities has been articulated by a number of prominent Māori leaders. Sometimes such an argument involves a suspicion about the State's historical encouragement of pan-tribalism and the cultural homogeneity that is implicit in the concept of "Māori ethnicity."

In one of the first collection of articles on Māori issues published by Māori authors in the mid-1970s, Tūhoe kaumātua (elder), John Rangihau (1992, 190) wrote of his:

faint suspicion that Maoritanga is a term coined by the Pakeha to bring the tribes together. Because if you cannot divide and rule, then for tribal people all you can do is unite them and rule. Because then they lose everything by losing their own tribal histories and traditions that give them their identity.

Rangihau (ibid.) famously described the centrality of iwi to any articulation of Māori identity:

My being Maori is absolutely dependent on my history as a Tuhoe person as against being a Maori person. It seems to me there is no such thing as Maoritanga because Maoritanga is an all-inclusive term which embraces all Maori. And there are so many different aspects

\footnotetext{
${ }^{14}$ See for example the comments made by Sir Tipene O'Regan, in H. Melbourne (ed), Māori Sovereignty: The Maori Perspective, Hodder Moa Beckett, 1995, pp. 153-165.
} 
about every tribal person. Each tribe has its own history. And it's not a history that can be shared among others. How can I share with the history of Ngati Porou, of Te Arawa, of Waikato? Because I am not of those people. I am a Tuhoe person and all I can share in is Tuhoe history.

An iwi based identity may also provide a powerful sense of legitimacy for those who are not ascribed a Māori identity by outsiders. For example, Kai Tahu leader, Tipene O'Regan, who is of both Irish and Māori descent, recalls getting caught up in an argument between a Ngāti Porou and Te Arawa colleague, and being told to:

butt out on the basis that I wasn't a Maori. I was nothing but a Pakeha with a whakapapa...I remember sitting there as if a flash of revelation had come upon me. I was thrilled. I said, 'You are absolutely right. I am not a Maori. I'm Ngai Tahu!' I knew, when I said that, that no one could define it except me and my kin group, my iwil" (Melbourne 1995, 156)

The contemporary emphasis on the iwi as the basic social and political organisational unit of Māori society is, in part, a product of the Treaty of Waitangi claims process to settle historical grievances and the continuing influence of hierarchical and static models of Māori social and political organisation that underlie popular accounts of the past (Poata-Smith 2004).

Since the 1990s, the state has increasingly recognised those iwi that have been restructured as corporate entities as the official representative structures of contemporary Māori society, and the appropriate bodies for managing the hundreds of millions of dollars worth of assets that would flow from compensation deals with the Crown. The growing number of references in state policy documents to tribal formations re-conceptualised in this way, has entrenched the idea that Māori rights under the Treaty of Waitangi (apart from those 
of equal citizenship) accrue exclusively to iwi who are guaranteed sole rights to the resources within their takiwà (territory). This systematic privileging of iwi as the principal beneficiaries of Treaty settlements has also been reinforced by the courts. ${ }^{15}$

Although it is widely acknowledged that the Treaty of Waitangi settlements should ultimately benefit all Māori, there is growing concern that Māori individuals and groups who (a) are uncertain of their iwi origins; (b) have weak associations with their iwi; (c) live outside their tribal takiwā (territory); or (d) choose to live and work in an urban environment, may encounter difficulty in directly participating in benefits distributed through iwi. In the context of the prolonged litigation brought against the Fisheries Commission by urban Māori authorities challenging the allocation of assets solely to iwi on the basis that they were the traditional "tribes," some have seen urban Māori as harbingers of destruction for "authentic" or "traditional" sources of Māori political authority (Robertson 1997, 5).

Nevertheless, iwi are not the permanent, timeless entities that are often presented in popular accounts of the past. Māori social and political relations were, in fact, far more dynamic and flexible than is generally conveyed. Unfortunately, many tribal histories have uncritically accepted, and sometimes perpetuated, ethnological accounts that were based on the notion that iwi were "contiguous principalities" or discrete kingdoms ruled over by "principal chiefs." To some extent, these developments reflect the influence of colonial administrative paradigms that attempted to codify the complexity and fluidity of Māori land tenure and social and political relations and

\footnotetext{
15 Treaty of Waitangi Fisheries Commission, Ahu Whakamua -Report for Agreement: A Report by the Treaty of Waitangi Fisheries Commission on the Allocation of Assets and Distribution of the Fisheries Settlement, Wellington: Treaty of Waitangi Fisheries Commission, August 2002, p. 26.
} 
translate it into a more simplified and truncated hierarchy of single "tribes" with politically subordinate sub-divisions. It also reflects the influence of the Native Land Court, as judges and assessors redefined features of the traditional Mãori social and political organisation and forced it to conform to a preconceived legal order based on capitalist private property and the ownership of discrete territories by iwi (Parsonson 1992, 190-194).

These notions were, of course, especially attractive to officials looking for an easily identifiable, all-embracing, and authoritative body with which to negotiate land purchases. The projection of this static and hierarchical paradigm into pre-colonial history, however, is fundamentally problematic. As Ward $(1993,202)$ emphasises:

the supposedly neat hierarchy of whanau, hapu, and iwi, with its rangatira and its ariki (a tidy pyramidal model which still gets trotted out in anthropology and sociology that feeds upon previous publication rather than undertaking original research or checking the most recent writings) was not actually like that.

Indeed, while ethnological reconstructions of pre-European Māori life certainly identify whānau, hapū and iwi as basic units of social organisation in pre-European Māori society (based as they were on kinship and particularly on descent from a common ancestor), Māori social and political relations were far more dynamic and flexible than is generally conveyed. First, iwi, hapū and whānau were not hermetically discrete social, cultural, and political entities inhabiting exclusively maintained bordered territories. Rather, they were complex constellations of lineages woven together by intermarriage, political alliance, and by migration and resettlement.

Because Māori descent groups were, and continue to be, ambilineal in nature-that is, they are based on descent through either male or female lines (or both), and because all of these genealogical links are 
retained - Māori have always been able to regard themselves as belonging to any number of potential descent groups (Mahuika 1992, 54). They could and frequently did "activate" their rights to the hapu and iwi of both parents by residing with different communities of which these descent groups were part at different times of their lives (Ballara 1991, 32). Furthermore, the ongoing process of intermarriage meant that many hapū did not necessarily regard themselves as belonging exclusively to one iwi: they had descent lines from several. There has always been the potential, therefore, for Māori to identify strongly with multiple hapū and iwi.

A hierarchical tribal system of government based on capitalist property rights was not only a useful device to simplify the acquisition of Māori land, it also served as a useful mechanism of social control as Māori resistance to land alienation gained momentum. It allowed the cultivation of indigenous "go betweens": tribal leaders co-opted within the machinery of the colonial state in order to maintain a maximum degree of political cohesion and prevent resisting hapū and iwi from undermining the emerging capitalist social relations of production. Furthermore, it proved, in the long term, a convenient political fiction because it provided a pragmatic solution to the many problems associated with developing a central administrative framework to control complex indigenous affairs. This model of Māori political organisation was eventually entrenched in legislation by successive governments who established statutory trust boards on tribal lines to facilitate dealings between central government and Māori (Ross 1998).

These static and hierarchical models formulated in the nineteenth century and perpetuated by both scholars and colonial officials have been challenged by those emphasising the role of the hapu as the effective, independent political unit of pre-European Māori society (Barnao 1998, 6). Certainly, in the eighteenth century, decision- 
making frequently took place at a much more localised level than the widely dispersed iwi that we are so familiar with today (Lian 1987, 454; Schwimmer 1968, 28-29). It is also clear that hapu remained the primary political, economic and social units of Māori society well into the twentieth century even after the general acceptance by Māori of iwi as an alternative representative body in some circumstances (Ballara 1991, 282).

The notion that only iwi are the appropriate entities to receive shares of the settlement proceeds (Levine 2001, 161) excludes those individuals and groups who can not trace their links to 'traditional iwi' or who seek comfort and solace in the urban context where they live. ${ }^{16}$ This represents a significant proportion of the Māori population. Indeed, at the 1996 Census, around the time of the debates over the allocation and distribution of the benefits of the fisheries settlement, 153,480 people of Māori descent (26 percent) either did not know the name of their iwi, or indicated they were affiliated to an iwi but did not give a response that Statistics New Zealand identified as a specific iwi. Breaking this down further, one in five Māori (19 percent) did not know the name of their iwi while a further 7 percent did not specify the iwi they belonged to. ${ }^{17}$

Rather than create institutional arrangements that actually relate to the contemporary reality of a considerable proportion of Māori society, the state has actively encouraged the re-tribalisation of Māori society. The Treaty of Waitangi Fisheries Commission, for instance,

\footnotetext{
${ }^{16}$ See Treaty of Waitangi Fisheries Commission, Ahu whakamua: The Treaty of Waitangi Fisheries Settlement: What it means for you-Summarising the Report for Agreement on the Allocation of Assets and Distribution of Benefits of the Treaty of Waitangi Fisheries Settlement, August 2002, p. 3.

${ }^{17}$ Statistics New Zealand (1999) Profile of Māori Descendants who did not know or did not specify an iwi, Wellington: Statistics New Zealand, p. 7.
} 
has set up a toll-free "iwi helpline" to assist those "de-tribalised" Māori to find their iwi. By 2006, a total of 102,366 people of Māori descent did not know their iwi. This represented a decrease of 9.1 percent since 1996. Nevertheless, these efforts to connect Māori with the appropriate iwi clearly entails a partisan view about the legitimacy of those Māori who identify themselves in hapū either in ethnic terms or as members of urban Māori communities. Through this process the state has effectively limited the way that Māori can express their identity in a contemporary context by categorising them into more convenient and allegedly authentic groupings. Failure to express contemporary Māori identity in these terms may ultimately damage the credibility of claimants involved in the Treaty settlement process.

\section{Conclusion}

One cannot understand the evolution of Mãori identities without acknowledging that they are an integral part of the web of social relationships that are themselves subject to change, redefinition and contestation. The negotiation and renegotiation of Māori identities involves claiming and resisting identities from within a set of prevailing discourses about the authenticity of particular indigenous categories. The social actors that articulate these discourses are themselves embedded in unequal sets of social, economic, and political relations.

The shifting nature of identity means that Māori individuals throughout the course of their lives can and do represent themselves differently depending on the particular time, space, and context. What we refer to as Māori identity therefore is principally a social process that expresses itself in the moving social boundaries and identities that indigenous people in Aotearoa/New Zealand, collectively and individually, draw around themselves in their relationships with others in the course of their everyday social lives. For this reason we 
cannot simply speak of Māori as a static group of people who share whakapapa (ancestry), culture, language, or other markers of difference. In order for Māori identity to be given meaning, the real or perceived differences of ancestry, culture and language need to be actually mobilised in everyday interactions with others. These dimensions, as Fenton $(1999,10)$ argues, are "...activated -or suppressed-in a wide variety of contexts."

While it is certainly the case that Māori individuals and groups have some degree of agency in the construction and maintenance of their collective and individual identities, people are, of course, not simply free to create or change their identities at will. Māori identities have been, and continue to be, negotiated and renegotiated in the context of the ongoing political, economic, and social subjugation of iwi, hapū, and urban Māori communities. They have also been constituted in the context of inequalities between Māori. As a result, particular narratives about what constitutes an "authentic" or "traditional" Māori identity have conflicting political implications for different groups of Māori in the present.

While the diversity of Māori lived experiences is more widely acknowledged than it once was, there is a tendency, nonetheless, to fall back on reified and simplistic notions of tradition, language, and culture as constituting an unchanging "authentic" essence of Māori identity. Rather than suggesting that those Māori who do not share all of these elements of culture are inauthentic or suffer from some degree of deprivation, it is important to acknowledge the diverse identities that result from the various experiences of being Māori in the many places in the world which Māori now live. This involves acknowledging the increasingly diverse circumstances in which Māori now find themselves. 


\section{References}

Calhoun, C. 'Social Theory and the Politics of Identity' In Social Theory and the Politics of Identity, edited by C. Calhoun, 9-36. Oxford: Blackwell Publishers, 1994.

Ballara, A. (1991), 'The Origins of Ngati Kahngunu', Unpublished Doctoral Dissertation, Victoria University of Wellington, 1991.

Barnao, P. 'Importance of Hapus [sic] stressed.' The Dominion, 27 May, 1998.

Brekhus, W.H. 'Trends in the Qualitative Study of Social Identities.' Sociology Compass 2, 3 (2008): 1063

Brewer, M. 'The Many Faces of Social Identity: Implications for Political Psychology.' Political Psychology, 22, 1 (2001): 115125.

Brubaker, R. and Cooper, F. 'Beyond 'Identity'. Theory and Society 29, 1 (2000): 1-47.

Calhoun, C. Critical Social Theory: Culture, History and the Challenge of Difference, Oxford: Blackwell, 1995.

Deaux, K. 'Social Identification.' In Social Psychology: Handbook of Basic Principles, edited by E.T. Higgins \& A. Kruglanski, 777798. NewYork: Guilford, 1996.

Eller, J.D. and Coughlan, R.M. (1993) 'The Poverty of Primordialism: The Demystification of Ethnic Attachments.' Ethnic and Racial Studies 16, 2 (1993).

Fenton, S. Ethnicity: Racism, Class and Culture. London: Macmillan Press, 1999.

Greenland, H. 'Māori Ethnicity as Ideology.' In Ngā Take: Ethnic Relations and Racism in Aotearoa/New Zealand, edited by P. Spoonley, D. Pearson, and C. Macpherson, Palmerston North: Dunmore Press, 1991.

Hall, S. 'Introduction: Who Needs Identity?' In Questions of Cultural 
Identity, edited by S. Hall and P. du Gay. London: Sage Publications, 1996.

Hogg, M.A., Terry, D.J. and White, K.M. 'A Tale of Two Theories: a Critical Comparison of Identity Theory with Social Identity Theory.' Social Psychology Quarterly, 58 (1995): 255-269. Jacobs, H. and Hirsh, B. Indigenous Land Tenure: Land Use in Alaska: Community Impacts of the Alaska Native Claims Settlement Act, Working Paper No. 16, North America Series, Land Tenure Center, University of Wisconsin -Madison, August 1998.

Levine, H. B. 'Can a Voluntary Organisation be a Treaty Partner? The Case of Te Whanau o Waipareira Trust.' Social Policy Journal of New Zealand 17 (2001): 161.

Lian, K.E.'Interpreting Māori History: A Case for a Historical Sociology.' The Journal of the Polynesian Society 96, 4 (1987).

Mahuika, A. 'Leadership: Inherited and Achieved.' In Te Ao Hurihuri: The World Moves On: Aspects of Māoritanga, edited by M. King. Auckland: Reed, 1992.

McIntosh, T. 'Contested Realities: Race, Gender and Public Policy in Aotearoa/New Zealand.' Paper prepared for the United Nations Research Institute for Social Development (UNRISD) Conference on Racism and Public Policy, Durban, South Africa, September 2001.

Melbourne, H. Maori Sovereignty: The Maori Perspective, Auckland: Hodder Moa Beckett, 1995.

Ngata, A. T. Rauru-nui-a-a-Toi lectures and Ngati Kahungunu origin. Wellington: Victoria University, 1972.

Parsonson, A. (1992) 'The Challenge to Mana Māori.' In The Oxford History of New Zealand 2nd ed.Edited by G.W. Rice, 190-194. Auckland: Oxford University Press,1992.

Pearson, D. A Dream Deferred: The Origins of Ethnic Conflict in New Zealand, Wellington: Allen and Unwin, 1990. 
Peterson, R.A. 'In Search of Authenticity.' Journal of Management Studies 42 (2005): 1083-98.

Poata-Smith, E.S. Te Ahu. 'He Pōkeke Uenuku i Tu Ai: The Evolution of Contemporary Māori Protest.' In Ngā Patai: Racism and Ethnic Relations in Aotearoa/New Zealand, edited by P. Spoonley, D. Pearson, D. and C. Macpherson. Palmerston North: Dunmore Press, 1996.

Poata-Smith, E.S. Te Ahu. 'The Political Economy of Māori Protest Politics,' Unpublished Doctoral Thesis, University of Otago, 2001.

Poata-Smith, E.S. Te Ahu. 'The Treaty of Waitangi Settlement Process and the Changing Contours of Māori Identity. 'In The Waitangi Tribunal, edited by J. Hayward, and N.R. Wheen. Wellington: Bridget Williams Books, 2004.

Rangihau, J. 'Being Māori.' In Te Ao Hurihuri: The World Moves On: Aspects of Māoritanga edited by M. King. Auckland: Reed, 1992.

Robertson, C. 'Urban Maori 'out to destroy society'.' The Evening Post, April 19, 1997.

Ross, M. 'Hard Lessons Still As Legal Basis Rests On Fiction.' National Business Review, 18 September, 1998.

Said, E. Orientalism: Western Conceptions of the Orient, London: Penguin Books, 1995.

Schwimmer, E. 'The Aspirations of Contemporary Maori.' In The Maori People in the Nineteen-Sixties: a Symposium edited by E. Schwimmer. Auckland: Longman Paul, 1968.

Sharp, A. Justice and the Māori: Māori Claims in New Zealand Political Argument in the 1980s. Auckland: Oxford University Press, 1990.

Taonui, R. 'Whakapapa - Genealogy - What is whakapapa?' Te Ara the Encyclopedia of New Zealand, 2011. Accessed at, http://www.TeAra.govt.nz/en/whakapapa-genealogy/1 
Taonui, R. 'Ngā tuakiri hou - new Māori identities - New terms for a new world.' Te Ara - the Encyclopedia of New Zealand, 2011. Accessed at http://www.TeAra.govt.nz/en/nga-tuakiri-hounew-maori-identities/5

Te Rito, J.S. 'Whakapapa: A framework for understanding identity.' MAI Review, 2 (2007): 2.

Ward, A. 'Historical claims under the Treaty of Waitangi.' Journal of Pacific History 28, 2 (1993): 202.

William, H.A. Dictionary of the Māori Language $7^{\text {th }}$ ed. Wellington: GP Publications, 1992.

Williams, J.P. 'Authentic Identities: Straightedge Subculture, Music, and the Internet.' Journal of Contemporary Ethnography 35 (2006): 173-200. 


\section{ON THE TEMPORALITY OF INDIGENOUS IDENTITY}

\section{Lewis R. Gordon}

There is a tendency in readings of indigenous identity to impose notions of authenticity that place indigenous people out of time. The presumption is that time is so conditioned by modern life, that to articulate a genuine indigenous identity requires resistance not only to such time but also to time narratives. The contradiction, however, is that the very problematic of raising Indigeneity is a function of that temporal imposition. Thus, in effect, the narrative of authentic Indigeneity is a very much modern one. Writing on the U.S. context, Kevin Bruyneel puts it this way: "The point here is that the words Indian and American Indian, like Native American, aboriginal, and indigenous, emerged as a product of a co-constitutive relationship with terms such as colonisers, settler, and American" (2007, ix). It does not follow, however, that the problem must be posed in a Manichean all-or-nothing manner. That indigenous people of today are very much of the present means that the negotiation of imposed and resistance culture produces a mixture that could be called the intersubjective constitution of contemporary culture. In other words, there is the lived problematic of producing living culture. That means that the indigenous today, albeit connected to ancestral forms of knowledge and cultural formation, are also the transformation of those norms in the ongoing human production of culture. This argument leads to a criticism, then, of the construction of indigenous people as, in effect, haunting the present.

These problems are similar to those of Jews in the West. Many models of modernity were premised on the emergence of Christianity. 
Although both Christianity and Rabbinic Judaism emerged through the historic mixture of ancient Judea and the Roman Empire, the transformation of the latter into the Holy Roman Empire led to the death of Rabbinic Judaism as a proselytising religion. ${ }^{3}$ Ironically, combining the narrative of continuation in terms of pre-Roman times with the mixture of Roman laws and Judean laws (halacha) led to a narrative of Christianity pointing to the future with the expectation of Judaism being locked into the past. Judaism, went through its own transformations, as did Christianity: denominations of both emerged in a new form of modernity, namely the one governed, at least in epistemological terms, by natural science. The result is the continued presence of a Judean framework, now known as Jewish, in spite of a general demographic of two percent in Europe and North America and even less than that in many parts of the world, save the country of Israel (Fishbane 1987). Yet, though there are Jewish people in contemporary political life, there is a sense in which Israelites, the people on whom Judaism is based, may well be figments of the past (Gordon \& Gordon 2009).

This narrative thus poses three problematics. The first is about the identity of a people. We could look at it as an ontological matter of their "being," but it is also about their meaning. In other words, what they are is linked also to what it means to be whoever or whatever they are or supposed to be. It is a problem of anthropology - the extent to which it is a discussion of human beings, which implicates them in the complex logic (or anti-logic) of what it means to be human, especially where being human is challenged. The second problematic is about a

\footnotetext{
${ }^{3}$ On this history, see, e.g., Shaye J. D. Cohen, The Beginnings of Jewishness: Boundaries, Varieties, Uncertainties (Berkley: University of California Press, 1999) and Lewis R. Gordon, "Réflexions sur la question afro-juive," Plurielles: Revue culturelle et politique pour un judaïsme Humaniste et Lä̈que No 16 (2011): 75-82.
} 
fundamental predicament of the modern world. The modern West is wrought with narratives of freedom and emancipation wherein most Europeans seem to regard themselves as being unshackled from a stultifying past. ${ }^{4}$ Although not always explicit, the historical narrative of Columbus's inaugurating modern colonialist expansion marked for that world - a liberation from a period of domination in which, as they saw it, things were being set right in the form of a Reconquest. ${ }^{4}$ The Mediterranean having been dominated by Afro-Muslims in the west and a variety of so-called Oriental Muslims to the east, the new path of the Atlantic Ocean signaled a conception of Christianity and indeed, Christendom, of moving forward with Islam and Judaism, both once forms of modernity, now being condemned to the past. ${ }^{5}$ As Christendom made its transition into "Europe," this notion of being locked into prior times extended also to people outside of the framework of Christianity. Thus, the eventual conception of freedom emerged in which the emancipation of Christendom, marked by its transformation into Europe, was accompanied by rigorous

\footnotetext{
${ }^{4}$ I am writing here on the logic of modernity. For an outline of various positions on this question, see Lewis R. Gordon, An Introduction to Africana Philosophy (Cambridge: Cambridge University Press, 2008), introduction and first chapter, and Walter D. Mignolo, The Darker Side of Western Modernity (Durham: Duke University Press, 2012).

${ }^{4}$ See, e.g., Rereading the Black Legend: The Discourses of Religious and Racial Difference in the Renaissance Empires, eds. Margaret R. Greer, Walter D. Mignolo, and Maureen Quilligan (Chicago: University of Chicago Press, 2007); Henri Pirenne, Mohammed and Charlemagne, trans. Bernard Miall (New York: Barnes and Noble, 1956); Ivan Van Sertima (ed.), Golden Age of the Moor, ed. Ivan Van Sertima (New Brunswick, NJ: Transaction Publishers, 1992); and cf. also Niccolò Machiavelli, The Prince, trans. Peter Bondanella (Oxford: Oxford University Press, 2005), chapter 21, p. 76.

${ }^{5}$ See Mignolo et al, Rereading the Black Legend, and Gordon and Gordon, Of Divine Warning, op. cit. See also Cedric Robinson, An Anthropology of Marxism (Aldershot: Ashgate, 2001).
} 
implements of servitude on those who belonged, supposedly, to the past. The third problematic is already hinted at in the first two namely, how to account for all of this? The movement from Christian man to "man" and from Christendom to "Europe", offered with it the presumption of moving away from the presupposition of emancipation through deed and knowledge, and as the latter increased, so presumably did the former. But how, if this were so, could it be justified? This last question demands, for the rest of our discussion, engagement with the first and the third problematics. In addition, they are germane to the task of this volume, as thinking about indigenous identity demands accounting for what it means and its justification.

\section{Problem of Indigenous Identity}

So we begin with the meaning of indigenous identity. However, in this instance, meaning is not merely lexicographic - a concern that could easily be addressed with a dictionary. What we are concerned with here are the circumstances faced by a human being whose relation to other human beings is mediated by being "indigenous." To be such is already a transformed condition, for there is no reason for any group of people to think of themselves in such terms except where another group of human beings have attempted to or have displaced them. If the other group was to remain in its identity as guests, where the norms of belonging stay as they were prior to the new group's arrival, then no contestation of first and last would emerge. There would simply be people doing what many people have always done: host guests. A peculiar development in the modern world, however, is the emergence of guests who transform themselves into settlers -guests who not only stay, but also assert a right to the future of the land. In effect, such guests affect belonging by rendering the hosts homeless, paradoxically, in their home. 
In the course of such displacement, a peculiar logic of what Frantz Fanon (1967) called "zombification of culture" emerges, where the lived and living reality of indigenous people collapses into the contradictory reality of the living dead. ${ }^{6}$ A human and living existence, Fanon argued, is one of open-endedness, of being a genuine interrogative or questioning possibility. To be such is to live in the interrelations of intersubjective life. He built this case for the human being as possibility in Peau noire, masques blancs (1952), translated as Black Skin, White Masks, through a series of provocative reflections of colonised and racialised subjects' investments in systems of modern assimilation. For such subjects, the modern world poses a set of values by which they can supposedly live by virtue of participation. The problem, however, is that each effort is marked by the contradiction of presumed failure. Mastering the imposed language supposedly promises assimilation, for example, but the reality of the language expressed in a coloured body receives social condemnation as contradictory. Linguistic imposition also demands the elimination of the coloured body, which is unsurpassable. The realisation of the social dynamics of meaning - what Fanon calls sociogenesis - leads to the disintegration of the identity myth of self-sustained substance or, prosaically, the modern individual. ${ }^{7}$ This failure emerges because the

\footnotetext{
${ }^{6}$ Cf. also Jane Anna Gordon and Lewis R. Gordon, Of Divine Warning: Reading Disaster in the Modern Age (Boulder, CO: Paradigm Publishers, 2009), chapter 5, "Ruin," pp. 103-116.

${ }^{7}$ For discussion of Fanonian sociogenesis, see, e.g., Sylvia Wynter, "Towards the Sociogenic Principle: Fanon, Identity, the Puzzle of Conscious Experience and What It Is Like to Be 'Black,'” in Mercedes F. Durán-Cogan and Antonio GómezMonaria (eds.), Natural Identities and Sociopolitical Changes in Latin America (New York: Routledge, 2001), pp. 30-66, and Lewis R. Gordon, "Is the Human a Teleological Suspension of Man?: A Phenomenological Exploration of Sylvia Wynter's Fanonian and Biodicean Reflections," in B. Anthony Bogues (ed.), After Man, Towards the Human: Critical Essays on the Thought of Sylvia Wynter (Kingston, JA: Ian Randle, 2006), pp. 237-257.
} 
individual is such in relation to other individuals, who, in turn, are such in relation to the world by which they are individuated - in other words, a social world. The problem, however, is that the social world in this case is saturated with colonising and historically racialised epidermal schema. Thus, efforts to escape it through individual will in acts of linguistic mastery, narcissistic love (being loved, and therefore seen, as not coloured, or more usually, white), dream and fantasy, humor, and valorised self-identity, fail. They do so because they commit the error of making the individual the problem instead of addressing the social system in which she or he lives.

Fanon makes many observations in his analysis of the construction of false imagoes and social rationalisations of oppression. One of them is about the pressures to offer the white world an image of the black self that is also alienating to the black. It is a portrait of what W.E.B. Du Bois calls the first stage of double consciousness, where one is pressured to see and present oneself as a dehumanised object. ${ }^{8}$ In the world of antiblack racism, that is the "negro" of the Americas or "nigger," which was used throughout the European colonies, including Australia. This dehumanised object, in which all the negative features of Western civilization are invested, is always someone else (as indicated by many blacks who refer to other blacks as "niggers") even, paradoxically, when it is self-referential, where a

\footnotetext{
${ }^{8}$ W. E. B. Du Bois, The Conservation of the Races (Washington, DC: The American Negro Academy, 1898); The Souls of Black Folk (Chicago: A. C. McClurg \& Co., 1903); Dusk of Dawn: An Essay Toward an Autobiography of a Race Concept (New York: Harcourt, Brace \& Co., 1940); and John Brown (Philadelphia: G. W. Jacobs \& Co., 1909). For discussion, see Lewis R. Gordon, Existentia Africana: Understanding Africana Existential Thought (New York: Routledge, 2000), chapter 4, "What Does It Mean To Be a Problem?," pp. 62-95, and Paget Henry, "Africana Phenomenology: Its Philosophical Implications," The C. L. R. James Journal 11, no. 1 (2005): 79-112.
} 
schizophrenic separation of ego and body emerges, in which the "nigger body" is there identified by a self from a here that is, in the end, nowhere. This imposition has, over time, become an expectation of so-called authentic blackness. Thus, Fanon observed he found himself in various interactions with the white world, "secreting blackness": "A man was expected to behave like a man," Fanon declared, but "I was expected to behave like a black man - or at least like a nigger" $(1952,114)$. And further on, "Little by little, putting out pseudopodia here and there, I secreted a race" (Fanon 1952, 122). ${ }^{9}$ The secretion of blackness is an infected social field; it is the layering over of human relations with projections, stereotypes, and arrays of expectations, the effect of which is epistemic closure: to see blackness is to know all one needs to know (Gordon 1995).

There is a form of secreting indigineity imposed upon indigenous peoples that is also embraced by those whose relationship to it is a form of first-stage double consciousness. This is where the indigenous person invests in the imposed identity and participates in the social field spread by presuppositions of authentic indigenous identity as an espistemically closed phenomenon. Secreting indigeneity leads to familiar presuppositions of contradiction, where being indigenous and modern are treated as oxymoronic: to be indigenous becomes wrought with mechanisms of pathology. For instance, Fanon argued that all human beings face maturation. Racism, however, bars maturity from whole groups of people, entrapping them in the logic of childhood. This leads to doubled abnormality: to be a black adult is to be abnormal; to be a black adult who acts like a child is to be an

\footnotetext{
${ }^{9}$ Cf. also, Kelly Oliver, The Colonization of Psychic Space: A Psychoanalytical Social Theory of Oppression (Minneapolis, MN: University of Minnesota Press, 2004 and Lewis R. Gordon, "When I Was There, It Was Not: On Secretions Once Lost in the Night," Performance Research 2, no. 3 (September 2007): 8-15.
} 
"authentic black," which, again, is an abnormal adult. The logic of childlike behavior is also temporal, it makes the subjects always situated behind the times, always, as Fanon observed, arriving too late. $^{10}$

The temporality of indigenous identity has, however, a more insidious form born from the logic of conquest and land (Gordon 2000, 153163). A feature of modern conquest, as we have seen, is the presupposition of empty or peopleless land, a principle known as terra nullius. ${ }^{11}$ To achieve a social world based on this premise required extraordinary acts of deception and self-deception. One approach was to annihilate the people, and although that tactic was often taken, it required admitting that there were people there in the first place hardly supporting the principle of terra nullius. (Thurton 1990) ${ }^{12}$ For those remaining people, and for others in cases where murder was not an option, the response was, through a complex network of pseudoscientific and legalistic rationalisations, to render them, in effect, peopleless bodies. In such instances, indigenous and First peoples were rationalised as the source of intrinsic illegitimacy. In cases of enslavement, the tendency was to argue for them having childlike qualities at best suitable for physical labor. In others, where the desire

\footnotetext{
${ }^{10}$ See Black Skin, White Masks, and Gordon, "When I Was There, It was Not," and "Through the Zone of Nonbeing: A Reading of Black Skin, White Masks in Celebration of Fanon's Eightieth Birthday," The C.L.R. James Journal 11, no. 1 (Summer 2005): 1-43. [Reprinted in: World \& Knowledges Otherwise: A Web Dossier, special issue: Post-continental Philosophy, edited by Nelson MaldonadoTorres 1, dossier 3 (Fall 2006):

http://www.jhfc.duke.edu/wko/dossiers/1.3/LGordon.pdf.

${ }^{11}$ For discussion, see Martin Nakata, Disciplining the Savages, Savaging the Disciplines (Canberra, Ausgtralia: Aboriginal Studies Press, 2007), p. 143; Carole Pateman, Carol Pateman, “The Settler Contract," in Carole Pateman and Charles Mills, Contract and Domination (Cambridge, UK: Polity, 2007), pp. 35-78.

${ }^{12}$ see also Bruyneel, The Third Space of Sovereignty.
} 
was for their land, arguments were unleashed against their capacity to generate laws and thus function as sovereigns. Denied the basis of justification or right, they became people "without rights," and thus found themselves attempting their defense according to impossible criteria; they had to be other than who they were: they had to be Christian or European, and, hence, white. A paradigm instance of this was The Cherokee Nation v. Georgia (1831) in the United States. That case sanctioned the removal of the Cherokee people from their lands in Georgia and the Carolinas. The decision argued that the indigenous peoples of North America were "wards" in a "state of pupilage" under their supposed "guardian," the United States. Justice Marshall, the judge with the majority opinion in the case, rejected the Cherokees' claim to being a foreign state, a sovereign. ${ }^{13}$ In her critical discussion of these events, Carole Pateman (2007, 35-78) points out that Australia, Canada, and the United States, three modern countries established upon settler agreements leading to cases such as Cherokee v. Georgia, all ultimately appealed to the falsehood of terra nullius as the grounds of their legitimacy. Premised on covenantal or social contract theories of original formation, what we could call a "settlers' contract," they each lay claim to having been founded on an original moment of social purity, a supposedly "clean slate."

Worsening matters, Australia, Canada, and the United States claim to be democratic nations, and to be expressions of the will of the people under their jurisdiction. How could this be supported, however, when there are people under their domain whose will was never respected by virtue of the historic rejection of their humanity? The dominating national narrative of the indigenous populations contends that they did not object to their conquest and colonisation because they could not have. This is because a supposed condition of objection is

\footnotetext{
${ }^{13}$ For more discussion, see Bruyneel, The Third Space, chapter 2, pp. 27-64.
} 
"civilized speech," a property such people supposedly lack. Their protests throughout the periods of their conquest, colonisation, and historical disappearance collapsed into hauntings, ghostlike echoes of what is sensed or inferred but absent, the way one experiences prior inhabitants of an empty but furnished house, especially one that has become a museum. That the indigenous and First peoples resisted throughout, leads to an important reformulation of, for example, Gayatri Spivak's famous essay on speech and subalternality, "Can the Subaltern Speak?" (1988). In reality, the question should be, "Could the Subaltern Be Heard?" (Gordon \& Gordon 2009) This question transforms the metaphor of hearing also into that of sight and touch, for they all come together in the question of a movement from appearance to disappearance and then to reappearance.

The expectations of secreted indigeneity undermines reappearance, since to appear in the logic that was part of the original disappearance carries with it the temporality of nonbeing in the future. This is because the political situation is, for the most part, unbearable to those whose legitimacy is a function of settlement society; their legitimate present and future makes the only temporal home for indigenous and First peoples properly the past. ${ }^{14}$

\section{Violent Reapparance?}

Indigenous and First peoples do not only face national fantasies of people locked in the past but also face exoticised narratives where the seduced include them as well. The modern world was not founded, after all, on a single narrative. There were also protests from within Christendom and Europe, and as high modernity led to moments of what Marxists call primitive accumulation and subsequent cycles of

\footnotetext{
${ }^{14}$ See Bruyneel, The Third Space of Sovereignty and Nakata, Disciplining the Savages, Savaging the Disciplines.
} 
crisis, the misery unleashed led to longings for better days organised through the mythopoetics of Judeo-Christian lore, at first, and then eventual fantasies of "perfect people," those among or without who "got it right." 15 "It," of course, is whatever project a given society is trying to achieve. Here, whether they be "Jews," "Christians," "Muslims," "peasants," "capitalists," "proletariats," and then back again: "pagans," "lost tribes," or just "tribes," such people are presumed out there, waiting for their historic moment to set humanity right. Here we find the extreme other side of the construction of problem people in the modern world - namely, the notion of intrinsically "unproblematic people." 16 The problem, however, is that in either direction, both extremes are, in effect, people who are other than human beings. In one direction, there is perpetual guilt, and in another, absolute innocence. Since children tend to be the models of

${ }^{15}$ For Christian protest at the dawn of modernity, see, e.g., Bartolomé de Las Casas, In Defense of the Indians, trans. Stafford Poole, C.M., foreword by Martin E. Marty (Dekalb, IL: Northern

Illinois University Press, 1992) and Enrique Dussel, “Anti-Cartesian Meditations: On the Origin of the Philosophical Anti-Discourse of Modernity," trans. George Ciccariello-Maher, article \#412 (2008): http://enriquedussel.com/philosophy.html, and Cedric Robinson, A Philosophical Anthropology of Marxism. Standpoint epistemology and politics tend to be at work with regard to the search for perfect people, but for a critical, nuanced view, see Walter D. Mignolo, Local Histories/Global Designs: Coloniality, Subaltern Knowledges, and Border Thinking (Princeton, N.J.: Princeton University Press, 2000) and Boaventura de Sousa Santos (ed.), Another Knowledge is Possible: Beyond Northern Epistemologies (London, UK: Verso, 2008). Cf. also, Lewis R. Gordon, "Esquisse d'une critique monstrueuse de la raison postcoloniale," trans. Sonya Dayan-Hezbrun, Tumultes, numéro 37 (October 2011): 165-183.

${ }^{16}$ On this matter, cf. Lewis R. Gordon, Bad Faith and Antiblack Racism (Atlantic Highlands, NJ: Humanities International Press, 1995), chapter 16, "Exoticism: Antiblackness Under the Guise of Love," pp. 117-123 and Michel-Rolph Trouillot, Global Transformations: Anthropology and the Modern World (New York: Palgrave Macmillan, 2003). 
the latter and the demonic that of the former, such routes are welcoming, perhaps, only to the perverse.

The demonic route offers the structural trap of illicit appearance. The exotic one, in effect, that of being angels, promises rude awakenings when attempted as practice. When one expects angels and gods and ends up meeting human beings, disappointment could easily collapse into rage - specifically narcissistic rage - since, in the end, imagining people in such terms could only be projection. Where that is the case, as Sara Ahmed (2004) among others have shown, it is the logic of narcissism at work. In fact, as Fanon $(1967,179)$ has also shown, the demonic is also a narcissistic performance but in the form of a projected threat through which the ideal self is able to shine. With the dark demonic exemplars on one hand, and the angelic ones on the other, they are two sides of the same desire for the ideal national self. That such a self receives much investment means it will not crumble lightly, and as it defends itself, it, in effect, regards itself victimised by efforts of disintegration, and it is unlikely that neither the present nor the future would be welcome temporal considerations for those whom they regard as the source of such a threat.

So, we come to an important challenge of any group facing structural dehumanisation. One strain of logic claims this to be a situation of being The Other. Such a position doesn't hold, however, since to be The Other, one must at least be a human being, and although one may be a human being in reality, it doesn't follow that one is perceived as such, especially by those controlling the conditions of legal appearance. As Fanon states, “Though Sartre's speculations on the existence of The Other may be correct...their application to a black consciousness proves fallacious. That is because the white man is not only The Other but also the master, whether real or imaginary" (1967, 138). Making this matter worse is one of two conditions of right. 
Recall those premised on settler society assert the supposed rightness of their society and their place in it. For those under the heels of settler society, their right place suffered displacement and they are left with the options of either maintained injustice or the search for justice in a reconstituted future. There is no reconciliation of these two conceptions of concrete justice. ${ }^{17}$ One conception depends on the maintained inequality of indigenous and First peoples as indigenous and First peoples, for if they were to abandon that status, to become bodies that no longer signify indigeneity or firstness, there is the avowed promise of full membership. ${ }^{18}$ The indigenous and First peoples then face the question of complicity in their continued social and political inequality or the transformation of that relationship through changing the social world of maintained inequality. ${ }^{19}$ That, however, would mean to appear where they were supposedly not to appear. Put differently, that would mean violating the sphere of appearance, to be, in effect, "violent."

This violence is, however, one of equality, and thus there is a paradox here. The modern world, after all, has offered equality as one of its

\footnotetext{
${ }^{17}$ See Frantz Fanon, Les damnés de la terre, préface de Jean-Paul Sartre (Paris: François Maspero éditeur S.A.R.L./ Paris: Éditions Gallimard, 1991; originally 1961), in English as The Wretched of the Earth, trans. Constance Farrington, with a preface by Jean-Paul Sartre (New York: Grove Press, 1963), and for discussion see Lewis R. Gordon, Fanon and the Crisis of European Man, chapter 4, pp. 67-84, and cf. also Lewis R. Gordon, "Phenomenology of Biko's Black Consciousness," in Amanda Alexander, Nigel Gibson, and Andile Mngxitama (eds.), Biko Lives!: Contestations and Conversations (New York: Palgrave, 2008), pp. 83-93.

${ }^{18}$ I will leave aside here the question of whether this could actually be achieved since the formulation already has the problem of, in effect, making such people's appearance problematic.

${ }^{19}$ For more discussion through a concrete example of this problem--namely, its unfolding in U.S. Native American politics-see Bruyneel, The Third Space of Sovereignty, especially chapters 5 and 6, pp. 123-216.
} 
values. The problem is that it is paradoxically an unequal equality. Equalising equality requires the transformation of social location, which means changing the relations by which human beings are ordered in a society. It means going through the decolonisation of the social world, which is, basically, to go through the painful process of radical change. Is this possible?

\section{Some Concluding Considerations}

One of the ways by which indigenous and First peoples are made into ghosts is through a failure to see them as agents of contemporary society and the modern world. There is no instance of such people in any quarter of the world without any contact with modern economies and ways of life - unless one continues to subscribe to notions of "lost tribes." One could imagine the scene: cutting through the bush, finding a remote area of the outback, or perhaps climbing slippery peaks, to discover a group of dazed people, perhaps sitting round a fire. "Who are you?" asks our explorer. "Don't know," the people respond. "We're lost...."

The search for people who got it right, for people of innocence, is also a search for purity (Monohan 2011; Gordon 2013). Supposedly unadulterated by the present, they remain "noble" and "pure." ${ }^{20}$ Anxieties and fears of impurity have often taken the form of a battle against mixture. We are familiar with attacks on biological mixture, but fear of the hybrid, the mixed, takes other forms as well. By making sure certain people stay in the past and cannot inhabit the future enables the logic of unadulteration. The problem, however, is that

\footnotetext{
${ }^{20}$ See Trouillot, Global Transformations, chapter 1, "Anthropology and the Savage Slot: The Poetics and Politics of Otherness," pp. 7-28; for critical discussion, cf. also Jane Anna Gordon, Creolizing Political Theory: Reading Rousseau through
} Fanon (New York: Fordham University Press, forthcoming 2012). 
human beings are always in relation to each other, which means that acts of separation are often done through the performative contradiction of connections; every effort to force purity requires contact, which establishes not only mixture (contamination) but also new sets of relations that change those who attempted to prevent them. Put differently, mixtures occur at every level of cultural life, even in the logic of its absence. More radical forms of mixture result in creolisation, where what actually lives in the present and reaches to the future are not supposedly authentically separate purities but something that transcends them. ${ }^{21}$ The logic of purity imposes on this creolisation a normative purity that makes the lived reality of such societies one of constant self-disavowal. At the biological and cultural level, indigenous and First peoples are aware of this - the extent to which nearly all live a doubled existence today of genetic ancestry both local and abroad, and cultural ancestry from levels of language and names of similar kind to the basic movement of the body in time. ${ }^{22}$ Think today of how strange it is to see the way people once moved as we see motion pictures from the past, whether directed or simply documented. The clue this story suggests is one of no small relation being changed without adjustments, and that if these are sufficiently accelerated, they could be the equivalent of a cultural chain reaction.

If I am correct that all human beings are ultimately part of the present condition of our species, then these changes must follow the logic of technological, geographical, and temporal compression that are

\footnotetext{
${ }^{21}$ See Monahan, The Creolizing Subject, chapter 6, "The Politics of Purity: Colonialism, Reason, and Modernity," pp. 136-182, and Jane Anna Gordon, Creolizing Political Theory, chapter 5, "Thinking Through Creolization."

${ }^{22}$ Cf. Bruyneel, The Third Space of Sovereignty, chapter 6, "Indigenous Sovereignty versus Colonial Time at the Turn of the Twenty-First Century," pp. 171-216, and Nakata, Disciplining the Savages, Savaging the Disciplines, chapter 7, "Disciplining and Regulating the Body," pp. 129-154.
} 
features of twenty-first-century life. Everything, in other words, is moving faster and everywhere is getting closer. We could call this the compression of time and space, or to be more culturally specific temporality and geographical reach. The result is a world that is getting smaller as our species gets numerically larger - 7 billion to date. Having so many human beings on a decreasing terrain means that human relations are now living through a radical upheaval that is nothing short of radical. ${ }^{23}$ What this means is that everyone must change to adapt to a world whose geophysical and environmental conditions will not obey the logic by which our various identities were formed. In other words, we are facing a transformation of the human being as each of us has understood ourselves to be, where only our formal capacity to question our condition as a closed one may be what is left, as we discover how much is no longer sustainable as we face the unknown. For indigenous and First peoples, then, the question of what it means to face the next epoch becomes one of challenging the categories that governed living in the current one. There is, then, indeed much to be done.

\footnotetext{
${ }^{23}$ For some considerations on these changes, see Bruyneel, The Third Space of Sovereignty, "Conclusion: The Third Space of Sovereignty," pp. 217-230; Nakata, ibid; Nalini Persram (ed.), Postcolonialism and Political Theory (Lanham, MD: Lexington Books, 2007); Boaventura de Sosa, "Globalizations," Theory Culture Society 23, nos. 2 and 3 (2006): 393-399; Lewis R. Gordon, "Labor, Migration, and Race: Toward a Secular Model of Citizenship," Journal of Contemporary Thought 32 (Winter 2010): 157-165; Walter D. Mignolo, The Darker Side of the Renaissance, "Afterword: 'Freedom to Choose and the "Decolonial Option / Notes toward Communal Futures," pp. 295-336; and "On How We Mistook the Map for the Territory, and Re-Imprisoned Ourselves in Our Unbearable Wrongness of Being, of Désêtre: Black Studies toward the Human Project," in Lewis R. Gordon and Jane Anna Gordon (eds.), Not Only the Master's Tools: African-American Studies in Theory and Practice (Boulder, CO: Paradigm Publishers, 2006), pp. 85106.
} 


\section{References}

Ahmed, S. The Cultural Politics of Emotion. New York: Routledge, 2004.

Bruyneel, K. The Third Space of Sovereignty: The Postcolonial Politics of U.S.-Indigenous Relations. Minneapolis: University of Minnesota Press, 2007.

Fanon, F. Black Skin, White Masks. Translated by Charles Lam Markmann. New York: Grove Press, 1967.

Fanon, F. 'Racism and Culture.' In Toward the African Revolution, edited by Josèphe Fanon, translated by Haakon M. Chevalier, 29-44. New York: Grove, 1967.

Fishbane, M. Judaism. San Francisco: HarperSanFrancisco, 1987.

Gordon, J. Creolizing Political Theory: Reading Rousseau through Fanon. New York: Fordham University Press, 2013.

Gordon, L. Fanon and the Crisis of European Man: An Essay on Philosophy and the Human Sciences. New York: Routledge, 1995.

Gordon L. R. 'Existential Borders of Anonymity and Superfluous Invisibility.' Existentia Africana. Understanding Africana Existential Thought. N.Y. L: Routledge, 2000. pp. 153-163.

Gordon, J and L. Gordon. Of Divine Warning: Reading Disaster in the Modern Age. Boulder: Paradigm Publishers, 2009.

Monahan, M. The Creolizing Subject: Race, Reason, and the Politics of Purity. New York: Fordham University Press, 2011.

Pateman, C. 'The Settler Contract,' in Carole Pateman and Charles Mills, Contract and Domination, Cambridge, UK: Polity, 2007, pp. 35-78.

Spivak, G. 'Can the Subaltern Speak?' In Marxism and the Interpretation of Culture, edited by Cary Nelson and Lawrence Grossberg, 271-316. Urbana: University of Illinois Press, 1988. 
Thurton, R. American Indian Holocaust and Survival: A Population History Since 1492. Normal: University of Oklahoma Press, 1990. 


\section{EMERGENT INDIGENOUS IDENTITIES AT THE U.S-MEXICO}

\section{BORDERLANDS}

\section{T. Mark Montoya}

The creation of the U.S.-Mexico border was a long political process that began in the sixteenth century when England, Spain, France, and many indigenous groups were vying for control of North America, and ended in the mid-nineteenth century when the United States gained a large portion of Northern Mexico through war, annexation, and purchase (Martinez 1996). The Mexican War (1846-1848) - or the War of North American Invasion as it is known in Mexico - is usually considered the defining moment for the creation of today's border. Yet now, more than 150 years after the signing of the Mesilla Treaty (Gadsden Purchase), which effectively finalized the location of the border, anti-immigrant militants continue to frame the border as broken, inciting popular opinion and policy makers to support completing "the danged fence" (McCain 2010). This discourse reinforces anti-immigrant sentiment and produces a persuasive logic rooted in 'others' as not belonging to the nation-state (see, for example, Huntington 2004). Without regard for indigenous peoples, historical migration patterns, or for changing definitions of citizenship, these anti-immigrant voices are often fixated on the nation-state as the only means for discerning who counts today (M. Anderson 1996).

Scholars examining alternate forms of citizenship today often link discussions of citizenship to discussions of identity. The linkage is concerned with how people see themselves as citizens, how they act upon their citizenship, and how they narrate their understanding of themselves in other aspects of life (Jones and Gaventa 2002, 13; Isin 
and Wood 1999). ${ }^{1}$ The assumption is that the concepts of citizenship and identity are complementary and that each person and group experiences and practices citizenship in different ways (Mouffe 1992; Isin and Wood 1999). To elaborate, I turn to Chantal Mouffe's (1992) oft-cited conceptualisation of identity as a starting point for discussing the linking of citizenship and identity. Mouffe argues that scholars should consider identity as a collection of 'subject positions' (such as female, Mexican, Muslim, etc.), each of which is only a portion of one's identity, and each portion influences the other. For instance, a Mexican woman and a Canadian woman - while both women - might understand the idea of being female differently (Mouffe 1992; see also Jones and Gaventa 2002, 14). Consequently, one can view both women's subject positions in relation to the dominant identities around them. It is subject positions that influence their overall worldview. Thus, individuals produce a sense of group political identity (citizenship) through identification with others who hold similar subject positions. In this case, a "citizenship" identity becomes dominant when a particular subject position is drawn upon in a politicised citizenship action (for example, a women's movement). Mouffe merges citizenship and identity in a way that advances a "master political identity" $(1992,12)$.

In a different conception of citizenship as an identity, Judith N. Shklar (1995) suggests that there are inherent contradictions about the meanings of American citizenship - the case of slavery in the United States provides a prime example. While the United States was asserting inclusive political rights, the country systemically denied those rights to slaves: denying them the right to vote and the right to

\footnotetext{
${ }^{1}$ Identity scholarship asserts that the way people understand themselves as citizens has an important effect on their awareness of their rights and obligations and, more importantly, on how, why and whether they participate as citizens (Jones and Gaventa 2002: 13).
} 
earn. "Under these conditions," she writes, "citizenship in America has never been just a matter of agency and empowerment, but also of social standing as well" (Shklar 1995, 2). The central tenet of her argument is that American citizenship is both a matter of public respect and of social standing (as opposed to using the term status). Furthermore, she argues that some citizens are still denied full citizenship - the right to vote and the right to earn - on the basis of their race, class and/or gender. Thus, one's standing differentiates full citizens from those who are unfit for full citizenship. The struggle for citizenship involves, then, a continuing battle to destroy the barriers of full citizenship, which remains exclusive in the United States. As Shklar writes, "There is nothing equal about social standing in general. Nothing more unequally distributed than social respect and prestige. It is only citizenship perceived as a natural right that bears a promise of equal political standing in a democracy" $(1995,57)$.

Evelyn Nakano Glenn's examination of Mexicans in the Southwest after the U.S.-Mexico War is also revealing of the inclusive/exclusive potential to discriminate in the everyday. ${ }^{2}$ The Treaty of Guadalupe Hidalgo, which ended the war in 1848, guaranteed that Mexicans who stayed in the newly acquired territories of the now U.S. Southwest would enjoy full rights as U.S. citizens. At the local level, however, their treatment was mixed. Some state constitutions granted full citizenship status to 'white' citizens of Mexico but not necessarily to those determined as "mestizo" - or those being of indigenous descent placing Mexican Americans in a precarious situation. Even those who were able to 'buy' their status were nonetheless often viewed as inferior.

\footnotetext{
${ }^{2}$ Glenn offers three compelling case studies, spanning the 1870 through the 1920 s that examine political and social relations between whites and blacks in the South, Mexicans in the Southwest and Japanese in Hawaii, and particularly how the often tumultuous relationships shaped ideas of citizenship.
} 
Also enlightening is that Mexicans, like 'blacks' in the South and the Japanese in Hawaii, all found various ways to challenge the exclusionary practices of citizenship. For instance, Mexicans were able to create separate spaces through social, cultural, and mutual aid societies. They also organised cultural festivals, celebrated Mexican holidays, sang native songs, and produced vernacular presses. Finally, they participated in protests and strikes often bringing together Mexican and Mexican American workers. As Glenn writes, they began "to advance a concept that is now called cultural citizenship - the right to maintain cultures and languages that differ from those of the majority without compromising membership in the American community or the civil, political, or social rights attached to membership" (2002, 189; emphasis mine).

\section{Cultural Citizenship}

Redefining citizenship is an ambitious project; however, the authors in the Latino Cultural Citizenship (1997) volume do not seek to redefine it. Instead, they seek to reveal the parts of citizenship that have been overtaken by legalese including rights, culture, empowerment, community, and membership. In addition, the works make clear the connection of citizenship to race, and particularly to power. The authors challenge us to consider the ways Latina/os in the United States are denied legal citizenship and ways to practise it by specifically examining and illustrating the actions and voices of Latina/o communities themselves. According to William V. Flores and Rina Benmayor, "Cultural citizenship names a range of social practices, which taken together, claim and establish a distinct social space for Latinos in this country" $(1997,1) .{ }^{24}$ Hence, the authors

\footnotetext{
${ }^{24}$ The argument the authors make is that this distinct social space is fluid and continual, and that the complexities of the Latina/o experience in the United States is at the same time racial, cultural, and linguistic. They also point out that
} 
examine the (sup)posed threat by Latina/os to the economic, political, and cultural character of the United States, primarily because Latina/os are often deemed as disuniting and devaluing U.S. culture, if not contributing to a mutation of the American ideal (Flores and Benmayor 1997, 4). In short, Latina/os are "different". In terms of the cultural citizenship approach, however, the authors see difference as a resource, not as a threat. The authors also contend that citizenship itself, is a very complex matter given that Latina/os were and are treated as second-class even when they are born in this country or branded as illegal when they are not. Thus, their point is not only to examine the cultural politics of citizenship but also to illustrate that citizenship rights and human rights cannot be separated.

The term "cultural citizenship" is attributed to Renato Rosado who criticized interpretations of culture as stagnant and for misrepresenting the direction and dynamics of actual cultural change (1985, 1989; cited in Flores and Benmayor 1995, 11). To examine cultural citizenship, the authors, in short, also introduced the concepts of agency, empowerment, and community as necessary for the social (re)production of citizenship forms. Flores and Benmayor continue, "Cultural citizenship can be thought of as a broad range of activities of everyday life through which Latinos and other groups claim space in society and eventually claim rights" $(1995,15)$. Thus, the concept of cultural citizenship goes beyond existing theories of acculturation, assimilation, multiculturalism, and pluralism. In addition, cultural citizenship incorporates a number of cultural practices that become central to affirmation for citizenship rights.

conquest and colonization are often overlooked when considering that the American continent is also the Latina/o "homeland." 
In a further elaboration of the concept of 'cultural citizenship', Renato Rosaldo's Cultural Citizenship in Island Southeast Asia (2003) is about indigenous peoples and belonging in the hinterlands of Indonesia, Malaysia, and the Philippines. The authors of the edited volume offer examples of how hinterland minorities "embrace, challenge, and transform imposed ideologies and policies" of the "electoral politics, national language, religious inclusion, educational access, and codification of national law" of their respective nationstates (Rosaldo 2003, 2). Rosaldo writes, "In Latino contexts the term cultural calls attention to the range of claims that citizens (especially groups subordinated by race, gender, and class) make against the state" $(2003,3)$. He continues:

The term citizenship ranges from the formal rights of citizens with respect to the state, such as voting, to more colloquial or vernacular matters that revolve, for example, around the distinction between first- and second- class citizens or the desire for recognition as a full member of a group. The contexts for the latter issues thus include the interactions in everyday environments, such as the workplace, churches, schools, and friendship and family networks. (Rosaldo 2003, 3)

In this case, cultural citizenship is seen as a continual process striving for and resisting belonging and not belonging. Important to the overall theme of the book is Rosaldo's development of Clifford Geertz (1973) and Benedict Anderson's (1991) conceptions of nationalism. He takes issue with Geertz concept of "primordial sentiments" as "constructed to seem natural" $(2003,4)$ and takes issue with Anderson for ignoring minorities and non-elites in his oft-cited discussion about nation-building by focusing solely on metropolitans and the elite.

Building upon the concept of cultural citizenship, Eric V. Meeks (2007) examines citizenship in terms of racial subordination, and the cultural politics of resisting that subordination in Arizona's 
borderlands. For Meeks, the once fluid racial categories of Arizona's borderlands were fixed by the project of nation building, as the territory was both rapidly moving toward capitalist development and statehood. The study underscores how citizenship in the borderlands has been obscured by strict racial categorisation. Hence, the citizenship rights of non-white Arizonans - the indigenous and ethnic Mexicans - suffered greatly. ${ }^{25}$ These groups were often relegated to either a second-class citizenship status or even regarded as noncitizens - a status born of racism and nativist sentiment. "Groups such as the Yaquis, Tohono O'odham, and ethnic Mexicans," writes Meeks, "became 'border citizens' - people whose rights of belonging were in question, leaving them on the margins of the national territory and of the American society" (2007, 11). What is more important, however, is that these groups, sometimes together and sometimes against each other, continuously challenged white structural dominance. He continues, "They were 'border citizens' both because of restrictions imposed on them and because they were redefining with it meant to belong to the U.S." (Meeks 2007, 11). ${ }^{26}$

\footnotetext{
${ }^{25}$ It is important to note that Meeks and others (see Gutierrez 1995) exemplify how Mexican American and Anglo relations worked at conflicting levels. To protect their citizenship rights, Mexican Americans often made claims to whiteness, and in many cases Mexican Americans were legally white. Yet, Mexican Americans were effectively nonwhite when claiming these rights.

${ }^{26}$ David G. Gutiérrez (1999) offers perspectives on the complex formation of widely held nationalist attitudes and the political orientations of people in the U.S.-Mexico borderlands, to also include non-cooperation. Gutiérrez argues that ethnic Mexicans were forced to adapt to increasingly sharp racial, cultural, and class distinctions in the United States. Adaptations included collective identity and solidarity as to claim new forms of nationality and citizenship (Gutiérrez 1999, 487). Gutiérrez continues "ethnic Mexicans were increasingly forced to devise defensive strategies of adaptation and survival in an intermediate, 'third'
} 
Similarly, with southern Arizona's borderlands as the setting, Katherine Benton-Cohen (2009) examines the racial structures and sheds light on how these structures have shaped the current immigration debate and in particular how they have defined citizenship. ${ }^{27}$ She writes, "At the border, 'American' was and is simultaneously a local, national, racial, and ideological category" (Benton-Cohen 2009, 7; emphasis mine). Examining how the groups and outside forces such as the market historically constructed notions of citizenship, she suggests that white identity - itself an identity open to various interpretations - and the various privileges that come with the identity, is consequently intertwined with the term 'American'. As such, whiteness is often utilised to define citizenship, and hence exclude non-white groups from certain rights and from particular places. We are left with some hope however, as Benton-Cohen concludes, "though racial and citizenship formations have an overwhelming and heartbreaking command in our lives, these conditions have changed" $(2009,274)$. Indeed, cultural citizenship is relevant here to emergent identities, particularly as a more amorphous cultural and social notion of belonging.

\section{Chicana/o Identities and Indigeneity}

The U.S.-Mexico borderlands are, at the same time, culturally distinct from and culturally a part of the United States and Mexico. As such,

social space that was located in the interstices between the dominant national and cultural systems of both the United States and Mexico” (Gutiérrez 1995, 488).

27 "Are you an American, or are you not?" These are words spoken by Cochise County Sheriff Harry Wheeler's in his infamous Bisbee Deportation round-ups, and these words drive Benton-Cohen's (2009) study. Building upon the scholarship that discusses the formation of race and nation in the United States, Benton-Cohen looks at the interactions among the various ethnic subpopulations in Cochise County; particularly, Indians, Mexicans, and Europeans. 
the borderlands continue to be an area where its 'citizens' customarily accept it as a cultural, political, and an economic space while simultaneously denying that space, by figuratively and literally building fences (see Vélez-Ibáñez 1996, 4-5). Symbolising the inherent contradiction of the borderlands is the question of what it means to be 'Hispanic' in the United States. Hispanics or Latina/os are white, they are black, they are Asian, they are indigenous, and they are multiple parts of these groupings in various combinations. Moreover, as part of the larger Latina/o categorisation, Mexican-Americans are both Mexican and American, and in many cases can and will self-identify under a number of changing and interpretive categories. These emergent identities beg the question as to whether Hispanics and Latina/os are an ethnic group, primarily because most are of mixed ancestry. Another issue is that Latina/os are often forced choose the traditional racial categories employed in the Unites States, which privileges whiteness over blackness and indigeneity. Finally, MexicanAmericans as mixed peoples or Mestiza/os are not only of indigenous heritage but are also often indigenous to the borderlands. ${ }^{28}$ When it comes to citizenship, the perceived threat is indigeneity - brown skin, indigenous cultures, languages, and so on. In other words, it is the otherness of the Mexican-American as an 'Indian' not a European that often makes them not belong to any particular citizenship regime, though the borderlands are theirs.

How Americans view Mexicans, and vice versa, is not at issue, but how belonging to the borderlands becomes associated with being the Other. This is an important issue, given that Mexican-Americans can both belong to the borderlands and are often 'other' to either side of the border - not considered fully Mexican or American. An examination of Mexican-Americans is an important point of entry for

\footnotetext{
${ }^{28}$ See Harris's discussion on Creole communities in this volume.
} 
a deeper discussion of citizenship issues in the borderlands. I am not, however, saying simply that being Mexican-American is the alternative-citizenship. Instead, I have set out to map a conceptual space in which we as scholars can engage in new conversations around the construction of citizenship. ${ }^{29}$ MexicanAmericans, or specifically in this case Chicano/as, can open a dialogue about the system to change the status and meaning of what is the held view of citizenship. ${ }^{30}$

Chicano/a identity is one that often focuses on the political nature of the group and of self, and moreover, one that often privileges an indigenous view of self and group. Implicit in the political overtones of Chicanismo is the idea that for many Chicano/as, the borderlands are contested grounds. Many Chicano/a scholars view the borderlands as a site of political and cultural conflict - a contested terrain shaped by changing individual and collective definitions of belonging and not belonging to the borderlands (see, for example, Vigil 1998). For this reason, many Chicano/as often feel that it is tougher to be a MexicanAmerican than to be a Mexican or an American, because on both sides of the border, they are often viewed with negative stereotypes. The

\footnotetext{
${ }^{29}$ What is understood as reality is socially constructed should not suggest that these constructions of reality do not mirror, perform, and reify relations of power. Social constructions illustrate how certain agents play a privileged role in the (re)production of these realities.

${ }^{9}$ Dependent on bias, there will always be a variety of definitions for the term Chicano/a. The scholarly world, at large, has come to view the term Chicano/a as a political term. As a distinctive 'identity,' Chicano/a identity is relatively young, having taken shape in two generations or so after the conclusion of the U.S.Mexico War in 1848. Until the Chicano Movement of the 1960s, MexicanAmericans were virtually invisible. The Chicano Movement added widespread consciousness-raising with regard to the identity of Mexican-Americans. The outcomes of this new self-awareness and struggle for identity informed a history of Chicano/as that went beyond 1848 (the signing of the Treaty of Guadalupe Hidalgo) to the emblematic year of 1492 .
} 
main issue for many Chicano/as is the belief that the creation of the 1848 border split them up - and made them hyphenated Americans. ${ }^{31}$ Chicano/as thus are embodiments of a complex fate shared by those born 'other -American', hybrids always living in the hyphen. As Benjamin Alire Saenz suggests, however, searching for an identity and accusing Chicano/as of playing identity politics is wrong as everybody engages in identity politics (1997, 73-75). He rhetorically poses, "Why is identity politics inescapable? Because we live in a shitty, disgusting world that produces and reproduces appalling inequalities, a society that helps create suspicions of 'others'” (Alire Saenz 1997, 79).

The Chicano/a thus becomes important to the discussion of the possibilities of an alternative-citizenship, primarily because Chicano/as are said to span two nation-states. ${ }^{32}$ As James Diego Vigil writes, "There are books on Mexico and works on the American Southwest, but few books attempt to grapple with and unravel the complex strands of Chicanos, as the 'in-between' people, who straddle both nations with a thin borderline separating the two" $(1998,2)$.

The proximity of Mexico to the United States is illustrative of Chicano/as' problematic relationship to traditional forms of citizenship. Adding a feminist dimension, Norma Alarcón et al. write that, "the nation-state sharpens the defining lines of citizenship for women, racialized ethnicities, and sexualities in the construction of a socially stratified society" (1999, 1; see also Irigaray 1985, 171). In other words, citizenship vis-à-vis the nation-state is, at the same time, the denial and consolidation of sexual and racial difference. In the same vein, Laura Elisa Pérez continues:

\footnotetext{
${ }^{31}$ Most Mexican-Americans, however, are descended from immigrants and not from the inhabitants of the 1848 borderlanders.

${ }^{32}$ Here, I am using the term Chicano/a interchangeably with the term MexicanAmerican.
} 
Chicana/o cultural practices have operated in disordering, profoundly disturbing ways with respect to dominant social and cultural, spatial and ideological topographies of the "proper" in the United States. Cultural practices that code themselves as "Chicana/o" function as paradoxes within the ordering logic of dominant U.S. discourse, for they bear the identifying graffiti of a tenacious, socially and economically overdetermined biculturality, so do they operate bidiscursively, articulated both within and without the oppressive ideological territories of "Occupied America. $(1999,19)$

The Chicana feminist critique is a useful starting point for rethinking citizenship away from a solely binary opposition between 'us and them', to questions of difference, power, and knowledge (Aldama and Quiñonez 2002; see also, Moraga and Anzaldúa 1981; Anzaldúa 1987; Alarcón 1997; Trujillo 1998). In the process of challenging existing citizenship paradigms, a new political identity - a borderlands identity - emerges to challenge both the racism of Anglo-American feminism and the sexism of ethnic nationalist movements. ${ }^{33}$ An emergent border identity is also frequently used to explain the problems with confining and separating human communities, and to explain efforts to break from the confinement and separation.

Reverberating the arguments, Arturo J. Aldama and Naomi H. Quiñonez write, "The U.S.-Mexico border zone is a site that is lived and expressed by those who reside in the physical/discursive margins generated by the edge of two nation states" (2002, 1; emphasis mine). They argue that for more than 500 years, the Americas have attempted to deal with colonial and neocolonial subjugation, and for more than 150 years, Chicanos/as have dealt with a continued subjugation. ${ }^{34}$

\footnotetext{
${ }^{33}$ A borderlands identity should not assume just one singular identity, but instead assumes multiple and fluid identities.

${ }^{34}$ Like the year 1492, the year 1848 marks an important moment in which

Chicano/a lives were dramatically changed. Of course, if we are to be historically
} 
One way subjugation is dealt with is through cultural productions that have created a discursive space (through art, media, music, and other forms of popular cultural production) to articulate various forms of resistance to physical barriers. As the authors point out, it is "a resistance to the multiplicity of oppression across race, class, gender, and sexuality" (Aldama and Quiñonez 2002, 3). Arturo J. Aldama continues, "Chicana/o border studies, devoted to understanding the complex dialectics of racialized, subaltern, feminist, and diasporic identities and the aesthetic politics of hybrid mestiza/o cultural production, is at the vanguard of historical, anthropological, literary, cultural, artistic, and theoretical inquiry" $(2002,11)$.

\section{Chicano/a Studies}

For many Mexican and other Latin Americans, crossing the border into the United States not only means crossing from one country to another but crossing from one system of classification (national/regional) to another (pan-ethnic). This is to the extent where many border-crossers experience ethnogenesis, whereby they are often seen as sharing a common ethnic identity, despite diversity. ${ }^{35}$ Crossing boundaries, then, is characterised by crossing not only into a different state or territory, but crossing into different cultural systems (Anderson 1996, 4-6). Indigenous hybrid cultures have emerged that are shunned by both hegemonic centers. Yet, the search for identity

specific about identity, Chicano/a might not be the best term here, since, in those times it was not used.

${ }^{35}$ In addition, the already complex Mexican-American ethnic identity was compounded in the 1980s when the U.S. government began to use a new official and encompassing classification-Hispanic. The Hispanic label included all Mexican-Americans, Cuban-Americans, Puerto Ricans, Central and South Americans, and sometimes, even Spaniards, in spite of each group's distinctive histories. 
has taken on many forms. Lawrence A. Herzog suggests that the importance of culture is magnified in the U.S.-Mexico borderlands. And on the U.S.-Mexico border, Chicano/as often claim two, and sometimes more, nation-states. More importantly, Chicano/as often create unique spatial formations that have evolved under the different cultural codes and conditions of Mexico and the United States (Herzog 1990, 7). ${ }^{36}$ Another way to consider an alternative-citizenship in the U.S.-Mexico borderlands, then, is to look to Chicano/a studies, which can help enable us to identify the numerous possibilities of an alternative-citizenship. Chicano/a studies have a long and wideranging history, however, it can be noted for its insistence on both cultural and political empowerment.

Today Chicano/as find themselves at a critical crossroad. Although they have accomplished much, many more struggles remain. ${ }^{37}$ One way we that can achieve this, as John A. Garcia points out, is through the penetration of Chicano/as into decision-making institutions (Garcia 1996). Maria Rosa Garcia-Acevedo continues:

Looking toward a new millennium, the Chicano community is faced with a challenge that goes beyond the U.S. border: the sustaining of links with its homeland, Mexico. This problematic relationship, which began in the mid-nineteenth century ... has had a fascinating

\footnotetext{
${ }^{36}$ To be sure, there are also Anglo, indigenous, and other borderlanders. My focus here, however, is on a varied and diverse group of people I identify broadly as Mexican-American. Like the many indigenous groups in the borderlands, Mexican-Americans have experienced, confronted, and build barriers on the border (see Gutiérrez 1995). At the same time they have often dealt with the citizenship regime, as citizens, as non-citizens, and as second-class citizens. ${ }^{37}$ The most notable achievements are not by way of management or ownership, but as the bulk of the work force, especially in the borderlands (see de la Torre and Rochin 1990). Indeed, we must address substantial problems of poverty and exploitation.
} 
but complex evolution. Prior to the advent of the Chicano Movement, few formal ties existed between Mexico and the Chicano community. Chicanos had been too preoccupied with national questions such as civil rights, education, and fair employment practices to turn their attention to foreign policy concerns. Some were also discouraged by the existence of discriminatory Mexican attitudes toward Chicanos. Moreover, for many Chicanos, Mexico was an unknown, uninterested, and distant homeland. $(1996,130)$

At issue is that Chicano/a identities in the United States are constructed and developed through various discourses, and that these constructions are often informed and driven by racist, antiimmigrant, and anti-indigenous sentiments. The relationship between Chicano/as and citizenship thus raises important questions with regard to notions of equality, justice, power, and race/ism. In addition, while immigrant status is often an issue of importance for Chicano/as in the workplace, being undocumented is not a significant issue in the workplace because discriminatory conditions often exist for Mexicans, Mexican-Americans, indigenous peoples, other ethnic minorities and for women despite legal status. As the classic principles of U.S. democratic theory purport, full incorporation into U.S. society requires that all discriminatory barriers be eliminated. When applying these principles to the struggle for Mexican-American equality under the law, it is clear that many Chicano/as have arguably not been granted 'full' citizenship in the United States regardless of their legal status (Valencia, et al. 2004, 15-16).

\section{Aztlán: The Emergent Indigenous Identity}

To understand an alternative citizenship, it is important to understand one's experiences as everyday sites of negotiation with borders. While barriers are a strong feature of most border peoples' experiences, negotiation with borders are potential points for border crossings - 
overcoming or at least coping with barriers from day to day. Much of the citizenship and borderlands literature highlights barriers and conflict, and it has been argued that there is an inherent conflict among and between all types of citizens (see, for example, Vila 2000). What is important to note here, as Rosaldo writes, is that "full citizenship and cultural visibility appear to be inversely related. When one increases the other decreases. Full citizens lack culture, and those most culturally endowed lack full citizenship" $(1989,198)$.

Furthermore, as C. Alejandra Elenes points out, the problem with mainstream discourses is not that they fail to take into account differences of race, class, gender, and sexuality, but that they fail to adequately theorise and even fail to acknowledge such categories as "white," "male," "heterosexual," and "middle class," and their interconnectedness $(2002,254)$. The American mainstream has also forged an unnecessary phenomenon in race and ethnic relations in the borderlands. ${ }^{38}$ Thus, citizenship is indeed a racialised concept. U.S. history is marked by structures that have determined a continuation of antagonism against 'others.' For example, as Carl Gutierrez-Jones explains, "The process by which Chicanos have become institutionally and popularly associated with criminality has had a long and complex history that is intimately related to their very construction as a social group in the United States" (Gutierrez-Jones 1995, 1). The Chicano/a experience also stems from the dynamics of geographical and

\footnotetext{
${ }^{38}$ Negative racial/ethnic representations of Mexican-Americans in the United States stretch back before the U.S.-Mexico War. Mexicans have long been seen as a mongrel race in contrast to their northern neighbors, not only in skin color but also in morality. After the war, Mexicans living in the United States became Mexican-Americans, inheritors of a Mexican cultural identity but members of a stratified U.S. society (see Pettit 1980, 12).
} 
socioeconomic backdrops. ${ }^{39}$ The strength of Mexican American culture, however, was that it could draw from its motherland. Still, assimilation has had major implications for some Chicano/as. Many experiences left them between a culture they left behind and a society that was unaccepting of them. ${ }^{40}$ On the other hand, other Chicano/as took to separatism either to migrate to Mexico, or in extreme cases, to re-conquer the U.S. Southwest (Vigil 1980, 162-166).

Because manipulation and destruction of oppressed peoples are inherent to colonialism, Franz Fanon postulates that the process of decolonization involves the creation of a national consciousness $(1979,210) .{ }^{41}$ Following this argument, Sarah Ramirez contends that

\footnotetext{
${ }^{39}$ Since the consolidation of the northernmost area of Mexico into the United States, American culture itself has gone through major changes. James Diego Vigil writes, "Industrialization and urbanization transformed a primarily agrarian society into an international military and political power .... Social and economic sanctions were therefore developed to impede the entrance of ethnically and culturally 'different' people into the mainstream of American society" (Vigil 1980, 156). This put pressures on "others" to assimilate and accept U.S. bourgeois-
} values.

${ }^{40}$ Along with this, many Mexican citizens often do not take Chicano culture seriously. The impression of border culture in the interior of Mexico is that of unconventional caricatures. The borderlands for them are the area where American influence and the appropriation of American culture by Mexicans are at its greatest levels. They also accuse Chicanos of being fully aware of bourgeois (read U.S.) values and defending these values as their own. Thus, Chicanos, for many Mexicans, have lost their identity (see Monsivais 1978, 64-67). Finally, rather than looking at their Mexican origin as a criterion of patriotism, MexicanAmericans often view it as the reason for their oppression.

${ }^{41}$ Franz Fanon suggests that nationalist consciousness is an attempt for the colonized to resist colonization and hence reclaim self-determination. Here a recuperation of the past is necessary. As colonial (post-U.S.-Mexico War) and neo-colonial (subject to economic and legal exploitative mechanisms) subjects in the United States, many Chicano/as often utilized an indigenous recuperation 
what we see in Chicano/a nation-building is a bias of shared cultural indigenous heritage, a common language - a mixture of Spanish and English with some use of the various indigenous languages of Mexico, connection to/ownership of the land, and a political, social, and historical displacement (2002, 224). The Chicano/a homeland - an indigenous homeland - Aztlán, then becomes a unifying concept and base for Chicano/a nationalist discourse and of cultural pride, identity, and presence in the United States. Ramirez suggests that saying the word "Aztlán" also became a basis of commitment toward acknowledging and claiming indigenous imaginations as part of the Chicano/a reality $(2002,224-225)$.

However, the point that Ramirez makes is that this 'imagined' Chicano nation "served to subjugate, define, and control Chicanas, revealing a contradiction between ideology and praxis" (2002, 225). While nation-imagining implies uniformity, many have been uncritical of the official discourses of the Chicano Movement - except for the Chicana feminists. ${ }^{42}$ Ramirez writes:

Asserting a living Chicana theory: a theoretical discourse that considers the intersections of race, class, gender, sexuality, and religion, among other factors, Chicana feminism integrates these complex intersections of the Chicana social quandary, creating alternative spaces to the controlling images and spaces of ethnocentric, ethnonostalgic, and patriarchal nationalist discourses. While also drawing from indigenous cultures and philosophies,

(see, for example, Vazquez and Torres 2003, 334). Adding to this, Benedict Anderson suggests that nation building is an extension of imagined "natural ties" (1993, 143).

${ }^{42}$ In the course of cultural politics and the like, I have always believed that Chicana Feminism was ahead of its time; critiquing patriarchy, sexism, homophobia, and the general disregard for difference within some of the various stages of the Chicano Movement. 
Chicana aesthetic productions employ its revisionist critique and create empowering images of personal and communal self-identity. (Ramirez 2002, 226)

\section{A Note on Chicana Feminist Poetry}

Nevertheless perspectives on Chicana thought are numerous. Even today, many forms of political action exist, ranging from formal or institutional politics, such as electoral politics, to various forms of rebellion, mobilisation and organisation, protest, and struggle (VélezIbáñez 1996, 92-93). There are also other forms of political struggles that often revolve around cultural place, space, and processes that are not often understood. They are often filled with contradictions and internal opposition, and sometimes are never actually realised as a social movement. ${ }^{43}$ As Beezley and Curcio-Nagy write, "Marginal peoples - the poor, the enslaved, women - historically have manipulated cultural forms to their own benefit" (2000, xii). Even while the political importance and political impact of (popular) cultural studies have been subject to scrutiny, it has endured as an edifying, social, and political practice. ${ }^{44}$

\footnotetext{
${ }^{43}$ Within cultural and ethnic studies, African Americans and the blues seems to be the most common example of cultural resistance in the United States (see, for example, Palmer 1982).

${ }^{44}$ In their introduction, William H. Beezley and Linda A Curcio-Nagy identify five elements that are prevalent in the study of popular culture in Latin America. These are, "1) the invention of traditions, 2) the creation of national identity, which some call the imagined community, 3) the formation of gender roles, 4) the prevalence of ethnicity-a sharper designation that the category of race--and 5) the dynamic interplay between textual deconstruction and performance analysis that is neither one nor the other but the relationship of the two" (Beezley and Curcio-Nagy 2000, xix). Popular culture, they write, refers "to the set of images, practices, and interactions that distinguishes a community" (Beezley and CurcioNagy 2000, xi). In this case, popular culture and its more politically overt
} 
Focusing on everyday struggles, the use of the poems offer a small sampling of the multiplicity of personal accounts and narratives through which borders are confronted and crossed. What makes poetry so interesting is that it is open to interpretation. Writing, explains Felipe de Ortego y Gasca "is a cultural act surrounded and impacted by historical forces. What is written depends on the motivations of the writer. As readers and critics, we cannot accurately discern those motivations, we can only approximate them" (2007, 345). Similarly, Francisco H. Vásquez and Rodolfo D. Torres (2003) note that the theme of language pervades all perspectives. Vásquez and Torres write, "this means that language, as it intersects power and becomes a discourse, functions much like a mountain, river, or forest. It determines to a large extent what can and cannot be said, where we can and cannot go" $(2003,75)$. While we may never truly know the role Chicano/a popular culture plays in challenging the citizenship regime, poetry and other cultural forms can freely explore the possibilities of an alternative-citizenship.

For example, This Bridge Called My Back: Writings by Radical Women of Color (1981), a collection of essays, poems, short stories, literary and autobiographical works, brought to light an on-going conflict that women of color were having with racialised civil rights

synonym national identity signify everyday culture. As Beezley and Curcio-Nagy write, "[Popular culture] identifies a set of behavioral practices with pervasive, ordinary character and acknowledges the general acceptance of these practices, their roots in common knowledge, and their frequent expression in nonwritten form" (2000, xi). In a similar approach, Bueno and Caesar ask, "What exactly is a national culture at the level of the popular? Is it separable from the state? Can it be ultimately coherent or not? Is it the stuff of dreams or of nightmare?" (Bueno and Caesar 1998, 11-12). They conclude that the "study of popular culture recovers the reality of a country ...." While popular culture often provokes some dispute about the construction of the nation, it continues to have the ability to construct a national identity. 
movements for ignoring women, gender, and sexualities, and conflict with women's and feminist movements for ignoring race, ethnicity, and other identities. The editors Cherrie Moraga and Gloria Anzaldúa, as well as their many contributors, were brought into the literary, cultural, and political spotlight, as their book provided "a catalyst, not a definitive statement on "Third World Feminism in the U.S." (1981, xxvi). Along these lines, the poems echo thoughts about migration, borders, cultural identity, indigeneity, and citizenship - all from Mexican American women poets who have variously been called Chicana feminists and who generally utilize a Chicana feminist perspective. The term "Chicana feminist perspective", writes Yvonne Yarbro-Bejarano, "implies certain similarities with and differences from either an exclusively 'feminist' or 'Chicano' perspective” (2007, 364). Yarbro-Bejarano continues:

While sharing with the feminist perspective an analysis of questions of gender and sexuality, there are important differences between a Chicana perspective and the mainstream feminist one with regard to issues of race, culture and class. The Chicano perspective, while incorporating these important facets of race, culture and class, has traditionally neglected issues of gender and sexuality... While this may seem painfully obvious, the assertion of this project in Chicana writing is crucial in combating the tendency in both white feminist and Chicano discourse to see these elements as mutually exclusive. By asserting herself as Chicana or mestiza, the Chicana confronts the damaging fragmentation of her identity into component parts at war with each other. $(2007,364)$

The search for a place and space is an on-going theme in Chicana literature. ${ }^{45}$ This search is of particular importance for Mexican origin

\footnotetext{
${ }^{45}$ Likewise, mural art continues to fill in place and space for people in the borderlands. Mexican-American mural art recreates symbols and myths from south of the border to declare a sense of history, as well as utilises imagery from
} 
writers (see also, for example, Anzaldúa 1987, 1990; Gomez- Peña 1996; R. Rodriguez 1996; L. Rodriguez 2003). ${ }^{46}$ Literature of and from the borderlands is also notable for its insistence on voice, whereby voice becomes the means by which new spaces and places are created or redefined. It is here where multiple emerging identities and multidimensional paradoxes are experienced. Indeed, these literatures defy categorisation. Each writer creates a mixture of reality and fantasy. Moreover, each writer assists in creating images of the borderlands that is continuously emerging. Beyond the geographic and political border that separates the United States and Mexico, Mexican-American writers have exposed many other 'borders' in their search to survive within the larger realm of U.S. society, and to create and exhibit their sense of belonging.

In Lorna Dee Cervantes's (1981) Poem for The Young White Man Who Asked Me How I, an Intelligent, Well-Read Person, Could Believe In the War Between Races, the author speaks to her experience of race and of racism in the United States. While a personal narrative, the poem also addresses the differences between the dominant society

north of the border such as farm workers, U.S. activist heroes, and "social bandits" to declare as sense of community. Mural art, thus, often goes beyond the confined boundaries of legitimizing authorities and set issues. Throughout the U.S. Southwest, thousands of walls have been covered with community-created symbols and themes, which are often representative of a whole population, rather than being an individualized artistic expression (Vélez-Ibáñez 1996, 244-245). At the same time, mural art continues to be a vibrant expression of political consciousness. Politically, murals document cultural persistence and continuance; by expressing liberation, self-determination, and multiculturalism murals provide a multi-vocal means to literally and figuratively fill in places and spaces (Vélez-Ibáñez 1996, 263-264).

${ }^{46}$ For a great discussion of narrative and semi-narrative works by borderlands writers see Vélez-Ibáñez's (1996) chapter entitled “The Search for Meaning and Space through Literature," pp. 212-243. 
(whites) who can ignore race and racism and others (people of color) who are reminded of their differences on a daily basis. Cervantes writes:

\author{
I believe in revolution \\ because everywhere the crosses are burning, \\ sharp-shooting goose-steppers round every corner, \\ there are snipers in the schools.... \\ (I know you don't believe this. \\ You think this is nothing \\ but faddish exaggeration. But they \\ are not shooting at you).
}

(Cervantes 1981, 229)

Consequently, as the previous lines illustrate, Cervantes describes the ongoing situation of being a U.S. citizen, yet not fully belonging to the nation. She concludes:

Outside my door

there is a real enemy

who hates me.

[...]

Every day I am deluged with reminders

that this is not

my land

and this is my land.

I do not believe in the war between races

but in this country

there is war.

(Cervantes 1981, 230)

This and other poems are timely reminders of the contradictions embodied and experienced by Chicana women who live within various intersecting and overlapping borderlands (geographical, sexual, gendered, racial, class, and so on). More importantly, poems 
draw attention to the borderlands experiences of the writers as not being fully recognised or constituted as full citizens. By engaging the political and cultural aspects of their identities, the writers offer both fictionalised and autobiographical testimonies to address the lack of citizenship they experience in mainstream feminisms and Chicano nationalist discourses. Still, the poems are not wholly limited to the experiences of the writers in particular, or of Chicanas specifically. And while quite approachable, the poems provide a deep, complex, and encompassing counter-narrative to the citizenship regime. As Delberto Dario Ruiz writes, "The border, immigration regulations, and restrictions on naturalization and citizenship contribute to the construction of racialized and gendered Xicanas/os....As such, the Xicana/o has been historically cast into an 'alien-ated' relation to the category of citizenship" $(2002,361) .{ }^{47}$ Chicana feminist poetry allows us to rethink language as a given process of rules and to acknowledge that speaking and writing are culturally produced discourses. The language of Chicana feminist poetry can and often includes English, Spanish, indigenous languages, slang, the creation of new words, and the mixing of genres to articulate complex ideas. What the language does is reveal the colonising aspects of the 'rules' at play when we express a position on who we are, or what we can be today (see also, Dario Ruiz 2002).

\section{Conclusion}

The relationship between borders and emergent indigenous identities is an embattled zone. Traditional conceptions of the nation-state often emphasise territorial boundaries, but as migration patterns show, people are not always bound to one territory. This is not a new notion. Territorial boundaries have never fully conformed to the movement of

\footnotetext{
${ }^{47}$ The term Xicana/o, here, is the same as Chicana/o.
} 
people (Newman 2000, 21-22). In this chapter, I proposed that borders can no longer confine citizens. Instead, alternative-citizenship forms may be emerging because of the people in borderlands. Indeed, citizenship is not the neutral concept that anti-immigrant advocates assume, primarily because they overlook the ways in which citizenship is constructed and more importantly overlook who gets to construct citizenship. Likewise, in linking power to citizenship, we see that identity formations including race, class, gender, and indigeneity all factor into the conception of citizenship, particularly in terms of who is granted full citizenship rights and who is not. An alternative citizenship of belonging is based on the claims made against a traditional citizenship of membership, which has often subordinated people based on their race, class, and gender. Traditional citizenship stands in the way of a fully open and democratic society because it is arbitrarily given to those with power, while many people of color, indigenous peoples, the poor, and women, remain second-class citizens, non-citizens, or both. Indeed, there is something significant about what it means to belong - politically, culturally, and socially and what I have tried to demonstrate in this chapter is that for most people this is often articulated through the complexities of emergent identities.

\section{References}

Alarcón, N. 'Traddutora, Traditora: A Paradigmatic Figure of Chicana Feminism.' In Dangerous Liaisons: Gender, Nation, and Postcolonial Perspectives, edited by A. McClintock, A. Mufti, and E. Shohat, 278-296. Minneapolis: University of Minnesota Press, 1997.

Alarcón, N., Kaplan, C. and M. Moallem. 'Introduction: Between Woman and Nation,' In Between Woman and Nation: Nationalisms, Transnational Feminisms, and the State, edited 
by C. Kaplan, N. Alarcon, and M. Moallem, 1-16. Durham: Duke University Press, 1999.

Aldama, A.J. 'Millennial Anxieties: Borders, Violence, and the Struggle for Chicana and Chicano Subjectivity.' In Decolonial Voices: Chicana and Chicano Cultural Studies in the $21^{\text {st }}$ Century, edited by A.J. Aldama and N.H. Quiñonez, 11-29. Bloomington: Indiana University Press, 2002.

Aldama, A.J. and N.H. Quiñonez. '¡Peligro! Subversive Subjects: Chicana and Chicano Cultural Studies in the $21^{\text {st }}$ Century.' In Decolonial Voices: Chicana and Chicano Cultural Studies in the $21^{\text {st }}$ Century, edited by A.J. Aldama and N.H. Quiñonez, 1-7. Bloomington: Indiana University Press, 2002.

Anderson, B. Imagined Communities: Reflections on the Origin and Spread of Nationalism. London: Verso, 1983.

Anderson, M. Frontiers: Territory and State Formation in the Modern World. Cambridge: Polity Press, 1996.

Anzaldúa, G. Borderlands/La Frontera: The New Mestiza. San Francisco: Aunt Lute Press, 1987.

Anzaldúa, G. Haciendo Caras/Making Face, Making Soul: Creative and Critical Perspectives by Women of Color. San Francisco: Aunt Lute Press, 1990.

Beezley, W. H. and L. A. Curcio-Nagy. Latin American Popular Culture: An Introduction. Wilmington: Scholarly Resources Inc, 2000.

Benton-Cohen, K. Borderline Americans: Racial Division and Labor War in the Arizona Borderlands. Cambridge: Harvard University Press, 2009.

Bueno, E. P. and T. Caesar. Imagination Beyond Nation: Latin American Popular Culture. Pittsburgh: University of Pittsburgh Press, 1998.

Cervantes, L. D. 'Poem for The Young White Man Who Asked Me How I, an Intelligent, Well-Read Person, Could Believe In the 
War Between Races.' In Writing on the Edge: A Borderlands Reader, edited by. T. Miller, 229-230. Tucson: The University of Arizona Press, 2003.

Dario Ruiz, D. 'Teki Lenguas del Yollotzin (Cut Tongues From the Heart): Colonial Impositions, Hegemonic Borders and Shifting Spaces'. In Decolonial Voices: Chicana and Chicano Cultural Studies in the $21^{\text {st }}$ Century, edited by A.J. Aldama and N.H. Quiñonez, 355-365. Bloomington: Indiana University Press, 2002.

De La Torre, A. and R. Rochin. 'Immigration Reform and Economic Deprivation of Hispanics.' Chicano Law Review 10 (1990): 113.

de Ortego y Gasco, F. 2007. 'Mexican American Literature: Reflections and a Critical Guide'. In Chicana/o Studies: Survey and Analysis, Third Edition, edited by D.J. BixlerMárquez, C.F. Ortega, and R.S. Torres, 345-362. Dubuque: Kendall/Hunt Publishing Company, 2007.

Elenes, C. A. 'Border/Transformative Pedagogies at the End of the Millennium: Chicana/o Cultural Studies and Education.' In Decolonial Voices: Chicana and Chicano Cultural Studies in the $21^{\text {st }}$ Century, edited by A. J. Aldama and N. H. Quiñonez, 245-261. Bloomington: Indiana University Press, 2002.

Fanon, F. The Wretched of the Earth: The Handbook for the Black Revolution that is Changing the Shape of the World, Translated by Constance Farrington. New York: Grove Press, 1979.

Flores, W. V. and R. Benmayor. Latino Cultural Citizenship: Claiming Identity, Space, and Rights. Boston: Beacon Press, 1997.

Garcia, J. A. 'The Chicano Movement: Its Legacy for Politics and Policy.' In Chicanas/Chicanos at the Crossroads: Social, Economic, and Political Change, edited by D.R. Maciel and 
I.D. Ortiz, 108-129. Tucson: University of Arizona Press, 1996.

Garcia-Acevedo, M. R. 'Return to Aztlán: Mexico's Policies toward Chicanas/os.' In Chicanas/ Chicanos at the Crossroads: Social, Economic, and Political Change, edited by D.R. Maciel and I.D. Ortiz, 130-156. Tucson: University of Arizona, 1996.

Geertz, C. The Interpretation of Cultures. New York: Basic Books, 1973.

Glenn, E. N. Unequal Freedom: How Race and Gender Shaped American Citizenship and Labor. Cambridge: Harvard University Press, 2002.

Gomez-Peña, G. The New World Border. San Francisco: City Lights, 1996.

Gutierrez, D. G. Walls and Mirrors: Mexican Americans, Mexican Immigrants, and the Politics of Ethnicity. Berkeley: University of California Press, 1995.

Gutiérrez, D. G. 1999. 'Migration, Emergent Ethnicity, and the 'Third Space': The Shifting Politics of Nationalism in Greater Mexico.' The Journal of American History - Rethinking History and the Nation-State: Mexico and the United States as a Case Study: A Special Issue 86. 2 (1999): 481-517.

Gutierrez-Jones, C. 1995. Rethinking the Borderlands: Between Chicano Culture and Legal Discourse. Berkeley: University of California, 1995.

Herzog, L. A. Where North Meets South: Cities, Space, and Politics on the U.S.-Mexico Border. Austin: University of Texas Press, 1990.

Huntington, S. P. Who are We?: The Challenges to America's National Identity. New York: Simon and Schuster, 2004.

Isin, E. F. and P. K. Wood. Citizenship and Identity. London: Sage Publications, 1999. 
Irigaray, L. This Sex Which Is Not One. Ithaca: Cornell University Press, 1985.

Jones, E. and J. Gaventa. Concepts of Citizenship: A Review. Brighton,: Institute of Development Studies, 2002.

McCain, J. 2010. 'McCain TV Ad: Complete the Danged Fence.' Retrieved April 30, 2012.

http://www.youtube.com/watch?v=r0lwusMxiHc

Martinez, Oscar J. U.S.-Mexico Borderlands: Historical and Contemporary Perspectives. Wilmington, DE: Scholarly Resources Inc, 1996.

Meeks, E. V. Border Citizens: The Making of Indians, Mexicans, and Anglos in Arizona. Austin: University of Texas Press, 2007.

Monsivais, C. 'Tin Tan: Pachuco’. Travesia. 3 (1994): 178-198.

Moraga, C. and G. Anzaldua. This Bridge Called My Back: Writings by Radical Women of Color. Watertown: Persephone Press. 1981.

Mouffe, C. 'Preface: Democratic Politics Today.' In Dimensions of Radical Democracy: Pluralism, Citizenship, Community, edited by C. Mouffe, 1-16. London: Verso, 1992.

Newman, D. 'Boundaries, Territory and Postmodernity: Towards Shared or Separate Spaces?' In Borderlands Under Stress, edited by M. Pratt and J.A. Brown, 17-34. London: Kluwer Law International, 2000.

Palmer, R. Deep Blues: A Musical and Cultural History of the Mississippi Delta. New York: Penguin Books, 1982.

Pérez, L. E. 'El desorden, Nationalism, and Chicana/o Aesthetics,' In Between Woman and Nation: Nationalisms, Transnational Feminisms, and the State, edited by C. Kaplan, N. Alarcon, and M. Moallem, 19-46. Durham: Duke University Press, 1999.

Pettit, A. G. Images of Mexican American in Fiction and Film. Austin: Texas University Press, 1980. 
Ramirez, S. 'Borders, Feminism, and Spirituality: Movements in Chicana Aesthetic Revisioning.' In Decolonial Voices: Chicana and Chicano Cultural Studies in the 21 $21^{\text {st }}$ Century, edited by A. J. Aldama and N. H. Quiñonez, 223-242. Bloomington: Indiana University Press, 2002.

Rodriguez, L. J. 'This Memory Begins with Flight.' In Writing on the Edge: A Borderlands Reader, edited by T. Miller, 59-63. Tucson: University of Arizona Press, 2003.

Rodriguez, R. 'Pocho Pioneer.' In The Late Great Mexican Border, edited by B. Byrd and S.M. Byrd, 211-224. El Paso: Cinco Puntos Press, 1996.

Rosaldo, R. 'Assimilation Revisited.' Working Paper Series, No. 9. Sanford, CA: Stanford Center for Chicano Research, 1985.

Rosaldo, R. Culture and Truth: The Remaking of Social Analysis. Boston: Beacon Press, 1989.

Rosaldo, R. Cultural Citizenship in Island Southeast Asia: Nation and Belonging in the Hinterlands. Berkeley: University of California Press, 2003.

Saenz, B. A. 'In the Borderlands of Chicano Identity, There Are Only Fragments.' Border Theory: The Limits of Cultural Politics, edited by S. Michaelsen and D.E. Johnson 68-96. Minneapolis: University of Minnesota, 1997.

Shklar, J. N. American Citizenship: The Quest for Inclusion. Cambridge: Harvard University Press, 1995.

Trujillo, Carla, ed. 1998. Living Chicana Theory. Chicago: Third Woman Press.

Valencia, R. A., S. R. García, H. Flores, and J. R.Juárez, Jr. Americans and the Law: ¡El pueblo unido jamás será vencido! Tucson: The University of Arizona Press, 2004. 
Vázquez, F. H. and R. D. Torres. Latino/a Thought: Culture, Politics, and Society. Boulder, CO: Rowman and Littlefield Publishers, 2003.

Vélez-Ibáñez, C. G. Border Visions: Mexican Cultures of the Southwest United States. Tucson: The University of Arizona Press, 1996.

Vigil, J. D. From Indians to Chicanos: The Dynamics of Mexican American Culture. Prospect Heights: Waveland Press, 1980.

Vigil, J. D. From Indians to Chicanos: The Dynamics of MexicanAmerican Culture, Second Edition. Prospect Heights: Waveland Press, 1998.

Vila, P. Crossing Borders, Reinforcing Borders: Social Categories, Metaphors, and Narrative Identities on the U.S.-Mexico Border. Austin: University of Texas Press, 2000.

Yarbro-Bejarano, Y. 'Chicana Literature from Chicana Feminist Perspective.' In Chicana/o Studies: Survey and Analysis, Third Edition, edited by D.J. Bixler-Márquez, C.F. Ortega, and R.S. Torres, 363-366. Dubuque, IA: Kendall/Hunt Publishing Company, 2007. 


\section{EMERGING AND SUBMERGING: EBBS, FLOWS, AND \\ CONSISTENCY IN EXPRESSIONS OF INDIGENOUS IDENTITY}

\section{Hilary N. Weaver}

As I reflect on the topic of contemporary, emergent indigenous identities, I am flooded with a multitude of stories, most of them painful: the light-skinned, blue-eyed Native woman who presents her enrollment card to administrative staff in her own tribe when she goes to pick up her annuity yet is challenged about her authenticity and legitimacy; the Native man who uses his language fluency as a weapon to degrade and humiliate his Native wife who does not speak her own language; the youth who argue about whether it is possible to be both Native and American; and the respected, traditional elder who asks the venom-laden question, "are you Indian or are you Christian?" Contemporary indigenous identities are multifaceted and are shaped by societal pressures, internalised oppression, cultural pride, and a host of other factors.

While it would be an impossible and contentious task to reflect on all, or even most, aspects of contemporary indigenous identity, I accept the challenge and honour of being asked to share my perspectives. While in my academic life I have done research and writing related to identity issues, it is likely my own life experiences and reflections that primarily fuel this chapter. Of the many identities that I bring to this chapter, some of the most salient are that I am Lakota (by birth), Seneca beaver clan (by adoption), urban, of mixed heritage, a member of the Longhouse, and a mother. 
As I reflect on the topic of emergent identities I feel compelled to examine how the emergence of today is firmly grounded in the submergence of indigenous identities in the past. I also question how being Native American/Indian/Indigenous/First Nations has been defined (often in constricted ways that reflect oppression and internalised oppression) and how we might be able to emerge from these oppressive constraints. I examine how identity is reflected in names and appearances, and ultimately reflect on what this means for future generations. These are my thoughts, for what they are worth.

\section{Contemporary Emergence as Grounded in the Submergence of the Past}

Indigenous people of today have more freedom and ability to express their identities than Native people of the past few generations. In the United States, as in many other colonial societies, most expressions of our indigenous identity such as language, spirituality, and cultures were suppressed. Those who attempted to assert their identities were often severely punished. Native children who spoke their languages in boarding schools were beaten. Native people who asserted their spirituality faced legal repercussions. Native people who maintained their cultures, were taunted as backward and uncivilised. For the past century and more, it has often been difficult, and at times unsafe, to visibly and audibly embrace Indianness.

My grandfather was born in October, 1891, nine months after the infamous massacre at Wounded Knee in present day South Dakota. It was a difficult time to be Lakota. As the oldest of nine children, he suffered from malnutrition and rickets that would leave his legs twisted and bowed for the rest of his life. Poverty was a constant. In hindsight, I reflect on this time as a crossroads where indigenous people faced stark questions about their survival. Demographers tell 
us that our population numbers were at their lowest at the turn of that century. Was there a future for the Lakota people?

After attending boarding school, my grandfather developed a zeal for education. For him (and for my grandmother whom he met at boarding school) survival and assimilation were synonymous. In order to survive, indigenous identity must submerge. When he returned to his homeland (what became known as Rosebud reservation) in the 1930s, he did so in the guise of an American. Education and assimilation seemed (to him at least) the only options. As an employee of the Bureau of Indian Affairs, his indigenous identity was submerged under the rising tide of Americanism. Indeed, I am convinced that at that time he saw no safe alternative, as the slogan "the only good Indian is a dead Indian" continued to ring throughout the country.

In hindsight, as an alternative to a generation of "dead Indians" we now have a generation (or generations) of "submerged" Indians. In writing this chapter on emergent indigenous identities, I must respectfully acknowledge the submerged indigenous identities, those who did not have the freedom, safety, and/or privilege that those of my generation have to emerge.

\section{Stepping Out of the Box}

Ideas about Native American identity often seem relegated to a very small box. After all, we "know" what an Indian should look like, just as we know that Indians are spiritual, live in harmony with the earth, and have a tendency to be war-like. We seem to have a hard time moving beyond a very narrow set of stereotypes when it comes to thinking about indigenous identity. 
Perhaps we could benefit from examining how some scholars and activists have begun to think out of the box when it comes to gender. Rather than a dichotomous variable of male/female, they have encouraged us to think in terms of a spectrum of gender expression. Stepping outside the box, we are challenged with labels like "gender queer". Perhaps pushing beyond conventional definitions of gender provides a model for moving beyond static and stereotypical ideas about what is "Indian" and what is "traditional". How might breaking out of our own box reshape our thoughts about being indigenous? How might we reflect on questions of what it means to be traditional and who decides this?

To be clear, I do see great value in "traditional" beliefs and cultures of indigenous people. I think there are core aspects of our cultures that make us distinct. The very fact of being indigenous (i.e., people of the land) shapes our values, beliefs, and existence, as well as our legal status in ways quite distinct from members of colonial societies. However, I am concerned, dismayed, and angered when we internalise oppression to the point of saying that one way of being indigenous is superior or more authentic than another. In a mixture of internalised colonisation and feelings of inadequacy, it is common for some people to question the legitimacy of others' indigenous identities or "Indianness" as a way to define and assert their own (Carpenter 2005).

There is quite a list of ways in which some Native people don't live up to someone else's standard of being Indian enough. You are likely to be told that you are lacking, not good enough, not traditional, or not a real Indian if:

- You don't speak your language

- You don't live on a reservation

- You live away from your traditional territory

- You are of mixed heritage 
- You have successfully attained a college degree or beyond

In some cases you are also considered less than a real Indian if you are baptised or follow Christian beliefs rather than traditional indigenous spirituality.

Ideas about where someone lives and its relationship to their "Indianness" are of long standing. Even in the 1920s, a woman claiming an indigenous identity yet living in New York City came under scrutiny for her authenticity (Carpenter 2005). In spite of longstanding federal policies that encouraged Native people to leave their reservations and relocate to urban areas, there often remains a presumption that an indigenous person living on a reservation is more authentic than one living in a city.

In fact, there are a multitude of reasons why contemporary Native people present some or perhaps all of the above listed "non-Indian" traits. There are many of us, myself included, who "don't fit the mold" of what we are told an Indian is. We need to raise the question, "Who created a static, rigid mold anyway?" Was it "them"? Is it "us"? It is likely that static, stereotypical visions of indigenous identity are maintained both by outsiders and by insiders for a variety of reasons that space does not permit elaborating on in this chapter. Suffice it to say, it is not enough to claim that outsiders have limited our ideas about indigenous identity - we need to reflect on how our own beliefs, attitudes, and behaviors as indigenous people limit our understandings of how indigenous identity is and could be expressed.

\section{The Dichotomous World}

We often conceptualise the world in dichotomous terms that reflect who is an "us" and who is a "them"; who is indigenous and who is not. While the illusion of clarity can seem reassuring, it leaves no room for 
gray areas and keeps us confined to thinking in terms of the aforementioned box. People of multicultural and/or multiracial heritage have fought against being forced into either/or choices about their identity, insisting instead on asserting an additive or multiple identities. Their battles have been met with varying degrees of success. For example, while some forms now allow people to "check more than one box" to reflect their identity, they often still face attitudes of others that expect them to state which one they "really" identify with, or they are assumed to fit a particular identity based upon skin color, hair texture, or phenotype.

Some traditional teachings also encourage us to think in terms of static, inflexible models of indigenous identity. Among the Haudenosaunee (aka Iroquois Confederacy) ideas about indigenous identity are commemorated in the Two Row Wampum belt. When Europeans first came to North America in their ships hundreds of years ago, the indigenous people met to determine how they would respond to the newcomers. It was decided that the Europeans would be allowed to live and follow their own ways of life and traditions. Conversely, the indigenous people would continue to live independently and apart from the Europeans, following their own ways of life and traditions. Neither way of life was considered superior to the other; they were simply different. The Europeans had their ships and the Haudenosaunee had their canoes. If an indigenous person chose to live the lifestyle of the newcomers that choice would be respected. Likewise, a European who chose to leave behind his or her own ways and live with the Haudenosaunee and following their traditions, would be welcome. Either way was equally valid, but a choice had to be made.

The Two Row Wampum belt shows two parallel lines: the two types of boats. You do not stand with one foot in each boat. To do so is 
foolhardy and you will inevitably fall into the water. You must make a choice. While I do not mean to suggest that this is the only interpretation of the Two Row Wampum belt, it is one that is commonly used to define indigenous identity as separate and never intersecting with other ways of being. This becomes a virtually impossible mandate for contemporary indigenous people as we try to find our way in an increasingly global society.

I continue to fall in the water as I struggle to maintain traditional beliefs, practices, and spirituality while living in a multicultural urban environment and teaching at a major research university. While it continues to be an uphill battle, I try to balance attendance at ceremonies with teaching classes and attending faculty meetings. I give thanks and harvest medicinal plants on days when a stack of papers is waiting to be graded. I constantly feel guilty that I am not adequately fulfilling my obligations on either side. Such is the price for trying to keep my feet in separate boats.

As a contemporary indigenous person, I will not choose one boat over the other but I do get tired of having a face full of water and wonder if the day will come when I will drown. In the meantime I keep trying and looking for some sort of life vest or nose plugs to help with the constant bombardment of water. Perhaps there is some hope as offered by a Navajo scholar who suggests that living by Navajo values while being immersed within the larger dominant society can actually serve to reinforce and maintain an indigenous identity (Lee 2006, 81). Indeed, living in two worlds (or negotiating two boats) has been identified as a virtual necessity for contemporary Native Americans. This ability to balance was found to be one of four crucial elements for Ute women in tribal leadership positions (Barkdull 2009, 130). In many ways, the contemporary existence of indigenous people is defined by continuous struggles to span different ways of being. 


\section{What's in a Name?}

The ability to claim or bestow a name can be powerful and filled with meaning (Braun 2008). Names are typically bestowed on us by others. It is odd that this representation of "us" comes from elsewhere, yet we are expected to "wear" it as a symbol of ourselves throughout our lives. Sometimes names have an "ethnic" ring to them. A certain name may communicate whether someone is likely to be Muslim, African American, or Irish. Common societal images and expectations tell us that Indians are supposed to have colorful names, often reflecting animals or parts of nature. You know you must be talking to a "real Indian" when you are introduced to Rufus Small Bear or Mary Running Deer. Individuals with anglicised names are asked if they also have an "Indian name". Even t-shirts advertised in mainstream catalogues reflect this way of thinking as we are encouraged to buy shirts that say, "My Indian name is Runs with Beer".

In a societal context where names have become so laden with stereotypes, what does this mean for an indigenous person whose name appears to reflect and reinforce the stereotype that Native people have colorful names? What does it mean for the Native person whose name does not reflect stereotypical ideas of what a Native person should be called (i.e., Smith, Johnson)? Is authenticity as an indigenous person (or lack thereof) tied in with the name that we inherit or is bestowed upon us?

What of people who carry both a name used in day-to-day life and have an indigenous name that has been bestowed upon them in a ceremony? Are they more legitimate than their cousins who, for what ever reason, have not been given a ceremonial name? Who does and does not have a name provides significant fodder for internalised oppression and battles over "Indianness". 
In contemporary times when assertions of indigenous identity have become safer, there are some families, mine included, who return to indigenous names as assertions of identity and cultural pride. My son does not have an English name (as indeed he is not English). He does not have an "American" name; a reflection of my beliefs and priorities. I gave him the name Wanblee to proudly reflect our Lakota identity, although as a compromise I did choose the spelling that I believed Americans were least likely to mispronounce. He also carries a Longhouse name bestowed on him by the Beaver Clan in Mid-winter ceremonies when he was a few weeks old. As a parent I feel I have given him a solid grounding in his indigenous identity that will allow him to stand strong and emerge as a proud indigenous person.

Names, as I noted above, are typically given to us by others although they are presumed to represent us. My son received his names from me and his clan. I think they fit him but he wears them with discomfort, at least at this stage of his life. Periodically he asks why he can't have a "normal" name, as if I have saddled him with a burden to bear. (Have I?) As he blurted out a couple of years ago, "Why didn't you just name me Tommy?" While they may assert it differently than adults, Native youth clearly experience the challenges of being indigenous in contemporary society.

\section{The Power of Visual Images}

Ideas about indigenous identity are intimately intertwined with perceptions of what an Indian should look like. Long brown hair, often braided, and tan skin (not too light and certainly not too dark) are the hallmarks of the Hollywood Indian and what we have come to expect Native Americans to look like. Additionally, Indians are much more recognisable when wearing lots of turquoise jewelry and perhaps some feathers in their hair. Fringe also makes a nice addition. Lest we think that it is only old-time Hollywood movies that perpetuate 
stereotypical images of Native Americans, the currently popular Twilight (2008) series reminds us that stereotypes are alive and well (LeValdo-Gayton 2011).

These stereotypical ideas have some grounding in reality, or at least the reality of the past. Native Americans (at least presumably the authentic ones) are frozen figures from a distant and romantic past. Perhaps this is why there is often difficulty recognising contemporary indigenous people who dare to appear different. Native people also play a role in perpetuating stereotypical images. In particular, a study of how tribes represent themselves on their official websites found that tribes with an incentive to attract tourists to casino gambling were likely to represent their own identities using historic and exotic images (Cuilleier \& Ross 2007). Apparently, some tribal officials believe that it is lucrative to perpetuate stereotypical images of indigenous people as romantic figures locked in time. It seems ironic that images of Native people as "other", previously used as justification for land appropriation and genocide, are now reframed as a way to entice tourists.

\section{In a New Community, in a New Day}

Contemporary indigenous people find themselves with considerably more freedom to express their identities than those from recent past generations. We also face additional challenges as we try to determine what it means to be indigenous in a multicultural society. A sense of community and feelings of belonging are typically identified as central aspects of an indigenous identity (Kenyon \& Carter 2011). This being the case, what are the implications for indigenous people who live outside of their traditional communities or perhaps outside of any indigenous community (either geographically or socially)? What does this mean for those mentioned earlier in this chapter whose right to belong to an indigenous community is challenged based on their skin 
tone, eye color, political bent, religious affiliation, or a host of other attributes presumed to be associated with an authentic indigenous identity?

Some scholars argue that indigenous values and philosophies should be one of the key components for measuring an indigenous identity (Horse 2005, Lee 2006). While this standard may in some ways be an improvement over the essentially valueless measure of blood quantum commonly used for tribal membership, evaluating someone's values to determine if they are Indian enough leads us into yet another quagmire.

I, like many of my contemporaries, live in an urban environment, in a territory that traditionally belonged to another indigenous group. I try to put a positive and unconventional spin on assimilation as I learn the traditions of my adopted homeland. Living in Haudensaunee territory, I participate in the Seneca Longhouse and raise my children within these traditions and life-ways. For me, this type of assimilation means adding to - rather than supplanting - my Lakota identity. My children both have Seneca names (as do I).

Recently, we traveled to our traditional Lakota territory in the Great Plains where we visited the town of Wanblee, South Dakota. Both my children reveled in the experience but especially my son Wanblee who posed for many pictures in front of the town sign with his name on it. A particular favorite is the picture taken in front of the "Wanbleemart Hot Stuff" sign - an advertisement for pizza at the local convenience store. At least on that day it was good to have the name Wanblee and to be in a place where people recognised the name. Now questions arise why my first-born, Iris, has a Seneca Longhouse name but not a Lakota name. All in all, I suppose our names, location, and limited language abilities (with smatterings of Lakota, Seneca, and 
Mohawk) reflect the realities of being a contemporary indigenous family in a multicultural world.

Speaking for myself, I feel empowered to express an indigenous identity. As a child and teenager in the 1960s and 1970s I often wore my hair braided and in braid-wraps (after all it was the 1960s and 1970s). It was a time when the activism of the Red Power movement impacted my family's life in ways more implicit than explicit. It was acceptable to tell people I was Lakota although I grew up knowing more about the Nez Perce, Couer d'Alene, Spokane, and Yakama people that surrounded my Eastern Washington community than I did my own heritage.

In 1973 my grandfather died. My parents and I drove across the country with my newly widowed grandmother. As an 11 year old, I had only a limited understanding of the adult conversations as we drove through South Dakota and listened to the daily news about the siege at Wounded Knee. My mother talked about how we were Iyeska, mixed-blood people who often served as a bridge or peacemakers between cultures - a role that was much needed at that difficult time. My grandmother had not been back to South Dakota since she was taken away to boarding school as a child. She had buried her past and rarely spoke about it. Driving through South Dakota and later attending powwows with us in the Northwest for the first time in more than 50 years she felt safe enough to begin to whisper about the past that had been left so far behind.

Beginning in the 1980s, my mother spent considerable time living, working, and reconnecting in the Lakota villages spread throughout the Great Plains. The re-emergence that began with my grandmother's whispers was soon echoed with my mother's confident voice. Although my path has been different, this foundation supports me. 
The Lakota women in our family are no longer content to be submerged, yet I still struggle to fill many voids. I know only a few words of my language. I have been told (in what I experienced as a harsh manner) that it is impossible to be Lakota without being fluent in the language. I was raised in an Episcopal household, a by-product of extensive missionary work conducted over the last century or so. I strive to learn my traditional customs but I learn with the difficulty of an adult fully grounded in Western ways and traditions rather than the ease of a child born into a holistic, nurturing indigenous culture. Like many of my generation I will always feel a deficit in my knowledge of language and culture. I find myself feeling fiercely indigenous and struggling with multiple, on-going insecurities at the same time.

I am not alone in feeling a great void in not speaking my own language. This is a common source of pain for many people in my generation. Lee (2006) also spends time reflecting on whether it is possible for someone to be Navajo, yet not speak the Navajo language. Indeed, if language and identity go hand-in-hand, what of the growing number of people who identify as Navajo but don't speak their language? Who are they, if not Navajo? Not only is language loss painful for those of us who cannot speak our "Native" language, it is also difficult for Native speakers who find themselves increasingly isolated and lonely as fewer people are able to converse with them. Language loss is detrimental to the wellbeing of Native people (Lee 2006), but to effectively write-off or disregard those of us who are not fluent in our languages as non-Native, quickly becomes a genocidal and/or suicidal practice.

While I struggle to fill my vast learning inadequacies and deficits, I believe that the best thing that I can do is to pave the way for the future. My children, while still grounded in a multicultural society, 
have access to language and culture in ways that I never did. They are raised in the Seneca Longhouse and attend Lakota ceremonies as well, when possible. Each day they hear the Seneca words, ga noh kwa, "I love you," and their traditional names are used. They are exposed to many different indigenous cultures as well as other traditions. I give them tools that I hope will prepare them for their future.

\section{What do we want for our children?}

The question arises, "What do we want for our children?" For me the answer is an ability to express their ndigenous identities without the painful insecurities that permeate my life as an indigenous person raised in the wrong place without the nurturance of my own culture and language. I am, however, constantly aware that my answer is quite different from how my grandparents answered this question. For them, the best choices that they could make for their children were survival through education and assimilation.

My grandparents deliberately raised my mother and her brother without the Lakota language and away from other relatives, as these were seen as barriers to survival in American society. Extended family members led lives heavily immersed in alcohol and violence. For my grandparents, providing a better life for their children meant separation from community, culture, and language. Assimilation was the way of the future; that way the children would not have to shoulder the same burdens of extreme poverty, racism, alcoholism, and violence.

Like my grandparents, I want to protect my children from the burdens that I experience: those of feeling lost and never quite good enough. In the end, future generations will make their own choices (and may very well make very different decisions) about how they will express their indigenous identities than the plans that I make. 
I'm not sure how indigenous identities will be expressed by future generations. It is my hope that my children and those who come after will retain the safety to be indigenous that my generation has been privileged to experience. It is also my hope that they will be able to proceed without the insecurities and internalised oppression so commonly experienced in my generation. Rather than thinking of ourselves primarily as independent individuals, many Native American nations have a concept of being linked to ancestors of the past and descendants of the future through seven generations. The teachings of the Seven Generations tell us that we must constantly plan for the children of the future so that they will have the resources, both natural and cultural, to live their lives to the fullest just as our ancestors planned for our survival. While our responsibility is to preserve their options, we do not (and should not) have the ability to make their choices for them. Their indigenous identities will emerge according to a plan not of our making.

While the details of my children's future are beyond my knowledge, I am confident that Iris, born on the first day of the new millennium, will continue to blossom into the strong, beautiful flower that her name represents. She will determine for herself what it means to be an indigenous person in the $21^{\text {st }}$ century. Likewise, my son Wanblee will soar like the eagle that he is and will explore new horizons and new ways of being indigenous in a global society. He will be a leader in a new generation of indigenous people who are indeed "Hot Stuff."

\section{References}

Barkdull, C. 'Exploring intersections of identity with Native American women leaders.' Affilia: Journal of Women and Social Work 24, 2 (2009): 120-136. 
Braun, J. (2008). 'What's in a name? Tribal colleges cultivate students' cultural identity.' Tribal College Journal 19, 3 (2008): 14-19.

Carpenter, C. 'Detecting Indianness: Gertrude Bonnin's investigation of Native American identity.' Wicazo Sa Review 20, 1 (2005): 139-159.

Cuillier, D. \& Ross, S.D. 'Gambling with identity: Self-representation of American Indians on official tribal websites.' The Howard Journal of Communications 18 (2007): 197-219.

Horse, R. G. (2005). 'Native American Identity.' New Directions for Student Services 109 (2005): 61-68.

Kenyon, D.B. \& Carter, J.S. 'Ethnic Identity, Sense of Community, and Psychological Well-being Among Northern Plains American Indian Youth.' Journal of Community Psychology 39, 1 (2011): 1-9.

LeValdo-Gayton, R. 'Jacob as Tonto: Perpetuating Stereotypes that Further Marginalize Natives.' Journal of Mass Media Ethics 26, 3 (2011): 250-253.

Lee, L. 'Navajo Cultural Identity: What can the Navajo Nation Bring to the American Indian Identity Discussion Table?' Wicazo Sa Review 21, 2 (2006): 79-103. 


\section{IDENTITY POLITICS: WHO CAN COUNT AS INDIGENOUS?}

\section{NM Nakata}

When I sat down to finally write this article, a televised discussion program, Insight ${ }^{48}$, was running on SBS Australia on the topic of Aboriginal identity. ${ }^{49}$ The audience was almost entirely made up of Aboriginal Australians and the discussions revolved around some very predictable themes and positions:

- who can call themselves Aboriginal;

- what are the criteria of being Aboriginal;

- who has the right to judge and determine who is Aboriginal.

At the heart of this discussion were contentious identity issues largely associated with the ambiguities of people with mixed-heritage. These issues emerged around the primacy of colour and of 'looking recognisably Aboriginal', the significance of Aboriginal cultural values

\footnotetext{
${ }^{48}$ Insight is a national television program on the SBS chanel that caters for the more recent Australian migrants.

http://www.sbs.com.au/insight/episode/overview/490/Aboriginal-or-not ${ }^{49}$ In 2011, there were approximately 550,000 people identified as being of Aboriginal and/or Torres Strait Islander origin, as counted in the Census. This constitutes $2.5 \%$ of the Australian population. Within this Indigenous minority, Torres Strait Islanders are a distinct cultural sub-minority of $6 \%$. Of the approximately 52,000 Islanders, approximately 5000 still reside in the Torres Strait while the rest live in mainland Australia. Historical experiences and discourses of identity vary between these two groups within the common experience of colonisation. The term Indigenous is used in this paper as a shortened inclusive term when discussing issues common to both. http://www.abs.gov.au/ausstats/abs@.nsf/Latestproducts/2075.0Main\%20Features 32011 ? opendocument $\&$ tabname $=$ Summary \&prodno $=2075.0 \&$ issue $=2011 \&$ num $=$ \&view
} 
as an essential basis of Aboriginal identity, questions of whether an individual's life-experience included discrimination and racism, or being treated like an 'Aboriginal' by 'other' Australians, and questions around the links between Aboriginal identity, the distribution of resources, and the perceived relative need for resources.

All of these issues appeared to be anchored in concerns about the official processes required to confirm a person's Aboriginality, according to the official government/community agreed definition, in order to be eligible for positive discrimination measures. In Australia, the official definition includes three criteria, all of which must be satisfied. To be officially confirmed as an Indigenous Australian, an individual must be of Aboriginal or Torres Strait Islander descent, self-identify as such, and be recognised as such in the community in which he or she lives (Gardiner-Garden 2002). People requiring official confirmation must present their credentials to an incorporated Aboriginal or Torres Strait Islander body or organisation, and make their case through the presentations of genealogies and testimonies. If successful, they are presented with a confirmation letter stamped with the common seal of the organisation. This reminds me of the days when we, as Indigenous people, had to present ourselves to government administrators in order to receive our rations of flour, sugar and tobacco.

Those who spoke on the Insight program revealed some of the absurdities and injustices that result from the subjective and arbitrary practices when Aboriginal Australians seek official confirmation of their Aboriginality from Aboriginal organisations charged with that responsibility. These revelations quickly produced more questions that articulated a field of competing grievances and claims to a surviving and continuing Aboriginal identity: 
- Whose histories and experiences most reflected Aboriginal subjection under colonialism and ongoing racial discrimination, and who could still provide the detail and evidence of it?

-Whose historical and contemporary lives most reflected a commitment to maintaining distinct cultural identities, and

-Whose contemporary lives reflected an ongoing commitment to Aboriginal values and other Aboriginal people?

Over the course of the discussions throughout the program, the need to apply the three definitional criteria appeared to be upheld - descent and self-identification seemed to be generally accepted as an incomplete basis for claiming Aboriginal identity. And the downward spiral began. The necessity for some definitional criteria was supported by the implied argument that an individual's Aboriginal heritage needs to be embodied in some demonstrable and verifiable way in order to be officially recognised. Following that basis, the inference was that resources should go to those who had the best claims to being Aboriginal and the most in need of the resources. Then, of course, the priority of needs was contested; in one case, the needs of young children in communities were pitched against those of university students, and in turn whether academic scholarships for Indigenous higher education students could be considered as a need. The extension of identity arguments to a discussion of access to positive discrimination entitlements and/or resources implies that these sentiments also extend to Torres Strait Islanders and are issues for the Australian Indigenous community as a whole.

The discussion tonight on Insight would be familiar to indigenous people in other places as well. It parallels the historical analysis of fellow contributor to this edition, Bronwyn Carlson, and in particular to her doctoral thesis on The Politics of Identity: Who Counts as 
Aboriginal Today? (2011). However, in these ways of discussing and contesting the meaning of being Aboriginal or Indigenous, the 'identification' problem remains, and in the final determination centres on the third criteria of 'acceptance by the community in which one lives'. However, the question that many Indigenous Australians ask in private is: How can others, acting on behalf of a political and cultural collective, make judgement of an individual's claim to an Indigenous identity in the light of diverse Aboriginal historical experiences, the inter-generational mixing of heritages, and the contemporary social and geographical mobility of younger generations? Who is in a position to judge the historical journeys of all those of indigenous descent? In whose eyes, and on whose 'authority' can recognition be accorded fairly? The old relied-upon Indigenous ways of 'knowing each other' through older lines of knowledge and connectedness no longer work as well as they once did for many of us. Unless an individual possesses an acceptable historical narrative and/or works hard at building and maintaining an acceptable community profile, they stand to be assessed as inauthentic, accused of concocting a fraudulent act, and on both these counts, risk being rejected by the community (Carlson 2011).

\section{Questioning the Everyday Community Discourse of Indigenous Identity}

In an Indigenous population that is not just growing but growing younger, increasing numbers of Australian Indigenous families and individuals are becoming removed from direct experience of previous eras of oppression. They are also increasingly growing up in cities away from ancestral lands or the colonial collectives that formed around reserves and missions. These are two critical sources of cultural knowledge and historical experience required to build an officially acceptable identity narrative. As well, many of the victims 
and descendants of the Stolen Generations ${ }^{50}$ are reconnecting. It is not at all surprising then that the notion of community recognition as the basis for acceptance is fraught. Nor is it surprising, given the incomplete history of Aboriginal experiences of government policy, that some Aboriginal experiences and identities are more recognisable and acceptable than others, and some are more easily questioned, dismissed, or excluded than others. For my own group - Torres Strait Islanders - community recognition is a less contentious issue because of our different history. As long as an Islander family name can be retrieved, individuals can still be placed. In what is a small contemporary community, who historically were isolated on their own islands and kept apart from most other Australians as 'Reserves' until the 1960s, living memories are still strong. Nor is adherence to Islander custom stringently judged as an essential basis for identification as it often is in Aboriginal Australia. For Islanders, the emphasis is on family lines as a source of continued belonging and recognition. The passage of time, of course, may well intensify these issues in the Torres Strait Islander community in the way they now affect those Aboriginal people whose lives and kin networks have been disrupted for 230 years.

However, what is surprising, to me at least, is that although the processes for identity confirmation are questioned, the definition of Indigenous identity itself 'flies by us' relatively unquestioned along with the criteria for its determination. This was also found to be the case in Carlson's interview data (2011), and suggests that the contests over 'who is', 'what constitutes', and 'who should benefit from' claims

\footnotetext{
${ }^{50}$ The term Stolen Generations refers to those Indigenous Australians who were taken by White authorities from their mothers and families as children and placed in institutions and White foster or adoptive families (see Wilson, 1997). This occurred over generations as a matter of policy or practice until the 1970s. Many descendants now seek to reconnect and claim these stolen identities.
} 
to an indigenous identity are continually being reproduced through the restricted and embedded ways it is talked about in the broader community. Here I am not absolutely dismissing the need for a definition per se; while there is a political will or need to claim identified resources, whether from public, private or indigenous sources, there will always be official pressure for some form of 'identity check' in the interests of ticking off on transparency, fairness and accountability. And, where there is a will to survive as distinct people who have the longest claim to the land, there will need to be language enough to describe continuity and persistence of distinctiveness in contemporary and future contexts. Nevertheless, I do see a need to draw out the local and national 'community' position that subjects Indigenous individuals to political and moral judgements while authorising some Indigenous narratives of identity that silence and exclude others. This position also accepts that the historically recent pan-Indigenous identity, which has been self-consciously constructed and maintained on 'Indigenous terms', can be reduced to a definable, categorical, universally applicable 'narrative' of who 'we all are' or ought to be.

Compounding these emerging ways of talking and knowing each other is the added problem of a narrowing 'construct' of community itself, a concept that entered the popular discourse in the 1970s to enable the distribution of government funds and resources (PetersLittle 2000). The construct of 'community' as understood in contemporary terms is an inadequate substitute for traditional senses of social relatedness and communal orientations but seems to have been readily accepted by many who live in cities far away from communities as a legitimate equivalent, and a surrogate community. And so, I do question the easy community acceptance of the need for regimes of Indigenous identity confirmation that lead to internally oppressive practices. Such practices continue to diminish us, as they once did by government administrators, and abandon the efforts of 
our forbears who suffered and struggled for better treatment, and sought to be free of the confinements imposed by the so-called 'protection' regimes of early governments and missionaries. "We are in a closed box and wait for the lid to be taken off" (Torres Strait Islander to Deputy Chief Protector in Report 22 February 1936, 3). My objection to these emerging ways of "talking and knowing" who is Indigenous, however, leads me away from the logic that questions how individuals construct and express their Indigenous identities. It also directs me away from restricted narratives and judgements about what it means to be Indigenous. It leads me to think that the lines between debate about what it means to be Indigenous and judgements about whether an individual is Indigenous should be more consciously reflected on, and separated as we all converse and 'discourse' about it at the community level. But, my major concern with the community discourse is in regards to what the preoccupation with questions of collective and individual identity takes away from other critically important Indigenous agendas - namely agendas which impact on the material circumstances and future possibilities for Indigenous people, for example, how to raise the prosperity of all Indigenous people? What do we have to do now to start the process of eliminating poverty from our communities? How can we ensure all Indigenous people have access to the best available education? Where do we want our communities and people to be in fifty years vis-à-vis White occupation of our lands? How do we recover our ancient knowledge systems from White people's archives and reinstate their primacy in our lives?

\section{Particularising the Historical Roots of Contemporary Australian Indigenous Identity Discourse}

Clearly there is broad community understanding that Indigenous Australians' contemporary objectification of our own ways for naming 
and describing ourselves, and recognising each other is constructed in resistance to, and survival of, colonial objectifications of us (as a distinct homogenous social category of people who continue to be subjected to repeated injustices). However, in the way we contest what constitutes the markers of contemporary Indigenous identity at the community level, there are few concessions made to the effects of discursive positioning on our re-working of the colonial categories and the application of these re-worked understandings to ourselves. We understand why and what we define ourselves against, and in distinction from all other Australians and their historical and social assumptions about us. But, broadly speaking, at the community level it appears difficult to reveal and articulate how interpretations of the definitional criteria are discursively produced to effectively work in the interests of privileging some Indigenous historical experiences over others, or to recognise or privilege some Indigenous individual's heritage but not others.

In the way Indigenous identity is talked about, the lines of argument do not always recognise their own investments in different and intersecting discursive histories. In our construction of a panIndigenous identity, these investments draw to serve collective political goals and purposes, and in particular, goals or traditions of those local groups who are still traditionally anchored in their daily lives. And they draw to serve the reconstructions of the cultural knowledge of local groups whose traditions were severely disrupted by colonial activity (Tonkinson 1990). In the process, however, the lived subjectivities of the many thousands of Australian Indigenous families and individuals all over the country, sit in tension with these objectified forms. The lived subjectivities of Indigenous individuals have been, and continue to be, differently positioned in relation to historical oppression, continuing discrimination, access to cultural knowledge and continuity, degree of social advantage or disadvantage, 
generational impacts, gender, physical appearance, geographical location, and so on and so forth.

These diversified experiences suggest that there are particularities of Indigenous colonial and social experience that are not commonly shared by all Indigenous Australians. But, the Indigenous political struggle against the nation-state did give rise to a collective panIndigenous identity claim based on a shared cultural heritage and a shared history of oppression, as a way to transcend the multifarious group, family, or individually specific experiences within the broader history (Tonkinson 1990). The common community interpretation and application of the official definition assumes this shared experience but not so much as one with common outcomes across all Indigenous Australian people's experiences. There is a very strong awareness of differences across the pan-Indigenous community. Rather, the common community discourse assumes a united 'all in' commitment to an ongoing shared cultural and political orientation that depends on promoting and sustaining a unitary, essentialised, and imagined ongoing Indigenous subject as the building block of a socially and culturally cohesive, and politically 'solid' and impermeable collective (Rolls 2001).

Within everyday discourse, an individual may be as 'individual' as they like, as long as they publicly subscribe and demonstrate adherence to the 'community', 'political', and 'cultural' scripts and be 'seen' to participate in 'community' activity. For this, all Indigenous Australians must have a recognisable personal narrative and announce themselves publicly in particular ways (Carlson 2011). This practice does not support freedom or creative regeneration of a people with converging and increasingly complex histories, nor does it reflect the everyday reality of how people can or cannot conduct their lives. The tacit rules we have come to instate on each other have now become the 
authorising elements for the close regulation and surveillance of ourselves as individuals who now must live always under threat of public interrogation or exclusion. This all reeks of the colonialism we have strived for decades to rid our lives of. It suggests, to me at least, that in judging an individual's credentials for Indigenous identity claims, the current interpretive/regulative limits of the collective definition must expand to assume the presence of myriad ways in which the cultural heritage and history of oppression have manifested in different groups, families and individual's lives down the generations and through which it can be publically expressed.

However, and definitional issues aside, in the changing context of an increasingly expanding, urban, and 'mixing' Indigenous population, contests about identity are likely to continue, if not intensify as we saw on this SBS show tonight. Arguably, 'we' the Indigenous 'community' require more self-consciousness and self-examination of the way we talk about Indigenous identity rather than confining ourselves to endless contests over what is to constitute its legitimate markers. Here it is important for international readers to understand at least a little of the history of Indigenous identity production in Australia. Apart from being only $2.5 \%$ of the Australian population, the pattern of White 'settlement' and colonial disruption is relevant to contemporary constructions of Aboriginal identity. As Tonkinson (1999) points out, frontier expansion, which began in 1788, continued to the 1960s when the last of the Indigenous people from the Central Desert were brought in to live in a settled community. Although the particularities of hundreds of traditionally diverse groups were homogenised under the universal category of 'Aboriginal' by colonists from 1788, the uneven advance of the colonial frontier ensured that over time, groups, families, and individuals were experientially and socially differentiated. This was achieved through the different circumstances and experiences of the frontier, in different states and territories, 
which were followed by various and changing colonial policies and the variable, often capricious interpretations of those by different Europeans in different places and times (Rowley 1971). In the earlier and more densely settled parts of the country, dispossession, displacement and violence wreaked havoc on Indigenous groups. Ensuing government administration of so-called Aboriginal 'remnants' produced further dispersals, relocations, coalescence and re-organisation of groups of people. In the process, both differential losses and adaptations of cultural practices proceeded, and identities began to articulate not just around original kin networks but to mission and reserve experiences. Frontier and ongoing contact with Europeans ensured the mixing of 'races' across Australia, and in the first half of the twentieth century, government policies intensified a practice of assimilating fair-skinned, European-acculturating families or individuals into White society. The result was further disruption of Aboriginal kin and social relationships, as contact with extended Aboriginal families was made difficult, if not impossible. Further social-differentiation with regard to material and cultural circumstances also resulted. Along with the removal of fair-skinned children from darker Aboriginal mothers and families all over the country, in what has come to be known as the Stolen Generations, disconnection and dispersal of families was a widespread and farreaching practice over generations (Wilson 1997).

While this summary is far from a full account of historical contingencies, perhaps the most salient points of it for the contests that are evident in the contemporary community discourse are the historical policies and practices of assimilation. The long-term aim of Australian assimilation policies was the erasure of part-Aboriginal people. Full blood Aboriginal people were understood to be destined for extinction but part-Aboriginal people represented a threat to the purity of the European population in a country that pursued - and 
driven by the Labour Party from the outset - an assertive, coherent White Australia immigration policy from 1901 until 1972. In this context, part-Aboriginal people were labelled a 'problem' and deemed a 'transitional' category: people who must inevitably become White by adopting the European ethos, and over generations, the colour. It was not until the 1960s that governments conceded that 'full-blood' Aboriginal people would not die out and nor would 'part-Aboriginal' people discard their Aboriginal selves and disappear quietly into the White society (Rowley 1970, 1971).

With the rise of concerted Aboriginal political activism in the 1960s and 70s, and continuing through to the present, the rejection of assimilation was so profound that the concept of 'part-Aboriginality' was also categorically rejected (Coombs 1976). For the last four to five decades, we have come to adopt a very silly proposition that an individual is Aboriginal or an individual is not Aboriginal (e.g., Behrendt 1994). There is no in-between position with which to identify. All the terminology that represented colonial division of Aboriginal people from kin and each other - part Aboriginal, halfcaste, all the blood quantum measures and the more contemporary meaning of hybrid - are soundly rejected. This political move does not in any way overtly exclude those who are now not recognisably Aboriginal people in the physical sense, those whose continuity with cultural practices has been interrupted, or those who have been intergenerationally disconnected and seek to return. The repugnance for the historical division of families according to blood quantum militated against colour being used as a basis for determining identity (Anderson 1994, 1997). It also means there is a willingness to take those disconnected from their families back into the fold. However, as a result of historically imposed social divisions and the resultant cultural and kin discontinuities, inclusion into the Indigenous fold does entail conditions which produce the current predicament. 
From the 1960s, vocal appeals to a common pan-Indigenous identity have mobilised around ongoing political resistance to our containment within the nation-state. This standpoint does not just mobilise identity as a resource to secure State resources or social justice. It also mobilises around our continuing survival as a distinct people living almost invisibly amongst tens of millions of others. Thus, political assertion is also expressed through the urge for cultural renewal. This urge has placed the logic of dynamic or organic cultural change in a struggle with the logic of cultural essentialism, which is widely mobilised as a strategic political resource (Anderson 2003). However, while 'dual' or 'mixed' heritage is accepted, an individual's primary political and cultural identification must be demonstrably Indigenous.

The political move of the 1960s and 70s to instate simplistic either/or identity choices is increasingly being contested by some in terms of how it demands individuals to deny the fuller, more complex, personal lived expressions of all that they are (Holland 1996, Paradies 2006, Ganter 2008). Indigenous desire for a political pan-Indigenous solidarity, forged from a unity based on a shared cultural heritage and a shared history of oppression, becomes counter-productive and increasingly a site of resistance itself when mobilised to fix individual identities or to impose prescribed ways of enacting cultural and political commitments. It is here that an understanding of discursive positioning helps to reveal that the meanings of Indigeneity cannot be pinned down and fixed in advance of the discourses that produce them. To do so is to provide the conditions for both resistance and the ongoing social regulation of Indigenous bodies and Indigenous intellectual thought and speech (d'Cruz 2001, Langton 2003, Paradies 2006). An understanding of discursive positioning reveals how the attempt to pin down Indigenous identity in the collective sense in reaction to the 'positioning' nation-states produces as well our 
pernicious inter-personal readings of each other as individuals at the local community level.

\section{Expanding the Limits of Australian Indigenous Identity Discourse}

Contests around the objectified meaning of being Indigenous are likely to deepen over time where these depart from lived subjectivities. It is not easy at the community level to understand the discursive conditions of the objectification of Indigenous identities and the implications for those Indigenous subjectivities that do not fit this imagined reality. As someone who grew up as part of an Islander society, in a remote area of Australia, where we were the population 'majority' in the region, I was immersed in customary practice and had no self-consciousness about my identity in cultural terms. I was who I was, and although I recognised my difference from White people, being at home in my own world did not preclude an interest in knowing the outside world nor a desire for separation from it. This is not to say that all Islanders respond this way. I did have a more conscious political sense of myself as part of a long-controlled population still subject to diminishment and humiliation by 'White' authorities. Conversations about secession from Australia or the less radical pursuit of regional autonomy were part of the everyday yarning and yearning to be free of government control. When I moved to the Australian mainland to study, political ideology and the urge to mobilise our cultural accounts as a remedy for our social disadvantage did not sit well at all with my understanding and experience of our political and social struggles. The limits of these arguments glared out at me from the pages of texts and the voices of White liberals, Indigenous radicals, and Indigenous ultra-conformists. My attempts to speak back fell largely into a void and isolated me as some sort of 'bad' Islander who could not understand his own oppression and someone who did not suffer from cultural loss. I 
wasn't a 'bad' or 'good' Islander, I was merely thinking through my own experiences, capacities and interests in my critical engagements with academic propositions. The idea that my intellectual engagements should confirm and conform to either textual or community narratives was something at odds with my own selfunderstanding of life histories as I had experienced them.

In the twenty-four years since I commenced study, these frustrations about the narrow confines that frame Indigenous arguments in many social domains and discussion, have persisted. These narrow and narrowing ways reflect and are reflected in the 'community' discourses of identity. The way we conceptualise and police Indigenous identity in Australia produces its own disabling effects on the way we think and talk about a whole range of social issues. Quite apart from the exclusionary and silencing effects on Indigenous subjects, and apart from the deleterious effects of the political machinations at the community level, our constructs of Indigenous identity also ground a pervasive and pernicious logic that regulates 'who can speak' and 'what can be said or not said' about any Indigenous interest in any domain (d'Cruz 2001, Langton 2011). Those who speak beyond community discourses, as I often do, are often questioned on more than the logic, potential, or worth of their ideas or arguments. To dissent from the established Indigenous consensus is to invite the questioning of one's identity, especially if that identity is ambiguous on any other measure. For instance, while it is difficult to dispute my Australian Indigenous identity, they are not averse to questioning my loyalties to 'culture', 'community', 'the cause', and even at times accusing me of 'lacking spirituality'. That is, if you do not have community connections or not living 'your culture' in the community, you can't be accepted as Indigenous. This is a hard pill to swallow when the questions come from people who were not raised in a community rich with traditional languages and practices as I was. I 
remember these same propositions being expressed in the community long ago, but back then they were expressed by White administrators to divide the community.

It is one thing that the way we talk about Indigenous identity in Australia has come to be the way we talk about and judge each other; this is destructive enough at the personal and community level. But, the larger question is, how does this preoccupation translate at the broader level of social theory, policy and practice? Arguably, it obfuscates, distracts from, and ultimately defers the real work that needs to occur to provide the fullest set of opportunities for Indigenous people. More importantly, more of us should be questioning the tacit acceptance of our narrow assumptions about who we are, as scrutiny of their various deployments will become the first drivers of more constructive agendas. The current trend to position 'identity' as a central organising principle of Indigenous social policy, or frameworks for educational practice ${ }^{51}$ appears logical and has gone unquestioned. It is, however, only logical within its own discourse. If we cannot think what other organising principles might drive social innovations more effectively in Indigenous interests across a range of sectors, we merely illustrate how captive we have become to the discourse - how, for instance, we have almost completely abandoned our early political stance on colonists as squatters on our lands and who need to pay the rent.

To be fair, Indigenous academics and others do consider the effects of our discursive positioning. However, many of these explorations are limited to interrogation of colonial discourses and are largely directed

\footnotetext{
${ }^{51}$ See for instance the Australian Curriculum Assessment and Reporting Authority's Indigenous educational agenda in the proposed national curriculum at

http://www.australiancurriculum.edu.au/CrossCurriculumPriorities/Aboriginaland-Torres-Strait-Islander-histories-and-cultures
} 
to re-energise our positions against the State or against the dominance of Western concepts and practices (Dodson 1994, Boladeras 2002, Fredericks 2004). There is much less exploration and interrogation of Indigenous discourse and their effects, with some notable exceptions (e.g., Holland 1996, Langton 2003, 2011, Paradies 2006). This also leaves less explored and interrogated limits of our own logic, argumentation and practice in relation to the possible meanings of being Indigenous, and how those limits more insidiously limit wider explorations and ideas to consider the possible ways for Indigenous people to move forward as a collective. Not only are Indigenous individuals ordered and regulated according to these limits, so are the many different ways that individuals reflect, think, analyse, and theorise in and about their social worlds. Thinking that conforms to political and cultural ideologies is unlikely to get us out of the trenches we are so assiduously maintaining. These trenches are home to radically dumb and unadventurous thinking. Not being able to think outside our own favoured ways of thinking about identity is increasingly counterproductive to the Indigenous cause, as some are beginning to question (Sutton 2009). To extend the possibilities for improving Indigenous futures, we need to test and contest our own assumptions as much as those of the State or Western knowledge. And the narrow constructs of Indigenous identity and the practices that police it need more conscious reflection not just in the academic sense but also at the community level. The assumptions that underpin Indigenous community discourse on identity are social constructs forged as part of a larger political rebuttal of the propositions of the nation-state, and while culturally and historically informed, they are not sacred or non-negotiable areas, however much the community discourse might imply. 


\section{Conclusion}

The dilemma of who can count as Indigenous today emerges in the pernicious ways that it does at community levels because many quite genuinely and seriously believe that boundary policing of 'who is' and 'who isn't' Indigenous is fundamental to our futures as distinct people and to our capacity to achieve social justice. This view reflects a very narrow vision of our possible futures, based on an equally narrow understanding of the diversity of Indigenous people's colonial experience and its socially differentiating effects over generations. The concept of community recognition of Indigenous identity, and its interpretation as a criterion of Indigenous identity in Australia, needs serious questioning. It could perhaps be more easily allowed to fall away as an identity criterion if 'what any Indigenous individual says or thinks' in the public domain was assessed or contested on the logic and content of argument, rather than routinely tied to questions or assessments of their 'identity'.

Deeper engagement with the complexities that constitute our sense of ourselves must surely augment our sense of ourselves as survivors able to continue on, beyond other's representations of our primordial natures and beyond our history of traumatic oppression. Where this might lead cannot be foretold, but the possibilities to make and remake ourselves will still be present. None of this precludes continuing efforts to revitalise cultures and efforts to remember and tell our histories - these practices are not suppressible. But, nor should they restrict how individuals can act and think through their own specific histories, capacities and desires to build their own trajectories into the future or to contribute to Indigenous social commentary or theorising. 
The younger generations increasingly have access to and interests in the ways that global, national and local histories, contemporary realities, and envisioned futures all converge to shape the possibilities for thinking about what their claims to Indigeneity mean personally and how they might be negotiated in the public arena to uphold Indigenous interests beyond their own. Their conceptual work will be how to rethink and rework the interface between the fluidity and diversity of complex personal identities and the rigidity of the defined identity category of the Indigenous collective. In the meantime, the 'work' of the generation above them must include gathering together a larger picture of the Indigenous Australian's historical position, a larger picture of the diverse effects of colonial and ongoing experience on different individuals, families and groups, and a larger vision of future possibilities. If our ways of talking can encompass a larger and more complex picture, the possibilities for Indigenous identity recognition also enlarge to encompass the reality of Indigenous diversity in contemporary times.

In Australia, as it was presented on the television set tonight, the way the Indigenous community currently converses about identity makes it difficult for increasing numbers of Indigenous individuals to negotiate the tensions between their lived identities and those objectified constructions of Indigenous identity that have shaped both our consciousness and our discourse for the last forty to fifty years. If everyone must construct and tell their story to fit the discourse, to be heard, to be recognised, to justify their claim, not only once but day after day after day, here, there and everywhere, then what does the intercourse fail to capture about the reality of contemporary Indigenous identities? My current engagement with younger Indigenous university students signals to me that new and thoughtful ways of thinking and talking about Indigenous identity will emerge and eventually transform the current community consensus. It is my 
hope that these unhelpful deployments of a monolithic Indigenous 'community' will, though our own teaching, be explored by a more questioning younger generation.

\section{References}

Anderson, I. 'Black Bit, White Bit.' Republica 1 (1994): 113-22. Anderson, I. 'I, the Hybrid: Aborigine: Film and Representation.' Australian Aboriginal Studies 1 (1997): 4-14.

Behrendt, L. 'Aboriginal Urban Identity: Preserving the Spirit, Protecting the Traditional in Non-traditional Settings.' The Australian Feminist Law Journal 4 (1994): 55-61.

Boladeras, J. 'It's Easier to be Black if You're Black: Issues of Aboriginality for Fair-Complexioned Nyungar People.' Unpublished Masters Thesis, Curtin University of Technology, Australia, 2002.

Carlson, B. 'The Politics of Identity: Who Counts as Aboriginal Today?' Unpublished PhD Thesis, University of New South Wales, 2011.

Coombs, H.C. 'Aboriginal Australians 1967-1976.' Presented at the Sir Walter Murdoch Memorial Lecture, Murdoch University, 1976.

http://www.murdoch.edu.au/vco/secretariat/records/murdoc hlectures/MurdochLecture1976.pdf

D’Cruz, C. 'What Matter Who's Speaking?' Authenticity and Identity in Discourses of Aboriginality in Australia.' Jouvert: A Journal of Postcolonial Studies 5 no. 3 (2001). Accessed November 13 2012. http://english.chass.ncsu.edu/jouvert/v5i3/cdcr.htm

Dodson, M. 'The End in the Beginning: Re(de)finding Aboriginality.' In Blacklines: Contemporary Critical Writings by Indigenous 
Australians, edited by M. Grossman, 25-42. Carlton:

Melbourne University Press, 2003.

Fredericks, B. 'Urban identity' Eureka Street, December, 2004.

Ganter, R. 'Turning Aboriginal - Historical Bents.' Borderlands ejournal 7, no. 2 (2008): 1-19. Accessed November 132012. www.borderlands.net.au/vol7no2_2008/ganter_turning.pdf.

Gardiner-Garden, J. 2002-2003. Defining Aboriginality in Australia, Department of Parliamentary Library, Canberra, http://www.aph.gov.au/library/pubs/CIB/200203/03cib10.pdf

Holland, W. 'Mis/taken Identity."]' In The Teeth are Smiling: The Persistence of Racism in Multicultural Australia, edited by E. Vasta, \& S. Castles, 97-111. St. Leonards: Allen \& Unwin, 1996.

Langton, M. 'Aboriginal Art and Film: The Politics of Representation.' In Blacklines: Contemporary Critical Writings by Indigenous Australians, edited by M. Grossman, 109-124. Carlton: Melbourne University Press, 2003.

Langton, M. 'Anthropology, Politics and the Changing World of Aboriginal Australians'. Anthropological Forum 21, no. 1 (2011): 1-22.

Paradies, Y. C. 'Beyond Black and White: Essentialism, Hybridity and Indigeneity.' Journal of Sociology 42, no. 4 (2006): 355-367.

Peters-Little, F. 'The Community Game: Aboriginal Self-definition at the Local Level', Research discussion paper no. 10, Australian Institute of Aboriginal and Torres Strait Islander Studies, 2000.

http://www.aiatsis.gov.au/_data/assets/pdf_file/5579/DP10.p df

Rowley, C. D. The Destruction of Aboriginal Society: Aboriginal Policy and Practice Volume 1. Canberra: Australian National University Press, 1970. 
Rowley, C. D. Outcasts in White Australia: Aboriginal Policy and Practice Volume 2. Canberra: Australian National University Press, 1971.

Sutton, P. The Politics of Suffering: Indigenous Australia and the End of the Liberal Consensus. Carlton: Melbourne University Press, 2009.

Tonkinson, M. 'Is it in the Blood? Australian Aboriginal identity.' In Cultural Identity and Ethnicity in the Pacific, edited by J. Linekin and L. Poyer, 191-218. Honolulu: University of Hawaii Press, USA, 1990.

Tonkinson, R. 'The Pragmatics and Politics of Aboriginal Tradition and Identity in Australia.' Journal de la Sociétié des Océanistes 109, no. 2 (1999): 133-147.

Wilson, S. R. 'Bringing them Home.', Report of the National Inquiry into the Separation of Aboriginal and Torres Strait Islander Children from their Families, Human Rights and Equal Opportunity Commission, Canberra, 1997. 


\title{
THE 'NEW FRONTIER': EMERGENT INDIGENOUS IDENTITIES
}

\author{
AND SOCIAL MEDIA
}

\section{Bronwyn Carlson}

The rapid rise in the use of social media as a means of cultural and social interaction among Aboriginal people and groups is an intriguing development. It is a phenomenon that has not yet gained traction in academia, although interest is gaining momentum as it becomes apparent that the use of social media is becoming an everyday, typical activity. In one episode of Living Black (an Australian television show featuring stories of interest to Indigenous people) entitled “Cyber Wars" (April 19 $\left.{ }^{\text {th }}, 2010\right)$, several Aboriginal people commented on their Facebook use. Allan Clarke, one of the Aboriginal Facebook users featured, stated that, "It's an intrinsic part of our daily routine...." My recently completed doctoral research ${ }^{52}$ reveals that Aboriginal people are active participants on social media sites and in particular on Facebook. In the course of my study, I conducted a content analysis of open Facebook pages that are popular with Aboriginal users, and being an avid Facebook user myself, I was able to navigate through many open pages and explore the activities taking place. In terms of self-representation, the findings from my research reveal that Facebook is becoming a popular vehicle amongst Aboriginal people, to build, display, and perform Aboriginal identities (Lumby 2010). Many Aboriginal Facebook users treat this site as a key self-representational tool to communicate their Aboriginal identity to

\footnotetext{
${ }^{52}$ Carlson, B. 2011, 'The politics of identity: who counts as Aboriginal today?, Unpublished Doctoral Thesis, University of New South Wales, <http://handle.unsw.edu.au/1959.4/51509>
} 
other social media users in online communities (generally other Aboriginal people or Aboriginal groups).

In this chapter I will explore the complexities of identifying as Aboriginal at this particular juncture in Australia. I will weave between offline and online spaces, as it seems to me that these are not mutually exclusive. Aboriginal interaction online often mirrors or adheres to offline expectations and regulations -Aboriginal people do not stop being Aboriginal because they are online. In his study of Inuit identities online, Christensen found that the Inuit "are generally embedding offline life into cyberspace" and that "[t]he Internet is not necessarily a space to hide in, nor is it a space that mysteriously filters away the cultural identity of people" $(2003,23)$. I hope to contribute to the discussion about how some Aboriginal people engage with social media and I wish to demonstrate that Aboriginal use of social media is not a peculiarity but rather an everyday activity for many. Social media as a 'new frontier' is where Aboriginal people, like many others, are busy seeking new ways of representing and identifying ourselves to each other - and others - in a global amphitheater.

There is a significant amount of research that suggests that being online provides a disembodied space where subjects can shift and change, and be creative in terms of the identity they choose to display (Robins 2000, Bell and Kennedy 2000, McCormick and Leonard 2007). However, from my research and interactions on social media sites, it seems to me that Aboriginal people embody rather than disembody their identity and cultural engagements when interacting online on social media sites. Christensen (2003) also found this to be the case in his study of Inuits' use of websites. Online identities are the product of cultural practices by real social agents that, while not inhabiting the same spatio-temporal domain, are still very much subject to the same scrutiny and regulations as face-to-face 
interactions. And, in many instances, it is the case that Facebook communication translates into the domain of subjectivity outside of online contexts. For example, 'friends' on Facebook invite others to attend events. Also, many Aboriginal users post pictures of themselves and others attending events to demonstrate their involvement with specific activities. Facebook, unlike many other social networking sites, straddles both the online world and the everyday offline world, where in many cases 'friends' on Facebook are often friends or acquaintances offline (Cooper and Dzara 2010).

Mathew Gardiner Birnbaun's doctoral research found that initial impressions about identity are formed in seconds after viewing a profile and that Facebook profiles helped to form opinions about users and who they are offline $(2008,170-171)$. This is not to suggest that Aboriginal people do not engage in embellishment or creativity in the way they fashion their online profiles. I am sure that many do. Facebook provides an environment where personal identity can be tested and accepted and where connection between the individual (Aboriginal) identity and the collective (Aboriginal) identity can develop. My research has identified cases where Aboriginal Facebook users feel the need to overly 'Aboriginalise' their profile page so other Aboriginal people will 'see' them as Aboriginal, and instances where anxiety is expressed when profiles do not demonstrate Aboriginality at first glance (Lumby 2010). Facebook allows the potential for creative interaction that can be more challenging to maintain in offline communications. As I will demonstrate, this is not to suggest that questioning and accusations do not penetrate the site, or that the threat of 'real' bodies does not occur (Fraser and Dutta 2008). I am sure many Aboriginal people are using social media and social networking sites such as Facebook in a variety of ways that are not always about being identified as Aboriginal. However, I am interested in the circumstances where Aboriginal people want to be identified, or 
are openly expressing or displaying Aboriginality online. To be Aboriginal online then, requires recognition from other people, and specifically other Aboriginal people, much in the same way that offline identities demand recognition.

Online Aboriginal identities assume a level of performativity in the sense that Judith Butler applies this term: “...that reiterative power of discourse to produce the phenomena that it regulates and constrains" (Butler 1993, 2). Like other modes of subjectivity, online identity for Aboriginal subjects acquires reality through the surveillance that, in Butler's words, regulates and constrains it. My research shows that in relation to identity creation, it is not just a matter of 'being' Aboriginal in an online site, but rather, Aboriginality must be 'done'. In other words, the performance of Aboriginality is necessary for the subject position to be taken seriously, and for recognition to occur in a meaningful way or a way that is likely to inscribe the subject's cultural identity as publicly recognised and affirmed. Indeed, the performative dimension of online identity for Aboriginal people is crucial. Performativity is an ongoing act of the 'casting' of self that requires "cultural capital" and access to the constitutive discursive elements of Aboriginality in order for recognition to be effective (Papacharissi 2011). These include, but are not limited to: knowledge of particular types of language, membership in organisations, participation in certain causes, the sending and receipt of recognisable Indigenous iconography, imagery, the posting of political statements, and the knowledge of particular community organisations, structures and practices. Political causes can include issues found on Facebook such as, "Stop the NT intervention", "Indigenous health inequality in 25 years", "Say stop to racism", and "Stolen Generation-Bringing them back home". In addition, users can add images, such as Aboriginal flags and icons demonstrating affiliation. Iconography is attached to a 
profile under headings such as "Koori Pride" and "Nunga Pride" 53 . An icon can be sent as a 'gift' to a 'friend' that declares or confirms identity, or denotes a particular affiliation with an interest group. The receipt of such a 'gift' can constitute the giver's acknowledgment of a user's Aboriginality. Music is another way to demonstrate Aboriginal identity. For example, links to the currently popular profile page of acclaimed Aboriginal musicians, Geoffrey Gurrumul Yunupingu and Archie Roach testify to an interest in Aboriginal music and musicians. When a user joins a network, the network is displayed on their page, and their profile is displayed on the network page. So if a user joined Archie Roach's page, their profile would be displayed on that page. Anyone visiting the page would see who were members or 'friends'. The more 'friends' and networks one adds or joins, the bigger and more visible the profile. My study revealed that 'doing' Aboriginality on Facebook requires ongoing attention and effort to maintain public recognition and to ensure the endorsement of Aboriginal status. 'Doing' Aboriginality is a work-in-progress for many, as "the curtain never comes down on the ritual of identity fabrication and selfexhibition" (Fraser and Dutta 2008, 40). It can be time-consuming and with the capacity to attract both acknowledgement and repudiation; "Rewards for fame and punishments for shame are sometimes distributed in unexpected ways... "know thyself becomes 'show thyself" (ibid.).

In contemporary Australia, Aboriginal identity is not a straightforward affair. There is much debate circulating in both academic and community spaces (both online and offline) about who counts or should count as Aboriginal and, who could or should

\footnotetext{
53 'Koori' and 'Nunga' are terms used by Aboriginal people to refer to themselves and have geographical relevance. 'Koori' refers to Aboriginal people from New South Wales and Victoria and 'Nunga' refers to Aboriginal people from South Australia.
} 
confirm such claims (Noble, 1996; Oxenham et al. 1999; Huggins, 2003; Paradies, 2006; Lamb, 2007; Heiss, 2007; Bond, 2007; Ganter, 2008; Gorringe et al. 2011; Carlson 2011). The following two examples illustrate the current concerns by some Aboriginal people about who counts as Aboriginal. The Australian Institute of Aboriginal and Torres Strait Islander Studies (AIATSIS) facilitated two workshops one in 2009 and one in 2011. The outcomes from both workshops contributed to the 2011 publication titled, 'Will the real Aborigines please stand up: Strategies for breaking stereotypes and changing the conversation' (Gorringe et al. 2011). The workshops sought the input of Aboriginal people, in various locations, answering the question of who or what should count as Aboriginal. Similarly, the NSW Aboriginal Education Consultative Group (AECG), after becoming "increasingly concerned about the increased level of community concern regarding issues of Aboriginal identity" $(2011,9)$, published their report based on community consultations in 2011, titled, 'Aboriginality and Identity: Perspectives, Practices and Policies'. The report states that, "[T]he issue of Aboriginality and identity is one of the most critical issues in contemporary Aboriginal affairs..." and notes the "growing community concern and uncertainty about who is and who is not Aboriginal and how Aboriginality is defined and determined..." (AECG 2011, 5). In its report, the AECG recommended that the current definition of Aboriginality, as defined by the NSW Aboriginal Land Rights Act (1983), be supported. The Act states that, "An Aboriginal person means a person who: a) is a member of the Aboriginal Race of Australia, and b) identifies as an Aboriginal person, and c) is accepted by the Aboriginal community as an Aboriginal person" (ibid.).

This three-part assessment was introduced by the government in the late 1970s as a means to identify Aboriginal people for the purposes of administering resources and funding. However, it is quickly becoming 
a process that Aboriginal people require of each other to confirm their Aboriginal status. Proof of the last condition requires a supporting letter from an Aboriginal council or organisation. Formal Confirmation of Aboriginality is important to have in order to apply for scholarships, to work in identified positions, and to access services designed specifically for Aboriginal people. It is not a trivial or sentimental document; it is a quasi-legal document, which can be and is used to evidence claims of Aboriginality. The three-pronged definition however, does not always fit the multitude of experiences, relocations and policy prescriptions that Aboriginal people have had to face under colonial conditions (Carlson 2011). While most who seek a formal Confirmation of Aboriginality document already identify and, know or have traced their family lineages, the issue of being recognised and accepted 'by the community in which he/she lives' can provide a stumbling block given the diasporas position of many Aboriginal people. It should also be noted that possessing a Confirmation of Aboriginality document does not always shield the possessor from accusations of not being Aboriginal. Nobody is exempt from being questioned, as Anita Heiss explains: "[i]n our own Aboriginal community, comments in discussions around who is and who is not Aboriginal can range from "They're not black enough" to accusing individuals of being "Johnny-come-lately's" $(2007,51)$. Heiss also notes that " $[c]$ riticism of Aboriginal people by Aboriginal people is strong, and no one escapes" $(2007,53)$.

Given that the Aboriginal community is tasked with confirming claims of Aboriginality, one would assume that there is a consensus on what constitutes 'the community'. However, this is not the case. The notion of Aboriginal community is complex. Peters-Little suggests that government policies and community organisations have been largely 'shaping 'who' and 'what' constitutes an Aboriginal community" (2001, 198). While throughout colonial history new 
Aboriginal communities emerged through enforced relocation and dislocation from ancestral country, the axiom the Aboriginal community' has only become entrenched in popular discourse since the 1970s to streamline government funding to Aboriginal people. Since the introduction of the term "community" into the public lexicon, Aboriginal organisations have taken charge of the meaning of the term, particularly in urban settings where it has specific connotations of official 'authority' at local levels (see Yamanouchi 2007, 2010). Furthermore, 'community participation' is recognised by participation in events hosted by Aboriginal organisations and by attendance at meetings (Yamanouchi 2007, 140). Conversely, "[i]t is within organisations' activities and events that people have their strongest sense of being part of an experience they call community" (2007, 144). Yuriko Yamanouchi's participants from southwest Sydney also reported that Aboriginal people who do not participate in organisations" activities "do not have much to do with the community" (ibid.). The inference is that community organisations are community.

Many questions emerge at these discursive boundaries as to what constitutes 'community', and therefore who can speak for, or confirm, an individual's identity (Lamb 2007). In the recent Weekend Australian Magazine (March 24-25, 2012), an article titled "Not so Black and White" details Aboriginal man Dallas Scott's experience of applying for a Confirmation of Aboriginality certificate, and his subsequent denial of one (Overington 2012, 15). Scott states that he has identified himself as Aboriginal all his life but when he wanted to access a service specifically designated for Aboriginal people, he was asked to provide proof of his identity. Scott was shocked by the rejection of his application for a Confirmation of Aboriginality document claiming, "Every time I walk out the door I'm Aboriginal, and suddenly I'm not" $(2012,15)$. Scott then logged into Facebook 
and updated his status, "Dallas Scott...is apparently not Aboriginal after all" (ibid.). Scott turned to the online community to air his discontent and this led to further discussion with his online 'friends' about his status as Aboriginal. Scott's actions lead me to wonder if he felt that he was part of an online community: a place where everyday issues can be blogged about, where opinions can be expressed and support rallied. I also wondered if Facebook provided Scott with an online community where his Aboriginal identity was accepted perhaps without question.

Many questions arise where answers evade me. Do online social networking sites reinforce and intensify current conceptualisations of Aboriginal identity or community? Or, is it that online spaces fracture old and broker new forms, or do new forms solidify around more varied and dispersed sets of shared interests? What of the continuum or connection between online and offline activity? What happens if an Aboriginal identity is rejected offline yet accepted online - do one's 'friends' become the locus to confirm and authenticate Aboriginality? Can social networking sites have the potential to act as verifiers of Aboriginal identity, or is that too 'out there' for us to consider? Facebook is arguably an example of an online community and is described by Acquisti and Gross $(2006,38)$ as an "internet community where individuals interact, often through profiles that (re)present their public persona (and their networks of connections) to others". On Facebook, members create their own profile page, and links to other profiles by joining groups, adding friends or 'liking' other pages (such as movies, music, political causes etc.). The pages that a user 'likes' are then displayed for others to view or post comments about. Users have the ability to post status updates to let 'friends' know what they are thinking or feeling at any given time just as Scott did in the above example. The ultimate purpose of having a Facebook page is 
that others will view a user's page, 'like' what they like and interact by commenting on activity.

Facebook 'friends' may be known in offline contexts, or are people connected online through known or unknown networks. Most Facebook users tend to 'friend' others who are similar in terms of identity, interests and networks. According to Di Micco and Millen's (2007) study of "multiple presentations of self in Facebook", most users were aware of how they represented themselves and did so with the intention of establishing a particular view of themselves. The study found that users represented themselves to fit with specific networks or communities $(2007,383)$. Facebook, though a communication tool, also functions to create and (re)present to others a public identity, and to attract similar profiles as part of a broader network or community (Lumby 2010). The core functionality of Facebook is that users have the ability to connect with others ('friends') and form or belong to groups that are similar or have similar interests, just as one would do offline. The idea is to increase one's 'friends' list, which then acts as corroborating evidence of a user's networks. If authenticating Aboriginality requires community recognition, does the online community count in this endorsement? If so, then the Facebook function of 'friends' would play a critical role in this endorsement of status and therefore the number of 'friends' listed would be just as important as the profile of the 'friends'. That is, one would need Aboriginal 'friends'.

I was afforded an opportunity to test the proposition that online communities such as Facebook may have, now or in the future, some role in authenticating or recognising claims of Aboriginality. At a recent conference where I presented research on social networking sites, an Aboriginal woman asked if I would join a Facebook site dedicated to Aboriginal and Torres Strait Islander scholars. The site is 
ostensibly for selected Indigenous people to discuss Indigenous topics of interest. Membership demanded confirmation of my Aboriginality by two existing members. I was accepted and was asked to pose a question for the group to encourage discussion. In line with my research interests, I posted, "Can community recognition of someone's Aboriginality come from an online community?" One respondent stated, "Community Recognition is just that!!!" implying that there is only one form of 'community' - and that is offline. I responded that my question had emerged in the course of my research and was not a personal assertion but intended as an idea for consideration and discussion. Responses immediately shifted from my posed question to vitriolic demands for my authentication - in particular for documented evidence of my Aboriginality. I responded that I did have a Confirmation of Aboriginality. I was then asked for further corroboration: was I a member of an Aboriginal Lands Council? I replied affirmatively. Another respondent claimed I was "NOT Aboriginal" and made mention of knowing my workplace and where they could find me. Finally, I was informed I would be removed from the group as my identity was under question. The response was followed by, "[A]nd for the record community recognition in cyberspace please, nothing can replace the real thing". This experience solidified for me that there is indeed a continuum between offline and online activity in terms of identity recognition or indeed, the refusal of recognition. The boundaries of who or what can count as Aboriginal are guarded well in both online and offline spaces. So, regardless of the assertion that 'the community' existed only in an offline context, my Aboriginality was denounced in this online space and I was reminded that this would have offline ramifications, as it was known where I could be located.

Self-surveillance and the surveillance of others is an everyday part of engaging with Facebook. Indeed, this is but a microcosm of the 
Internet's potential as a modern phenomenon increasingly driven by the desire of users to watch, monitor, scrutinise and emulate. Facebook users can never be certain if they are being monitored or not at any given time. In fact, it is expected that 'friends' will visit user profiles to read thoughts, conversations, likes, dislikes, and evaluate representations of a user's identity. Users typically don't want to betray social or cultural norms so, to some extent, they fashion their profiles so as not to wander from what might be expected (Subramanian 2010). For instance, if a user wanted to ensure that their Aboriginality was known and accepted they would not make statements that conflict with those expressed by the majority of members: to be part of a group often demands complicity to the group's professed belief system. A lesson which I learned myself online. Online surveillance, or "dataveillance", according to Michael Zimmer (2008, 79), "Encompasses a diverse range of activities and processes concerned with scrutinizing people, their actions, and the spaces they inhabit”. This calls to mind Foucault's (1995) analysis of Jeremy Bentham's model penitentiary, the Panopticon. Bentham's panopticon prison was designed to function as a round the clock surveillance machine that had the capability to oversee all prison activity at all times. The idea, simply put, was that the prisoner knew of the possibility for continual surveillance and therefore internalised this practice to reproduce a practice of constant self-surveillance. As Foucault states, "surveillance is permanent in its effects, even if it is discontinuous in its actions" (Foucault 1995, 201). On Facebook, one should assume that others might be watching. The censoring of identity takes many forms, but central to surveillance and selfsurveillance is the fear of being publicly dis-authenticated. It is this fear that regulates behaviour.

Despite my experience of expulsion, I am fascinated by the potential that social media may offer Aboriginal people. The rapid advances in 
mobile technologies and the uptake of these by Aboriginal youth in particular, can be seen in many communities (see, Kral 2011). I do not want to suggest there is no digital divide; rather, I want to counter any assumptions that Aboriginal people may have little interest in the possibilities of technology and the online environment. It is also apparent that such use is not limited to Aboriginal people living in urban settings. Kral's $(2011,5)$ research into how Aboriginal youth in remote Australia utilise digital technologies and social media revealed the popularity of Facebook as a platform to "upload their multimedia productions, comment on each others' mobile phone 'pics' and announce the immediacy of their activities with online chat". Interestingly, Kral also reports "they are also using these channels to air their thoughts and the cultural activities and concerns of their community" (2011, 5). Similarly, the recent publication, Our Place: People working with technology in remote communities ${ }^{54}$ (Nadarajah 2011) highlighted the use of Facebook by residents from the remote community Ti Tree in Central Australia. The story features April Campbell, an Anmatyerre woman, who actively uses Facebook not only to keep in contact with friends and relatives, but also to post news and information about her projects. Aboriginal people from all over Australia are connecting with April via Facebook where various language speakers interact and network with her online (2011). The notion of local in terms of community can be seen to be shifting. Now, in the online context, local can mean national or even global.

A friend of mine shared a story with me about his experience with Facebook. My friend managed an Aboriginal health service in a remote community and he had difficulty reaching many of the members of the community to let them know about health promotion

\footnotetext{
${ }^{54}$ Our Place: People working with technology in remote communities, issue number 39, May 2011, available at, http://www.icat.org.au/default.asp?action=article $\& I D=3$
} 
activities. One morning a staff member did not show for work and another mentioned that they had a late night so would probably not come it. My friend asked if the person had telephoned and was told that this information had been deduced from the staff member's Facebook profile. My friend was a little surprised to hear that the staff members, who were aged in their 50s, were Facebook users. When he commented to the staff member that he hadn't realised she was on Facebook, she replied, "We are all on Facebook". He told me that he then established a Facebook page dedicated to the health service and many of the community members 'liked' the page and he was then able to reach a larger number of community members than he had previously been able to.

On a personal note, I am one of four born to my mother who raised me. My father has ten children of which I am one. So, outside my immediate siblings I have six others who I was not raised with. As adults we have all found each other on Facebook. On Facebook, all of our children have come to know each other as well. My uncle, who I have not seen since I was a small child, has also found us on the site. In this online space, temporality and spatiality have been traversed and our family has grown exponentially. The potential for rekindling kinship on Facebook is worthy of further thought particularly in the wake of colonialism that has seen many Aboriginal families torn apart. One result is that some Aboriginal people have limited or no knowledge of where they would or should be connected genealogically. Facebook offers mechanisms that map and record place in ways that prior technologies have not. It places the user within a matrix of social connections that act as documented evidence to claims of kinship, country and local recognition. This element of Facebook has enormous consequences for Aboriginal people for whom, prior to this technology, identity was a matter of continual anxiety as there was often no public reference point for 
authentication. Facebook, while also presenting its own regulating force, has the potential for recognition as a valid online public record of self-assessment, self-representation and self-validation. Facebook is a site where connections with Aboriginal people function not merely as an artifice of online technology, but as real, lived stories that are recorded and shared and that can act as written testimonials to personal histories.

Though here I highlight Aboriginal people's active engagement with social media, I am aware that a contradictory argument can be made. The use of social media may well lead to many changes or different ways of understanding social and cultural interactions and maybe even to the way Aboriginal communities are conceptualised. Aboriginal people are diverse and have different opinions and experiences. It is therefore the case that there is no universal consensus on the issue of identity and culture in relation to social media. There are those who will assert that modern technology does not 'fit' with what they see as cultural practice. This view of course tends to deny Aboriginal people's use of technology, imposed and otherwise, for millennia. There are also those who guard the offline community boundaries and feel less able to identify the boundaries online; fear of the unknown terrain could induce rejection of the possibility for an online Aboriginal community and would reject the notion that the online community could or should count especially in terms of recognising Aboriginality. There are many who have only recently found out that they are of Aboriginal heritage. Given Australia's colonial history, this is not uncommon. Will Facebook and online communities offer the newly identifying a safe place to test the water?

My doctoral research indicated that Facebook might provide an avenue where newly identifying Aboriginal people can interact and 
join Aboriginal groups and develop confidence in claiming their identity both in online and offline spaces. On Facebook, users can grow networks, add Aboriginal 'friends' and learn from others. I am not suggesting that Facebook would offer safety from scrutiny - clearly my own example illustrates surveillance is practiced online - but Facebook does provide a certain distance where one can have time to respond (which is often not afforded in face-to-face interactions). As Christopher Pullen suggests of social media, "The potential to connect to diverse individuals in the formation of community offers both the affirmation of identity and opportunities to test out concepts or imaginations of self' $(2010,7)$. Facebook provides a platform for the exploration of Aboriginal identity, the observation of others' Aboriginality, and the discursive act of re-presenting identity where this is ambiguous, fraught or unknown. It is here in the online space that subjects can consciously shape themselves to meet the expectations of other Aboriginal people who may be looking. As evidenced in the Manago et al study, users of social networking sites "construct a sense of self in relation to what their peers are doing, gauging their progression in comparison to others" $(2008,452)$. This study reports that users spend time observing other people's profiles comparing themselves with "idealized images" (2008, p. 452). This self-surveillance technique means that "[p]ossible selves may be transformed into actual selves" (2008, 454) particularly if public approval is accorded. My research on this topic suggests a rich site for future inquiry around the meanings, construction, negotiation, expressions and confirmation of Aboriginal identity in Australia. It is interesting to consider what Aboriginal activity in the online environment means for the future notion of the 'Aboriginal community' and if the online community has any capacity to be recognised as an authenticating body for the recognition of Aboriginality. Will we reach a point in the future where we will hear Aboriginal people's claim to Aboriginality being declined because they 
are not known on Facebook? Or indeed, will we reach a point where authentication can become an online set of practices, administered and authorised by Aboriginal people?

Earlier this year an article appeared in the Herald Sun, with the headline, 'Indigenous leaders want to ban or censor social media including Facebook'55. In this case some Aboriginal people living in a remote location were calling for a ban on Facebook and social networking, as it was believed that it was fueling community tensions and what is referred to as "old family rivalry and blood feuds". In this community, what took place on Facebook also took place offline. It is reported that a street brawl occurred after exchanges on social media sites reignited a long-standing feud. So while some in this community were calling for a ban of social media, others were against censorship and were calling for more education in order that the community could have a better understanding of the capacity of social media ${ }^{56}$. What can be gleaned from Aboriginal use of social media, in my mind, is that Aboriginal social network users do not necessarily take on an online identity that is somehow dislocated or removed from their offline identity. That is, those who identify as Aboriginal offline tend to also identify as Aboriginal online. This seems to point to a divergence from the ways that many non-Aboriginal people use Facebook as a site where identities can be fabricated as a matter of

\footnotetext{
55 The Herald Sun, 'Indigenous leaders want to ban or censor social media including Facebook', available at, <http://www.heraldsun.com.au/news/morenews/indigenous-leaders-want-to-ban-or-censor-social-media-includingfacebook/story-fn7x8me2-1226237794483>

${ }^{56}$ It should be noted that online/offline community violence is not an Aboriginal issue, but a phenomenon across all communities, as can be seen by the use of social media in riots such as those in London. See a call to block social media in instances of riots, <http://www.smh.com.au/technology/technologynews/london-riot-social-media-blocks-totalitarian-20110812-1iq0o.html>
} 
choice rather than being a cultural affirmation. Aboriginal people, according to my research, actively use social media and are interested in what this might mean for us in terms of our cultural practices. This is borne out by the Australian Institute of Aboriginal and Torres Strait Islander Studies (AIATIS), which hosted a conference entitled 'Information Technologies and Indigenous Communities' on July $13^{\text {th }}-15^{\text {th }} 2010$. Among the topics discussed was 'Facebook and Social Networking. ${ }^{57}$ The session description claimed that sites such as Facebook "are going to be a critical part of life in your community in the future. New technology allows the creation of new linkages that have not been seen in our cultures before" $(2010,30)$. Clearly, the use of social networking is being discussed in scholarly and other contexts among Aboriginal communities and organisations, both offline and online. We still have a lot to learn about Aboriginal use of social media and the potential that social media may offer in terms of social and cultural interaction. But one thing is quite clear-social media is here, Aboriginal people are online and are posting and interacting with one another, having conversations, debates and forming relationships. Social media is a social site but as I have demonstrated, it is also a political site where Aboriginal struggles and identities are being played out in the 'new frontier'.

\section{References}

Aboriginal Education Consultative Group. 'Aboriginality and identity: perspectives, practices and policies.' Produced by Bob

\footnotetext{
${ }^{57}$ Information about The Australian Institute of Aboriginal and Torres Strait Islander Studies conference titled 'Information Technologies and Indigenous Communities' 2010 can be accessed at, <http://www.aiatsis.gov.au/research/symposia/Digi10/theme.html>
} 
Morgan Consultancy, 2011.

http://www.nrsdc.org.au/images/newsletter/Aboriginality_an

d_Identity_Report_November_2011.pdf

Acquisti, A. and R. Gross. 'Imagined communities: awareness, information sharing, and privacy on Facebook.' A paper presented at the Privacy Enhancing Technology workshop, Robinson College, Cambridge, June 28-30, 2006.

Bell, D and B. M. Kennedy, eds. The Cybercultures Reader. London: Routledge, 2000.

Bond, C. 'When you're black, they look at you harder: Narrating Aboriginality within public health', Unpublished Doctoral Thesis, University of Queensland, 2007.

Butler, J. Bodies That Matter: On the Discursive Limits of "Sex". New York: Routledge, 1993.

Carlson, B. 'The politics of identity: who counts as Aboriginal today?' Unpublished Doctoral Thesis, University of New South Wales, 2011.

Christensen, N. Inuit in Cyberspace: Embedding Offline Identities Online. Copenhagen:

Museum Tusculanum Press, 2003.

Cooper, M and K. Dzara. "The Facebook Revolution: LGBT Identity and

Activism.” In LGBT Identity and Online New Media, edited by C. Pullen and M. Cooper, 100-112. New York: Routledge, 2010.

DiMicco, J.M. and Millen, D.R. 'Identity Management: Multiple Presentations of Self in Facebook.' Proceedings of the 2007 International Association for Computing Machinery Conference on Supporting Group Work, Florida, November 4-7, 2007: 383-386. 
Foucault, M. Discipline and Punish; The Birth of the Prison. New York: Vintage, 1995.

Fraser, M. and S. Dutta. Throwing Sheep in the Boardroom: How Online Social Networking Will Transform Your Life, Work and World. West Sussex: John Wiley \& Sons, 2008.

Ganter, R. 'Turning Aboriginal - Historical Bents.' Borderlands ejournal 7, no. 2 (2008): 1-19. Accessed May 132010.

http://www.borderlands.net.au/vol7no2_2008/ganter_turning .pdf

Gardner Birnbaum, M. 'Taking Goffman on a Tour of Facebook: College Students and the Presentation of Self in a Mediated Digital Environment.' Unpublished Doctoral Thesis, University of Arizona, 2008.

Gorringe, S., Ross, J. \& Forde, C. 'Will the real Aborigines please stand up': Strategies for breaking the stereotypes and changing the conversation.' Australian Institute of Aboriginal and Torres Strait Islander Studies, Discussion paper 28, 2011.

Heiss, A. 'Writing Aboriginality: Authors on 'Being Aboriginal'.' In $A$ Companion to Australian Literature since 1900, edited by N. Birns and R. McNeer, 41-59. New York: Camden House, 2007.

Huggins, J. 'Always was, always will be.' In Blacklines: Contemporary Critical Writings by Indigenous Australians, edited by M. Grossman, 60-65. Carlton: Melbourne University Press, 2003.

Kral, I. 'Youth Media as Cultural Practice: Remote Indigenous Youth Speaking Out Loud.' Australian Aboriginal Studies 1 (2011): 416.

Lamb, N. 'Aboriginalising Racism - Regional Experiences of Racism Between Aboriginal Groups.' Paper presented at the International Conference on Racism in the New World Order: Realities of Colour, Culture and Identity Conference, University of the Sunshine Coast, Maroochydore, 2007: 177- 
183. http://www.usc.edu.au/nr/rdonlyres/b48e9bb0-04ae4d95-b710-512fd0973954/0/racismsconf3.pdf

Living Black, 'Cyber Wars.' Special Broadcasting Service, April 19, 2010.

Lumby, B. 'Cyber-Indigeneity: Urban Indigenous identity on Facebook.' The Australian Journal of Indigenous Education 39 (2010): 68-75.

Manago, A M., M B. Graham, P. M. Greenfield and G. Salimkhan. 'Selfpresentation and gender on Myspace.' Journal of Applied Development Psychology 29 (2008): 446-458.

McCormick, N. and J. Leonard. 'Gender and Sexuality in the Cyberspace Frontier.' Women and Therapy 19.4 (1996): 109119.

Nadarajah, H. 'Can You Be My Facebook Friend?: Reaching Out Across Language Groups.' Our Place: People Working With Technology in Remote Communities 39 (2011): 6-9.

Noble, F. 'Who Do We Think We Are: People Who Are Learning About their Aboriginality.' Unpublished Masters Thesis, Griffith University, 1996.

Overington, C. "Not so Black and White." Weekend Australian Magazine. March 24-25, 2012.

Oxenham, D, J Cameron, K Collard, P Dudgeon, D Garvey, M Kickett, T Kickett, J Roberts and J Whiteway. A Dialogue on Indigenous identity: Warts ' $n$ ' all. Perth: Gunada Press, 1999.

Paradies, Yin C. 'Beyond Black and White: Essentialism, Hybridity and Indigeneity.'Journal of Sociology 42, no. 4 (2006): 355367.

Papacharissi, Z, ed. A Networked Self: Identity, Community, and Culture on Social Network Sites. New York: New York, 2011.

Peters-Little, F. 'The Community Game: Aboriginal Self Definition at the Local Level.' In The Indigenous Welfare Economy and the CDEP Scheme, Centre for Aboriginal Economic Policy 
Research, edited by Frances Morphy and Will Sanders, 187192. Canberra: ANU EPress, 2001, Accessed May 132010.

Pullen, C. 'Introduction.' In LGBT Identity and Online New Media, edited by Christopher Pullen and Margaret Cooper, 1-16. New York: Routledge, 2010.

Robins, K. 'Cyberspace and the World We Live In.' In The Cybercultures Reader, edited by David Bell and Barbara M. Kennedy, 77-95. London: Routledge, 2000.

Subramanian, M. 'New Modes of Communication: Web Representation and Blogs: United States: South Asians.' Encyclopaedia of Women and Islamic Cultures (2010). http://referenceworks.brillonline.com/entries/encyclopedia-ofwomen-and-islamic-cultures/new-modes-of-communicationweb-representations-and-blogs-united-states-south-asiansCOM_0660

The Australian Institute of Aboriginal and Torres Strait Islander Studies conference titled 'Information Technologies and Indigenous Communities' 2010. Accessed at, http://www.aiatsis.gov.au/research/symposia/Digi10/theme.ht $\mathrm{ml}$

Yamanouchi, Y. 'Searching for Aboriginal Community in South Western Sydney.' Unpublished Doctoral Thesis, University of Sydney, 2007.

Yamanouchi, Y. 'Kinship, Organisations and 'Wannabes': Aboriginal Identity Negotiation in South-western Sydney.' Oceania 80 (2010): 216-228.

Zimmer, M. 'The Gaze of the Perfect Search Engine: Google as an Infrastructure of Dataveillance.' In Web search: Multidisciplinary Perspectives, edited by Zimmer, M. and A. Spink, A, 77-99. Dordrecht: Springer, 2008. 


\title{
READING RADMILLA: THE SEMIOTICS OF SELF (BLACK AND
}

\author{
NAVAJO)
}

\section{Ricardo Guthrie}

Hearing Radmilla, a documentary film produced by Angela Webb in 2010, tells the powerful story of a Navajo/Diné woman, Radmilla Cody, from Leupp, Arizona, who wins the title of "Miss Navajo Nation" in 1997, and who later falls from grace as a result of an abusive relationship that lands her in prison. The film, developed between 1999 and 2010, depicts Radmilla's dramatic recovery, and illustrates how she uses her singing and speaking skills to counsel and inspire other women. The rise, fall, and rise again of Radmilla follows a lyrical narrative that is common in many sociocultural texts, particularly film. But, what is different about this narrative is that it includes the mythic arc of race and identity - Radmilla's father was African American, her mother is Diné, and she was raised on an Arizona reservation by her Navajo grandmother.

In this essay, I examine the semiotics of being Navajo and Black in a society and culture that problematically embraces and rejects aspects of indigeneity and Blackness. Hearing Radmilla proclaims the strength of self-ascribed "biracial" children who overcome the stigma of race and cultural identity in a racialised society which privileges racial purity - however one defines that - yet proclaims itself as being tolerant and accepting of a world "beyond race." The purpose of this essay is to examine the semiotics of self, race and gender, as depicted in the film. My goal is to "read" Radmilla - the filmic archetype of Indigeneity and Blackness - and to uncover "Millie" Cody, the "imperfect-perfect" human being who undergoes dramatic 
transformations while striving to strip away the stigma, hurts and injuries of race, gender and Indigeneity in an imperfect society.

\section{Evolution of the Self: Navajo and Black}

Craig Womack $(1999,2)$ states that, "[T]here are a number of realities that constitute Indian identity - rez, urban, full-blood, mixed-blood, language speakers, nonspeakers, gay, straight, and many other possibilities..." In this dramatic evocation of Radmilla Cody's phenomenal life, the filmmaker, Angela Webb, provides Radmilla a forum for articulating the power - and danger-of growing up "biracial" in America. To be sure, Radmilla's life on film is not a generic iteration of biracialism - it is a close examination of two of the most contested, and problematic, racialised groups: Native Americans and African Americans. ${ }^{58}$ First and foremost, Hearing Radmilla is a formidable evocation of what literary theorist Craig Womack describes as "Native perspective," and an "indigenous consciousness":

...there is such a thing as a Native perspective and ...seeking it out is a worthwhile endeavor. ... I feel that Native perspectives have to do with allowing Indian people to speak for themselves, that is to say, prioritizing Native voices. Those voices may vary in quality, but they rise out of a historical reality wherein Native people have been excluded from discourse concerning their own cultures, and Indian people must be, ultimately will be, heard. (Womack 1999, 4-5)

It is clear that Radmilla embraces a discourse that challenges static depictions of Nativeness, while seeking resolution between Blackness

\footnotetext{
58 I will use Black and African American interchangeably, and I will use Native American, Navajo, Diné, and Indigenous as the context calls for it. In this approach to nomenclature, I am following other researchers, scholars and interpreters of race and popular culture, such as Kimberlé Crenshaw, Philip Deloria, and George Lipsitz. See, for example, Crenshaw "Race, Reform, and Retrenchment," Harvard Law Review, Vol. 101, no. 7, May 1988, 1332.
} 
and Indigeneity. The film, however, ultimately undermines her attempts to vocalise and embody an emergent identity that affirms both sides of her "biracial" experience. In addition, although she emerges as a spokesperson for women overcoming domestic violence and abuse, this aspect of the filmic discourse reifies her victimhood and raises more questions than it answers.

The filmmaker and editor combine plentiful images, sounds, and perspectives of Native American respondents, interviewees, and Radmilla herself, in articulating various dimensions of indigenous life in Arizona. Images of parades, the competition for Miss Navajo Nation, life on reservation ranches, photos from the Indian boarding school, and other depictions of Diné culture are all richly layered elements of the film that amplify Native perspectives. The perspectives are both enlightened and disturbing, as when Radmilla describes her feeling of vindication for winning the title, and the despair of reading letters from detractors printed in the Native press that she was "not really Navajo."59 Philip Deloria and other observers such as Sherman Alexie remind us, however, that both positive and negative perspectives about race are part of the indigenous experience. As Alexie stated:

Oh, yeah. I hear a hell of a lot more ni--er jokes on my rez than I did in the small farm town high school I went to. The thing is, it's all based on ignorance. There was one black person on the rez, and one in the farm town! (Talvi 1999)

59 "Miss Cody's appearance and physical characteristics are clearly black, and are thus representative of another race of people," wrote Orlando Tom, from Blue Gap, Arizona. "...[T] ribal members who are of mixed race are a threat to the future of the tribe," he added, even though Radmilla is fully enrolled and follows the matrilineal kinship of her Diné mother and grandmother. Quoted in Albuquerque Journal, March 1, 1998, A11. 
Radmilla notes that many supporters recognised her as a legitimate representative of Navajo culture, based on her matrilineal kinship, and being raised by her Navajo grandmother. Radmilla is of the Tl'aaschí'í (Red-Ochre-On Cheek) clan and is born for the AfricanAmericans. Her grandmother was a stalwart defender of Radmilla's right to the title as the $46^{\text {th }}$ Miss Navajo Nation - she spoke the language, explained the culture, butchered a sheep and prepared a traditional Navajo dish, better than other contestants who were considered "full-blooded" Navajo/Diné. Both the grandmother and Radmilla contested the prevailing belief that Indigeneity is strictly a function of race, rather than kinship and cultural upbringing. Even knowledgeable observers elevated race above kinship: "You know, she's part-Black and part-Navajo...," remarked Marley Shebala, a Navajo Times journalist, expressing admiration that Radmilla outperformed other contestants. Ida Organich, Miss Navajo Nation (1953) gave a backhanded compliment: "The others were full-blooded Navajo, but Radmilla was good!"60

Radmilla, however, grew up in the same environment as other reservation inhabitants, and never met her African American father until she was a grown woman in her twenties. By traditional indigenous perspectives, kinship, and sovereign rights, Radmilla was,

60 Celia Naylor provides an excellent discussion of the furor over Radmilla's selection as Miss Navajo Nation, examining newspaper commentaries, editorials, and responses, pro and con, over her racial and ethnic "authenticity" as a Native American. Naylor questions the debate over who may be accused of "playing Indian" (referencing Philip Deloria's historical framework for how "Americans" engage in racial ventriloquism to help suture together mythic, spiritual dimensions that can unify immigrants and ex-colonialists into a national grouping) and offers Cody's story as a cautionary tale over who ultimately determines what is "real" or authentic indigeneity. See Crossing Waters, Crossing Worlds: The African Diaspora in Indian Country, 2006, edited by Tiya Miles and Sharon P. Holland. 
and is, Navajo/Diné. But seen through the prism of race - her physical features, dark skin, full lips, etc. - she was considered "part Navajo."

Filmmaker Angela Webb effectively recounts the highs and lows of Radmilla's quest to represent the Navajo Nation, and provides interviews of other Miss Navajo winners who describe the lifelong challenges and notoriety that come with the title. Hearing Radmilla provides ample opportunities for Radmilla to be "heard," and she is an honest, courageous person for sharing her story. But there is a tension between Radmilla's performance of indigeneity on film (singing traditional songs arranged by her uncle, Herman Cody; speaking to native groups; and relating her cultural experience and upbringing as sources of strength), and the traumatic contestation over race and blackness that Radmilla/Millie endures.

Millie is a compelling storyteller whose different voices - Navajo daughter of mixed-race heritage; sheepherder and purveyor of Navajo language and culture; singer and performer of pop and traditional tunes; and representative of both the Navajo Nation and African America - are splendidly captured by documentary footage, interviews and interspersed photos, images, and newsclippings. Over the course of the film, however, the editing and use of such personal and observational revelations reinscribes Millie's voice and perspectives into a projection of trauma and triumph over violence and abuse by her boyfriend -who is revealed to be African American.

What begins as a personal saga of biracial identity discovery and transformation - being Navajo and Black in both traditional and nontraditional, rural and urban, settings - ends up as a problematic narrative of domestic abuse, Black deviance, imprisonment and atonement. There is no question that the story reflects Millie's voice and personal experience. The filmic encounters with Radmilla as competitor for Miss Navajo Nation - a blossoming indigenous 
ambassador, singer and performer of native and pop cultures, with heart wrenching descriptions of the impossible dilemma of having to testify against her boyfriend while perjuring herself, and the reaction to being incarcerated and then having to recover from two years in prison and revive her life and career afterwards - are all effectively conveyed.

What is problematic, however, are the segments of the story that speak louder than Radmilla: the binary of Navajo and Black is unbalanced and troubling - her idyllic life and trajectory as a young Diné recording artist and ambassador for the Navajo is interrupted by a dangerous detour after she falls in love and then tries to leave behind her "street smart" boyfriend in Phoenix. Rather than providing interviews with respondents who might be familiar with life in Phoenix and Black culture in general (recording artist Adina Howard and Millie's father, Troy Davis, are the only African Americans interviewed), viewers are left with the unmistakable impression that the worst thing to happen to Millie was to discover that being "Black" means suffering violence and abuse. In many ways, the story positions it as a "Whitney Houston" against "Bobby Brown" dynamic, and the end result is not pleasant.

By the end of the film, Radmilla takes responsibility for her fall from grace, and commits herself to counseling other young women against domestic abuse and towards confronting the stigma of being "Black" within Navajo culture. Both depictions are dramatic triumphs that are clear highpoints of her life; however, as the film allows Radmilla a chance to redeem and reinscribe what it means to be biracial and a survivor of domestic abuse, the film also inadvertently reinforces 
prevailing assumptions and presumptions of Black deviance and indigenous "otherness" that are still problematic. ${ }^{61}$

\section{"Dream on, Chocolate Mama!"}

Radmilla bears testimony to the difficulties of growing up Navajo and Black on an Arizona reservation. From her earliest arrival at her Navajo grandmother's ranch in Grand Falls (her mother, Margaret, was 18 when Millie was born, and the grandmother felt Margaret was not ready to care for a child), Radmilla was treated with curiosity, condescension and scorn. Her Uncle Rocky recalls being shocked that she was so dark: "What's this f-ing nigger baby? This ain't Detroit!" But Millie's father was not around to raise her - for reasons that are

${ }^{61}$ Sherman Alexie, in his poem, "How to Write the Great American Indian Novel," perhaps outlines a common theme that undergirds most of this filmic narrative: "All the Indians must have tragic features... The hero must be a halfbreed... preferably from a horse culture... There must be redemption, of course, and sins must be forgiven..." This is one-half of the story retold by Radmilla. The other half, about the African American subculture, is weakly explored by the filmmaker. Millie's father, Troy Davis, enters her life after he learns she has won the Miss Navajo title in 1997. He admits that he wished he had been around to advise her and protect her from the "street smart" guy who became her boyfriend. No one else is interviewed to explore or explain the many perspectives of African Americans in U.S. society-how the "hidden transcript" of race bolsters the antiblack sentiments that pervade American culture. Despite W.E.B. Du Bois's theorisation that "the problem of the twentieth century is the problem of the color-line," by the time Millie came of age in the 1990s, discrepant images of blackness and African American culture were still dominant and in effect. The hegemonic discourse of black deviance, pathology, urban decline, and sexual attraction/repulsion are yet inscribed within this "documentary" film, as viewers are slowly introduced to boyfriend Darrell-street-smart Black hustler, violent abuser, who coerces Radmilla into running drugs for him. Although Millie survives to tell a triumphant story, the narrative that being Black is a curse from which she cannot escape remains unchallenged. 
not explained in the film - and Millie did not meet him until she was a grown woman who had already competed and won the title of "Miss Navajo Nation" in 1997.

Nevertheless, her uncles grew to love her, even as they taunted her about her Black heritage. "That's my cocoa-mama," Uncle Rocky proudly proclaims in the film, pausing to weep over the memory. And this, then, is perhaps the film's strongest aspect: capturing the comments and heartfelt reflections of those closest to Millie, including her uncles, her grandmother, her mother, friends, and commentators such as other Miss Navajo contestants, and journalist Marley Shebala. Shebala notes, "she was that perfect person, who was imperfect," discussing how Miss Navajo was not supposed to exhibit any flaws while representing the Nation.

The film "hears" Radmilla as she describes her bucolic, rural upbringing in traditional Navajo culture: raising sheep and goats, learning to grow crops and cook traditional foods, tell Navajo stories, and her early proclivity for music and singing. "I was Whitney Houston - singing to my sheep and nanny goats, out on the plains," she declares. "I would serve them cake and sing 'Happy Birthday'; they were my greatest audience!" Millie's early years on her grandmother's ranch were interrupted when she was sent to an Indian boarding school in Leupp, Arizona, where she was challenged to assimilate to American culture, along with the other indigenous students.

"I was taunted [for being Black and Navajo] as a kid," she said. "There's a word for 'Black' in Navajo: 'Zhini', which is synonymous for 'nigger'..." But, her grounding in Navajo culture ultimately provided a bridge between her and other Diné children during the boarding school years. She attended school in Leupp on and off from kindergarten to high school, before she enrolled in Coconino High in Flagstaff. She knew nothing about being African American, and had 
never heard of Martin Luther King or Malcolm X, testament to the restrictive boarding school environment, which belittled Black and indigenous culture and knowledge.

Boarding schools have been cruel training grounds for indigenous children throughout American history, and they embody the conquering logic of how Americans sought to "assimilate" Indian "Others" through cultural genocide. "We were punished for speaking Navajo," Radmilla recalls. So the children practiced speaking Navajo secretly among themselves. In this way, shuttling between Leupp and her grandmother's ranch, she developed an appreciation and understanding of two different worlds.

The institutionalising coercion of Indian boarding school was offset by real-world lessons in Diné culture, language, and tradition that were practiced and reinforced by the other children, and by her grandmother and uncles. Radmilla learned the strength, and the dangers, of being Navajo, Black, and living under a coercive institutional regime. She also met the reigning "Miss Navajo" at the Leupp boarding school, and imagined some day competing for the honor of representing all Diné/Navajo.

Her Uncle Rocky recalls: "She told me: 'Hey uncle, I'm gonna be that!' I told her: 'Dream on, Chocolate Mama!'” But before she could compete for Miss Navajo Nation, Radmilla left the reservation to enroll in college down in the big city - Phoenix, where she encountered another world that was attractive yet challenging in many ways. Her close friend, Adina Howard, recalls in the film: "That was Millie...like the Amish off the Rez" - fresh off the farm, and not ready for city life. "My curiosity led me to a lot of bad decisions," Millie remembers. 
At this point in the film, Webb asked her if she wanted to talk about her boyfriend. Millie paused, and began to tell the story of falling in love, living in the fast lane of cars, music, parties, and, ultimately, abuse. Her boyfriend sold cars, but also ran drugs; he coerced Millie to traffick drugs through the Phoenix airport for him. She was too scared to resist, and suffered violent abuse: "It started with a push, and escalated. I was black and blue from the beatings..."

Finally, she left Phoenix, returned to the reservation, began her singing career, and became Miss Navajo Nation from 1997-98. "I was not allowed to have a boyfriend, so I was away and had time to heal," she recalled. She was only 23 when she moved to Window Rock, and fought back against those who derided her mixed heritage.

Her singing was the blessing that became a bridge to others. "We have a lot of respect for singers," noted Marley Shebala."Our prayers are songs...." Radmilla released CDs in 2000 and 2001 with her uncle Herman. They were compilations of Navajo songs that featured unique instrumental accompaniments. She was the "queen of two cultures," according to newspaper clippings of the period, speaking to Black History Month audiences, and traveling around the state as a proud goodwill ambassador. Her evolution as a spokesperson for Navajo and as a performer was nearly complete; however, after finishing her term as Miss Navajo, she returned to her boyfriend, Darrell, who was increasingly jealous of her success as a singer and recording artist. "I still loved him," Millie said, even though she suffered more physical abuse and was ultimately called before a Grand Jury in Tulsa, Oklahoma, to testify about her knowledge of Darrell's drug operations.

Millie, AKA "Marilyn Kelly," was indicted and later convicted for withholding information about her own involvement in her boyfriend's drug running. Her attorney presented evidence that Millie 
was a victim of violent abuse and physical coercion, but the federal prosecutors and the judge discounted her testimony of abuse because she had not fully disclosed how she had transported drugs to and from the airport. Her sentence, after pleading guilty to "misprision of a felony," netted her 21 months in a federal prison camp. She began serving time in 2002 and, though it was prison, she said "It felt like boarding school..." in which she examined her life, her beliefs, and the actions that led to her imprisonment.

She was derided in newspapers for bringing disgrace to the Dine nation as a former Miss Navajo. Although it was a very difficult period for her, "It was a blessing - to be able to look at myself, and heal," she said. When Millie completed her sentence in July 2004, she was determined to talk to women on the reservation, and around the world, about surviving domestic violence. "A lot of people on the Rez were going through the same thing," Marley Shebala said. "But she was a role model," so she had to explain how even Miss Navajo was not immune to violence against women.

\section{Not Zhini...but African American: “A Dark Calmness”}

Radmilla left prison and resumed her recording career, releasing albums in 2005 and 2006, and taking on another cause as well: "A medicine man told me of another word for African Americans: 'Na 'hii 'she' - meaning 'dark calmness, one-ness'... not Zhini, but a new word." Millie says part of her mission now is to teach a new understanding of African Americans to other Navajo children - and to combat prejudice against biracial people.

The narrative arc of the film concludes with her tearful "homecoming" speech, and an elaborately produced music video from her album. Radmilla/Millie is resurrected and whole - but the carefully constructed ending relies on a somewhat mythic evocation of 
reclaimed native performance. The slick editing and smooth video transitions between singing on the plains and sitting indoors before a mirror undermine the supposed transformation and release of this remarkable person. The music-video production underscores how performances of race and Indigeneity are often packaged and arranged for consumption by audiences and listeners who develop appetites for merged identities which can reinforce their expectations of what is good, valuable, or useful in American Indian culture. As Philip Deloria notes, the value of Indian culture evokes desire and revulsion, and production of "ethnic gifts" that can be used to affirm a (false) "American" pluralism:

Since the colonial era, Indian Others had been objects of both desire and repulsion, and in that raging contradiction lay their power. Now, they [are] almost completely flattened out, tragic victims who brought the last powerful remnants of their cultures as ethnic gifts for a pluralist American whole (Deloria 1998, 175).

Radmilla has a beautiful singing voice and a captivating presence on screen and in person, and to the Navajo/Diné she can be admired for advancing and popularising Navajo songs. She can also challenge Diné to be more accepting of "mixed-race" people who are part of the Navajo nation. To African Americans she can express levels of understanding about being Black in a white world. To non-Black and non-indigenous peoples she can represent all that is attractive, exotic, and yet problematic to the white world - gazing upon her rise, fall and rise again. The film bears witness to the effect of racism and violence against women, but it clumsily reduces Millie's personal triumphs into a polemic against domestic violence and black masculinity. When it might be a platform for better articulating emerging identities that exceed simple binaries of race or nation, it is lacking effective analyses or respondents who could comment on the tensions and lingering questions of the meaning of Navajo/Black identity. 
Radmilla proclaims her "biracial" heritage, but her explication - and her experience - is mostly as a "non-white" person whose traumatic journey fits standard tropes of the racialised "Other" who is attractive, desirable, but exoticised and ultimately scorned because the dominant world refuses to accept her as a multidimensional person. Her music video inscribes an acceptable performance of Indigeneity, even as she sings lyrics that exalt her journey of discovery beyond Native American themes. Further, the unexplored sign and signification of "Blackness" remains obscured by the damaging encounter with her convicted ex-boyfriend, drug kingpin Darrell, and the lingering questions about the loving, absent Black father. This type of "trauma drama" - in which viewers are invited to witness the violence and abuse inflicted on victims by African American males - may elicit a cathartic response by knowing survivors such as Radmilla/Millie; but more often the cathartic response reinforces misplaced beliefs that Black culture, and Black men, are best avoided, even by those who profess to love black culture.

Such narratives conform all too easily to established themes of racial subjugation that support the logic of continued white dominance over indigenous and African American peoples. Ultimately, to be biracial Black and Navajo - only compels pity and charity, rather than empowering or liberating those who carry the mantle for both groups. It is the unintended consequence of the film that manufacturing an image of Radmilla performing legible identities occludes Millie's valiant evolution and transformation as a Navajo/African American, performer, and resilient counselor of abused women. The film relies upon a simplistic trope of an abused biracial woman (non-white), who is punished for her sins, yet emerges triumphant to tell a transformative story to other women and victims of Black violence and deviance. 
Millie's performance of indigeneity stabilises her identification but it is illegible and invisible to viewers about what it means to be Black, and desirable, in Navajo and non-Black environments. Radmilla has escaped the boarding school and the prison, but she remains incarcerated within the fictive imaginary of biracial identity formation that may yet emerge through the tensions of merged consciousness and experience. ${ }^{62}$ Hearing Radmilla says far less about Millie being heard, than about the tensions and conflicts of racialised identities with which she has wrestled throughout her life. It requires more forthright respondents from the African American perspective, or perhaps a deeper explication from Millie herself: her feelings, hopes and fears, written in her own words, and mined from the journals, diaries and letters that she wrote during her incarceration. She has grasped what it means to be Black and Navajo, and using the words of Leslie Marmon Silko, beckons all of us to join together as her sisters

62 Jared Sexton evaluates the historical evolution of "mixed-race" identity movements in the United States, and declares that biracial peoples--even as they agitate for recognition as existing outside of a simple black/white binary-are trapped within a "white/non-white" racial prism because white dominance, and supremacy in sociocultural as well as political-economic domains, remains firmly in place. The "afterlife" of slavery, he maintains, has yet to allow non-white subjects to secure meaning and standing in American society. Thus, "biracial" peoples are still measured by how much (or how little) they resemble "whites" in phenotypical dimensions-regardless of their cultural affinity for the dominant culture. Native/indigenous, or non-white "others," who are "raced" with Blacks or other non-whites, do not exist as "biracial" others occupying a "third space or race," so much as they exist as "non-white" others jockeying for position between raced subjects whose identities, histories, and cultures are already being erased, appropriated, or reinscribed by the dominant culture. For these "others," physically escaping the ghetto, reservation, boarding schools, and prisons might be possible, while the narratives of deviance and subjugation follow them wherever they go. See Sexton, "People-of-Color-Blindness: Notes on the Afterlife of Slavery," Social Text 2010 28(2 103): 31-56. 
and brothers: "In the view of the old-time people, we are all sisters and brothers because the Mother Creator made all of us - all colors and all sizes. We are sisters and brothers, clanspeople of all living beings around us" (1996, 63-64).

\section{References}

Alexie, S. The Summer of Black Widows. Brooklyn: Hanging Loose Press, 1996.

Crenshaw, K. 'Race, Reform, and Retrenchment,' Harvard Law Review 101, 7 (1988): 1331-1387.

Deloria, P. J. Playing Indian. New Haven: Yale University Press, 1998.

Du Bois, W.E.B. The Souls of Black Folk. Boston: Bedford Books, 1997.

Guthrie, R. 'Oprah Winfrey and the Trauma Drama: 'What's So Good About Feeling Bad?' in Presenting Oprah Winfrey, Her Films, and African American Literature, edited by T. T. Green, 4578. New York: Palgrave, 2013.

Lipsitz, G. The Possessive Investment in Whiteness: How White People Profit from Identity Politics. rev. ed. Philadelphia: Temple University Press, 2006.

Lipsitz, G. Time Passages: Collective Memory and American Popular Culture, Minneapolis: University of Minnesota Press, 1990.

Naylor, C. 'Playing Indian?' The Selection of Radmilla Cody as Miss Navajo Nation, 1997-1998.' In Crossing Waters, Crossing Worlds: The African Diaspora in Indian Country, edited by T. Miles and S. P. Holland, 145-163. Durham: Duke University Press, 2006.

New Yorker, 'Q \& A: Redeemers: Sherman Alexie Talks about His Native American Heritage...' The New Yorker Online, April 21, 2003: http://www.newyorker.com/archive/2003/04/21/030421on_o nlineonly01. Accessed May 6, 2013. 
Sexton, J. 'People-of-Color-Blindness: Notes on the Afterlife of Slavery.' Social Text 28 (2010): 31-56.

Silko, L. M. Yellow Woman and a Beauty of the Spirit. New York: Simon \& Schuster, 1996.

Talvi, S. 'Sherman Alexie Isn't Who You Think He Is.' COLORS NW Magazine, December 6, 2003.

Womack, C. Red on Red: Native American Literary Separatism, Minneapolis: University of Minnesota Press, 1999. 


\section{REFUSING NOSTALGIA: THREE INDIGENOUS FILMMAKERS’ \\ NEGOTIATIONS OF IDENTITY}

\section{Jeff Berglund}

“Everyone assumes you've made a 'grandma' movie or you have at least one featuring sheep," said filmmaker, Ramona Emerson, during a conference featuring the Southwest's best U.S.-based indigenous filmmakers. Emerson, who is Diné - known to the rest of the world as Navajo - was making somewhat of an insider's joke, as insinuated by her follow-up comment: "or a movie about a grandma with some sheep!” That joke got even more laughs as it likely brought to mind a number of Navajo-produced movies - highly crafted short works beautifully documenting, representing, or imagining the life of esteemed elders, particularly grandmothers. In 2009, Blackhorse Lowe had recently made one titled Shimásání (the Navajo word for maternal grandmother), and years ago the most well-known Navajo-directed film, Navajo Talking Picture (1985), featured the director's grandmother, albeit as a reluctant ethnographic subject of her granddaughter's filmmaking assault. It also featured sheep and sheep butchering. None of which was surprising given the well-known Navajo aphorism, "Sheep Is Life." Emerson's joke and Diné audiences' memories of related films provide evidence of the twin poles of expectation: first, that as Diné filmmakers, there are typical subjects around which to develop films and, second, that to disentangle, disassociate or disambiguate oneself from such codes is to risk questions about being Navajo, about being different from other Navajo filmmakers, or at its most extreme, about being authentic. To distance herself from such expectations, Emerson, for one, created her newest film project, Opal (2012), about a bullied but feisty young 
Navajo girl who loves Charles Bronson and the rock band KISS. Another Diné director, Melissa Henry's gem of a movie, Horse You See (2007), featured a talking horse, speaking exclusively in Navajo, instead of sheep or grandmothers. To the audience gathered in Albuquerque, Henry warned about the dangers of being pigeonholed: "It will break creativity. It will be limiting. I'm a filmmaker" (Emerson \& Henry, 2011).

This chapter focuses on such thematic tensions in the creative work of three young indigenous filmmakers from Arizona in the United States: Deidra Peaches (Diné), Donovan Seschillie (Diné), and Jake Hoyungowa (Hopi \& Diné), known collectively as Paper Rocket Productions. ${ }^{63}$ Their collaborative productions afford viewers and scholars alike the opportunity to understand the artistic and political trade-offs and consequences of working at Native filmmaking. This, in turn, includes the implications of being identified by their tribal backgrounds, and of how the medium of film offers different means of exploring, representing, and creating identities that resist fossilised notions and expectations: some that pre-date intracultural filmic productions, and others that have grown up alongside developing trends - alluded to above - within the first four decades since Navajocentered and directed films have existed. I see my reflections as a way to bring attention to their work, the beauty and technical skill exhibited in it, but also as a reflection on the contemporary process and challenges of making films outside of the commercial industry and within the support network of indigenous filmmaking and producing, including grassroots organisations such as Outta Your Backpack Media (OYBM), ${ }^{64}$ based in Flagstaff, Arizona, and Longhouse Media, ${ }^{65}$ based in Seattle, Washington. While it doesn't

\footnotetext{
${ }^{63} \mathrm{http}: / /$ www.paperrocketproductions.com/

${ }^{64}$ http://oybm.org/

${ }^{65}$ http://www.longhousemedia.org/
} 
interest me to offer arguments about how their work leads to shifts in Diné or Native epistemologies - I'll leave that to the anthropologists - I am primarily interested in their individual and collective negotiations within this network of being filmmakers who are Native, of being Native filmmakers, and of being supported as filmmakers who make Native films because they are Native filmmakers. Based on numerous interviews, shared viewings, and analysis of their films, this chapter discusses how these filmmakers navigate competing claims on their artistic vision while simultaneously advancing their own version of contemporary Native/Navajo (and Navajo/Hopi) identities.

Navajo people have been rooted in the Southwest for centuries, and according to Diné origin narratives - since time immemorial. Outright genocide and massive colonial disruptions have irrevocably changed patterns of life and modes of reflecting on its meaning and value. Traditions continue to evolve and undergo shifts, challenged by those claiming to be traditionalists, claiming that what once was, must continue to be. While there may be core consensus regarding culturally sacrosanct philosophies and cosmologies, the mode of transmission of this knowledge and of Diné epistemologies has undeniably undergone shifts and continues to be challenged further with the rise of different technological innovations.

By 2011, for example, filmmaking by Navajo directors, cinematographers, and producers is no longer an innovation that interests current anthropologists - unlike their 1960s counterparts. Here I am referring to John Adair and Sol Worth's project, culminating in the 1972 publication of his book, Through Navajo Eyes, wherein the anthropologist looks for filmmaking innovations and disruptions that intersect with Navajo cultural patterns and epistemologies where "the Navajo didn't follow the rule of editing on motion or action at all. The notion of smoothness of action or making 
a connective unnoticeable didn't seem to occur to them, or wasn't important enough to do anything about, except in specific cases..." (171). In this passage, Adair and Worth are interested in pointing out how aesthetic effects are linked to tribal and traditional ways of seeing the world. Taken literally, Worth's study suggests that knowledge of tribal worldviews would predetermine filmmaking strategies. In Shimmering Screens: Making Media in an Aboriginal Community (2003), Jennifer Deger locates the opposite but similarly limiting methodological tendency in an ethnographer such as James Weiner who claims, "The camera threatens to obscure and even erase traditional modes of being" $(2003,53)$. In both instances, according to these perspectives, technologies of filmmaking and traditionalism do not truly interact to produce modes. By contrast, Deger $(2006,40)$ prefers to see that indigenous cultures and subjectivities are emergent, processual, and responsive, and that films being produced by indigenous artists may instead be seen as "sensuous modes of perception," a notion I hope to echo in this chapter.

From my vantage point, currently, Diné-produced film is alive and thriving. I've carefully avoided the word "flourishing" because it's neither a successful economic enterprise, nor a well or easily funded venture. Nonetheless, there exists a cadre of incredibly dedicated and talented filmmakers who refuse to lay down the camera, who squeeze the blood from the proverbial turnip to buy editing software and equipment such as new cameras, memory sticks, and hard drives, who assemble crews, who pay entry fees to festivals, and who have worked hard to graduate from film and television programs. The founders of Paper Rocket Productions-Donovan Seschillie, Jake Hoyungowa, and Deidra Peaches - have done everything to support their neverending drive to produce satisfying, if not breath-taking, films outside of the formal training of college level programs. In June and July 2011 - after temporary stints as custodians/janitors - they worked on film 
crews shooting in New Mexico, in Montana, and then earned prestigious mentor positions at Longhouse Media in Seattle, Washington.

These three successful filmmakers are all products of a local, activistoriginated filmmaking workshop for Native youth. Outta Your Backpack Media - an indigenous youth workshop and resource distribution effort - provides youth access to filmmaking from inception to production, filming, and editing. Klee Benally, the lead singer of Blackfire and the founder of indigenous Action Media, has operated OYBM since 2004 out of Táala Hooghan, his infoshop in Flagstaff, Arizona. OYBM has, in the words of the organisation's vision statement, "empowered indigenous youth through free movie making workshops and resource distribution. OYBM is an indigenous youth response to the need for media justice in our communities" (Outta Your Backpack Media 2011). In conversations I've had with Klee Benally, he often notes the following: "We seek to create community ownership of media through youth empowerment. We challenge corporate dominated media by telling our own stories and by establishing our own networks and opportunities for media distribution. We emphasise resource access for youth with a focus on media literacy."

With access to the these tools, indigenous youth are telling their own stories in unique and unexpected ways, all reflections of multiple aspects of their identities, not readily identified as "traditional" or tribally centered. This mix of film technology and its intersections with regional, tribal, and personal interests inspires indigenous youth to find meaningful engagements with elements of their cultural heritage, though often in indirect and subtle ways. Working with an activist-oriented filmmaker such as Benally, the filmmakers educated by Outta Your Backpack Media also learn about the decolonising 
possibilities of filmmaking, recognising that their self-representations, stories, and documentaries work to counter the legacies and the ongoing stream of misrepresentations of indigenous peoples. Part of the resistance to the legacy of misrepresentation is a clear eschewing of expectation and the burden of fulfilling others' notions of Indigeneity. A few years ago in a visit to one of my classes, Klee Benally was joined by one of his lead youth mentors, Shelby Ray, who described her own experiences of coming into this sense of empowerment: "[When] I first became involved I was just a participant, from the first workshop, going through [the] process of filmmaking, and [this] led to other experiences, going to the Smithsonian Film Festival in NYC and traveling. For me, it's in my opinion [all about] giving voice to your perspective." (Bennally 2009) For others, especially Deidra Peaches, Donovan Seschillie and Jake Hoyungowa, what OYBM represented was access to expensive equipment, including editing software. Don says, "When we were young, we weren't fully aware of everything [politics, etc.], but as Deidra explains, we were 'attracted to OYBM by the equipment"' (Seschillie 2010). As Donovan continued, further explaining his own experiences as a mentor, "What's the best part of OYBM is the contribution to Native youth in the community, it's free, [it inspires] youth empowerment. Some of the kids come from very chancy homes, very poor and they come to use the internet, from some homes where they can't afford the internet and some of the cameras cost $\$ 3000$, so we'd think of a story to make, grab a camera and just come back and edit it. Which is pretty cool. Getting them tools to tell their own social stories. That's what I like about it."

Student projects at OYBM range from public service announcement films about smoking, date-rape, drug addiction, and diabetes, to documentaries on protests against artificial snowmaking on sacred mountains, and uranium mining and pollution, and to humorous take-downs of popular media and American myths - one on the 2008 
film Twilight and its representation of Native peoples is particularly amusing, as is a lampoon of the Thanksgiving holiday and its mythic origins. Other films feature the Diné perspective on the value of water, and explore the beauty and wonder of the imagination. One features a "stick man" who comes to life and another, titled Imagine (2007), explores the imaginative play of children and provided the original inspiration for one of the longer films, Rocket Boy (2010), which I will discuss later. Deidra Peaches conceived Imagine for the National Museum of the American Indian's showcase "Thanksgiving Revisited: New Views by Young Filmmakers." She says, "It started with the question, what are you thankful for?" I decided to make a video that was thankful for my imagination. So it was about a boy playing in a box, wondering how far you could let your imagination go, even though you didn't have all of things. One aspect of it was a boy who built a rocket and he ends up launching it. It was just done with cardboard, spray paint and camera tricks" (Seschillie 2010).

Another stand-out filmmaker from this organisation, Camille Tso, the youngest mentor in its history, made a 29-minute film, In the Footsteps of Yellow Woman (2009), a story of her grandmother that is further entangled in a more familiar narrative of the Navajo oratory canon. It's worth mentioning the two poles of Camille Tso's experience: at age nine she was in front of the camera when she worked as an extra in Steven Spielberg's Into the West (2005) television series; at age fourteen, after time spent behind the camera, she was showing her film at the Smithsonian's Native American Film Festival + Video Festival in New York City and the San Antonio Film Festival, as well as receiving a scholarship to attend the prestigious arts boarding school, Idyllwild Arts Academy. The films produced in conjunction with OYBM clearly focus on a variety of topics, and filmmakers find value in play, in resistance to expectation, and in their own particular attachment and recognition of intrinsic tribal and 
cultural values that may or may not mesh with activist efforts and a social justice agenda. Efforts such as Klee Benally's Outta Your Backpack Media are commendable, and luckily, not singular. Around the United States, other programs exist - some even more substantial and successful in producing bigger productions and garnering more attention. Seattle's Long House Media and its youth media project, Native Lens, both founded by Tracy Rector (Seminole), is a case in point. Rector brought her expertise in education to the organisation and was recognised with the National Association for Media Literacy Education Award in 2009. Long House has fostered a long line of indigenous filmmakers, including one current group that is making a full-length film adaptation of the James Welch (Gros Ventre) literary classic, Winter in the Blood (1986). Jake Honungawa and Deidra Peaches worked on this film in Montana in 2011 after each, respectively, concluded a prestigious and competitive internship with the headquarters of Long House in Seattle. Prior to this, Deidra Peaches participated in the 2008 SuperFly Filmmaking Experience in Seattle, and Jake Honungawa mentored at the 2009 SuperFly and reservation-based programs. Jake characterises these experiences in Longhouse's promotional material: "Working with Longhouse Media as a mentor in filmmaking has given me a greater perspective on being a member in my own Native community and Native lifestyle forgotten to some; however, reclaimed by a few" (Longhouse Media 2011). When I asked him about his work there, he chose to focus on a reservation in Idaho. "When we were in Idaho working with Longhouse Media, I met a kid who liked cameras and I was able to help him learn more, to get into it more. Kinda just to inspire him to keep going with it." Not surprisingly, the technical side of the process is what interests Honungawa most. Similarly, Donovan Seschillie noted that, compared to OYBM's emphasis on activism, "At Longhouse it's more about the filmmaking process" (ibid.). 
The first video that grabbed my attention on OYBM's YouTube channel was a delightful short film, Real Love, (2007) directed by Deidra Peaches. ${ }^{66}$ Real Love features characters in paper bag masks engaged in a romantic plot where love is desired, earned, lost, spurned, desired and earned again, all without dialogue. Filmed in a rich, sumptuous saturation of colour, it's set to the extra-diegetic Beatles' song "Real Love." This 3:51 minute film is a showcase for technical skill and thwarts viewer's expectation that identities will be revealed. Through alterations to the drawn-on faces, viewers watch the shifting emotions of characters in love, particularly as the primary male character's emotions shift from attraction to despair when competition throws his surety into question. Eventually, this despairing protagonist sees a new love interest. It begins raining, but the rain signals possibility and regeneration. Pink and red paper hearts start falling during the rain-shower. They walk hand in hand, run, play on the merry-go-round, talk, and laugh, as The Beatles track continues to repeat, "It's real love ..." "My thoughts having paper bags on the characters' heads," Deidra explained to me, "was to provide no distinguishing features of race or of different colour skin. Everyone was pretty much the same. And I wanted to show that emotions run the same, too, within all races. It wasn't pinpointing a certain race. I could've had people not wear the paper bags, but it wouldn't have had the same effect. But showing that similarities between people, the emotions - we all experience love, we all experience hate, we all experience fear - those are the themes I wanted to portray in the film."

When I brought up the response of one of my student viewers who asked me how this short was a "Native Film", Deidra responded, "I know one thing I would say before answering is to ask the question, 'What is Native film?' And there's no definition saying what Native

${ }^{66} \mathrm{http}: / /$ www.youtube.com/user/outtayourbackpack 
film is. I think this question falls into the same category. You could be non-Native making a film about Natives and would it be called a Native film? I think it's just as limitless as the video itself. That's why there's no dialogue in the film. It's all open to the audience's interpretation." I asked Jake and Donovan about their responses, too. Donavan said, "I just laugh. I think it's a stupid question. I think it comes from what they expect Native films will be." When asked about who their intended audience is, Deidra, Donovan and Jake are pretty consistent as well. Deidra, notes, for example, "Some of the Navajo filmmakers are just making films for other Navajos. We try to avoid that with our films. [We're going for] an emotional connection that all people share" (Seschillie 2010).

In summer 2010, in the offices of Native American Student Services at my university, Northern Arizona University, I saw a rough-cut of two of their then-recent films and finally had a chance to connect with these three talented and generous filmmakers. Deidra was still editing her very own film Shimasani (2009) - remember, that's Navajo for maternal grandmother - a movie about Lilly Manygoats, though it had debuted in 2009 at the Imaginative Film Festival in Toronto. At 3:43 minutes, Shimasani might seem completely different from Real Love (2007) in its exposure of a specific individual and her cultural inheritance. Strikingly, Deidra's grandmother's face is not once shown; viewers come to know her through her hands and her voice speaking Navajo - and the objects in her home the camera lingers on while she speaks. The faces of grandchildren enjoying her cooking and the focus on daily rituals - from morning prayers, to work with her sheep, to butchering, as well as the beautiful land that cradles her existence - underscore for viewers the impact of her beliefs and teachings. 
A string instrument soundtrack imbues the film with a serious, but not too dark, tone. In the first seconds of the film, the dawn's light displays the grandmother's hands sprinkling pollen: "You must always have your corn pollen. You pray, 'I walk in beauty at dawn' and that is what you live by. That is what you call LIFE and that is how you pray" (Shimasani 2008). Her words are matched by the camera panning over the red cliffs still in shadow, the sun not yet up over the horizon in the east. The camera then follows grandmother into her home and, as she talks about daily activities, we see up-close objects in her. Among other things, we see smoke coming from a chimney, a straw broom brush, a basket of fresh corn, tied dried corn, wedding baskets, images of Indian buffalo hunters, horse figurines, the grandmother's hands, sheep, herding dogs, a cornfield, butchering sheep, roasting mutton, and several methods of cooking corn. "You can cook corn in many different ways [close up of fire]. For example, dry corn to cook with soup or kneel down bread, for example this is what my late grandmother taught me." Viewers learn that the everyday ways of life for the grandmother play in and out between prayer and ceremonial life. Directly after her advice for cooking corn, she continues, "The ceremonies and prayers help you children think clearly. And live in harmony. Even if they live far away from home, ceremonies and prayers will keep them protected while they're travelling. That way they remember where home is. That is always why you should have a cornfield and sheep. That's what you eat to survive. When we butcher the sheep and cook the meat it will taste delicious." Viewers can't help but note Jake Honungawa's fluid, beautiful cinematography. The expert control of tone and emotions further supports the filmmaker's appreciation and validation of her grandmother, and her beauty and wisdom.

Equally commendable is Deidra's willingness to include her grandmother's lament about the generational divide that exists due to 
the decline of Navajo speakers: "It's kind of difficult and frustrating I think when your grandchildren don't speak the Navajo language and you're not able to understand each other. It's very difficult when your grandchildren only know one language (English). You want to talk to them but you're not able to." (Shimasani 2008) Here, through wise tonal editing decisions, the camera focuses on corral fences used for butchering. Peaches' grandmother continues, "If they understood Navajo it would be good for them. I would be able to teach them. If they spoke both spoke Navajo and English well it would be wonderful." The eloquence and simplicity of the choices Peaches has made serves as a clear reminder to viewers that grandmother and granddaughter might share the same knowledge and values, even though the medium may no longer be the Navajo language. The concluding shot of the film is the same as the opening scene: the grandmother surveys the landscape, but this time the evening light is directed from the west. The cinematographer and director - from on site and in the editing room - encourage us to direct our attention to where the grandmother is looking.

When I asked Deidra the official title of her movie - it was untitled when I first saw it, and unlabeled in the cut she leant me - she smiled and said, "I call it 'Shimasani, the Grandma Documentary,' just to confuse people" (Seschillie 2010). This struck me as an outright nod to the generic expectation of the type of film she might make. Of course her use of the definite article "the" also makes me think it's her fulfillment of the burden of expectation: Okay, I've done it. Here is the movie you expect me to make.

Regarding questions about filmmaking and its intersection with culturally relevant materials, Jake explains that from the Hopi perspective (the culture in which he was raised, though he is also Diné), tribally specific values are a way of life. "You'd have to dedicate 
your entire day to rituals and beliefs - I try not to bring that into my filmmaking... Hopi culture is really enclosed and they don't want to bring their culture out into the world too much. I guess I can respect that as well. I see first-hand wanting to go there and make a film. The village elders told me never to go down in the village and make a film. And, I gotta respect that from now on" (Seschillie 2010). By contrast, during the interviews, Deidra said, "with me, a lot of culture goes into it, even though I don't practice the culture. It's about my relatives and the people I've grown up with have suffered from boarding schools, suffered from relocation, suffered from not having resources that people outside of the reservation have. I think as a filmmaker, I want to show that different perspective on life, that perspective of not having a lot, that perspective of not having a lot of amenities that we might take for granted. People who live off the reservation have access to water, easy transportation, all of these things that people who live off the reservation have readily available. What I like to portray is that people don't have all of these things accessible to them... I think visual filmmaking is a way of showing audiences that this is happening. As a filmmaker, and as a Navajo person, I have every right to show that and that is really important right now and that is my contribution" (Seschillie 2010). All of these are social justice issues linked to her community today and imbricated in colonial legacies, and not necessarily cultural traditions that she feels compelled to project to the world.

In my discussions with Deidra, Donovan, and Jake, it is very clear that the driving force behind their work is their artistic ambition of producing, on a technical level, the very best films, and that are also available to all audiences. Jake shared with me his primary obligation and motivation: "It's the overall creativity, all the technical aspects that go into it. That's all really fun to me. Getting to learn all the different tools. Just writing your own stories as well. It doesn't have to be 
about Navajo or comedy, just going off on personal experiences. There are funny times living with my parents and grandparents. There are sad times too, gotta bring those out too. A lot of our personal narratives for now" (Seschillie 2010).

Without a doubt, their recent film, Rocket Boy (2010), has been their greatest collaborative success. It was accepted by the short film division of the Sundance Festival, chosen as one of only sixty films out of 650 submissions, and they are, to date, the youngest Native filmmakers to have their work accepted. I'll never forget the moment when, on December 6, 2010, I received a phone call from Deidra: "Jeff... We got into Sundance!! We can't believe it! We found out 15 minutes ago!" In addition to Sundance, their film has been shown at numerous festivals, including the Smithsonian Native American Film + Video Bienniale where Rocket Boy featured prominently in their 2011 promo reel.

This success was slowly earned. Donovan explains, "We entered Rocket Boy into a lot of Native film festivals and it got denied and it surprised lots of people. We went to Santa Fe and we told people that ImagiNation, one of the biggest film festivals in Canada, didn't accept Rocket Boy. Also San Francisco American Indian Film Festival rejected it. We did show in Santa Fe. I joke we should've added in some flute music... I guess our film is out of the market. So many of the films in the program are socially oriented, for example, water rights, stories about pow-wows, families, and then there's this film about a rocket boy by Native Americans about a little boy who has this ambition of going to space. It's very stylised and is science fiction and doesn't really match with the program" (Seschillie 2010). The filmmakers never receive specific details about the evaluation process, so they can only read between the lines when considering the other work accepted for the festivals. Specific selection criteria at all the festivals - from the 
ones in San Francisco, Santa Fe, Toronto, and the Smithsonian - are nonexistent and filmmakers are judged in certain generic categories and on quality alone, although the Smithsonian Native American Film + Video Biennale has a roster of categories that must be checked, presumably to help organise programming. But, one wonders how it might set some implicit standards: filmmakers must not be Native, the films must have a "Native vision" and be produced in North, Central, and South America and Hawai'i. Three major subjects must also be chosen and they include such categories as Activism, Sovereignty, Water Rights, Health, Environment, Urban Life, Community, Traditional Values, Cultural Preservation, Reservation Life, Substance Abuse, Language, Love, Humor/Irony, and Identity, among many other topics, many of which might be hard to apply to a film such as Rocket Boy.

Rocket Boy is an elegiac film, in the vein of Steven Spielberg's E.T. (1982), focusing on the power of the imagination when fueled by need and desire. It does not connect in any obvious ways to Deidra's outline of her political aims as a filmmaker. It originated in an earlier short film titled Imagine (2007) and focused on the freedom and empowerment that come from creativity, and in this way, perhaps a link can be made to Deidra's characterisation of her filmmaking interests. The film's narrative follows the plans of an 8-year old boy, Calvin, and his quest to build a rocket to reunite with his long-gone father. The fifteen-minute short features minimal dialogue. We hear Calvin's mother attempting to rationalise with him and remind him that his father is deceased, and, through an imagined flashback, we hear Calvin's father say goodbye to his infant son. Calvin himself utters only one line, "I just want to be happy."

The movie opens with a shot of foil-covered stars dangling from a ceiling slowly transitioning to an unknown figure, masked by a space 
helmet, staring out of a window. Viewers follow him as he soon thereafter races his bike through a generic, but upper-middle-class subdivision, with lush manicured lawns and irrigation sprinklers. The smooth, expert riding matches the soundtrack - an original song commissioned by the filmmakers (which cost the bulk of the film's $\$ 600$ budget). A pensive, tonally upbeat melody featuring piano and violin, builds some tension, but mainly establishes a mysterious, but positive mood. The idyllic, peaceful suburban landscape is further reinforced by the camera's framing of the protagonist by the arced jets of lawn sprinklers irrigating lush green lawns. There is nothing interrupting the protagonist's ride as he glides effortlessly, yet with purpose, through the winding, traffic-less streets.

After this initial scene, we see the protagonist, still clad in a helmet, enter his house and climb the stairs. As he walks toward the camera, just as he removes his helmet, the camera blurs his face in the background to sharpen the focus on a hanging foil star in the foreground. As he moves closer to the star, his face comes into focus. It's not until almost five minutes in that viewers see Calvin's unobstructed face, his father and mother, and then potentially identify the characters as Native. I draw attention to the filmmakers' clear interests in eschewing what might be considered familiar filmic markers of Indigeneity in the first five minutes of this 15-minute film. This is especially the case in the context of U.S.-produced movies featuring Native people. They are usually set on reservations, where familiar, often rural landscapes provide context and narrative foreground and background. This film is set in a new subdivision with homes typically recognised as upper-middle class. But, how can I say that this film is not marked by other markers of indigeneity? An observant viewer familiar with tribally connected surnames in the Southwestern United States, of course, would have noted the surnames of many of those involved in the making of the film. Thus, 
the title script, the printed word itself, would inscribe Native people as the producers, cinematographers, editors, directors, and screenwriters accountable for the film's creation and existence. Further conditioning most viewers' reception of the film would be the context of its showing/viewing. Film festivals, workshops, prize committees, even informal showings by filmmakers, all announce its status as a film made by Navajo and Navajo-Hopi individuals. I mention these facets to suggest a "re-framing" of indigeneity, a claim of Indigeneity that operates through refusal and a distancing from prior modes. This is true in terms of the setting in the subdivision as well and makes a profound claim though only indirectly: Native people are everywhere, Native people, at least these characters, live in new homes. How or why the mother and son live there is not the question (though apparently some festival-goers had questions about whether or not any of the filmmakers lived there). In sum, the erasure or elimination of older, stereotypical filmic references allows a new form of Indigeneity to emerge.

Returning to this initial "reveal" of Calvin's face, as soon as we see the dissolve-focus associating Calvin and stars, the camera offers viewers an extreme close-up of his brown pupil. A subjective shot of the closeup eye switches to an aluminum foiled star dangling from the ceiling followed by a fade to black. Calvin's view of the stars transitions us to a memory: silence and darkness dissolves to a twilight or dawn-lit scene where we see a man holding an infant in front of what looks like the very same window viewers first saw the protagonist staring out. "Calvin, I love you so much son. But I can't take care of you... I can't offer you the life your mother wanted, but I want a better life for you. I'll always love you son, and I'll always be there for you. Remember me" (Shimasani 2008). A zoom-in shot shows the infant Calvin alone, in close-up. 
This close-up is matched by a medium close-up of a woman, whom viewers presume to be Calvin's mother. Troubled and saddened, she burns a photograph of this same man, an act which can have multiple meanings, as the backstory is only indirectly revealed through the tension between the mother and son regarding his memories perhaps imaginative inventions - and her knowledge of Calvin's real father. This scene with the mother transitions to an exquisitely shot scene - in terms of lighting and detail - in Calvin's room where viewers see photographs of Calvin's father attached to foil stars hanging from his ceiling. The camera scans a wall filled with intricate drawings and a child's blueprints for building a rocket ship. Calvin sleeps surrounded by this mythic dream of space travel and the myth he has constructed about his lost father.

In the next scene - in his dream, the next morning - he dons his space suit worn during the opening sequence, grabs a photograph of his father, and uncovers something in his garage. In darkness, Calvin enters, flips a switch and viewers see before him a lit up control panel with a start-switch for which we had previously seen designs in the boy's room. On the video monitor, viewers see images of his missing father as if the machine has been programmed to locate him. This moment of magical wonder is interrupted by Calvin's flashback of his mother. In close-up, as if she were sitting across from her son at the kitchen table, his mother says, rather harshly, "You're trying to say you want to leave me? That's not gonna happen, you want to know why? Cuz your dad's dead. That's why. What makes you think he'll come back anyway?" To which Calvin responds, "I just want you to be happy." "We're not always happy, Calvin. We pretend to be. That's what you're doing. Nothing else," his mother responds. This realitycheck is furthered in the subsequent scene - still in flashback, presumably - when viewers see Calvin in his room, sketching plans, looking at his father in wrinkled, perhaps recovered, photographs. In 
voiceover we hear his mother telling him, "Put those away, I don't want to see them again." In a transition to another brief memory we hear Calvin's mother try to use some of his reasoning about space travel: "Once you're in space, I won't be there to protect you, will I. Do you see me? I'm the light. And your father is the darkness." She's gentle, yet firm. In the subsequent segment we see the mother's private anguish in her bedroom, later transformed into love and care when she enters Calvin's room and tenderly caresses her son's head and back.

An image of a foil-covered star brings viewers back to scene with Calvin in his rocket ship. He presses the launch button and viewers see the control board light up, rumble, and we see a montage of images of father and infant. The instrumental soundtrack crescendos, intensifying the mood, and then it calms down and the camera zooms in on a photograph, blocking out the shaking wires, control panels, and most of the flashing lights. Viewers see an empty cockpit and a lone photograph of a grinning man looking down at his infant. This shot dissolves into blackness and then transitions to an abstract scene of lightness where slowly, incredibly slowly, viewers see a foil star come into focus, something Calvin had looked at everyday alongside his rocket designs. The credits roll after the star fades to black. The deliberate ambiguity and refusal of closure underscores the sophisticated storytelling at work in this film. Perhaps Calvin has found, through ingenuity, the means to recover his lost father, perhaps Calvin hangs on to false versions of his past, illusions that will jeopardise him in the future, perhaps Calvin learns the hard lesson that his desires and dreams can't alter the past and decisions made by adults.

In general, the three partners of Paper Rocket Productions feel little obligation to fulfill audience expectations, though they expect to be 
confronted with questions about theme and subject matter as it intersects with their subject positions. Some readings are shrugged off. As Jake says, "Take what you want. I guess I think if you don't like something, then so be it. I can't change you or what you expect." While some comments are given serious thought: "One older man at our New York City screening [of Rocket Boy] said that film's theme was clearly Native American since it is fundamentally about loss." Donovan, Rocket Boy's director told me, “That's interesting. I hadn't thought of that before." When pressed, neither Donovan, Deidra, nor Jake would necessarily say they bought that notion, but were intrigued that this viewer found that particular meaning. Rather than validate this or other interpretations, each would rather talk about how the film exhibits their technical skill. Deidra has grown more confident about editing and tone, Donovan is proud of camera composition and lighting and the way "still, very subtle movements amplify[ied] emotion," and Jake speaks about the intersection of set building, realism, and the visual artifice of cinematography (Seschillie 2010).

Does an analysis of this film - or their technical commentary on their experiences - help us figure out how the filmmakers are negotiating indigenous identity? It does insofar as it stakes a claim for the sovereignty of the imagination, of the right to tell any story, in the way it resists the codified notions (especially in film and much scholarship) that culture and indigeneity is unchanging and uniform, if not univocal in its expressive vision. In this regard, culture in the guise of tradition or traditionalism can become a limiting and a predictable force in determining so-called authentic versions of representing, embodying, and realising Indigeneity. In fact, as Martin Nakata points out, "As the central representational element, culture has a constitution with acceptable/unacceptable definitions that provide the State a standard/norm to either reward or penalise. Furthermore, culture is important for the State because it sets up a public knowledge 
where individuals may self-regulate their own behaviours (e.g., internalising culture as a the rudimentary premise for viewing and solving problems)" (1993, 343).

How does this affect the creative vision of filmmakers? Well, if "Culture" or "Traditionalism" become determining factors in developing narratives, themes, and perspectives for film projects, and if static notions of culture and tradition are the guides, albeit developed by non-indigenous peoples, then the products are not necessarily free expressions of indigenous identity and vision, but recapitulations to settler colonialist social vision. Much of this linkage between indigene and Native is directed from the field of colonial power, but potentially, if not inevitably, becomes an internalised controlling legacy difficult to break. And the process is recursive. Marcia Langton, in an essay on Indigenous Australian film and art, notes, that, in fact:

"Aboriginality," therefore is a field of intersubjectivity in that it is remade over and over again in a process of dialogue, of imagination, of representation, and interpretation. Both Aboriginal and nonAboriginal people create "Aboriginalities," so that, in the infinite array of intercultural experiences, there might be said to be three broad categories of cultural and textual construction of "Aboriginality": first, that emerging from closed, Aboriginal-only social situations; second, the creation of "Aboriginal" stereotypes, iconography, and mythologies established by Anglo-Australians with no dialogue with Indigenous Australians; and third, those notions growing out of "actual dialogues between Aboriginal and non-Aboriginal people" $(2003,120)$.

Well-known Spokane/Coeur d'Alene author, puts it more colloquially, "In my dictionary, 'Indian' and 'nostalgic' are synonyms" (Thiel 2004). For Alexie this explains why non-Native people continue to be racist, ignorant, and naïve about contemporary indigenous people. But 
Alexie continues, further suggesting the nostalgic underpinnings of internalised colonialism: "As colonized people, I think we're always looking to the past for some real and imaginary sense of purity and authenticity" (Thiel 2004).

Rocket Boy refuses this nostalgia - as does Real Love - and instantiates the very sort of inter-subjective dialogues Langton refers to that might bring all of us to new understandings of nascent, emerging, and vibrant Indigeneities. And, while Shimasani honors her grandmother's culture, the filmmaker never once holds it as the model she must emulate. Hip filmmaker that Deidra Peaches is, you would never mistake her love and admiration for her grandmother for her wish to be her grandma, or her sense of obligation to be like her. Quite the opposite. So, the value of a film such as Rocket Boy is also this: that it stands alongside other works by the very same filmmakers as potential disruptions of a long circuit of expectations, including those that film festival boards might uphold. Ultimately, Deidra and her partners recognise that the real key to building an audience base, particularly a Native or Diné audience base rests in refusing to recapitulate to nostalgic portraits of capital - C "culture," culture as it has been used to control, culture as it has been internalised to regulate. When asked how a larger and younger audience base can be fostered, rather than looking for more support from the Navajo Nation - as suggested by one scholar ${ }^{67}$ - Deidra puts the onus on filmmakers,

\footnotetext{
${ }^{67}$ Lewis suggests this body of film will only flourish if a local audience base is developed and he suggests the Navajo Nation itself make a greater effort to support filmmaking initiatives. Taking his theoretical cues from postcolonial interrogations of nationalism, but acknowledging the power of the formation of national canons of film, Lewis simplistically summarises commonalities among all of the films, laying out, I would argue, problematically, a superstructure for anything identified as Navajo film: "Again and again, as I watched these often hard-to-find titles, I saw filmmakers commenting on the preservation or
} 
thinking that the Nation would be its own regulatory force dictating its vision of culturally relevant narratives: "I think there's no appeal for the younger generation in these stories. It's all traditional based, based on tradition and culture. In order to create a film, it needs to be based on the youth. Even the water rights, they leave the youth out, leave us out. If you want to make a successful film, you need to bring in the youth." Don jumps in, "Yeah, if you shove traditional things, people may shut down." To which Deidra responds with laughter, "I see movies to get away from all that..." (Seschillie 2010).

\section{References}

Benally, K. and S. Ray. Visit to Jeff Berglund's English 345 class, Northern Arizona University. 2 Feb. 2009.

Deger, J. Shimmering Screens: Making Media in an Aboriginal Community. Minneapolis, University of Minnesota Press, 2006.

Emerson, R and M. Henry, et al. 'New Mexico Filmmakers: A Roundtable.' Native American Literature Symposium. Isleta Pueblo, New Mexico. 18 Mar. 2011.

Horse You See. Dir. Melissa Henry. Red Ant Films, 2007. Film. Imagine. Dir. Deidra Peaches. 2007. Film.

restoration of familial ties, cultural continuity, Native language, individual wellness, and tribal land. The last is crucial--as descendants of a dispossessed people (at least for portions of their history), Navajo filmmakers are understandably concerned with the politics of geography. Many of them have demonstrated a powerful awareness of their ancestral landscape and use its unique features as vital elements in their work. Similarly, many of them share an emphasis on negotiating past and present, tradition and modernity, in a manner that pushes them toward narratives of homecoming, some successful, some not" (53). 
In the Footsteps of Yellow Woman. Dir. Camille Manybeads Tso. 2009. Film.

Langton, M. 'Aboriginal Art and Film: The Politics Of Representation.' In Blacklines: Contemporary Critical Writing by Indigenous Australians, edited by Michele Grossman. Carlton: Melbourne UP, 2003.

Lewis, R. 'The New Navajo Cinema: Cinema and Nation in the Indigenous Southwest.' The Velvet Light Trap 66 (2010): 5061.

Longhouse Media. Accessed $31 \quad$ Oct. 2011. http://www.longhousemedia.org/.

Nakata, M. 'Culture in Education: For Us or for Them?' Eds. N. Loos \& T. Osanai. Indigenous Minorities and Education: Australian and Japanese Perspectives of Their Indigenous Peoples, the Ainu, Aborigines and Torres Strait Islanders. Tokyo: San-YouSha, 1993. 334-349.

Navajo Talking Picture. Dir. Arlene Bowman. 1985.

Outta Your Backpack Media. Accessed 31 Oct. 2011. http://oybm.org/. Real Love. Dir. Donavan Seschillie and Deidra Peaches. 2007. Film.

Rocket Boy. Dir. Donavan Seschillie. Paper Rocket Productions, 2010. Film.

Seschillie, D., Peaches, D. and J. Hoyungowa. Personal interview. 11 Oct. 2010.

Shimásání. Dir. Blackhorse Lowe. Másání. 2009. Film.

Shimasani. Dir. Deidra Peaches. 2008. Film.

Thiel, D. "A Conversation with Sherman Alexie.". Crossroads 61 (2004).

Accessed at http://www.poetrysociety.org/journal/articles/salexie.html Worth, S. and J. Adair. Through Navajo Eyes: An Exploration in Film Communication and Anthropology. Bloomington: Indiana University Press, 1972. 


\section{THE LIONS OF LESOIT: SHIFTING FRAMES OF PARAKUYO MAASAI INDIGENEITY}

\section{Kelly Askew and Rie Odgaard}

\section{Battling Lions}

As dusk fell on April 10 ${ }^{\text {th }}, 2012$, an unlucky cow in the village of Lesoit, on the Maasai Steppe of central Tanzania, met its death in the jaws of a lion. ${ }^{68}$ This was the seventh cow (plus one donkey) to meet this fate - a rash of killings that began in March the previous year. Located at some distance from the national parks where prides of lions wander freely, suffering little but boredom and incessant gawking from tourists, Lesoit had not faced lion attacks in some seventeen years. Over the course of the year that these killings occurred, a deepening existential crisis beset this Parakuyo Maasai community, for if there are two things that Maasai are famous for, it is protecting their cattle and killing lions.

Parakuyo tradition holds that when a lion attacks, a series of traps are set near the carcass and a lion blind (a shelter for concealing hunters) is dug out in the earth, expertly camouflaged by branches, packed soil

\footnotetext{
${ }^{68}$ Research in Lesoit village, Kiteto District, Manyara Region was undertaken by an international and interdisciplinary team of scholars from May 2010 to July 2012 funded by the National Science Foundation (NSF). Team members: K. Askew, R. Odgaard, F. Maganga, H. Stein, L. Nyeme, E. Sulle, K. Owens, V. Makota, C. Ndomba, S. Gerald, R. Mangilima. In May 2011, with funding from the Mellon Foundation, K. Askew, F. Maganga and L. Nyeme returned to Lesoit with two filmmakers P. Biella and I. Drufovka at village chairman F. Kaipai's request. The participation of all and funding from NSF and Mellon is gratefully acknowledged.
} 
and logs. Three - not two, not four - warriors (ilmurran) occupy the blind (oltapit) for as many nights as necessary until the lion is killed or has clearly moved on with no intent of return. Lions are known to hunt in the early evening, so with each of these attacks, oltapit were duly constructed and Lesoit's brave ilmurran argued over who would be given the privilege of occupying it to await the lion's return. And yet, attack after attack, the ilmurran remained empty-handed.

After the sixth cow had been lost, Lesoit's leaders deemed that a cultural intervention was necessary. They decided to organise exuberant celebrations called Eng'ilakinot that honor lion-killers following a successful kill, overlooking the fact that the lion had yet to be killed. They hoped that by honoring lion-killers still alive in the community, it would inspire the ilmurran that they, too, could attain such fame and honor. But this celebration would include a pedagogical component not found in a typical eng'ilakinot. Village leaders approached a famed lion-killer named Kunando Nyorei and asked him to oversee the building of two mock oltapit by the ilmurran that would be subjected to his supervision and critique. They decided, moreover, that the ilmurran would prepare themselves just as they normally would in advance of a lion hunt by eating only meat roasted in a secluded camp (orlpul) and by consuming traditional medicines that confer bravery and remove all fear (kiloriti and muktan). They would then occupy the blinds and face Kunando's criticism of the construction of their blinds, their stance and conduct within them, the placement of their weapons, placement of their bait and their endurance.

These changes to tradition met no resistance from Lesoit elders. They, too, worried that their warriors had somehow lost the knack of lion killing. And some feared that their culture was in arrears due to increasing numbers of Lesoit warriors migrating to Zanzibar to earn 
cash working as night watchmen and for the chance to land a European girlfriend. Meiu (2009) has described a related phenomenon of Samburu pastoralists from northern Kenya traveling to the coastal city of Mombasa to find European girlfriends and the material advantages such relationships confer. He writes, "In the 1980s... women from European countries (but also, to a lesser extent, from Australia, North America and Japan) began visiting Kenya armed with a clear image of the tall, slim bodies of the 'vanishing' Maasai morans (warriors), walking half-naked, covered only by their red shukas (body blankets) and proudly carrying their spears and clubs. In the early 1990s, Kenya emerged as yet another international sexual destination... its draw relied intensively on eroticised representations of the Maasai and Samburu" (Meiu 2009, 109). By far the most commercialised instance of this is the memoir Die weisse Massai ("The White Maasai”) by Corinne Hofmann (1998), a Swiss-German woman who on holiday in Mombasa found herself intensely attracted to a Samburu moran whom she married, had a child by, and ultimately left. It was made into a major motion picture in 2005 and spawned two sequels and a spot on the American show 60 Minutes. ${ }^{69}$

Currently in the village of Lesoit, with an adult male population of around 450, there are at least eight men that have ongoing, long-term, foreign girlfriends or wives and countless others who have had such relationships in the past, thanks to labor migration to Zanzibar. While eight may not sound significant, any interracial relationship in a rural Tanzanian village is remarkable, much less eight times over. Such transnational couplings draw significant attention. And, they often provide new sources of income, in addition to an exotic romance that inversely complements the desires and expectations discussed by

\footnotetext{
${ }^{69}$ Transcript available at:

http://sixtyminutes.ninemsn.com.au/stories/tarabrown/259465/meet-the-whitemasai.
} 
Partridge (2012) of German women in their relationships with African students and immigrants: an opportunity to travel and experience another culture while staying at home in Germany.

The area surrounding Lesoit bears witness to an earlier interracial relationship. Visit long enough and someone may point out to you the "Maasai Mzungu" ("European Maasai"), a man in his early forties born of an early cross cultural entanglement between a Maasai woman and a European man. ${ }^{70}$ You'll then likely be told in a triumphant tone of how he rejected his father's offer to move to Europe in favor of choosing his Maasai identity and remaining in the village to live a Maasai existence.

This essay explores some of the ways in which Parakuyu, a minority group among the Maa-speaking communities of East Africa known collectively as 'Maasai', perform Parakuyo indigeneity through cultural practices, narrative, song, poetry, and ritual. Not intended as a detailed analysis of Parakuyo cultural traditions, rather, our purpose is to examine how one Parakuyo community deploys their traditions as tools for confronting contemporary challenges, readily modifying them as needed. Marginalised both in respect to other Maasai communities and to the broader nation-state, and subject to endless incursions on their land by outsiders, this community is struggling to attain the promises of modernity while maintaining their distinctive sense of self. Not bound blindly to tradition, as some would have it, Parakuyu constantly innovate and develop new strategies for pursuing their economic, political and social goals. Thus, in contrast to popular

\footnotetext{
${ }^{70}$ There are varying stories circulating about this man's history. Some say his father was a priest. Others say he was Turkish and involved in the ivory trade. The common thread of something illicit--a noncelibate priest or trade in a banned item-is worth noting. It may serve as a coded metaphor for the social stigma accompanying interracial relationships in early postcolonial (1960s) Tanzania.
} 
depictions of culture as an obstacle to development, what we describe here is how this indigenous community actively taps their reservoir of tradition in their pursuit of development. Yet, their proud insistence on being identified as pastoralists with origins from distant places inadvertently, we argue, contributes to their economic and political marginalisation.

\section{Performing a Pedagogical Eng'ilakinot}

The same pride with which the story of the Maasai Mzungu is told was evident in abundance on June $1^{\text {st }}, 2011$ when Lesoit held its somewhat unconventional eng'ilakinot celebration. Earlier that year, the village chairman had approached one of the authors and asked if she could help them document an upcoming special event on film, as it was to be one that they wanted future generations to be able to see. Arrangements were duly undertaken and a small film crew arrived three weeks early to learn as much as they could before attempting to film what was described as a 'lion festival' (tamasha la simba in Kiswahili). ${ }^{71}$

Three days before the main event, and under the supervision of their age-grade leader and spokesman (a warrior assigned responsibility for (1) acquiring expertise from elders on all cultural matters pertaining to warriorhood, and (2) representing the warriors in village discussions), the warriors started digging their mock lion blind (oltapit). Two days later, they constructed a second oltapit in a different style: a more temporary - and considerably more dangerous blind constructed of branches and leaves. Anyone occupying such a blind faces great risk given that branches and leaves offer scarce

\footnotetext{
${ }^{71}$ The Chairman and the Lions, directed by Peter Biella and produced by Kelly Askew, an official selection of the 31st Jean Rouch International Film Festival, November 2012.
} 
protection from the strength of an attacking lion. Still, knowledge of how to quickly and skillfully erect such a blind in cases where a lion attacks late in the day (thus not allowing time for the digging of a subterranean oltapit) is valued knowledge. And, the fact that lions typically return to continue feeding from their kill presents an opportunity no warrior would want to miss.

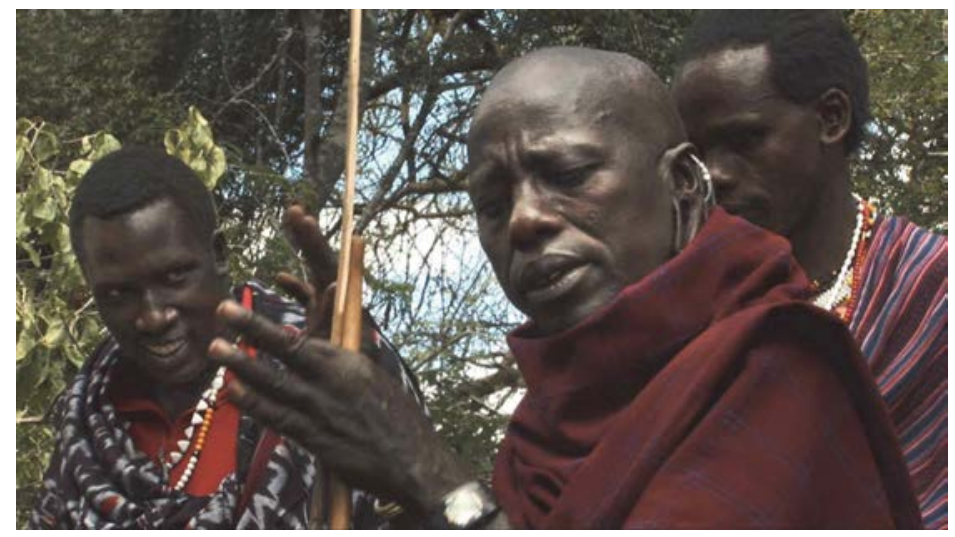

Photo 1 Lion-killer Kunando Nyorei offering comments with village chairman Frank Kaipai (left) looking on

On June $1^{\text {st }}$, famed lion-killer Kunando Nyorei gathered with a small group of elders to judge the efforts of the warriors and their enactment of how they would behave when occupying an oltapit. First, Kunando evaluated the underground oltapit, an impressively unobtrusive lump in the landscape that housed three armed warriors, each with his weapon pointed at a different piece of imaginary bait set out in three spots (to the right, to the left and in front of the opening to the oltapit). After Kunando was satisfied that they had assumed and sustained correct positions and evinced the desired single-mindedness of purpose required of a successful lion-killer whose eyes must never stray from his assigned piece of bait, he indicated that they could exit 
the oltapit. As they climbed out, one warrior was chastised for wearing sunglasses, which he removed with haste: "You went in there with your sunglasses! What's wrong with you?" asked an elder. "Did you come here to look beautiful? Take those glasses off!"

The second oltapit appeared to an unknowing eye to be but a bush. A tall bush, perhaps, but a bush nonetheless. Yet upon close inspection, one could identify the tip of an arrow, the point of a spear, and the barrel of a rifle protruding from the leafy branches, again with each aimed in a different direction. Kunando and the elders commenced discussion of the merits of this "emergency" oltapit and the dangers of occupying it. Other warriors were gathered nearby to watch the evaluation of their comrades and to listen to what Kunando had to say. One now hesitantly asked if use of a flashlight was allowed at night. Vehemently, Kunando replied:

"Absolutely not! You cannot turn on a flashlight because if you are in a blind you cannot even swallow your own saliva because if you swallow the lion will hear it. And if you scratch yourself, the lion will hear it. So if you are inside this you must be like the dead. There is even a special way of breathing... There's no talking or shifting position. You must be still like a corpse until you kill the lion."

Now in the case of an actual lion kill, the first warrior to deal the lion a fatal blow (be it with spear, arrow or rifle, the latter being a slightly less admirable weapon) is honored as a hero and affixes to his spear the trophy of the lion's tail to publicise his feat of courage. Since warriors typically hunt in a group, the warrior who delivered the second fatal blow attaches part of the lion's left paw to his spear, indexing his secondary hero status. Going into this enactment of hunting procedure, the warriors had selected from among their ranks two warriors whom they decided best exemplified the ideals of concentration, determination, bravery and endurance. Lacking lion 
parts to signify their selection as the festival's heroes, both were anointed with red ochre and the warrior selected to be the primary hero was adorned with a special headdress that framed his face with black and white colobus fur (aesthetically recalling the mane of a lion). The secondary hero was given an iron leg bell tied just above his right knee, and both he and the second hero were directed to pose for our cameras with colorful shields that had been specially commissioned for this eng'ilakinot featuring a painted lion and the phrase "Maasai Lesoit Village."

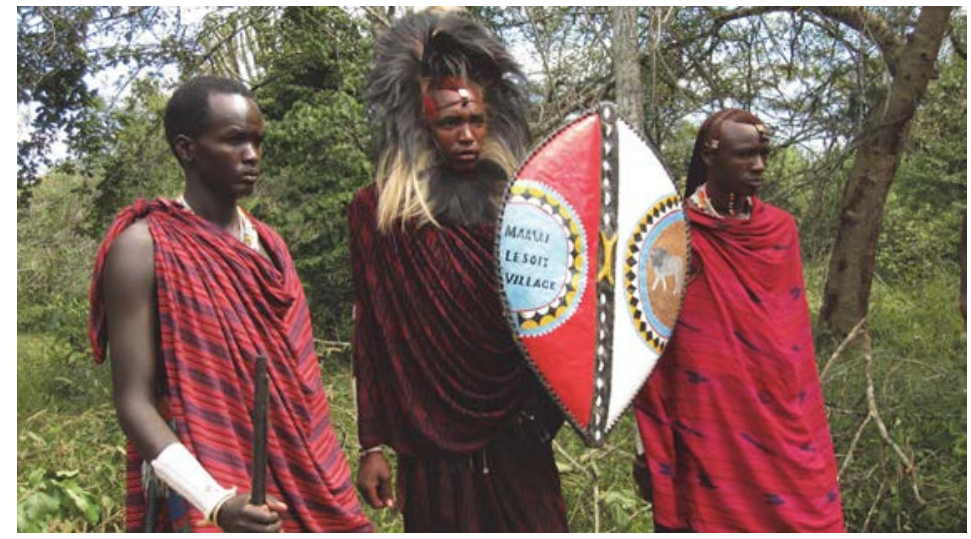

Photo 2 Primary hero with black and white colobus headdress and shield. Photo credit: K. Askew

With the oltapit evaluations complete, the warriors disappeared. To ensure that people would turn out in large numbers to complete the celebratory component of this performed eng'ilakinot, but also to maximise expenditures, the village leaders opted to pair it with an actual celebratory event. A ritual called olorbak binds two men who 


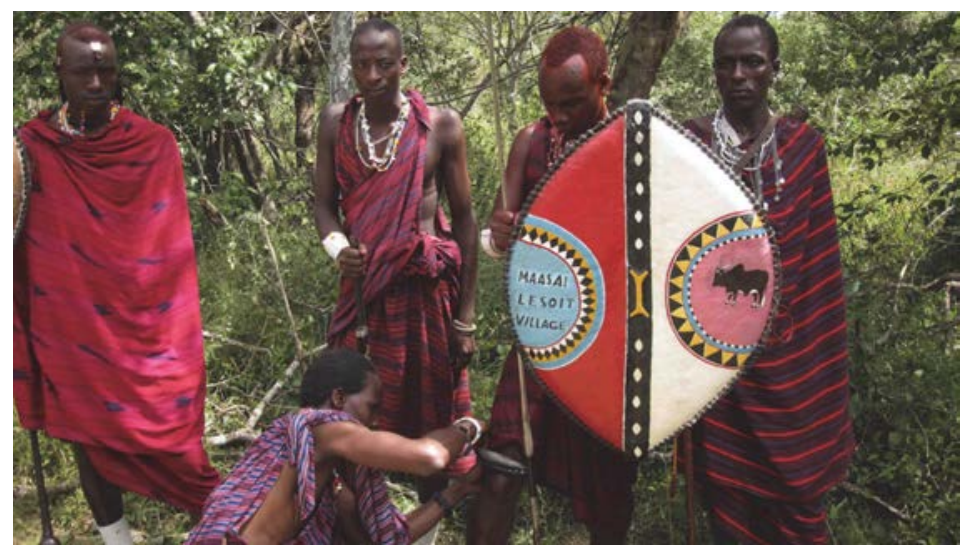

Photo 3 Secondary hero with bell being attached to his leg by fellow warrior. Photo credit: K. Askew

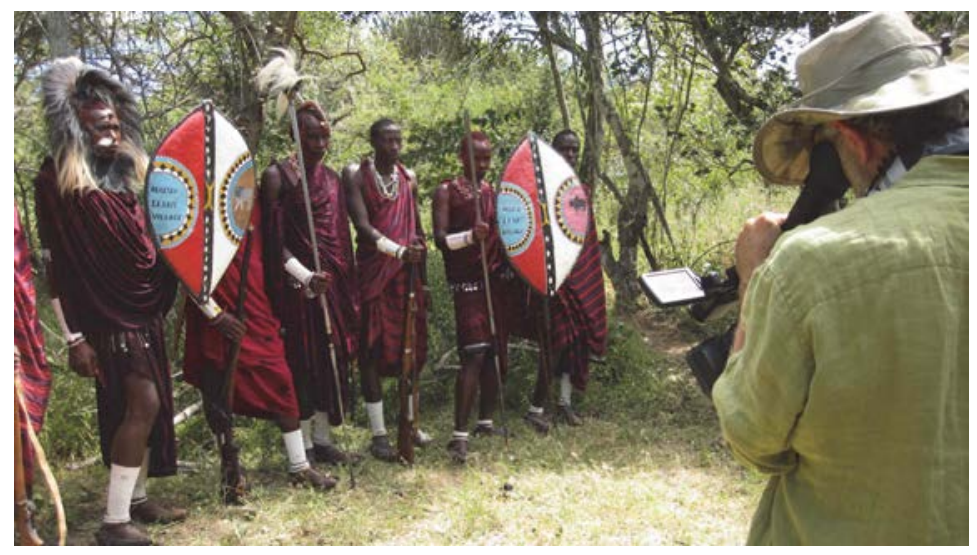

Photo 4 Posing for director Peter Biella's camera. Photo credit: K. Askew

have "retired" from warrior status as blood brothers for life. It also reunites the warriors from their cohort, who come to witness this ritual, and sing, feast and reminisce about their warrior days late into the night and throughout the following day. Feasting, dancing, and singing also characterise eng'ilakinot festivities. Thus, song served as 
the transition linking the two celebrations. Silently processing singlefile towards the celebration site, the warriors reappeared with the primary hero leading the procession. At punctuated intervals, other warriors would in turn suddenly exit the line to run ahead and shout out formulaic texts honoring their ties to the land, their deep knowledge of the land and lions, and their bravery:

My father, my father

I wasn't late but the trip was long

Serai! Serai! Serai! ${ }^{72}$

I wasn't late to arrive at my Serai grasslands

It's only that the trip is long

I wasn't late

The lion cannot deceive me there in my grassland

Where the warriors make camp and eat meat

Serai! Serai! Serai!

Serai my father is a narrow river

Praise my arm that bears this heavy shield!

Praise my arm that bears this heavy shield!

My father, I wasn't late but the trip was long

My father, I call upon you when I am as fierce as fire

My father, I wasn't late but the trip was long

My father! My father! My father!

Serai! Serai!

My Serai grassland, your warriors are as fierce as fire!

Mtambalo valley with the narrow stream

Serai, where the lion dances with its flowing mane

Mtambalo! Kibaya!

My Serai grassland, your warriors are as fierce as fire!

Lion, you cannot deceive me there.

Serai! Serai! Serai!

${ }^{72}$ Serai is the name of an area near Lesoit teeming with wildlife. 
The warriors processed until they reached the cattle kraal, which they entered to form a large semi-circle. Three warriors overcome by emotion and the effects of the afore-mentioned traditional medicines consumed in large quantities to stave off fear and enhance ferocity, entered a trance and lunged headfirst into the thorn enclosures walling the kraal. They had to be extracted and handled gently by fellow warriors until they returned to consciousness. Had one veered toward judging this eng'ilakinot 'inauthentic' due to lack of a dead lion, the actions of these warriors would have dispelled it. Their immunity to puncture wounds, their extreme agitation and their unnatural strength (each requiring three warriors to successfully restrain them) exposed altered states of being. Performativity replaced performance. The other warriors, however, acted as though nothing were amiss and continued to process solemnly into the center of the kraal, until their horseshoe formation was complete and the singing could commence.

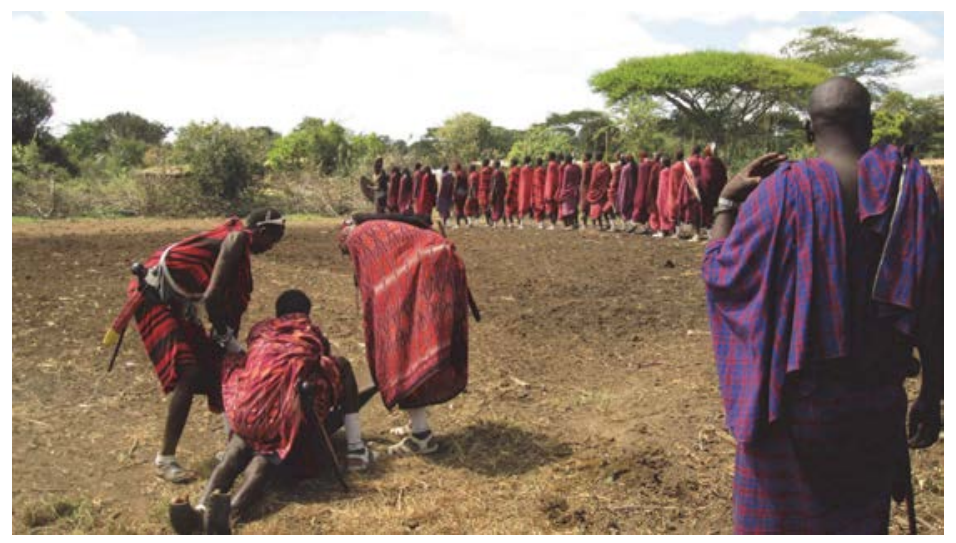

Photo 5 Warriors preparing to sing with collapsed warrior restrained by others in foreground. Photo credit: K. Askew 
In normal circumstances, such a formation would have immediately drawn a counter formation of young girls who would dance opposite from and sing in counterpoint to the warriors. This being a pedagogical eng'ilakinot, however, the maidens didn't appear until the olorbak festivities kicked in later on. Instead the warriors sang a series of three songs, all of them having to do with protecting cattle and hunting lions. One was entitled Emburkoi:

Eepi iyok iremeta nejulo tolonyoke kimbokie Olesiria opi ingiri olng'atuny

Simanjiro aii nakinya kimbokie olouwaru engaina enanga

Ipuko ilouwarak tengorongoro neyok nado ilong'oi naipukie

Olentaparri tolodo murrutot kidaraki tolndwalan ingitung'ati ejore
Our weapons are sharp and have mixed with the blood of the lion. The hero from Olesiria clan battled many lions.

On our Simanjiro grasslands we stopped the lion by distracting it with our robes.

The lion ran away from Ngorongoro because of our heroes with their red shields. Yes, it ran away.

In the red ravine, Olentaparri showed off his heroism in battle by sounding his leg bells.

With their special repertoire of songs about bravery and the need to outwit their adversaries, whether lions or cattle rustlers, the ilmurran exuberantly performed their youthful vigor. They leapt high into the air, individually taking turns to rush suddenly into the middle of the circle towards onlookers, where young maidens rather than a film crew would ordinarily be. Some would leap solo, others would swing long braids about in a whirl of motion. And, underlying the songs, 
sounded a guttural ostinato chant -part human, part lion - acoustically uniting warriors with their foe.

These trajectories, of traditions undergoing intentional modification and of transnational yearnings, represent some of the realities of contemporary Parakuyo communities. These communities certainly vary greatly in their performance of indigeneity to foreigners, to the state, to neighboring communities and to themselves. In Zanzibar, migrant warriors perform a version of Maasai-ness carefully designed to appeal to tourists, especially those of the female sex. ${ }^{73}$ Yet in this remote corner of the former colonial Maasai Reserve, away from the gaze of tourists and government officials, this one Parakuyo community proudly performed their Parakuyo-ness, their modified eng'ilakinot, for themselves, their neighbors, and an invited film crew. And, in doing so, they also affirmed their identity as pastoralists (in singing of defeating lions that attack their cattle), their identity as Maasai (proudly proclaimed on their commissioned shields), and their ties to, and deep knowledge of, their land (via the poetic texts identifying elements of the landscape known to the community and valued especially by the warriors). This cultural intervention served its intended purpose. One year and eight victimised livestock later, the ilmurran succeeded in killing their lion.

\section{Parakuyo/Maasai Indigeneity}

Parakuyo communities are marginalised several times over. They are numerically disadvantaged relative to the dominant Kisongo Maasai, who live in and around the tourist centers of Arusha, Ngorongoro, and Nairobi. Perhaps the most dominant section (iloshon) of the

\footnotetext{
${ }^{73}$ For a comparable Kenyan case, see Bruner and Kirshenblatt-Gimblett 1994.
} 
Maasai complex, ${ }^{74}$ the Kisongo in the late $19^{\text {th }}$ century waged war against the Parakuyo in the famed Iloikop Wars (Beidelman 1960; Berntsen 1979; Galaty 1993; Jennings 2005a, 2005b; Waller 1978; Weatherby 1967) and nearly succeeded in eradicating Parakuyo altogether. Kisongo is the section of Maasai that, historically, has had better access to education and been able to attract international funding. They therefore have received greater attention globally, both as featured exotica in Nike, American Express, high fashion and mobile phone advertising campaigns, as well as in international political forums aimed at protecting the rights of indigenous peoples. They are identifiable visually through their highly colorful beadwork (as opposed to the Parakuyo preference for mostly white beadwork), different styles of head ornamentation, and the cloths preferred by women: aurally through dialectical differences, and spatially through their contiguous territorial homeland spanning northern Tanzania and southern Kenya.

It was a Kisongo Maasai, Moringe ole Parkipuny, who, in 1989, first attended the United Nations Working Group on Indigenous Populations (see Hodgson 2009, 2011; Dahl 2012) to lay claim for an African presence in that august entity. Through Maasai mobilisation efforts and the support of some international associations, ${ }^{75}$ the United Nations Working Group for Indigenous Populations (UNWGIP) belatedly accepted African communities (Maasai, Pygmy, San, Berbers, Amazigh and others) within their mandate. In this

\footnotetext{
${ }^{74}$ There is no scholarly or Maasai agreement on how many sections of Maaspeaking peoples there are, but the most commonly cited are: Kisongo, Siringet, Salei, Purko, Matapato, Loitai, Laitayiok, Kaputiei, Uasin-Kishu, Siria, Raal, Samburu, Arusha and Parakuyo. See Kipury 1983; Spear and Waller 1993. ${ }^{75}$ Most significantly the Denmark-based International Working Group for Indigenous Affairs (IWGIA).
} 


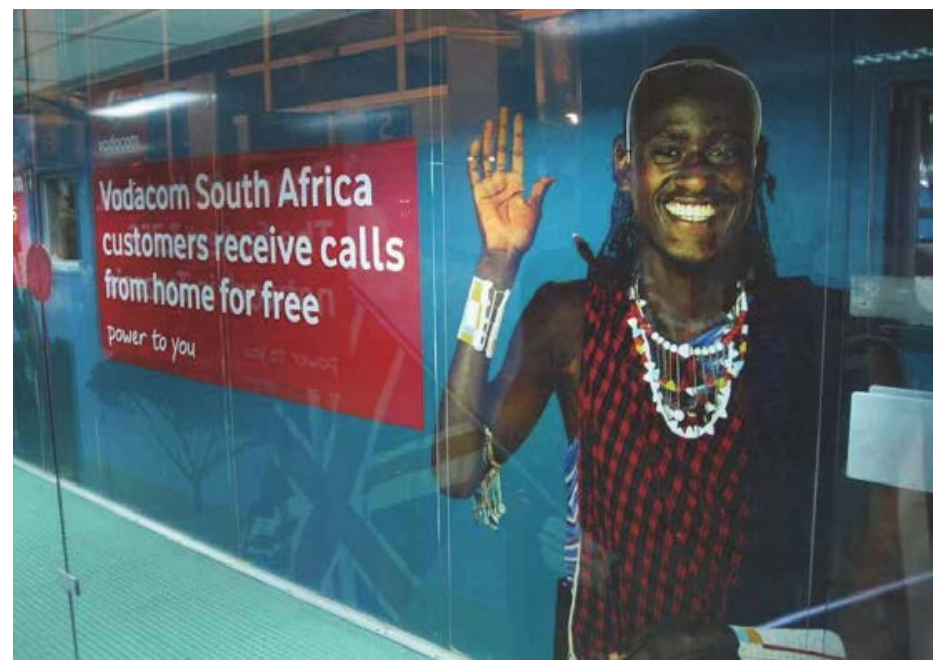

Photo 6 Mobile telephone advertisement one sees upon arrival in the Dares Salaam airport. Photo credit K. Askew

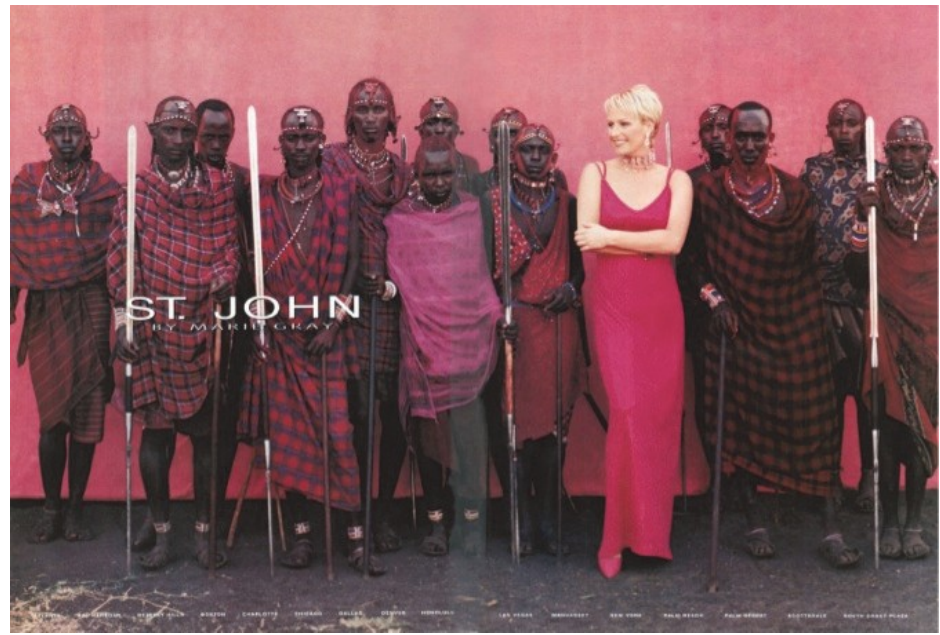

Photo 7 Fashion designer advertisement 


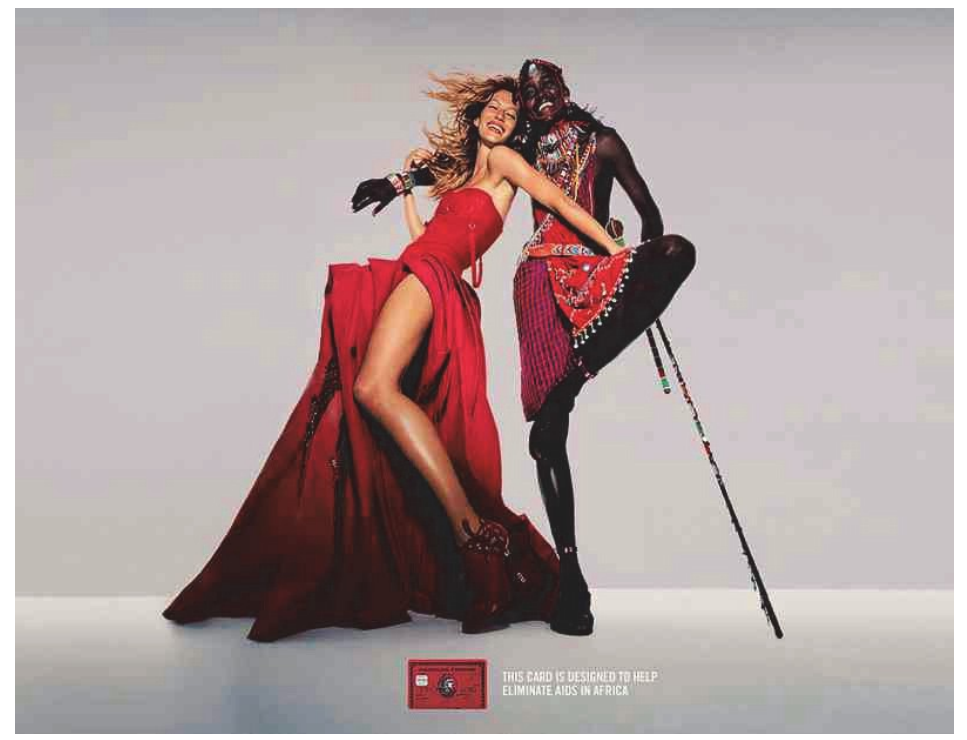

Photo 8 American Express advertisement featuring an eroticised white female-Maasai warrior relationship

context, "indigenous" is defined not in terms of place of origin (Maasai being no more or less "indigenous" to Africa than, say, Yoruba or Luo people) but by the vulnerability and marginal position of their way of life in the face of state policies of neglect or outright oppression. Thus, in international arenas, "indigenous" populations are those who "struggle for rights being denied them" (Dahl 2012, 189), and in East Africa, it is pastoralist (e.g., Maasai, Barabaig, Turkana, Rendille, Samburu) and hunter-gatherer groups (e.g., Akie, Sandawe, Hadzabe, Borani, Okiek) who self-identify as such.

Despite there being many sections of Maasai, Maasai are frequently reduced to Kisongo-ness. Indeed, some scholars even refer to Parakuyo as being outside the Maasai complex, granting Parakuyo (or 
'Kwavi' or 'Humba,' both derogatory terms applied to Parakuyo) separate ethnic status even though they share a common language Maa - and common dependence on pastoralism with the other Maasai sections. Beidelman, for instance, noted:

Much of the confusion in the various historical sources and in Government reports dealing with Masai and related groups lies in the indiscriminate application of the terms 'Masai' and 'Kwavi' to any Masai-type people. Usually 'Masai' is reserved for those who appear to fill the classic Masai stereotype of the observer and 'Kwavi' is applied to those people who do not quite fit this stereotype but who speak languages similar to Masai, such as Arusha, Meru, Baraguyu, Taveta, Njemps, etc. Often 'Kwavi' merely refers to any Masai-like group observed tilling land. (Beidelman 1960, 246, cited in Maganga et al 2007)

Parakuyo today are dispersed over a wide geographic span stretching from coastal Tanzania (Tanga, Bagamoyo, Kilwa) across the central plain (Morogoro, Kiteto) to the Southern Highlands (Iringa, Mbeya), leading one scholar to call them the "Scatterlings of East Africa" (Jennings 2005a). This is due in part to the conflicts with the Kisongo and in part to their active search for ever-shrinking grazing land and greater economic opportunities. And, like all pastoralist and huntergather communities, they suffer the disdain of the majority of Bantu farmers (who view their claims to land as suspect), and they suffer open discrimination from the national government. Recent statistics indicate that Tanzanian pastoralists currently number around 1.5 million (in a total Tanzanian population of around 40 million) and contribute at least $30 \%$ of the agricultural GDP, producing some $90 \%$ of meat and milk products (de Jode and Hesse 2011: 9). Yet, despite making critical contributions to national economic growth, pastoralists in Tanzania are consistently discriminated against and denied basic human rights. 
Pastoralism as a way of life is popularly viewed as incompatible with modern development goals and in need of eradication. Indeed, the current president of Tanzania, Jakaya Mrisho Kikwete, in his opening speech to Parliament on December 30, 2005, insisted:

Mr. Speaker, we must modernise animal husbandry. We will have no alternative. We must abandon altogether nomadic pastoralism which makes the whole country pastureland.... The cattle are boney and the pastoralists are skeletons. We cannot move forward with this type of pastoralism in the twenty first century (cited in ole Ndaskoi 2009, 3).

It is a sentiment one finds echoed in other mass-mediated formats, such as newspaper editorials:

Why does it seem that livestock keepers never do something, anything, to minimise their losses through drought and, instead, practically sit on their hands, watching their herds die off as a matter of course? I mean, for example, why do they not sell them off when the going is still good? (The Citizen, 14 September 2011).

One scholar, an advocate for pastoralist rights, argues that government officials:

fail to see a vibrant system of livelihood that supports an energetic and vibrant population of Tanzanians. A system that at minimal cost provides stable sources of animal protein to the majority of Tanzanians that ranching, with all its sophisticated paraphernalia, has failed to deliver (Tenga 2011, 19).

In recent decades, laying claim to "indigenous" status has offered marginalised communities, like African pastoralists and huntergatherers, routes to international alliances, collective strategies and financial support to combat their victimisation at home. Indigeneity - 
impossible to define and always contested - tends to be affiliated with the following characteristics:

The indicators, of which some but not necessarily all will be present at any time, are self-identification, historical continuity as a people, firstcomers, aboriginality, territorial connection with a region, distinct identity, marginalisation and discrimination, non-dominance, distinct culture and language, and being in a minority position. A few indicators could be seen as essential, such as self-identification, a wish to retain a specific identity, connection to a specific region, and a history of being dominated through eviction, assimilation, marginalisation, genocide or other forms of suppression or colonisation. Indigenousness seems further to be inevitably linked to the formation of modern states, which is part of the explanation why indigenousness acquired its global significance following the independence of former colonial territories in Asia and Africa and the collapse of the Soviet Union... (Dahl 2012, 190-91).

Parakuyo proudly self-identify as Parakuyo Maasai and as pastoralists, and they mark their distinctiveness through their dress and dialectic. But they do not tell histories of being first-comers. On the contrary, more often than not, they tell a highly formulaic narrative common to many if not all Maasai communities of being originally from the Levant, migrating over centuries to northern Africa, continuing in a southerly direction until reaching the area of what is now Nairobi, Kenya, where the sections (iloshon) parted ways to establish their respective territories. Parakuyo explain their lack of any identifiable territory through their near-genocide by the Kisongo, which caused them to be dispersed far and wide. The narratives they tell may be a contributing factor to their political persecution, for although archaeologists, linguists, and historians tell us that Bantu cultivators similarly traveled to East Africa from a point of origin in West Africa in the 'Bantu Expansion,' you will not often hear farming 
communities refer to themselves as being immigrants to the areas in which they now reside (Odgaard 2005; Maganga et al. 2007).

No more "indigenous" to central Tanzania than Maasai, Bantu cultivators nevertheless claim longstanding land rights as tillers of the soil, marking the earth with their crops, their graves and their permanent dwellings - all visible evidence of human occupation. Pastoralists, however, traverse the landscape leaving few traces of their engagement with the land. Until recently, they did not bury their dead. Until recently, they constructed temporary structures, easily dismantled or simply abandoned when the household would move in search of better pasture or water. Thus, the reiterated narrative one finds in Maasai communities of being originally from a vaguely but proudly identified elsewhere, while perhaps an attempt at reclaiming distinctiveness in the face of political marginalisation, inadvertently contributes to their marginalisation by offering neighboring farming communities fodder for denying the legitimacy of their claims to land and to equal representation in politics. Moreover, the connotation of foreignness that they encourage allows government officials to frequently evict them on grounds of being non-citizens, of being Maasai from Kenya who wandered over the border illegally, a claim difficult to refute since many Maasai lack official identification like passports or identity cards or birth certificates. ${ }^{76}$ One doesn't hear

\footnotetext{
${ }^{76}$ In response to a proposed government bill requiring livestock keepers to register and obtain ID tags for every animal they own, MP Benedict ole Nangoro argued that "the bills had not taken into consideration the fact that pastoralists were still using traditional methods to tend their animals... 'Pastoralists have no time to take their children to clinics or obtain birth certificates for them. How can they possibly take their cattle for registration?' he asked." (“Government withdraws livestock bills," The Citizen 04/15/2010.
} 
similar accusations lodged against the other ethnic groups (e.g., Luo, Kuria, Digo) similarly divided by the colonial borders and living in different nation states (see for example Coulson 1982).

Indigeneity is a frame of discourse that has recently come to be embraced by Maasai, as discussed at length by Hodgson $(2009,2011)$ and Dahl (2012). One need only consider the number of NGOs focused on pastoralist issues in Tanzania with the term embedded within, such as the Parakuiyo Pastoralists Indigenous Community Development Organization (PAICODEO) and the Pastoral Indigenous NGOs Forum (PINGOs). Unpopular with their government for claiming this status, which implies they precede other groups in the area, Maasai employ different self-labels as situations demand. For as Dahl argues, indigeneity proves to be less about prior settlement or authenticity than about vulnerability and rights denied.

'Indigenous peoples' is not an anthropological idea, nor is it only a modern term for earlier ideas of 'tribes', 'primitive people', or 'natives' as Beteille (1998) seems to indicate but a term used by an increasing number of peoples who themselves have been united by specific historical and global circumstances and conditions [that] precisely like all other social phenomena have trajectories in relationship with other peoples, movements or the creation of new political units such as the state (Dahl 2012, 190).

\section{Competing Discourses about Parakuyo Identity}

According to one common narrative, Parakuyo Maasai are more tradition-bound than the more dominant Kisongo Maasai due to their marginalisation within the greater Maasai complex and because so very few Parakuyo have attained any education beyond primary school. The dispersal of Parakuyo in minority enclaves across multiple regions of Tanzania has resulted in their being left out of many 
development initiatives. Pastoralist-oriented programs typically benefit Kisongo for ease of access. And given the correspondence between the Kisongo homeland and the most popular tourist destinations (e.g., Ngorongoo, Serengeti), the ensuing economic advantages have enabled considerable numbers of Kisongo to pursue advanced education. Thus it is not uncommon to find Kisongo professionals in the fields of law, politics, medicine, and education thanks to boarding schools in and around Arusha town for Maasai children, who are almost always Kisongo.

A second, competing narrative casts Parakuyo (along with Arusha Maasai) as being less-than-fully Maasai not on account of their military defeat but for being agro-pastoralists: communities that combine pastoralism with a heavy dose of agriculture. A Maasaicentric perspective would hold that only unsuccessful pastoralists would choose this option, but the realities of cattle disease, drought and decreasing access to grazing land made the choice one of economic necessity a long time ago, not only for Parakuyo and Arusha Maasai but also for Kisongo and other Maasai subsections. Archaeologists tell us pure pastoralism never existed, since the historical record is replete with evidence of trade between pastoralist communities and farmers. Yet, one consequence for many Parakuyo following the wars with the Kisongo was out-migration from the Maasai heartland to areas where they could find pastures for their livestock and to some extent land for cultivation. In 1962, Beidelman noted that "the Baraguyu are perhaps the most dispersed people in East Africa" and that they had been so for well over a hundred years (Beidelman, 1962, 8).

This second perspective thus holds that Parakuyo are innovators (as illustrated by the Lesoit example above), who are willing to experiment and not bound to an orthodox tradition. It thus reorders 
Kisongo-Parakuyo comparisons, with the Kisongo emerging (especially in tourist brochures and travel guide books) as the more traditional, more pure Maasai. Another strand of Parakuyo innovation concerns the theme introduced previously of sexual relationships. Odgaard has noted that Parakuyo men in Iringa and Mbeya regions often marry women from farming communities, for example from the Gogo, Bena and Sangu ethnic groups, who are more engaged in agricultural activities than the Parakuyo. ${ }^{77}$ While highly uncommon for a first (and thus most senior wife) to be anything but Parakuyo, a man's second or third wife might come from one of these communities, thus bringing agricultural knowledge and increased agricultural success into the family. One can see marriage and romance, then, as a strategy for diversifying household income that predates - by several generations - the recent migrations of Parakuyo warriors to Zanzibar and 'Mombasa Morans' in search of cash and the possibility of a European lover.

Whether Parakuyo or Kisongo can lay greater claim to 'Maasai-ness' or pastoralism as a way of life is a moot question. Both communities engage in a combination of pastoralism and agriculture, though interestingly both communities typically 'farm out' the labor of farming to those who do it best: farmers, either by marrying them or hiring them as day laborers. ${ }^{78}$ Both communities have retained a strong sense of being Maasai, and when faced with a common threat from invading farmers seeking to steal their land, they forge alliances and join forces against those whom they collectively refer to as olmeek, non-pastoralists (literally, "the uncircumcised ones"). And, both combine a passion for tradition with openness to innovation in equal

\footnotetext{
${ }^{77}$ A number of such examples were observed by Odgaard during fieldwork in Usangu Plains in 1985, 1990 and 1991.

${ }^{78}$ Yet, in the case of Lesoit, no one could identify a mixed Parakuyo-Bantu marriage.
} 
measure. What is of interest to us here, however, is how discursive assessments of traditionalism or innovation are used to further marginalise Parakuyo communities and further enhance the reputation of Kisongo. Whichever label gets applied to Parakuyo communities, it is applied in a negative fashion: they are either traditional to the point of being backward, or innovative to the point of no longer being true Maasai.

\section{Lesoit: A Minority Enclave}

During the 1970s, socialist-era efforts to both consolidate power and provide social services to the populace resulted in the moving of over 10 million people - some freely, most forcibly -into villages (vijiji) composed of at least 250 households. Operation Vijiji affected the vast majority of Tanzanians. Yet, there were communities that managed to duck its effects, namely those not dependent on a sedentary existence: hunter-gatherers and pastoralists. However, by the 1990s, the national government developed a sophisticated toolkit for dealing with these communities who, as noted above, were viewed with suspicion and derided publicly for not supporting the goals of modernisation. Hence, more and more hunter-gatherer and pastoralist communities have decided that adopting sedentarism, at least for official recordkeeping purposes, will tame some of the $21^{\text {st }}$ century lions that they now battle: low levels of education, inadequate access to healthcare, and continual, increasingly violent, strife with farming communities whose claims on land slowly but surely are cutting off the pastoral corridors they have been travelling seasonally for centuries.

Thus it was in 1992, two decades after most of Tanzania's 11,000 villages had been established, that 250 households of Parakuyo Maasai formally registered a new village with Kiteto District officials. One of only a handful of fully Parakuyo Maasai villages scattered across 
Tanzania, ${ }^{79}$ this community named their village 'Lesoit' for the natural granite reservoir in the village center. The 15,600 hectares that became Lesoit village was taken from the adjoining village of Lengatei, a village dominated by immigrant Nguu farmers who moved to the area in the 1970s answering the government's call to establish villages and attracted by the soil fertility of the Maasai Steppe. The steppe, by virtue of having been a "native reserve" set aside exclusively for Maasai pastoralists under British colonialism, had never been cultivated, and thus is today the site of much land grabbing and conflict.

So, to their south and to their east, Lesoit villagers are surrounded by farmers who view the land that to unknowing eyes looks unused with envy. Compared to the tidy rows of maize or beans that characterise the 8,700 hectares remaining in the densely populated Lengatei, the beautiful, large and untamed miombo woodlands of Lesoit - kept precisely that way for purposes of grazing cattle, goats and sheep looks, if not unused, then underused. Lesoit's elected and appointed leaders are frequent visitors to nearby courts, answering to or lodging lawsuits against invading Lengatei farmers. ${ }^{80}$

To the north and west lie the Kisongo Maasai villages of Loolera, Lembapuli, Olkitikiti and Engang'uengare, all of which engage in agricultural activities to the same extent or even more as the Parakuyo of Lesoit. Kisongo-Parakuyo cleavages remain most evident in

\footnotetext{
${ }^{79}$ According to interviews with Adam ole Mwarabu, coordinator of the Parakuiyo Indigenous Community Development Organization (PAICODEO), and Frank Kaipai, chairman of Lesoit village, there are only 22 majority Parakuyo villages in the country. Interview with authors, May 10 and May 23, 2012, respectively. ${ }^{80}$ We analyse two such cases in "Of Land and Legitimacy: A Tale of Two Lawsuits," forthcoming in Africa: Journal of the International African Institute, vol.. 28, no. 4, February 2013.
} 
marriage decisions, with few cross-subsection marriages occurring, and in their respective ritual schedules, with the initiation of new agegrade cohorts following different calendars. Nevertheless, they have come to each other's assistance in times of need, even waging together a violent if brief war against invading farmers from Nkama village in neighboring Kilindi District who sought to lay claim to an area of Lesoit with a natural water source shared by Lesoit and Loolera. That conflict, the Mtambalo conflict of 1998 (Mtambalo being one of the significant landmarks praised in the warrior's poem above), affirmed the worldview that these pastoralists share whatever their differences: their mutual commitment to living a life based largely, even if not exclusively, on pastoralism.

\section{Culture for Development and the Development of Culture}

One last example will serve to illustrate how Parakuyo of Lesoit are employing their cultural traditions to develop their community, in the process developing - or as described to us "improving and strengthening" - their cultural traditions. ${ }^{81}$ A problem that emerged recently in Lesoit (a problem that afflicts many communities in the country) is alcoholism. The community has a number of alcoholics who are slowly but surely selling off their cattle to support their drinking habits. Facing the prospect of having all the wives and children of these men reduced to relying on the village to support them, in 2002 the village leaders convened a meeting of their male elders and traditional experts. A long debate as to what to do and how to address the situation ensued, in which each member of the meeting spoke and offered an opinion. Although Parakuyo, like other Maasai communities, generally recognise male heads of households as owners

\footnotetext{
${ }^{81}$ The authors thank Jens Dahl for his contribution of the contrast between developing culture and culture for development.
} 
of the household cattle, the ultimate decision was to strip four men of their ownership rights to their cattle and instead recognise their wives as the legitimate owners of the household wealth.

This radical decision constituted a community-initiated (if maledominated) effort to prevent further erosion of the economic well being of these households and forestall their otherwise imminent impoverishment. Had they been reduced to destitution, these households would have likely been the beneficiaries of another Maasai tradition of holding a community cattle collection to help restore some wealth to these households. So, in this case, the alteration of cultural practice helped the community avoid collections for four families, which would have been highly unpopular and a heavy burden on the village. Taking the unusual step of recognising women as household heads - in these cases women who were not widowed, divorced or single - is a significant break from Maasai tradition. But, as all who spoke with us about it insisted, it was for the betterment of the community as well as these families.

Quite some time later, one of the authors happened to be telling the Kisongo manager of an NGO focusing on Maasai development about this breach of tradition. He was most impressed to hear about Lesoit's cultural intervention. He expressed surprise but then wished aloud that his Kisongo community would follow Parakuyo's lead and take similar steps in dealing with their problems with alcoholism.

\section{Conclusion}

The proudly Parakuyo Maasai of Lesoit face multiple threats from within and beyond their communities: predatory lions that stalk their cattle, cultivators that encroach on their land, government officials that undermine their rights to a pastoralist existence, inadequate 
access to education and healthcare, alcoholism, and gender discrimination. These are struggles common to Maasai and other pastoralist, as well as hunter-gatherer, communities throughout Tanzania and Kenya. They are also struggles common to indigenous communities throughout the world - struggles to avoid having their livelihoods fundamentally altered and their land forever alienated. The international indigenous rights movement has helped frame these demands for cultural self-determination within a rhetoric of human rights: that it is a basic human right to pursue a livelihood that has defined a community as a community for a long period of time. And, over the past two decades, Maasai have availed themselves of international fora, such as the United Nations, to lay claim to these rights while also continuing to agitate for equality at the national and local level.

Outside of such highly public venues, away from the attention of the media and state bureaucrats, Maasai are developing their own internal responses to the threats they face. The stories here from Lesoit show how a community under duress can draw strength from its traditions and simultaneously strengthen these same traditions to better serve collective needs. But here, as in most cultures, contradictions can be found. The pan-Maasai autohistorical narrative of foreign origins offers land-starved neighbors a weapon to use in challenging their rights of residence, even as their music and poetry shares intimate knowledge of the landscape, its features, and their placement within it. The warriors' pride in being Maasai and the guardians of a globally admired set of traditions masks the not atypical strategy of marrying or romancing women who happen to have desirable economic attributes, be it skill in agriculture or access to foreign exchange. And, at root lies the paradox that Maasai performative insistence on being members of an internationally recognised indigenous group through dress, language, and adherence to cultural practice contributes to their 
deepening marginalisation in a profoundly modernist and antipastoralist atmosphere.

The discrimination and violent advances that Maasai face from their governments and neighbors require them to be ever alert, ever vigilant, and to draw strength from their shared sense of self and communal reservoir of cultural practice. By performing that shared sense of self, making it manifest through celebrations after (or on rare occasion, before) killing a lion, through appearances in global venues defending the rights of indigenous peoples, or in local courts to thwart illegal incursions on their land, and through a military front when all other modes of negotiation fail, Parakuyo and Kisongo Maasai take indigeneity out of the realm of discourse and international politics and convert it into a tangible resource deployed in the battle for full legal and social recognition in Tanzania.

\section{References}

Beidelman, T. O.'A demographic map of the Baraguyu,' Tanganyika Notes and Records, 58 and 59 (1962): 8-10.

Beidelman, T. O. "The Baraguyu," Tanganyika Notes and Records, 55 (1960): 245-78.

Berntsen, J. L. 'The enemy is us: eponymy in the historiography of the Maasai.' History in Africa 7 (1979): 1-21.

Bruner, E. and B. Kirshenblatt-Gimblett. 'Maasai on the lawn: tourist realism in East Africa.' Cultural Anthropology 9, 4 (1994): $435-470$.

Coulson, A. Tanzania: A Political Economy. Oxford: Clarendon Press, 1982.

Dahl, J. The Indigenous Space and Marginalized Peoples in the United Nations. Basingstoke: Palgrave Macmillan, 2012. 
De Jode, H. and C. Hesse. Strengthening Voices: How Pastoralist Communities and Local Government Are Shaping Strategies for Adaptive Environmental Management and Poverty Reduction in Tanzania's Drylands. Tanzania: IIED, KDSC and TNRF, 2011.

Galaty, J. 'The eye that wants a person, where it can not see?' Inclusion, exclusion and boundary shifters in Maasai identity.' In Being Maasai: Ethnicity and Identity in East Africa, edited by T. Spear and R. Waller, 174-193, Oxford: James Currey, 1993.

Being Maasai, Becoming Indigenous: Postcolonial Politics in a Neoliberal World. Bloomington: Indiana University Press, 2011.

Hodgson, D. 'Becoming indigenous in Africa,' African Studies Review 52, 3 (2009): 1-32.

Jennings, C. C. 'Scatterlings of East Africa: revisions of Parakuyo identity and history, c.1830-1926.' Ph.D. thesis, University of Texas, Austin, 2005a.

Jennings, C. C. 'Beyond eponymy: the evidence for Loikop as an ethnonym in nineteenth-century East Africa.' African Studies Review 32 (2005b): 199-220.

Kipury, N. Oral Literature of the Maasai. Nairobi: Heinemann Educational Books, 1983.

Maganga, F. P., Odgaard, R. and E. Sjaastad. 2007. 'Contested identities and resource conflicts in Morogoro Region, Tanzania: who is indigenous?' In Conflicts over Land and Water in Africa, edited by B. Derman, R. Odgaard and E. Sjaastad, 202-214. Oxford: James Currey, 2007.

Meiu, G. P. 'Mombasa morans': embodiment, sexual morality, and Samburu men in Kenya,' Canadian Journal of African Studies/La Revue canadienne des etudes africaines 43, 1 (2009): 105-128. 
Ndagala, D. K.. 'The Ilparakuyo livestock keepers of Bagamoyo: persistent fighters but ultimate losers.' Working Papers in African Studies No. 32. University of Uppsala, 1986.

Odgaard, R. 'The struggle for land rights in the context of multiple normative orders in Tanzania.' In Competing Jurisdictions. Settling Land Claims in Africa, edited by S. Ewers, M. Spierenburg and H, 243-264. Leiden: Brill Publishers, 2005.

Ole Ndaskoi, N. Pastoralism on the Horns of a Dilemma: A Report of Consultancy Commissioned by PINGOs-Forum. Pastoralist Indigenous Non Governmental Forum, 2009.

Partridge, D. Hypersexuality and Headscarves: Race, Sex and Citizenship in the New Germany. Bloomington: Indiana University Press, 2012.

Spear, T. and R. Waller. Being Maasai: Ethnicity and Identity in East Africa. London: James Currey, 1992.

Tenga, R. 2011. 'Seeking redress from courts of law by pastoralists in Tanzania.' Paper presented to the conference on Half a Century Struggles by Pastoralists for Land Rights: Examining Achievements, Challenges and the Proposed New Constitution as a Window of Opportunity, organised by ALAPA \& PINGOs Forum, Arusha, 24-25 November 2011.

Waller, Richard. 1978. 'The lords of East Africa: the Maasai in the $19^{\text {th }}$ century (c.1840-c.1885).' Ph.D. dissertation, Cambridge University.

Weatherby, J. M. 1967. 'Nineteenth century wars in Western Kenya,' Azania 2 (1), pp.133-144. 


\section{EMERGING ETHNICITIES AND INSTRUMENTAL IDENTITIES}

IN AUSTRALIA AND BRAZIL

\section{Amanda Kearney}

Emerging ethnicities are about the personal and the political dimensions of people's lives. This is what makes them so rich for consideration in post-colonial and post-imperial spaces, where the conditions of their formation and maintenance have been profoundly affected by historical events. As identities have undergone episodes of shift and reformulation amidst changing social and political conditions, working with emerging ethnicities sets us on the path to better understanding the considerable variations that are found in individual life experiences within deeply political spaces. This chapter documents ethnicity as an emergent process in the contexts of Australia and Brazil, focusing on ethnic citizenries that are found at the heart of debates concerning equity and social justice. Focusing specifically on the discrete histories and experiences of ethnicity in these contexts, I begin the process of defining emerging ethnicities, seeking a more comprehensive methodology for working with ethnic citizenry in post-contact and often wounded spaces. ${ }^{82}$ In both cases what is examinable are the cross generational qualities of emerging ethnicity; namely the manner in which different generations come to embody and enact their ethnic citizenry. As a comparative study, I focus on three dimensions of ethnicity: the history and nature of ethnic citizenry, cross generational shifts in expressions of ethnic

\footnotetext{
${ }^{82}$ Wounded and interupted spaces represent instances where ethnic identity is a political project prefaced on collective and social memory that attests to difficult or traumatic histories and contemporary inequities. The inspiration for this terminology comes from Rose (2004).
} 
identity, and the strengths and vulnerabilities of those identities which are in a state of emergence. Through a focus on emergence, I challenge the myth of ethnic identity as singular, primordial, and immutable, and move towards a model of ethnicity as a making of identity, marked by qualities of fluidity and flexibility relative to contemporary socio-political situations and an aspirational future marked by the accordance of certain freedoms and rights.

Dominance of certain ethnic states and prevailing views on citizenry, enforced through nationalism and normalising judgements on what certain ethnic identities "look like," ${ }^{33}$ where they belong and how they might behave is at the core of what confronts emerging ethnicities. Emergence, with all of its associations with rising, genesis, newness, and manufacturing, is a powerful concept for engaging in the dialogic nature of ethnic citizenry. By harnessing the framework of emergence we find a space in which to recognise new expressions of old loyalties or new expressions of rethought, even new, loyalties. Emerging ethnicities are neither compromised, nor weak in their intrinsic value or for those who claim them. Their emergence is due to complex forces that have acted upon or been engaged by a cultural group, and strategic choices that are made in the reconfiguration of an ethnic identity around loyalties and ancestry. This could be a shift in the terms of membership, a move towards flexible notions of identifying, or a breakdown in earlier models of self-identification. Or, it could be a gradual dissolution in connections with ancestry and knowledge held to be distinct to a particular ethnic group. What causes these shifts to take place is multi-faceted. Reconfiguring ethnic identity and ethnic group boundaries goes beyond the legacy of cultural "assimilation" and cultural breakdown (Marks et al. 2007),

\footnotetext{
${ }^{83} \mathrm{~A}$ distinction which is made in terms of physical appearance, but also in terms of cultural expressions such as proficiency in a particular language, bodily aesthetics, politics, and beliefs.
} 
establishing the conditions to create something meaningful in the world right now.

The discipline of ethnic studies has generated several approaches to the study of ethnicity and therefore the unpacking of processes essential to identity politics. According to Levine, "the primordial approach situates ethnicity in the psyche, so deeply that society and culture are bent to its will. Ethnic identities and hatreds naturally draw people into persistent identities and antagonisms" (1999, 166). This approach has formulated an "understanding of ethnicity as rooted in deep-seated or 'primordial' attachments and sentiment" (Brubaker 2004, 49). Primordialism differs from instrumental adaptations to ethnic identity because it suggests an inability to shift according to circumstances. Whether manifest as deep-seated passions, or limited scope for a social existence beyond that which is circumscribed unto the individual and collective, memory and very particular styles of remembrance can work to create psychological essentialism around ethnic identity (Levine 1999, 166). Treating ethnic identity as primordial requires the particular relationship between the past and present to be enshrined in the sense of one's self as an individual and member of a collective. A primordialist approach to ethnicity allows us to consider how deeply held and subjective loyalties come to be mandated and often powerfully defended, frequently at the expense of new forms of ethnic expression or reformulations of loyalty and belonging. Whilst the ethnic arrival point may be claimed as primordial (in that it allegedly replicates what has always been), the journey taken to this destination is open to change as a result of historical particularities and contemporary conditions affecting the way things are remembered.

Today, the prevailingly view of ethnicity is that it is socially constructed (Yang 2000). In this vision of ethnicity, the process is 
linked to existing socio-political structures and human agency. Ethnic identity becomes the product of actions undertaken by groups as they shape and reshape their self-identification - actions often set against a background of external social, economic, and political processes (Nagel 1994). In sum, the process of ethnicity is highly relational and rarely fixed. Taken further however, viewing ethnicity as an instrument positions it in relation to choice, and consideration of the costs and benefits associated with ethnic group membership (Yang 2000). According to an instrumentalist position, when an ethnic choice becomes available, the costs and benefits of this identity play a pivotal role in determining the options. Alternative assertions of ethnic identity become possible only when an ethnic status quo is challenged and superseded. From this, something distinct is born: not altogether new, but distinct from an earlier form. Some people choose an ethnic affiliation not for material gains, rewards, or access to resources and services, but for emotional, intellectual, and political satisfaction, which includes states of wellbeing, self-fulfilment, social attachment or recreational pleasure (Yang 2000, 47). For human groups that occupy marginal spaces, and for those groups whose cultural specificity is born of a political project based upon wounding and reclamation, the capacity to create and emerge in ethnic form is an essential component of survival.

\section{Sociopolitical Contexts for Emerging Ethnicities and Instrumentalist Identities}

In Australia and Brazil, ethnic identities are realised or denied within frameworks of contested racial pluralism. In Australia, this escalated with the arrival of British colonisers, and a subsequent denial of citizenry and rights to indigenous people on the grounds of cultural difference and perceived racial inferiority. What followed were episodes of official and unofficial directives through policy and 
socialisation to establish differences, and create forms of sameness. Well documented directives which affected the realisation and denial of certain ethnic identities in Australia include the White Australia policy and waves of targeted migration, the forced removal of Aboriginal and Torres Strait Islander children from their families by government agencies and church missions, policies of assimilation, and the propagation of a national identity built on the politicisation of multiculturalism (Carey and McLisky 2009, Hage 2000, Short 2008) ${ }^{84}$.

In Australia today, Indigenous families and communities define their ethnic citizenries in a manner of ways along various lines of ancestry, language specificity, urban, remote and rural experiences, and political viewpoints - all with varying emphases on their Indigenous heritage. This is far from the early depictions of indigenous cultures as exotic and unchanging, and in other words, primordial and essentialist (Cowlishaw 1987, 225). Such imaginaries diminished "the active part Aborigines were taking in adjusting (or adapting) to the situation they found themselves in" (Cowlishaw 1987, 225). The perceived imminent loss of culture, upon which this view was predicated, fed primordial visions of Aboriginality as an ethnic identity. The impact of this cannot be underestimated. Primordialist notions have supported marginalisation, and the construction of an imagined 'authentic' indigeneity versus a diminished or non-traditional form of indigeneity

\footnotetext{
${ }^{84}$ The 'White Australia' policy describes Australia's approach to immigration from federation until the latter part of the 20th century, which favoured applicants from certain countries. The originas of the 'White Australia' policy can be traced to the 1850 's. In 1966 the Policy was abolished, and non-European migration began to cease.

Forced child removals occurred in Australia from approximately 1869 until 1969, although in some places children were still being taken in the 1970s. State and missionary justifications for this removal included alleged child protection, belief in a 'dying race' and fear of miscegenation (see Manne 2001).
} 
(see Cowlishaw 1987). Today, it is the Indigenous youth, those living in rural and urban centres, individuals and families of inter-ethnic descent, and those who differentially activate their indigeneity over their life course, that have become fringe dwellers in a climate of cultural tropes surrounding ethnic citizenry. Recent statements in the Australian media pertaining to indigeneity, such as "It's Hip to be Black" and "White is the New Black"(Bolt 2009) reveal a tension within public discourses of indigeneity, particularly within corners occupied by the White hegemonic ethnic norm, as to who is Indigenous, when is someone Indigenous enough, and what indigeneity mean in the context of contemporary Australia.

In Brazil, many similar social and structural conditions have functioned as catalysts for ethnic consciousness. Kinship, self-interest, and larger economic, political and social structures all underlie the social construction of Afro-descendant identity in northeastern Brazil. Discussions of ethnicity in these contexts are inflected by the historical particularity of a population with ancestral connections to a crossAtlantic slave trade that foreceably brought generations of people from Africa to Brazil. Today, many Brazilians identify as Afrodescendant, yet the manner in which they do so is highly dependent on a range of complex variables including individual choice (selfdeclaration), family history, socio-economic status, location of residence, and imposed categories used in demographic data collection by national bodies. African heritage is traced through a history of slavery in Brazil set to the rhythm of imperialism and nation building. Beginning in the mid 1500s, the Portuguese traded enslaved Africans - a practice which would continue until its official abolishment in 1888 with the passing of the Lei Áurea (Golden Law) and for some time after that through illegal channels of human enslavement (Klein and Luna 2009). The history of African slavery in Brazil sits prominently, if not uncomfortably, in contemporary 
narratives of nationhood. This is due, in part, to the nation's failure to reconcile its difficult and traumatic past, and the historical tendency for Brazilian nationalism to be prefaced on the notion of 'sameness' and the blurring of ethnic distinctions. The beating heart of Brazilian nationalism was based on the myth of social homogeneity (sameness despite difference) (Schwartzman 2007). What masks as harmonious ethnic encounters or 'social memory' of accommodation and assimilation in the annals of Imperial history is, for Ramos, best understood as a process of creating "a recipe for homogenous nationality... an amalgam of whitened races with a unique and uniform national flavour" (2001, 3). The singularity of Brazil has been a point of national reflection since the Declaration of Independence in 1822 and the founding of the Republic in 1889 (Lauerhass 2006, 1). These conditions have borne emerging ethnicities and have become spaces of power that challenge primordial notions of belonging.

Resistance to claims of homogeneity have manifest in powerful enactments of distinct ethnic identities. Afro-descent has emerged as a politicised identity that calls for the recognition of racial plurality: "difference amidst claims to sameness". The Brazilian Census of 2009 provided five options for self-declared 'race', along colour lines. These include, 'preto' (black), 'branco' (white), 'pardo' (brown), 'amarelo' (yellow) and 'indigena' (indigenous) (Instituto Brasileiro de Geografia e Estatística). Leaving aside the obvious deconstruction demanded of how colour relates to race and in turn to ethnicity, these colour declarations and that of 'indigena' can be seen to represent five more generalist ethnic identities. In 2009, 6.9 percent of the Brazilian population, self-identified as preto (black) (ibid.). For many who identify as such, life is framed by "deep disparities in income, education and employment between lighter and darker-skinned Brazilians", and these "have prompted civil rights movements advocating equal treatment" (Wideangle 2007). The declaration of 
one's self as 'black' sits in relation to declarations of ethnic identity such as Afro-descendant and Afro-Brazilian. This may or may not have reference to biological ancestry and involves varied associations with cultural ancestry. The emerging state of being, along lines of cultural specificity, and denial of ethnic homogeneity, is a condition of cultural strength rather than weakness. Wolf $(1982,387$, in Cowlishaw 1987, 227) paints a picture of emergence as instrumentalist, in the following terms:

In the rough and tumble of social interaction, groups are known to exploit the ambiguities of inherited forms, to impart new evaluations or valences to them, to borrow forms more expressive of their interests, or to create wholly new forms to answer to changed circumstances...'A culture' is thus better seen as a series of processes that construct, reconstruct, and dismantle cultural materials, in response to identifiable determinants.

\section{Moments of Emergence: Examples from Australia and Brazil}

Throughout the course of ethnographic fieldwork in Borroloola, northern Australia, and northeastern Brazil, I have come to witness distinctions across generations and within self-declared collectives, according to ethnicity. In the first instance, I have observed the ways in which younger generation Indigenous people, as members of Yanyuwa families, shape their way of being Yanyuwa on new and creative terms. Secondly, in working with Brazilian educational bodies and affirmative action groups built up around an Afro-descendant ethnic identity, I have come to witness some of the ways in which younger people shape their Africanness into a political and social project of belonging.

The dynamic quality of Yanyuwa culture is embodied by crossgenerational distinctions in what people choose to remember and forget, and what triggers exist in daily life to affect these moments of 
consciousness around a particular ethnic identity. Yamanouchi (2010) has recently explored Indigenous identity politics in contemporary urban contexts of Australia. Her work, sophisticated in its articulation of flexible notions of identification, moves beyond essentialist and fixed notions of identity. Yamanouchi (2010) highlights the internal and external politics of urban indigenity and the terms of identification and affiliative kinship. In Australia, narratives of young Indigenous people's lives are most often contained in the literature of social inquiry under the categories of education reform, mental and physical health, and inter-generational relations. There remains a tone of imminent loss in the representations of their lives, due in part, I argue, to the perceived "lack" of "primoridalist" indicators detectable in their expression of an ethnic identity; namely the capacity to enact "traditional" cultural expressions, mastery of Indigenous language, unbroken attachments to the places of their ancestors, and apprehension of distinct bodies of knowledge. The ethnography of childhood deeply ruptures many of these assumptions, revealing that the nature of childhood is sensitive to "population-specific contexts," and understanding the terms of childhood can only be achieved with "detailed knowledge of the socially and culturally organized contexts which give them meaning" (LeVine 2007, 247).

Working with Yanyuwa families on a series of cultural maintenance projects over the years has afforded me the opportunity to work across age groups. Faced with degrees of social and cultural change, families have responded to their experiences of a long-running colonial frontier, on self-determined terms, modifying their lives in a mode of cultural survival and dynamism. To date, a range of memory projects in formats including text, film, imagery and sound projects have been undertaken. One particular project that has directly involved the interests and feedback of young people has been the Yanyuwa Animation Project. Production commenced in 2007 as a result of a 
community-based discussion around a crisis in cross-generational knowledge exchange. To date, it has seen the production of a 20minute bilingual DVD of ancestral narratives, and two additional DVD productions of kujika (songlines) (Yanyuwa Families 2009, 2010a, 2010b). A third and fourth production are currently underway. Confronted with a difficulty in offsetting the dominance of nonindigenous education programs within the community, and the passing away of elders armed with ancestral knowledge to share with younger generations, members of the community sought the means to produce representations of law and culture in formats appealing to young people.

Identifying the world in which young people occupy their imaginations was pivotal in the early phases of the project. In discussion with Yanyuwa elders, and from mid-generation to young people, we were able to ascertain the formats most appealing to young people in the re-presentation of their ancestral knowledge. A resounding theme in these discussions was the appeal of television, cartoons, and animation for young people, as these forms of media capture the imaginations of younger generations who are highly visually literate. What is clear in the midst of Yanyuwa youth identity politics and cultural maintenance projects is that a process is underway, in which ancestral identities re-emerge or re-present themselves through contemporary events and expressions (Le, 2009) and from this comes a range of new understandings and enactments of ethnicity. This process takes on speed in contexts of cultural affirmation and is internalised by young people in ways that makes sense to their world today. An emerging Yanyuwa ethnicity is about reconfigured identity politics that reflect human agency and the choices that are activated in the construction of ethnic states. Da Costa (2010) documents similar processes amongst Afro-descendant groups in northern Brazil. He articulates the process of emerging ethnicity as 
one that draws upon ancestralidade (ancestry) in a particular manner in crafting and shaping a present sense of ethnic self and ethnic membership (2010, 665). This is about creativity, agency and choice, not disconnection and loss.

Ethnographic fieldwork in Brazil has placed me in contexts of working with individuals (both friends and associates through the research) who identify as Afro-descendant and collectives articulated around an Afro-Brazilian identity and activism kinship through the black rights movements. My ethnography involved working in friendship, activist, and academic contexts with the Instituto Cultural Steve Biko, Centro de Estudos Afro-Orientais (Federal University of Bahia), and Ilê Aiy $\hat{e}^{85}$. Working with Afro-descendant collectives I have observed the emergence of ethnic states that involve processes of remembering, and commemoration of a loyalty built around what is remembered and channelled into a politico-creative project.

In 2010, the Statute of Racial Equality was ratified by the Brazilian government. Received by some as a historical achievement, for others it failed to redress the long history of inequity experienced by Afrodescendants within Brazil. The document simultaneously reaffirms the black population's right to health, housing, and cultural expression, as guaranteed by federal and municipal authorities by

85 The Instituto Cultural Steve Biko is an organisation working to assist Afrodescendant students transition through educational phases into university. The Institute's objective is to "arm and equip students to use education as a weapon against oppression" (Instituto Cultural Steve Biko).

Ilê Aiyê was founded in 1974, as a Carnaval group in the neighbourhood of Liberdade in Salvador, Bahia. Members work to raise consciousness around the Bahian black community and strives to reinvent "the meanings of Africa and Africanness as a basis for constructing new cultural and aesthetic symbols" (Pinho 2010, 2). 
means of social and economic policies, and highlights the affirmation of compulsory teaching of African history (Federal Law 10.639). Yet, it references no need to make reparations for slavery and for the description of the slave trade as a crime against humanity, with no period of limitation (Frayssinet 2010). Black Rights collectives committed to programs of tackling residual inequity and racist public policy find cold comfort in the fact that the Statute fails to endorse affirmative action through policy initiatives. Reference to racial quotas as a mode of redress of inequitable access to education and employment for Afro-descendants was eliminated from the Statute (Frayssinet 2010). Today, Brazil has 98 public universities and many of them use racial quotas in some manner, with variations found in the percentage of required positions made available to both Afrodescendant and indigenous students. In recent years there have been questions as to the constitutionality of racial quotas, and pressure to have them ruled unconstitutional under current Federal law. In April 2012, the Brazilian Supreme Court, however, moved to approve racial quotas in universities (Hayman 2012).

The issue of affirmative action through racial quotas is a deeply controversial one, which cuts to the core of the myth of racial democracy in Brazil and lifts the veil on perceived and real difference, and equality and social justice concerning an equal share in the benefits of a good life for all Brazilians (dos Santos 2006; Ekey 2010). It also generates an interesting context to observe the emerging state of an ethnic identity articulated around blackness and African descent. According to Bailey and Peria (2010), the quota system aims to increase representation of the formally excluded population, and achieves this by reserving a share of available positions for members of the targeted group. I ask then, how racial quotas in universities throughout Brazil may work to reveal the emergent nature of ethnicity, and how, through emergence, collectives can mobilise 
ethnicity as an instrument. How might these efforts at redressing inequity along ethnic lines support an emerging ethnicity in its rising up with vigour and strength along lines that are not merely about physiology, but also about new cultural expression and reclamation of a social and political ancestry? "[T]hese developments reveal a context where black movements find themselves" moving within the realities that "emerge from the relational and diasporic history of slavery and capitalism" (Da Costa 2010, 660). It is such that claiming the space to be Afro-descendent is articulating the process of ethnicity as an alternative to social class, as a subjective loyalty of another kind, and as a way of mobilising a communal affiliation in the face of marginalisation. However, for those who make that claim, there are challenges to the legitimacy of this position. Contentious public debate around racial quotas has drummed up individual and group negotiations as to who "rightfully" qualifies as Afro-descendant and who does not. Similarly, the questions are asked: who is black, when are you black enough, how is blackness defined, and what constitutes black culture? (see Zabaki and Camargo 2007). It is within the framework of a deeply political and creative project that the terms of an Afro-descendant ethnicity are born. It is a creative negotiation of the present reality lived by many Brazilians who identify as "black" or "brown" that leads to the shaping of this emerging identity. It is this that informs an individual's choice to declare their ethnic status (in applying through racial quota programs), and it is also this that is scrutinised and judged by hegemonic ethnic norms. Prandi explains the emergence in the following terms:

Retrieving the ancestral past, which no longer has much meaning today, makes us elaborate a memory patched together with the mythical signs that emerge into the present. From today's Brazil we remake the Africa of the past. A symbolic Africa, the possible memory and identity of the Afro-Brazilian people. (2004, 42-43). 
I argue that states of emergence in identity politics do not diminish the value and importance of certain ethnic identities however much they might challenge the status quo, appear to be "born over-night," or opportunistically engaged. Critiques of affirmative action and identity politics around new forms of expressing an indigenous identity or one's Afro-descent often cites its emergent quality as argument against the rise and vigour of an emerging ethnicity. Viewing political or social action around ethnic identity as illegitimate, "trouble making" (as often witnessed in the media and political debate around certain ethnic identities and their "privileges"), or as threatening the stability of national identity, is flawed, not only because it is racist, but simply because it disregards the current state of play in any given country or region. The state of play is what is "present" and this is what remains after certain political histories; people negotiate these realities in their daily lives.

\section{Overview: Strengths and Vulnerabilities in States of Emergence}

For emerging ethnicities, strengths and vulnerabilities are both identifiable. The vulnerabilities faced by young people concern wider acceptance of their emerging ethnicity as valid and legitimate. The ongoing reality of state intervention into the lives of the Indigenous in Australia, and Afro-descendants in Brazil is such that notions of ethnicity are not entirely self-defined. The marginalised - irrespective of population size - can remain marginal through institutionalised racism and hegemonic ethnic norms, as well as embedded ideologies passed down through certain logics that pervade governments. Both in Australia and Brazil, the experiences of those who claim emerging ethnicities are not isolated. In fact, the processes they undergo are common to all wounded and interrupted spaces. It is such that for many populations, their emergence along ethnic lines is not simply about recovering or mimicking a tradition or static memory of the 
past. Instead, whilst the past is valuable, it is just one part of how individuals might see themselves and their community in the present and how they envision possibilities for the future. With the support of kin (biological or affiliative), young people in northeastern Brazil and Indigenous Australia can increasingly find spaces for affirmation of their identity and for the performance of an emerging ethnicity that is a definitive site of power and strength for themselves, and also for their wider communities. At the same time,, they have distance and closeness to the colonial and imperial frontiers that interrupted the lives of their ancestors, and this comes to inform their identity politics in creative and often deeply political ways. Their emerging ethnicities are often about the pursuit of an identity in order to move forward. Hence, they are much more about vigour, genesis, and flourishing than they are about loss, assimilation, or rupture.

\section{References}

Bailey, S. and M. Peria. 2010. 'Racial quotas and the culture war in Brazilian academia.' Sociology Compass 4, B (2010): 592-604.

Bolt, A. 'White is the New Black.' Herald Sun, April 15, 2009, Accessed September 13 2012, http://blogs.news.com.au/heraldsun/andrewbolt/index.php/h eraldsun/comments/column_white_is_the_new_black

Brubaker, R., Loveman, M., and P. Stamatov. 'Ethnicity as Cognition.' Theory and Society 33, 1 (2004): 31-64.

Carey, J. and C. McLisky. Creating White Australia. Sydney: Sydney University Press, 2009.

Cowlishaw, G. 'Colour, culture and the Aboriginalists.' Man 22, 2 (1987): 221-237. 
Da Costa, A. 'Afro-Brazilian Ancestralidade.' Third World Quarterly 31, 4 (2010): 755-674.

dos Santos, S. 'Who is Black in Brazil?' Latin American Perspectives 33, 4 (2006): 30-48.

Ekey, V. 'The Afro-Brazilian University Experience.' ISP Collection. Paper 946. 2010. Accessed May 8, 2012. http://digitalcollections.sit.edu/isp_collection/946.

Frayssinet, F. Controversy Dogs Brazil's Racial Equality Law. IPS, July 9, 2010. Accessed May 8, 2012.

http://ipsnews.net/news.asp?idnews=52107.

Hage, G. White Nation: Fantasies of white supremacy in a multicultural society. London: Routledge, 2000.

Hall, G. Slavery and African Ethnicities in the Americas. Chapel Hill: University of North Carolina Press, 2005.

Hayman, M. 2012. 'Brazilian Supreme Court Approves Racial Quotas in University.' Latin American News Dispatch, April, 29 2012. Accessed May, 8012. http://latindispatch.com/2012/04/29/brazilian-supremecourt-approves-racial-quotas-in-university/.

Instituto Brasileiro de Geografia e Estatística (IBGE) Table 1.3.1, "População residente, por cor ou raça, segundo o sexo e os grupos de idade." Accessed February, 152012. www.ibge.gov.br/home/estatistica/populacao/censo2010/cara cteristicas_da_populacao/caracteristicas_da_populacao_tab_ brasil_zip.shtm).

Instituto Cultural Steve Biko. Accessed April 24, 2012. www.wix.com/cabralbete2/biko\#!quem-somos.

Karasch, M. 1987. Slave Life in Rio de Janeiro Princeton: Princeton University Press, 1987.

Klein, H. and F. Luna. Slavery in Brazil. Cambridge: Cambridge University Press, 2009.

Lauerhass, L. 'Introduction.' In Brazil in the Making, edited by C. 
Nava and L. Lauerhauss, 3-15 Oxford: Rowman and Littlefield, 2006.

Levine, H. 'Reconstructing Ethnicity.' The Journal of the Royal Anthropological Institute 5, 2 (1999): 165-180.

LeVine, Rt. 'Ethnographic Studies of Childhood.' American Anthropologist Vol.109, 2 (2007):247-260.

Manne, R. 'In Denial: The Stolen Generations and the Right.' The Quarterly Essay 1(2001): 1-113.

Marks, A. K., Szalacha, L. S., Lamarre, M. Boyd, M., and C. García Coll. 'Emerging Ethnic Identity and Interethnic Group Social Preferences in Middle Childhood.' International Journal of Behavioral Development 31, 5 (2007): 501-513.

Nagel, J. 'Constructing Ethnicity.' Social Problems 41, 1 (1994): 152176.

Narnu-Yuwa ki-Anthaa: The Dreamings from the Saltwater Country. Dir. Yanyuwa families, John Bradley and Brent McKee. 2010. Film.

Pinho, P. Mama Africa: Reinventing blackness in Bahia. Durham: Duke University, 2010.

Prandi, R. 'Afro-Brazilian Identity and Memory.' Diogenes 51 (2004): 35-43.

Ramos, A. 2001. 'The Predicament of Brazil's Pluralism.' Paper presented at Beyond the Boundaries of the Old Geographies Conference, Accessed August 22 2012, http://vsites.unb.br/ics/dan/Serie303empdf.pdf.

Rose, D. B. Reports from a Wild Country: The ethics of decolonisation. Sydney: University of New South Wales Press, 2004. Schwartzman, L.

'Does Money Whiten? Intergenerational Changes in Racial Classification in Brazil.' American Sociologist 72 (2007): 940-963.

Short, D. Reconciliation and Colonial Power: Indigenous Rights in Australia, Aldershot: Ashgate Publishing, 2008. 
Wideangle, 'Black and White Brazil', 2007. Accessed December 5, 2011. www.pbs.org/wnet/wideangle/episodes/brazil-in-blackand-white/introduction/965/.

Yamanouchi, Y. 'Kinship, Organisations and 'wannabes': Aboriginal Identity Negotiation in South Western Sydney'. Oceania 80 (2010): 216-228.

Yang, P. 2000. Ethnic Studies. New York: State University of New York.

Wirdiwalangu Mayangku kulu Anthawirriyarrau - The Law that comes from the Land, the Islands and the Sea. Dir. John Bradley, Brent McKee and Yanyuwa families. 2009. Film.

Wundanyuka kulu Jujuju - The Sea Turtle and the Osprey. Dir. Yanyuwa families, John Bradley and Brent McKee. 2010. Film.

Zabaki, R. and L. 'Camargo. Raças não existe'. Veja, June 6, 2007. Accessed December 5, 2011. http://veja.abril.com.br/060607/p_082.shtml 


\section{RESISTANCE AND EXISTENCE: NORTH AMERICAN}

\section{INDIGENOUS HUMOUR OF THE $21^{\mathrm{ST}}$ CENTURY}

\section{Daisy Purdy}

Historically dated and stereotypical images of Native Americans stand in stark opposition to the notion of contemporary emergent indigenous identities. By contrast, Native North Americans are asserting their existence in modern day America in myriad ways such as through humorous images, literary descriptors, ceremony, and music that assert not only their presence but the complexity of who they are. To see examples of dominant - albeit problematic - images of indigenous Americans, one needs to go no further than typing "Native American" into an Internet search engine and comparing those results to a search for "White American." While Native identity is represented by centuries-old images, White identity is marked by modern identifiers of American-ness such as jeans and t-shirts.

My interest in researching Native humour stems from frustration with iconic images of stoic Natives juxtaposed with the reality of urban Indian identity, and my professional experience working with Native American Student Services (NASS) at a state university. NASS employees are continually confronted with staggering numbers of Native student dropouts, partly due to the seemingly insurmountable personal barriers our students face. In response, our staff adopted a comedic approach to combating the stress associated with this daily reality. We joked about getting capes and masks, and demanding funding from the office of the president to support our program because we are "Super Injuns" complete with our trusty donkey mascot: the NASS ass. We laughed about generating revenue through the sale of a geriatric professor "nudey" calendar. When $3 / 4$ of us 
learned of the most recent Native student suicide on campus and another staff member walked in late and asked "why so down?", we all responded with a different reason, each equally absurd and culturally comedic:

- "We just got news that the buffalo are back and we don't get cell reception on the plains."

- "We drew straws to determine who gets laid off and all of us got the short straw."

- "Josh's girlfriend lied about her clan, so she's his girlfriend and his grandmother."

We recognised that our students, regardless of their level of traditionalism, were trying to navigate two worlds, where the dominant world doesn't understand why a death in the residence hall is so personally devastating if the victim isn't your best friend or roommate. Professors would expect our students to perform "normally" in class since the deceased student was not a member of their nuclear family, with the larger spiritual implications often dismissed as superstition. We understood the wake that would follow and the need for us to pick up the pieces with limited resources, but rather than externalising it for what it was, we swallowed hard and replaced the stagnant air with laughter -survival humour.

House fires, suicides, death, disease, genocide, poverty, and hunger are not funny. Natives struggling to maintain their dignity and their identity in a dominant culture that is intent on the acquisition of ancestral lands and natural resources is also no laughing matter. Loss and pain, dependence and helplessness, sovereignty and paternalism do not offer much in the way of comic relief. So, why are these areas targeted in Native humour and contemporary conversation? I would respond by saying that humour is part of our identity. And while not 
all Native humour finds its birth in the response to suffering, some of it does.

As is evident in our NASS staff meetings, the ability to laugh at yourself enables you to avoid continued victimisation and to sustain yourself through survival humour. Laughing becomes a way of coping with pain - it is created from the ashes of defeat (Chavkin 1999, 168).

After five hundred years of dispossession - germ and conventional warfare, bounty hunting, guns, ploughs, telegraph poles, trains, barbed wire enclosures, land swindles, and outright stealing - Native people still persist on some 53 million acres of reservation land left over from the great dirt grab... Clearly humor both targets and takes some fatal sting out of history" $(1999,345)$.

Contemporary Native artists, writers, and musicians use humour to forge new versions of Native identity that resist stereotypes, and offer a means of expressing solidarity in the face of contemporary legacies of colonialism. Fossilised images that became synonymous with dominant ideologies of "Nativeness" are being reclaimed by Native North Americans and infused with ironical humour through various mediums such as literary arts, performing arts, and studio arts. Vine Deloria and Gerald Vizenor approach the comical emergent identity of contemporary Native North Americans as a traditional legacy internalised and reshaped with new meaning - deconstructing stoicism and imagined stagnation.

Without the emergence of published contemporary indigenous humour, Native Americans who don't fit the stereotype would become disposable: omitted from a modern existence. Indigenous humour focused on the ridiculousness of dominant generalisations of Native identity facilitates the public emergence of contemporary indigenous identity. Dozens of contemporary Native artists utilise humour to 
deconstruct these stereotypes by reversing the lens and poking fun at those who believe them rather than mocking the populations that the stereotypes are intended to represent. In this regard, humour becomes a weapon to strategically challenge the old notions of Natives by making it absurd and ironic.

Humour is a significant facet of tradition and a survival strategy of Native Americans that challenges the dominant construction of Native stoicism. This chapter explores the use of ironic humour as a coping mechanism enabling continued existence while navigating outside of the culture of power. Its intent is to promote the decolonisation of Native identity by deconstructing controlling archaic images, and to provide a glimpse into the complexity of contemporary Native North America through indigenous humour in literature, performance, and studio arts.

\section{Literary Arts}

Alexander Posey is known as one of the foremost authors of Indian humour. He wrote letters to an "insider" Creek audience, avoiding mainstream exposure (1993). The messages were largely political in nature, addressing issues of federal and tribal policy, sovereignty, citizenship, and voice. Craig Womack describes his approach as "the next link in developing a new brand of Indian humor" $(1999,172)$. Posey purchased the Indian Journal in 1902 and developed a reputation as a political satirist. His satirical utilisation of dialectic humour provides an authentic voice to characters that are relatable to the Native audience, and that encourages them to reverse the lens and apply the lazy, useless stereotype to white counterparts, all while not veering from historical accuracy.

Sherman Alexie, like Posey, relies on broad stereotypes of Native Americans as the focus of his satire. The dated, but commonly used 
stereotype of the buffalo-hunting, horseback riding, breech-clothwearing, feather-headdress and war paint adorned, teepee-dwelling noble savage is constructed largely as a result of inaccurate popular history, and exemplified in Alexie's Great American Indian Novel. When teaching about American history, elementary schools often incorporate the themes and images associated with plains Indians, suggesting that all Native American cultures (of which there are over 500) parallel this romanticised notion of America's indigenous peoples (Fleming 2007, 53). The cycle continues through pervasive and stereotypical images in the media and character roles, which create a vast gap in real versus imagined Native America - one of many examples of how "...they [desire] Indianness, not Indians" (Deloria 1969, 90). In this regard, Indian people are irrelevant to "Indianness" in White middle-class America. Alexie deals with such complex and depressive notions with an edge of humour.

Sherman Alexie's humour, made caustic by social consciousness, transcends racial and tribal boundaries in The Toughest Indian in the World (2000). Alexie allows the non-Native reader to be drawn into reservation reality forcing them to replace the media perpetuated John Wayne Indians of yesteryear with contemporary salmon-fishing warriors. His audience is able to laugh at the characters' experiences as they strive to survive, yet Alexie achieves this without denying or downplaying the deprivation and injustice in Indian country. This author cleverly utilises Native/non-Native relationships with shifting degrees of power and no clear resolution, thus enabling access to a diverse audience while addressing the complexity of race relations without alienation - through humour.

This bipolar approach to pain and perseverance is evident throughout the collective narratives of characters in Alexie's storytelling. The juxtaposition of humour and hurt in his characters' trials and 
tribulations challenges the non-Native audience to consider Natives as complete persons, rather than the iconic noble savage commodified and indoctrinated into mainstream society. Navajo (Dine') comedians James and Ernie have taken "Alexieesque" survival humour on stage with increasing popularity among Natives and mainstream fans.

Vine Deloria Jr emphasizes the significance of humour cross culturally. He is most commonly cited for stating that to know a culture is to understand its humour. Deloria explicates the prevalence of thematic contemporary humour as a reaction to the continuation of cultural genocide. The title of his progressive text, Custer Died for your Sins (1969), introduces the complexities of historical legacy on contemporary identity. The reader is begged to judge the book by its cover, or, more accurately, its title, and question the legitimacy of our national heroes, Custer and Columbus, to question our institutions and policies, the Bureau of Indian Affairs, Indian Health Services, and Federal Indian Policy, as well as to question our acceptance thereof.

Deloria (1969) discusses humour as an indigenous tradition where one can acknowledge the shortcomings of another through teasing, or where one can acknowledge their own mistakes through humorous self-deprecation. Such strategies are not socially punitive or belittling; they empower the individual/society to address the need for change and encourage them to revisit the issue armed with humour. The significance of humour as a tradition is evident in the commonplace existence of a tribal "trickster" figure among many Native North American nations. The trickster makes mistakes that are lamentable but laughable, teaching us important morals and lessons that are accessible to in-group audiences across generations. The "trickster" has transcended centuries and emerged from utilitarian tales of preColumbian Americas to twenty first century quandaries, while maintaining relevance through the ages. 


\section{Studio Arts}

Much like Deloria's utilisation of traditional trickster humour in contemporary America, author Allan J. Ryan (1999) explains that "several artists were beginning to playfully exploit the perception of Native peoples as living museum pieces" (Ryan 1999, 14) through the use of studio arts. The irony of the emergent humour is intended to deconstruct romantic idealisations that deny $21^{\text {st }}$ century existence and exclude Native North Americans from "normalcy," "representing cultural stereotypes in humorous and ironic fashion to renew not only their ideological underpinnings, but also the way in which historical misconceptions have hindered cross-cultural understanding and interactions." (Ryan 1999, 104).

Ryan (1999, 14) describes Bill Powless' Beach Blanket Brave (1984, acrylic on canvas board, $51 \times 41 \mathrm{~cm}$ ) painting as "pure play and ironic juxtaposition." Powless challenges antiquated historic stereotypes by playing with modern consumerism; one has to look twice to verify that the brave is branded by Speedo, brandishing a newspaper and an inner tube in lieu of a shield and weapon, and clad in a cotton towel replacing more common romanticised images of buckskin and loin cloths. Powless increases indigenous identifiers paradoxically with braids and feathers, but requires the viewer to challenge Native stereotypes both geographically; an ocean-side plains style hair dress and chronologically, since Speedo made its debut post-buffalo-hunt. In a self-portrait, Powless defies stoic imagery with a playful grin, jester's hat, and a fake flamingo titled "Self-Portrait as April Fool" (1995, graphite on paper, $29 \times 22 \mathrm{~cm}$ ).

In Powless' "Home of the Brave" (1986, acrylic on masonite, $61 \times 76$ $\mathrm{cm}$ ), feathers and beads are similarly used as identifying markers, though not reflective of the artist's tribal affiliation. The visible irony of garb may be lost on an out-group audience, but the title of the 
piece, the flamingo, and the Pepsi can, are iconically unavoidable. They mark the existence of contemporary indigenous identity, while questioning an emergent biculturalism - therefore juxtaposing the existence of a modern self with a marketable romanticised self. Powless addresses this binary with self-deprecating humour. First Nations artist Carl Beam reinforces the idea of indigenous existence in a modern world in his version of a "beach blanket brave", Self-Portrait in My Christian Dior Bathing-Suit (1980, watercolor on paper, $106 \mathrm{x}$ $69 \mathrm{~cm}$ ). Continuing with the theme of stereotype deconstruction and twenty first century existence, artist Ron Noganosh used oil, cardboard, and Plexiglas to create a nude self-portrait comically titled I Couldn't Afford a Christian Dior Bathing-Suit (1990, oil, cardboard, Plexiglas, $142 \times 86 \mathrm{~cm}$ ). The irony and banter of these images make a powerful statement about the absurdity of archaic identity and presumed stoicism addressed in Ryan's The Trickster Shift (1999).

Native North Americans such as Shelley Niro and Noganosh, depict indigenous Americans in Euro-American codification through mixedmedium art. Obvious titles of inclusive Americanism accompany these art works. Niro's 500 Year Itch (1992, hand-colored gelatin silver print, $36 \times 28 \mathrm{~cm}$ ) is an ironic self-portrait with the artist depicted in the famous white dress of American Actress Marilyn Monroe, while Love me Tender (1992, hand-colored gelatin silver print, $36 \times 28 \mathrm{~cm}$ ) captures Niro emulating iconic American singer Elvis Presley's attire, complete with guitar. Niro has a series of pictures featuring her mother draped over jalopies, encouraging laughter from the obvious juxtaposition of poverty and opulence (1992).

The Senecas Have Landed (polymer acrylic on canvas) by Carson Waterman, 1982, requests that man take one small step by including indigenous populations in our collective global psyche through the humorous painted imagery of a Native Neil Armstrong. Perhaps the 
artist also intended to question the nature of the current "alien" status as John Kahionhes Fadden did in Wouldn't it Be Funny? (1983, acrylic on canvas, $64 \times 53 \mathrm{~cm}$ ). These contemporary Native artists feature indigenous subjects clad in Pierre Cardin, nude, abstract, modeling atop cars, all with similar themes of existence in modern North America, and coping through survival humour. While EuroAmericans perpetuate stereotypic nostalgia, contemporary Native artists recreate themselves through humour because the Native-ness that is imagined in dominant society reflects the "vanishing Indian" myth.

Each of the previously discussed art pieces seem to challenge nonIndian audiences to eschew dominant stereotypical views of the Native and to embrace more complex understandings of their modern existence. Perhaps they also allow Native audiences, through use of satire, irony, and humour, a space to laugh and ultimately cope with life in modern America.

\section{Performing Arts}

Gerald Vizenor traded his metaphoric bow and arrows for ink and paper, making literary contributions that address the complexities of emergent indigenous identities by utilising a comedic approach he describes as "mythic verism"; verism is a belief that literary art is a reflection of truth and therefore cannot exclude the crude and unsightly components of society. "Mythic verism" acknowledges that "the truth is in the telling" (Harold of Orange, 1984), thus the trickster is an active player in recreating reality. Vizenor satirises mainstream society by focusing on a modern-day trickster that is traditional in form but exists beyond the romanticised snapshot of historically fixed "authentic" Indians. In the film Harold of Orange, Vizenor's screenplay unfolds the power dynamic of indigenous sovereignty, 
federal paternalism, and liberal romanticisation through social underdog humour.

Vizenor contests oppressive hegemonic ideologies and repressive apparatuses by satirising mainstream society. His cast, ironically referred to as the "Warriors of Orange", is empowered by reclaiming the stereotype that has denied their existence in a modern world. They embody a humorous emergent Indian identity by using a warped time paradox. Much like Powless' Beach Blanket Brave (1984), the 'warriors' of the orange grove savagely fight off figurative parasitic insects while maintaining a noble awareness of organic agriculture. Both Vizenor and Powless demystify Native America through the inclusion of Indians indulging in leisure, and "normal" twenty first century pastimes.

Neckties are strategically worn by the "Warriors" to reinforce their belonging in a modern corporate world, accompanied by verbal banter that addresses the ridiculousness of selling ones indigenous identity to a mainstream audience - "the white man turned white by wearing neck ties. It cut off all of the oxygen to his brain" (Harold of Orange, 1984). Not only does Vizenor address hierarchical racial stratification evident in racial/ethnic relationships in the United States, he forces the audience to question the contemporary "professional" attire of mainstream society, thus challenging the lens through which dominant society views 'acceptable' behavior. Vizenor's "Warriors" are battling against mainstream society for existence in contemporary capitalist America, armed only with their opponent's underestimations: the pervasive belief that Native Americans are a primitive, non-diverse, stoic people.

The 'Warriors' in Harold of Orange must appeal to a majority group of economically privileged potential donors so they meet them on their corporate battlegrounds - the board room - dressed in corporate battle 
attire: the necktie. The irony in Vizenor's screenplay evolves as the racial majority board members get on an old school bus driven by the 'Warriors' to play a softball game; "Anglos" versus "Indians" labeled by their red and white team shirts. The board is resistant at first, but the "Warriors" reinforce Anglo superiority by responding with mock childlike athletic ability, fumbling the ball humorously while an observant eye can catch a glimpse of children playing "cowboys and Indians" in the background. The pep talk given by the lead 'Warrior', Harold Sincere, addresses heavy themes of cultural genocide and historic justification interwoven with humorous anecdotes.

"Playing Ball" is viewed as an "American" pastime that. ironically, is never associated with Native Americans, especially since indigenous American identity and behaviors are 'stuck' in the distant past. The 'Warriors' rectify the display of modernism, playing ball, with the reinforcement of external expectations of perceived Indian-ness - a naming ceremony. Vizenor allows the White actors in the film to "play Indian" through their characters' roles, both literally as a team named the "Indians" - and figuratively, through the authentication of their identity in a "traditional" naming ceremony. Vizenor emphasizes the irony in these scenes by incorporating the grotesque underestimations of Native populations at the time of European encroachment. He asks the viewer to critically consider the national patriotic amnesia that US educational institutions have conditioned them to believe through the use of humorous film dialogue that debunks the Bearing Straight migration theory, defames Columbus as never having discovered anything, and confronts the common belief that all Native Americans are experts on all things commonly perceived to be Native American. Prior to the conclusion of the short film, Vizenor's 'Warriors' go through a laundry list of stereotypes that a particularly squeamish and ignorant board member wants to address 
without overstepping political correctness. The punch line: Indian alcoholism and how they overcame it.

In Harold of Orange, Vizenor reinforces Deloria's claim that there is a common understanding of the emergent humour in Columbus commentary, forced relocation, and attempts at religious assimilation, making it laughable for an in-group audience. Vizenor uses the stereotype to his characters' advantage, highlighting the dominance and omnipresence of ignorance in regards to contemporary indigenous identity. The "Warriors" claim that if the board donates adequate funds to their entrepreneurial coffee plantation it will lead to a "sober revolution on reservations around the world." The irony is maintained throughout - given that dominant culture is so blinded by their belief in antiquated Native stereotypes, and so resistant to acknowledge less static emergent identities and significant outliers of encompassing generalizations - that they are being played the fool by funding such mythical business ventures. Vizenor metaphorically kills outdated notions of indigenous identity with numerous witty fictionalised deaths of Harold Sincere's grandmother throughout the film.

As an "insider" armed with irony and humour, Viznor brilliantly portrays the numerous problematic stereotypes that plague Native Americans. Films targeting contemporary Native Americans cast in normative roles have received little attention in academic circles, as have Forty-nines, a Native American musical tradition. Forty-nines are described as a "social dance for young men and women performed in concentric circles around a group of male singers around a drum or a resonator... always performed in the nighttime, is usually total darkness, and is usually accompanied by heavy drinking by the participants sometimes followed by drunken brawls...Local authorities attempt to prevent forty-nines whenever possible.” (Feder 
1964, 290). This out-group anthropological observation of Forty-nines questions the morality, in relation to western values, of the contemporary tradition describing Forty-nine children being born of "doubtful" parents and speculating on the "loose morality" of the dance and culture (Curtis 1930, 137). Perhaps these externally composed speculations explain why I was only able to locate one publication dedicated to documenting Forty-nines, albeit ethnocentrically, through microfilm and written description. The literature dates back to 1930, though many Indigenous North Americans engage in Forty-nines today.

Forty-nines participants partake in the comical components of freestyle singing by incorporating contemporary mainstream themes like cartoon characters, nursery rhymes, lullabies, and even John Wayne. The singing generally is "off the cuff" with the exception of some favorites that have become popular at powwow circuit after-parties. The Black Lodge Singers drum group commercialised the songs in a series of albums titled Powwow Songs (1995). John Wayne's Teeth (Smith 1998), made popular by the film Smoke Signals (Alexie 1999), questions the legitimacy of John Wayne's teeth with the presupposition that you shouldn't trust someone who you've never seen smile... "John Wayne's teeth, he-ya, John Wayne's teeth, he-ya, are they fake, or are they real? Are they wooden or maybe steel?" (Smith 1998). The jesting at this popular icon of the Wild West not only brings into question whether you should trust a cowboy, but suggests one should reverse the historicised perspective of the cowboy as hero, the Indian as villain.

Though the origin of Forty-nines is unknown, a number of ideas about their origins exist: they emerged when the Native Americans were excluded from drinking establishments during the 1849 Gold Rush; they have their roots in a traditional Pueblo dance that was 
"perverted" by Oklahoma Indians after forced removal; or, they are a nod to the $49^{\text {th }}$ Infantry and the indigenous soldiers who served in US Indian Wars (Feder 1964).

The "doubtful morality" that anthropologists attributed to the postpowwow gatherings judge open sexuality, humorously referred to as "snagging", based on a puritanical ethic that generally was not prevalent among indigenous populations predating western encroachment. Forty-nines defy the patriarchy, nuclear family structure, and sexual conservatism that was forced upon Native Americans through systemic federal assimilation programs. It is a contemporary venue than invites indigenous populations to enjoy selfhood through comical musical interlude. Though, as anthropologists noted back in 1930, local authorities still attempt to prevent Forty-nines whenever possible. Ultimately, Forty-nines are an emergent example of the re-appropriation of old ideas of what is indigenous as they combine traditional hand drumming and vocals with modern lyrics. The virtual exclusion of Forty-nines as legitimate ethnomusicology exemplifies that historical stereotyping and commodification of Native culture has not dissipated.

\section{Conclusion}

Natives are depicted throughout Hollywood as silent and stoic, primitive and unintelligent, or inextricable from Mother Earth (Alexie 1993). Meeks (2006) cites the inclusion of popular stereotypes in TV shows, movies, books, and even messages in greeting cards. She describes these depictions and the associated script as an attempt to eradicate Native Americans from the national landscape, citing historic and economic marginalisation as further support (Meeks 2006, 121). Primary source documents describing colonial Native oratory greatly contradict these stereotypes. 
The prohibition of change and the perpetuation of commodified "imagined Indians" deny Native Americans rights to peoplehood and the civil rights associated therein. Natives are ignored or recreated for historical convenience in textbooks. Individual identities, and culturally diverse tribal communities are replaced with popular acceptance of John Wayne's Hollywood Indians. Natives are "honored" through the idiocy of mimicry clad in mascot. Native characters speak in foreign, childish, broken English.

Natives Americans are a people whose past has been recreated to justify European encroachment, and whose present is determined by media adherence and popular belief of this falsified history. The momentum of societal ignorance of contemporary Native American issues enables injustice to continue in Indian Country. There will be no recognition or reconciliation until negative stereotypes are eradicated and truths are publicised: a feat that Native authors and artists are challenging through the use of humour as a medium for contemporary emergent indigenous identity.

\section{References}

Alexie, S. The Lone Ranger and Tonto Fistfight in Heaven. New York: Atlantic Monthly Press, 1993.

Alexie, S. Toughest Indian in the World The. New York: Atlantic Monthly Press, 2000.

Alexie, S. The Absolutely True Diary of a Part-Time Indian. New York: Little and Company, 2007. Axtel, J. Humor in Ethnohistory. New York: Spring Press, 1990. Black Lodge Singers. Pow wow Songs. Phoenix: Canyon Records, 1995. Bruchac, J. Survival This Way: Interviews with American Indian Poets. Tucson: University of Arizona Press, 1987. 
Cavanagh, S. 'Playing Indian.' Education Week 22 (2003): 1-2.

Chavkin, A. The Chippewa Landscape of Louis Erdrich.

Tuscaloosa: University of Alabama Press, 1999.

Churchill, W. Since Predator Came: Notes from the Struggle for American Indian liberation. Oakland: AK Press, 1995.

Coulombe, J. L. 'The Approximate Size of His Favorite Humor:

Sherman Alexie's Comic Connections and Disconnections in the Lone Ranger and Tonto Fistfight in Heaven.' American Indian Quarterly Winter (2002): 94-115.

Curtis, E. S. The North American Indian New York : Johnson Reprint Corp., 1970.

Deloria, V. Custer Died for your Sins: An Indian Manifesto. London: Macmillan Press, 1969.

Feder, N. 'Origin of the OK Forty-Nine Dance.' Ethnomusicology 8 (1964): 290-294

Fleming, W. 'Getting Past Our Myths and Stereotypes about Native Americans.' Education Digest 72 (2007): 51-57.

Freng, A. 'American Indians in the News: A Media Portrayal in Crime Articles.' American Indian Culture and Research Journal 31 (2007): 21-37.

Gleason, W. 'Her Laugh an Ace: The Function of Humor in Louis Erdrich's Love Medicine.' American Indian Culture and Research Journal 11 (1987): 51-73.

Grassian, D. Understanding Sherman Alexie. Columbia: University of South Carolina Press, 2005.

Harold of Orange. Dir. Richard Weise. Vision Maker Video, 1984. Film.

Hawkins, J. 'Smoke Signals, Sitting Bulls, and Slot Machines: A New Stereotype of Native Americans.' Multicultural Perspectives 7 (2005): 51-54.

Lincoln, K. Indi'n Humor: Bicultural Plan in Native America. New York: University of Oxford Press, 1993. 
Meek, B. 'And the Injun goes 'How!': Representations of American Indian English in White Public Space." Language in Society 35 (2006): 93-128.

Mihesuah, D. American Indians: Stereotypes and Realities. Atlanta: Clarity Press Inc, 1996.

Pewewardy, C. 'Playing Indian at Halftime: The Controversy Over American Indian Mascots, Logos, and Nicknames in Schoolrelated Events.' The Clearing House 77 (2004): 180-185.

Posey, A. L. Fus Fixico Letters. Lincoln: University of Nebraska Press, 1993.

Ryan, A. J. The Trickster Shift. Seattle: University of Washington Press, 1999.

Smith, B. C. Smoke signals: Music from the Miramax Motion Picture. United States: TVT Records, 1998.

Smoke Signals. Dir. Chris Eyre. Shadowcatcher Entertainment, 1999. Film.

Stannard, D. American Holocaust. New York: Oxford University Press, 1992.

Walters, A. L. Ghost Singers. Albuquerque: University of New Mexico Press, 1994.

Wilson, J. The Earth Shall Weep: A History of Native America. New York: Grove Press, 1998.

Womack, C. S. Red on Red: Native American Literary Separatism. Minneapolis: University of Minnesota Press, 1999. 